

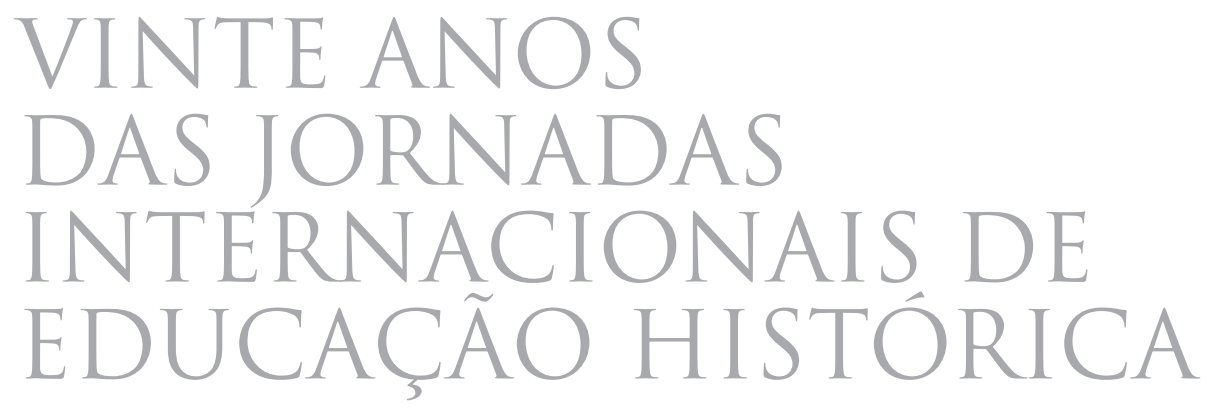

COORD.

LUIIS ALBERTO MARQUES ALVES

MARÍLIA GAGO

MARIANA LAGARTO 
Título: Vinte Anos das Jornadas Internacionais de Educação Histórica

Coordenação: Luís Alberto Marques Alves, Marília Gago, Mariana Lagarto

Design gráfico: Helena Lobo Design | www.hldesign.pt

Imagem da capa: Globo Terrestre. Foto: Marta Sofia Costa (CITCEM).

Composição da imagem da capa de Marta Sofia Costa (CITCEM)

Edição: CITCEM - Centro de Investigação Transdisciplinar Cultura, Espaço e Memória

Via Panorâmica, s/n | 4150-564 Porto | www.citcem.org | citcem@letras.up.pt

ISBN: 978-989-8970-33-6

DOI: https://doi.org/10.21747/9789898970336/vin

Porto, julho de 2021

Este trabalho é financiado por Fundos Nacionais através da FCT - Fundação para a Ciência e a Tecnologia, no âmbito do projeto UIDB/04059/2020. 


\section{SUMÁRIO}

NOTA DE ABERTURA

Marília Gago, Mariana Lagarto

\section{CONTRIBUTOS INTERNACIONAIS}

Hilary Cooper

Percursos dialógicos com Isabel Barca: a crise da transposição didática e a construção da aula histórica

Maria Auxiliadora Schmidt

Educação Histórica: epistemologia, estética e ética

Estevão de Rezende Martins

A aula-oficina como possibilidade de mudança metodológica na forma de ensinar História no Brasil

Marlene Cainelli

Narrativa histórica: uma maneira de ensinar e aprender história sob a perspectiva da Educação Histórica

Rosi Terezinha Ferrarini Gevaerd

A evidência audiovisual mobilizada pela ideia de interculturalidade na aprendizagem histórica dos jovens estudantes portugueses a partir dos vídeos de história no YouTube

Marcelo Fronza

Para conhecer a Educação Histórica: um inventário a partir da teoria da História sobre a Educação Histórica em Portugal

Thiago Augusto Divardim de Oliveira

A aula-oficina e suas possibilidades: vinte anos depois, 1999-2019

Maria da Conceição Silva, Breno Mendes, Cristiano Nicolini

Resignificar la enseñanza y el aprendizaje de la Historia en Colombia. Caminos posibles a partir de la Educación Histórica

Nilson Javier Ibagón Martín

Luís Alberto Marques Alves 
Primeiro estranha-se, depois entranha-se. Alguns olhares sobre apropriações da Educação Histórica em relatórios de formação inicial

Raquel Pereira Henriques

A Educação Histórica em Portugal: percursos formativos e investigativos na Universidade do Minho

Glória Solé

Educação Histórica - diálogos com diversos meios e agentes educativos

Marília Gago, Mariana Lagarto

\section{CONTRIBUTOS DE DOUTORAMENTOS}

Pensamento histórico de crianças, jovens e professores: um olhar interperspetivado acerca da explicação-narrativa histórica

Marília Gago

Na charneira de uma Educação Histórica

Ana Catarina Gomes Lage Ladeira Simão

Educação Histórica e Patrimonial: percursos de investigação

Helena Pinto

Educação Histórica: perspetivas de aprendizagem da história dos alunos de algumas escolas secundárias de Benguela/Angola

Angelina Aguiares Ngungui

Educação Histórica e formação contínua (ou dos professores e das práticas)

Mariana Lagarto 


\title{
NOTA DE ABERTURA
}

\author{
MARÍLIA GAGO \\ MARIANA LAGARTO
}

The reason for teaching history is not that it changes society, but that it changes pupils; it changes what they see in the world, and how they see it... to be historically ignorant is just to be ignorant.

Peter Lee, 1992 e 1984

Reúnem-se neste livro contributos de vários pensadores e investigadores em Educação Histórica, cujo percurso se cruza com o da Professora Isabel Barca, dentro e fora das Jornadas Internacionais de Educação Histórica por si criadas em 2000.

Apesar de a pandemia da covid-19 nos ter trocado as voltas em 2020, aqui estamos em 2021 a assinalar a XX edição destas Jornadas que se tornaram, ao longo de duas décadas, um espaço de debate e partilha de experiências, a nível nacional e internacional, em torno das problemáticas teóricas da História articulando as Epistemologias da História e da Educação, e das práticas do ensino e da aprendizagem em História. Estas partilhas, muitas delas divulgadas através das Atas das Jornadas, constituíram o lastro que permitiu um debate contínuo e interperspetivado, bem como a constituição de uma oferta de formação contínua para os professores que, no terreno educativo, procuravam desenvolver o pensamento histórico e a consciência histórica dos seus estudantes para que estes conseguissem «dar mais sentido(s) e significado(s)» à História e compreendessem a realidade humana de forma(s) mais complexa(s).

Não é de somenos lembrar aqui o contributo de Isabel Barca para a formação doutoral e pós-doutoral em termos nacionais e internacionais contribuindo, de forma marcante, para o desenvolvimento da investigação em Educação Histórica, bem como a investigação desenvolvida sob sua coordenação de dois projetos de investigação pioneiros Hicon: Consciência Histórica - Teoria e Práticas (I e II), financiados pela Fundação para a Ciência e a Tecnologia.

O livro está, por isso, organizado em três áreas que abarcam os contributos internacionais, os nacionais e os contributos de doutoramentos. 


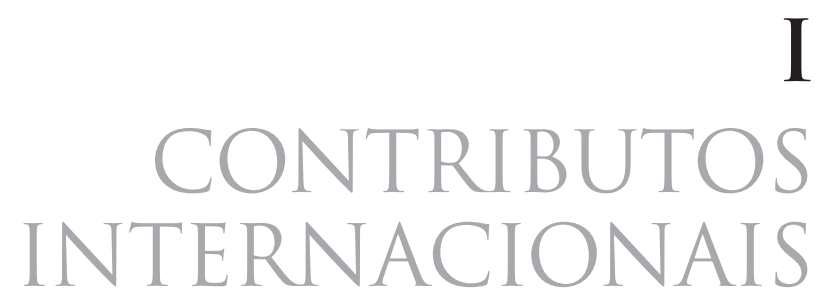





\title{
ISABEL BARCA: A PERSONAL PERSPECTIVE
}

\author{
HILARY COOPER *
}

Isabel Barca has been a constantly recurring leitmotiv, with an important place in my personal narrative. In this chapter I reflect on the many brief and spasmodic but memorable occasions that have punctuated our professional lives, over thirty years.

\section{WHEN I FIRST HEARD OF ISABEL BARCA}

As a history graduate, I taught in primary schools for a number of years, because at the time, this was far more intellectually innovative than teaching history in secondary schools. But by the mid-1980s I realised that exciting new ideas were emerging, re-thinking the purpose and nature of history in schools. These began with pamphlets by Jeanette Coltham and John Fines ${ }^{1}$ and Peter Rogers ${ }^{2}$ and the Schools History Project for 13-16-year-olds, which was set up in 1972. While continuing to teach I decided, in the late 1980s, to embark on my own doctoral research into Young Children's Thinking in History ${ }^{3}$. My supervisor at London University Institute of Education was Peter Lee. Researching pedagogy in history was unusual at the time, but when I met Peter after a summer vacation, he was very excited. He told me that he had been speaking about new approaches to history education at a conference in Portugal and to his amazement someone had responded in a very lively and enthusiastic way and asked him to supervise her $\mathrm{PhD}$. in this innovative new area. Her name, he said, was Isabel Barca.

\section{WHEN I FIRST MET ISABEL}

In 2004, when I was working at the University of Lancaster, I thought that it would be a good idea to organize a conference on History Education and Society at our Education Department in the small town of Ambleside, in the north-west of England. Dr. Jon Nichol, a colleague at the University of Exeter, said he would like to join me in this enterprise. We called our conference the History Educators Research Network. To our great surprise thirty-four participants, coming from every continent, presented papers at the conference. And to my amazement, a paper was submitted, on «Ideas on History and Orientation in Time: a study with beginning teachers» by someone from the Instituto de Educação e Psicologia, in the Universidade do Minho, Braga, Portugal.

\footnotetext{
* Emeritus Professor, University of Cumbria, England.

${ }^{1}$ COLTHAM \& FINES, 1971.

${ }^{2}$ ROGERS, 1979.

${ }^{3}$ COOPER, 1991.
} 
She was Isabel Barca. I was intrigued to be meeting with Isabel Barca and asked Peter Lee, "What is she like?» After consideration Peter replied, diplomatically, «very petite».

So I was not surprised when, on the first day of the conference a «very petite», smiling and dynamic lady with waist-length blond hair came towards me and embraced me. I was surprised, however, when she introduced the lively group of colleagues she had brought with her: Júlia Castro also from the Universidade do Minho and Olga Magalhães from the Universidade de Évora in Portugal, who were co-authors of her paper. I was even more impressed when Isabel introduced me to Tânia Braga Garcia and Maria Auxiliadora Schmidt from the Universidade do Paraná, in Curitiba, Brazil.

Maria Auxiliadora Schmidt and Tânia Braga Garcia told me about the research they had done for the paper they were presenting on «Teaching History, Based on Documents from the Family Archives: a social experiment with Brazilian Children». I still have the two published books resulting from the project, which Maria Auxiliadora presented me with. She had rehearsed a little speech for when she met me, saying, in halting English, «I did not know you would be such a sweet person». This ensured a long friendship with Isabel, Maria and their many colleagues!

It was a friendship which grew as we continued to meet regularly, through the following History Education International Research Network (HEIRNET) conferences, which Jon Nichol and I have organized annually since 2005.

Whenever I arrive at a HEIRNET Conference it is not long before I see a waving hand and laughing faces followed by hugs and kisses with Isabel and her surrounding group of colleagues and we are excitedly catching up with news and anecdotes about the previous year.

Isabel hosted the HEIRNET conference at the University of Minho in 2011 and Maria Auxiliadora hosted the conference at the Universidade do Paraná in 2012.

\section{ISABEL'S HEIRNET CONFERENCE AT THE UNIVERSIDADE DO MINHO}

The HEIRNET conference in 2011 was hosted by Isabel, at the University of Minho. I have vivid memories of the amazing Grande Hotel Bom Jesus, where I had decided to stay. This was, perhaps, not the most convenient hotel for the University, so Isabel and her students arranged daily transport for me. I vividly remember the Stations of the Cross leading up 116 meters to the hotel and the Bom Jesus do Monte Cathedral, where Peter Lee had advised me to search for the remains of a long deceased cardinal. I found it! I also remember going with Helena Pinto on a conference tour of the ancient buildings of Guimarães, the subject of her doctoral research. 


\section{MARIA AUXILIADORA'S HEIRNET CONFERENCE AT THE UNIVERSIDADE DO PARANÁ}

The following year I met Isabel at the HEIRNET conference in the University of Paraná, in Curitiba, Brazil, hosted by Isabel's friend, whom I had first met in Ambleside and was now also my friend, Maria Auxiliadora Schmidt. I remember Isabel coming into my hotel while I was finishing my breakfast and dragging me out in a hurry, explaining that everyone was waiting for me to open the conference. I had memorised a little speech in Portuguese and was trying desperately to remember it as we crossed the road. Isabel presented a paper, with Júlia Castro, Helena Pinto and Graça Sanches about identity and inter-culturality in history education, comparing the ideas of Cape Verdean and Portuguese students. That conference was memorable for so many reasons. I remember Isabel pulling me onto a table with her in Curitiba market place to dance, against my inclination as I do not dance... I think I was supposed to be one of the Three Graces. However since the eminent Professor, Jörn Rüsen, was already on his feet I was in good company. I remember the visit to the Atlantic Forest to drink cane sugar and to a restaurant in Morretes - where Helena Pinto had a bowl of barreado turned upside-down over her head to demonstrate its solid texture. Oh - and we had been looking forward to bikinis and beaches - it was July — but due to a freak weather condition, the temperature was $-3^{\circ} \mathrm{C}$. I gave my presentation wearing a coat and a hotel blanket. Great fun!

\section{ISABEL'S RESEARCH}

Unfortunately I cannot read Portuguese so I cannot do justice to an appreciation of Isabel's overall research output but an overview of her presentations at HEIRNET over the years clearly reflects three characteristics: wide-ranging research interests, benefitting a variety of groups of people, by making theory/practice links and supporting colleagues.

\section{Wide-ranging research interests}

The common theme that runs through a number of Isabel's presentations is the importance of interpretations of the past, how they eliminate the idea of an imposed fixed view of the past and how relevant this is to personal identity. And for Isabel this is not just an academic notion, to be acknowledged in the process of historical enquiry. It is relevant and personal to students' understanding of the past. Indigenous Portuguese students construct their own narratives of their national past. Immigrants to Portugal may have different perspectives. What ideas do students construct about the African to Brazil slave trade? How is Arab history conveyed in textbooks? How do primary school children in Angola think about the past? It is generally thought that school history should 
have a global dimension, that it should engage children and that it should be relevant to their lives. Isabel's research makes the concept of interpretations intercultural, engaging and relevant. It examines the ways in which people construct history.

Isabel's presentations at HEIRNET conferences reflect the variety of her research questions. In 2005 she spoke about «History and Orientation in Time», in London, in 2006, she described researching "How Children Make Sense of Historic Streets» and in Istanbul in 2007 she was researching «Identities in History». In Northern Ireland (2009) she told us about «Portuguese Students' accounts of Different versions of the Past» and in New York in 2010 she presented a challenging model of history education. At the Ljubljana HEIRNET she focused on «Arab history in Portuguese Text Books» and London, in 2015, she was talking about time orientation again, this time comparing the views of Portuguese students with those of Portuguese-speaking students in Brazil. HEIRNET was in Murcia in 2016, and Isabel presented research on «Portuguese Students Voices about their National Contemporary Past». The next year in Dublin she spoke about a study with Portuguese students about «Constructing ideas about slavery and the slave traffic from Africa to Brazil». In Corfu she told us how immigrant families in Portugal understand their history and in 2018 conference in Vienna she spoke about the local perspective of history education in a school in Angola. Isabel's HEIRNET research papers reflect both a wide variety of questions, about time, local and national history, identities, interpretations, including those involving slavery and immigration. They also embrace diverse geographical areas: Hispanic countries, Arab history, slavery from Africa to Brazil and Angola.

\section{Benefits of Theory/Practice Links}

Isabel's research and the research she has supervised is also relevant because it is undertaken, sometimes with student teachers, sometimes with practising teachers and sometimes with school pupils. It involves students in exploring their own thinking in order to understand how this may be applied to school students both inside and outside the classroom. And it explores teachers' practice, not only by helping them to reflect on their practice but also to consider how, in the light of these reflections, to develop and improve their practice so there is little doubt that it has impact.

The research in Isabel presents at HEIRNET is not esoteric but is of practical benefit to different constituencies. For example, the 2005, 2007, 2009 and 2016 papers inform teacher educators about the thinking of student teachers, the 2006 paper supports teachers in planning effective local history for their pupils. Isabel's 2014 paper enables teachers to evaluate the textbooks they use with children and the children who will ultimately be the most important beneficiaries live not only in the Iberian Peninsula, but also in South America, Africa - and anywhere penetrated by the world of HEIRNET! 


\section{Supporting colleagues}

There are many people who are grateful to Isabel for introducing them to research in history education at Masters and Doctoral level and who went on themselves to be members of the research community. And beyond introducing them to the idea of research she supervised them with enthusiasm, understanding and genuine support. And when they had been awarded their doctorates she worked alongside them, researching collaboratively with them.

Isabel researches collaboratively, sharing research presentations and introducing colleagues to presenting at conferences. For example «How Children Make Sense of Historic Streets; walking through downtown Guimarães» was an aspect of Helena Pinto's doctoral study. Helena in turn presented papers in Dublin in 2017, with Ana Isabel Ponce and Jorge Ortuño and with Alex Ibáñez. She also presented research with Mariana Lagarto, another of her successful doctoral students, whose research on the impact of interventions in history lessons enhanced the practice of participant teachers. In Dublin Isabel presented research done with Ana Paula Squinelo and Glória Solé.

\section{ISABEL'S CONTRIBUTION TO HEIRNET Networking}

Over fifteen years Isabel's dynamic presence contributed to the friendly ethos of HEIRNET conferences. Her sense of style and sense of fun was much appreciated.

I remember an incident she told us about in Istanbul when she marched her colleagues into what she thought was a ladies' tea garden - but it turned out to be something quite different. Isabel introduced many supportive colleagues to HEIRNET. This strengthened the intercontinental growth and status of the history education research community and the development of multi-perspectival and disciplinary approaches to history education.

\section{MY EXPERIENCE OF A JORNADAS}

Isabel clearly did not sit in her office doing and supervising research. She established a series of annual conferences on history education, at the University of Minho. I became aware of this when I was invited to speak at the fourth Jornadas Internacionais de Educação Histórica in 2004. The structure was four guests speaking about their research on aspects of historical enquiry, followed by ten speakers from the University on pedagogical supervision, translating theory into practice in the classroom and the relevance of historical thinking to society. Again this reflects the ways in which Isabel involved students and colleagues and made connections between theory, teaching, school-based work and its significance for wider society. 


\section{PROFESSORSHIP}

So it was not surprising that, in 2010(?), Isabel applied for a professorship at the University of Minho. For me, becoming a professor had simply involved an interview with the Pro Vice Chancellor of my university, who convened a meeting of Professors from other institutions to discuss my Curriculum Vitae and decide whether to offer me a chair. He contacted me on his mobile the following day to ask me what professorial title I should like. I was later feted at my inaugural lecture and everyone attending was given a splendid tea.

I found, to my surprise, I was invited to be one of the three professors who were to conduct the «assessment» of Isabel's application. I discovered that in Portugal, as I think is usual in Europe, this is a public, formal and intimidating affair. I met Isabel's colleagues for lunch, before being taken to an enormously impressive and ancient building. I think it was a part of the Bishops' Palace. First I had to confer with my fellow professors, one from Spain and one from Catalonia. To be honest I am not sure that the concept of constructivist approaches in history education were, at that time, as well-established in the Iberian Peninsula as they have become since. There was a language barrier, of course, but I was not sure that the other judges shared my views.

We were then taken to sit on a platform at the end of a large hall, where an expectant audience was gathered. Isabel was seated at a lectern, which was, if I recollect correctly, on a much lower level, than the judges' platform, facing partly towards the audience and partly to the judges. She had to give a presentation, which each «judge» had to then question her about and she had to defend. I don't know how Isabel felt but I found it stressful! Anyhow, with her usual cool and charm she performed brilliantly. Yet I feared, when we returned to sit in a room with a large round table, to discuss the outcome of Isabel's performance, that there might be a prolonged discussion. But we all immediately agreed to recommend a professorship. They do make you earn your Chair in Portugal! Afterwards I met Isabel and her friends in a nearby café and Isabel introduced me to her delightful grandson, who was then about nine years old.

\section{A FITTING CONCLUSION}

As a Professor, Isabel's work has continued to flourish. On December 1st 2019 she sent me an email, in which she said that the Jornadas «has become a considerably relevant event in the Portuguese-speaking world and it is spreading now among the Ibero-American countries». Well, Isabel, you have played a big part in making this a reality. In this email, as a member of the organizing committee, Isabel also invited me to be a keynote speaker in the 2020 Jornadas in Porto, which will be focused on learning and research in history education. I think that endorses the significant and enthusiastic part that Isabel has played in constantly finding ways in which we can think more deeply 
about the role of history education in all societies, how young people, at different ages can actively engage with the past and how we as educators can help them to do so in ways that are interesting and enjoyable.

\section{BIBLIOGRAPHY}

COLTHAM, Jeanette B.; FINES, John (1971) - Educational Objectives for the Study of History. London: The Historical Association.

COOPER, Hilary (1991) - Young Children's Thinking in History. London: London University Institute of Education. PhD Thesis. Available at <https://discovery.ucl.ac.uk/id/eprint/10019081/7/Cooper,\%20 Hilary\%20Jacquelyn_Redacted.pdf>.

ROGERS, P. (1979) - New History: theory into practice. London: The Historical Association.

SCHOOLS HISTORY PROJECT (SHP). Available at <hoddereducation.co.uk $>$. 



\title{
PERCURSOS DIALÓGICOS COM ISABEL BARCA: A CRISE DA TRANSPOSIÇÃO DIDÁTICA E A CONSTRUÇÃO DA AULA HISTÓRICA
}

\author{
MARIA AUXILIADORA SCHMIDT*
}

\begin{abstract}
Resumo: O trabalho sistematiza um diálogo realizado com a obra da pesquisadora portuguesa Isabel Barca, desde 2001, tendo como referência as sistematizações contidas em seu livro O pensamento histórico dos jovens ${ }^{1}$, no qual pode ser encontrada uma sistematização em oposição às pesquisas de base piagetiana acerca da aprendizagem histórica, como os estudos de Hallam. Ao mesmo tempo em que ela aponta discussões acerca da influência das teorias psicológicas na pesquisa sobre aprendizagem histórica, Isabel Barca mostra caminhos para diálogos com autores que propõem novas aproximações e referências para pesquisas em Educação Histórica, especialmente do Reino Unido, Canadá e Estados Unidos. Está claro que uma nova concepção de aprendizagem histórica estava sendo construída e sua especificidade era ser situada na própria ciência da História. Assim, os diálogos iniciados com Isabel Barca e autores no campo da Educação Histórica, assim como com o filósofo e historiador Jörn Rüsen, puseram em questão o conceito de "Transposição Didática» como um guia para a metodologia do ensino de História. Entretanto, se o problema não passava pelo conceito de «transposição didática», quais seriam os parâmetros de inovação na relação entre ensino e aprendizagem da História? As questões suscitadas provocaram um ruído com os conceitos de aprendizagem histórica que, até então, constituíam os fundamentos da «transposição didática». Ao mesmo tempo, impuseram uma mudança no pensamento acerca da didática da história em contraponto à transposição didática, com a possibilidade do professor investigador e da proposição da «Aula Histórica».
\end{abstract}

Palavras-chave: Didática da História; Transposição didática; Ensino de História; Isabel Barca; Educação histórica.

Abstract: The work systematizes a dialogue carried out with the work of the Portuguese researcher Isabel Barca, since 2001, having as reference the reflections contained in her book The historical thought of young people ${ }^{2}$, in which a systematization can be found in opposition to research on Piagetian-based historical learning, such as Hallam's studies. At the same time that she pointed out discussions about the influence of psychological theories in research on historical learning, Isabel Barca showed paths for dialogues with authors who proposed new approaches and references for research in Historical Education, especially authors from the United Kingdom, Canada and the United States. It was clear that a new conception of historical learning was being constructed and its specificity was to be situated in the science of history itself. Thus, the dialogues initiated with the work of Isabel Barca and authors in the field of Historical Education, as well as with the work of the historian and philosopher Jörn Rüsen, put into question the «didactic transposition» aspect as a guide for the teaching methodology of History. Furthermore, they raised the problem that, if the path did not pass through the "didactic transposition", what would be the parameters of innovations in the relationship between teaching and learning history? The questions raised brought noises that shook the relationship with the concept of

\footnotetext{
* Professora do Programa de Pós-Graduação em Educação da Universidade Federal do Paraná. Coordenadora do Laboratório de Educação Histórica-LAPEDUH/PPGE/UFPR. Bolsista CNPq. E-mail: dolinha08@uol.com.br.

${ }^{1}$ BARCA, 2000.

${ }^{2}$ BARCA, 2000.
} 
historical learning and with the method of teaching History, which, until then, constituted the foundations of the paths suggested by the didactic transposition proposal. At the same time, they imposed the challenge of thinking about the didactics of History beyond the perspective of didactic transposition, with the possibility of the investigating professor and the construction of the "historical class».

Keywords: History didactic; Didactic transposition; Teaching History; Isabel Barca; History education.

Em um número da revista «Propuesta Educativa» (1992), foi publicada uma tradução, em espanhol, do texto de Jörn Rüsen - El desarollo de la competencia narrativa en el aprendizaje histórico. Una hipótesis ontogenética relativa a la conciencia moral . $\mathrm{O}$ contato com a obra deste historiador e filósofo se tornou uma referência para as discussões no grupo de pós-graduandos e também nos grupos de professores com os quais trabalhava em projetos de extensão ${ }^{4}$ do Programa de Pós-Graduação em Educação da Universidade Federal do Paraná.

No entanto, foi somente em 2001 que foi realizado um contato com os estudos do campo da Educação Histórica, sobre a «cognição histórica situada», por meio da investigadora portuguesa Isabel Barca. Em seu livro O Pensamento Histórico dos Jovens: Ideias dos Adolescentes acerca da Provisoriedade da Explicação Histórica ${ }^{5}$, pode ser encontrada uma sistematização contraposição às pesquisas sobre aprendizagem histórica de base piagetiana, como os estudos de Hallam.

Ao mesmo tempo em que apontava discussões acerca da influência das teorias psicológicas nas investigações sobre aprendizagem histórica, Isabel Barca mostrava caminhos para diálogos com autores que propunham novas abordagens e referências para as investigações em Educação Histórica, especialmente autores do Reino Unido, Canadá e Estados Unidos.

As investigações apontadas pela autora apresentam duas características que merecem destaque. Uma delas é que as categorias norteadoras para a construção dos instrumentos de pesquisa ancoram-se na própria ciência da História. Trata-se, por exemplo, da análise do pensamento histórico dos alunos a partir do contato com as fontes históricas. A outra característica refere-se ao tipo de pesquisa realizada, predominantemente de cunho qualitativo, utilizando estratégias como questionários e entrevistas.

\footnotetext{
${ }^{3}$ RÜSEN, Jörn (1992) - El desarollo de la competencia narrativa en el aprendizaje histórico. Una hipótesis ontogenética relativa a la conciencia moral. «Propuesta Educativa», ano 4, n. 7 (out.). Buenos Aires: Miño e Davila Editores, p. 27-35. Publicado em inglês no livro Theorizing Historical Consciousness, organizado por Peter Seixas, University of Toronto, 2004. Na publicação em inglês, consta que a primeira publicação do texto foi na revista «History and Memory», vol. 1, n. ${ }^{\circ} 2$ (1989), p. 35-60. Em 2010 saiu a primeira versão em português - O desenvolvimento da competência narrativa na aprendizagem histórica: uma hipótese ontogenética relativa à consciência moral. In RÜSEN, Jörn (2010) — Jörn Rüsen e o Ensino de História. Org. M. A. Schmidt, I. Barca, E. R. Martins. Curitiba: Editora da UFPR.

${ }^{4}$ Destaco, aqui, o grupo de professores de História do município de Araucária, que ficou conhecido como Grupo Araucária e se tornou uma referência para projetos de formação continuada de professores. Ver THEOBALD, 2007. ${ }^{5}$ BARCA, 2000.
} 
O acompanhamento de pesquisas realizadas por investigadores portugueses, anglo-saxônicos e alemães permitiu que fossem problematizadas duas questões fundamentais. A primeira, ver de que maneira poderia ser entendida a aprendizagem histórica fora dos paradigmas da psicologia, como a teoria cognitivista. A segunda, entender como elaborar e fundamentar cientificamente investigações que levassem em conta a mudança do paradigma da aprendizagem para a filosofia da história.

Ficou claro que uma nova concepção de aprendizagem histórica estava sendo construída e sua especificidade era ser situada na própria ciência da História. Então, era preciso que se entendesse e sistematizasse o seu conceito e significado. Assim, os diálogos encetados com a obra de Isabel Barca e de autores do campo da Educação Histórica, bem como com a obra do historiador e filósofo Jörn Rüsen, foram colocando em questão a vertente da «transposição didática» como orientação para a metodologia do ensino de História. Ademais, levantaram a problemática de que, se o caminho não passasse pela «transposição didática», quais seriam os parâmetros de inovações na relação ensino e aprendizagem da história?

No ano de 2003, durante seminário proferido no Programa de Pós-Graduação em Educação da Universidade Federal do Paraná, a pesquisadora Isabel Barca apresentou a proposta da «Aula-Oficina» como um dos caminhos que poderiam ser percorridos no processo de inovação metodológica. Referenciada na perspectiva da «mudança conceitual», a proposta seduziu os professores que participavam do seminário, particularmente no sentido de que trazia, além das inovações teórico-metodológicas relacionadas com a cognição histórica, o pressuposto de que o professor (a professora) precisa se formar também como pesquisador(a).

As questões suscitadas trouxeram ruídos que abalaram a relação com o conceito de aprendizagem histórica e com o método de ensino de história que, até então, constituíam os alicerces dos caminhos sugeridos pela proposta da transposição didática. Ao mesmo tempo, elas impuseram o desafio de se pensar a didática da história para além da perspectiva da transposição didática, com a possibilidade do professor investigador e da construção da «aula histórica».

\section{TRANSPOSIÇÃO DIDÁTICA: PROBLEMAS DA NATUREZA DE UM SISTEMA DE ENSINO}

O conceito de transposição didática, sistematizado pelo matemático francês Yves Chevallard, foi amplamente difundido no Brasil na década de 1990, particularmente pela sua edição em língua espanhola, realizada a partir do livro La transposición didáctica. Del saber sabio al saber enseñado ${ }^{6}$. O autor assume a existência de um objeto específico de conhecimento, a que chama de «sistema didático», envolvendo relações entre

\footnotetext{
${ }^{6}$ CHEVALLARD, 2000.
} 
a ciência de referência e o tripé: o professor, o saber ensinado e o aluno, bem como a natureza destas relações.

A característica do sistema didático é ser aberto e não pode ser compreendido sem se levar em conta o que acontece em seu exterior ou entorno, isto é, no meio em que ele é constituído. O pressuposto produz algumas derivações, como: o saber produzido na transposição didática ser exilado de sua origem e separado do seu processo de produção, o que produz uma espécie de naturalização do conhecimento; o fato de o professor ter apenas uma relativa autonomia, pois ele não faz a transposição didática, mas trabalha com ela.

Na França, a produção e publicação da obra de Yves Chevallard ocorreu no contexto de debates e proposições acerca da história e constituição das disciplinas escolares, influenciados pelo «boom» da história cultural e sua repercussão no campo educacional, especialmente nas pesquisas sobre história da educação. Destaca-se o trabalho de André Chervel, quem, ao contrário de Chevallard, conferia aos professores e alunos o principal papel de construção da didática das disciplinas escolares, defendendo também que este processo pode ser considerado igual para todos os tipos de conhecimento.

Contemporâneo e interlocutor de Chevallard, o francês André Chervel, a partir de investigações acerca da história da construção da disciplina relacionada à língua francesa, assumiu posição mais enfática em defesa da contribuição das práticas escolares na recriação dos conteúdos a serem ensinados, das interações com alunos, bem como da criação de novas práticas e metodologias por parte dos professores. Sua principal contribuição é a afirmação que a transposição didática tem início nas próprias escolas que, com sua relativa autonomia, não se submetem às determinações externas, sejam elas quais forem, mas, com elas, interagem e, a partir das interações, são reconstruídas teorias, métodos de ensino e soluções didáticas ${ }^{7}$.

Um dos temas destacados por Isabel Barca no seminário realizado em 2003 foi o conceito do professor como pesquisador, o que significa a defesa do professor como produtor do conhecimento. A perspectiva revela um dos pontos mais críticos do conceito de transposição didática que indica ter o processo de transformação científica e didática que afeta os objetos de conhecimento ser iniciado fora da sala de aula até a sua tradução para a experiência escolar, um percurso que escapa ao controle do ensinante. Segundo este princípio, quando o professor realiza o processo de produção de sua aula, do seu curso, a transposição didática já teve seu início, na instância do sistema de ensino estrito senso, ou «noosfera», ou seja, «la esfera donde se piensa - según modalidades tal vez muy diferentes - el funcionamiento didáctico ${ }^{8}$. Neste aspecto, concorda-se com André

\footnotetext{
${ }^{7}$ CHERVEL, 1998: 193-201.

${ }^{8}$ CHEVALLARD, 2000: 28.
} 
Chervel $^{9}$ quando resgata a importante contribuição das práticas sociais de referência e da criatividade dos professores na construção e na natureza do sistema didático.

A pesquisadora brasileira Ana Maria Monteiro ${ }^{10}$ procura valorizar a especificidade do saber escolar, tendo como referência uma reflexão a partir do conceito de transposição didática, destacando a sua importância para a compreensão dos elementos envolvidos no processo de ensino. A autora se preocupou em analisar como determinados professores mobilizam tipos de saberes, o que pode ser considerado um indicativo para a superação de seu status de reprodutores do conhecimento. Trata-se, segundo Monteiro, de «bons professores» dos quais ela procurou entender o porquê de serem bem sucedidos em suas práticas de ensino.

A problemática da aprendizagem é subvalorizada por Monteiro quando adere ao conceito de transposição didática. Em nota de rodapé no texto publicado em 2003, a autora questiona a tendência predominante nas pesquisas educacionais nos anos 60 e 70, que focalizavam os processos de aprendizagem fundamentados na psicologia e psicogênese como «base para a compreensão e melhor realização dos processos de ensino» ${ }^{11}$. Para Monteiro, uma importante contribuição dos estudos pautados na transposição didática é a mudança para o entendimento de que «o ensino implica um processo com características próprias que precisam ser melhor conhecidas», enfatizando a ideia de que os princípios do ensino não podem derivar do estudo da aprendizagem ${ }^{12}$.

Reforçando a relação intrínseca entre o conceito de transposição didática e a preocupação com os processos de ensino constitutivos das didáticas das disciplinas, Monteiro ${ }^{13}$ explicita sua posição, contestando a ideia de que é fundamental conhecer os processos de aprendizagem, corroborando com posições de autores que defendem que os processos de ensino não podem derivar dos processos de aprendizagem mas, principalmente, do método da ciência de referência.

Em contraposição às interpelações ao conceito de transposição didática que não enfatizam a problemática da aprendizagem, a Educação Histórica defende que o significado e a centralidade da aprendizagem na prática docente é uma problemática que vem sendo enfrentada por educadores em geral e, especialmente, por especialistas na área das Didáticas Específicas, como a Didática da História, concordando com o pressuposto de que, se sabemos como se aprende, podemos saber como se ensina. Assim,

\footnotetext{
${ }^{9}$ CHERVEL, 1998.

${ }^{10}$ MONTEIRO, 2002.

${ }^{11}$ MONTEIRO, 2003: 14.

${ }^{12}$ MONTEIRO, 2003: 14.

${ }^{13}$ MONTEIRO, 2003.
} 
o elemento nuclear da prática docente é a aprendizagem, que resulta da atividade intelectual e prática de quem aprende em relação ao conteúdo ou objeto, realizada junto com os professores e colegas. Portanto, a referência para as atividades de ensino é a aprendizagem do aluno; o como se ensina depende de saber como os indivíduos aprendem ${ }^{14}$.

Defende, assim, a importância da concepção de aprendizagem como ponto de partida e pressuposto orientador do método de ensino da História, bem como a sua complexidade e diversidade de abordagens, tendo em vista a sua relação com a ciência de referência. Se o conceito de transposição didática sugere a relevância dos processos instaurados na construção das relações entre a ciência de referência e o saber escolar, tendo como suposto a discussão do método de ensino e não a especificidade da aprendizagem propriamente histórica, uma mudança de foco implica em se levar em consideração que a aprendizagem histórica pressupõe a interiorização de novas qualidades cognitivas com o objeto que está sendo aprendido. Destaca a especificidade do objeto que está sendo aprendido, não apenas no que diz respeito ao conteúdo, mas também às formas de apreensão pelos alunos e professores, podemos inquerir, por exemplo: que novas qualidades cognitivas são estas? O que orienta a intencionalidade de quem ensina em relação a quem aprende e a de quem aprende em relação a quem ensina?

\section{INDO ALÉM DA TRANSPOSIÇÃO DIDÁTICA: UMA RELAÇÃO COM O CONHECIMENTO PARA A FORMAÇÃO DO PENSAMENTO HISTÓRICO}

Em conferência proferida em 2004 no Brasil, durante o VI Encontro Nacional de Pesquisadores em Ensino de História, Isabel Barca apresenta aos investigadores brasileiros o significado e a concepção da Educação Histórica. Ademais de esclarecer o percurso histórico que deu origem às discussões da área, a autora explicita alguns princípios que revelam a natureza das investigações que vinham sendo realizadas, principalmente pelos pesquisadores do Reino Unido. Entre eles, cabe destacar a importância conferida à relação que os sujeitos estabelecem com o conhecimento histórico e os desafios investigativos e didáticos propostos para se trabalhar esta relação.

Explicita-se, assim, a importância do conhecimento na relação entre a aprendizagem e formação do pensamento histórico, que inclui o desafio de se articular uma metodologia de ensino de história que possa realizar a formação na prática de ensino. De um lado, o desafio requer a explicitação do significado do pensamento histórico e, de outro, o de criar as condições didáticas para a sua concretização na prática, como um caminho em direção à superação da transposição didática.

${ }^{14}$ LIBÂNEO, 2010: 65. 
Uma posição em relação ao que é o pensamento histórico requer, necessariamente, a perspectiva acerca de uma teoria do conhecimento. Isto é, exige escolhas, porque toda interpretação do mundo, toda forma de conhecimento do real está situada (classe, grupos, perspectiva política, interesses materiais, condicionamentos culturais dos sujeitos). Isto significa que se trata de uma leitura em situação do real em que os seres humanos estabelecem vínculos com o real mediados pelos elementos simbólicos, pelas linguagens, no e a partir de um espaço dialógico produzido na e pela interação social, inclusive conflituosa.

Assim, a "práxis» é a categoria fundante desta relação, e não pode ser confundida com uma simples transformação social e política do real, pois implica em: 1 . Interpretação do mundo para além da sua mera transformação; 2. Ir além da simples unidade entre teoria e prática, pois ambas são um mesmo movimento da realidade (algumas vezes inconsciente), cada uma com sua autonomia relativa. Não se trata, no movimento, nem do puro pensamento, nem da pura ação prática e, muitas vezes, esta unidade do movimento é ocultada, por exemplo, pela divisão social do trabalho que vem provocando as tensões relativas ao mundo humano. Trata-se de um modo específico de gerar conhecimento histórico a partir da relação orgânica com a práxis, porque o modo científico específico de gerar conhecimento histórico parte da vida prática e a ela regressa, de modo tal que passa a interferir na vida dos que o realizam (individualmente e coletivamente). Insere-se, neste processo, a produção e formação da consciência histórica, sempre relacionada com a vida prática e, a partir desta relação, explicitando a sua própria natureza.

É a formação do pensamento histórico que possibilita a fundamentação científica e a constituição da credibilidade do conhecimento histórico, seja sobre seu conteúdo experiencial, sua significância e seu sentido. Pelo conteúdo experiencial, articulando as experiências do presente e do passado, quantitativamente e qualitativamente; pela significância, relacionando as experiências com as intenções dos destinatários (o superavit intencional e as intenções do agir); pelo sentido que dá forma à continuidade das intenções do agir no tempo. Uma resposta à pergunta sobre o que tornaria o pensamento histórico mais científico leva, necessariamente, à questão da regularidade metódica do manejo da experiência histórica. Entre seus determinantes estão tornar a relação com a experiência mais expandida e aprofundada, mediada pela relação com o processo de produção do conhecimento histórico (o método da pesquisa); construir a objetivação e transformação do passado de forma metódica, a partir do acervo de observações obtidas sobre os fatos; utilizar a argumentação como base procedimental.

Parte-se do pressuposto de que o manejo da metódica é a adoção das regras que determinam o pensamento histórico. Isto significa o caminho, o itinerário realizado pelo pensamento para obter conhecimento fundamentado, desde o início, a partir da construção da pergunta histórica, até o final, com a apresentação. Sempre em relação à vida prática e tendo como centralidade a produção de sentido. 
Estudos sobre a formação do pensamento histórico e sua relação com o ensino e aprendizagem da História têm ressaltado a importância não só das estratégias cognitivas concernentes aos conceitos epistemológicos da História, mas também em relação à relevância dos conceitos substantivos ou conteúdos históricos propriamente ditos. Importa não só aprender os caminhos percorridos para a produção do conhecimento histórico, mas apreender, de forma dinâmica, os conteúdos da História. Tal processo é imprescindível para a (re)construção da relação presente/passado e a perspectivação do futuro, na perspectiva da história reconstrutiva. Vale lembrar que o trabalho com os conteúdos ou conceitos substantivos da história também deve partir da relação orgânica com a vida prática ou prática social comum a professores e alunos, ressaltando-se o fato de que cada um deles possui uma compreensão diferenciada dos conteúdos da História, tendo em vista sua forma de inserção na prática social.

Sempre ressaltando que a vida prática é o ponto de partida e de chegada do trabalho com a formação do pensamento histórico e a natureza integrada entre elas, com a finalidade da construção de sentido, foram sistematizadas algumas categorias que poderão ser trabalhadas como competências do pensamento histórico e ser constitutivas da orientação dos processos didáticos, tais como organização e planejamento de atividades de ensino e avaliação, na educação histórica.

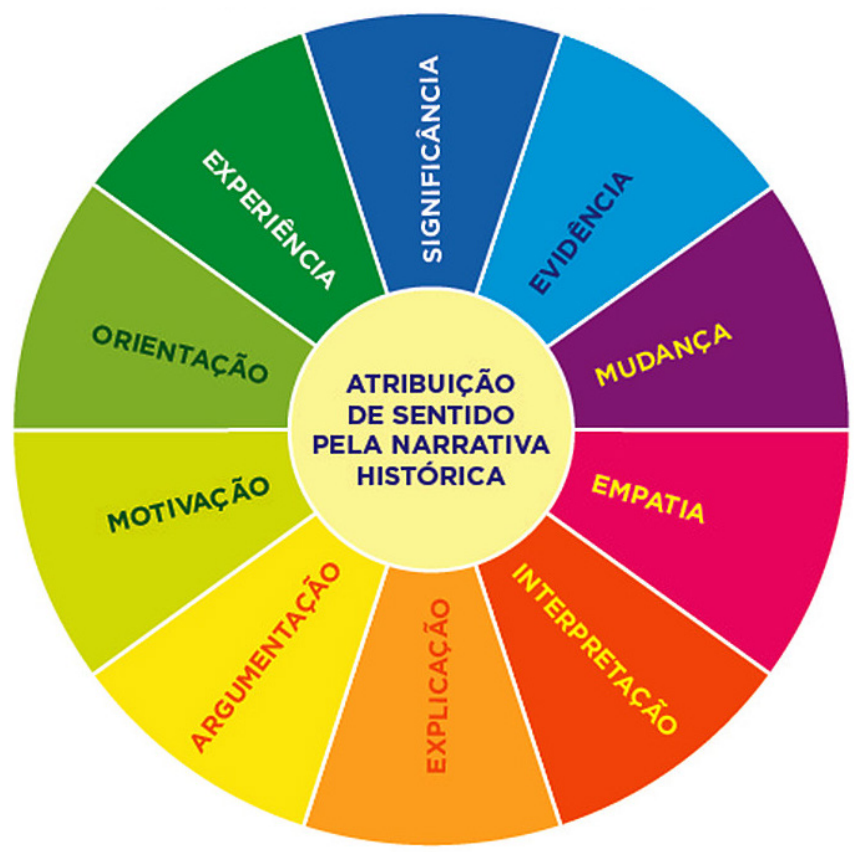

Fig. 1. Matriz: Competências do Pensamento Histórico

Fonte: SEIXAS \& PECK, 2004; LEE, 2005; RÜSEN, 2015. Adaptação: Maria Auxiliadora Schmidt, 2019 
A proposta de uma matriz das competências do pensamento histórico tem como objetivo principal dar referências para o modo de operar da aprendizagem histórica, tendo em vista atingir uma das metas da Didática da História que é construir a competência de atribuição de sentido pela narrativa histórica. $O$ referencial para a análise das categorias propostas é a filosofia e a teoria da História.

Concorda-se com o princípio rüseniano de que «sentido» é o conceito-chave de sua teoria da ciência da história e, portanto, da aprendizagem histórica, que engloba forma, conteúdo e função, e uma concepção de sentido

pode ser definida da seguinte maneira: é um contexto significativo do mundo da experiência e da vida, reflexivo, plausível e confiavelmente controlado. Serve para explicar o mundo, para fornecer orientação, para constituir identidade e para dirigir a ação para um fim. [...] Concepções de sentido consistem, pois, em saberes conectados, em explicações abrangentes do mundo, em determinações normativas do direcionamento e de metas do agir no tempo e no espaço, na unidade entre a explicação do mundo e intenções do agir e, por fim, na formatação da identidade e diferença, de pertencimento e demarcaçãa $o^{15}$.

A centralidade da concepção de sentido na aprendizagem histórica qualifica a perspectiva da «história reconstrutiva» de Jörn Rüsen, em que se busca fazer o passado emergir significativamente do presente. Concorda-se com o autor de que não é uma mera construção do passado (o que pode torná-lo uma «arena de confronto de interesses atuais»), mas uma reconstrução, que significa "pensar o passado como uma cadeia temporal de condições de possibilidades de o homem moldar o mundo e conectar expectativas de futuro a essa cadeia. As experiências do passado tornam-se sempre históricas quando se conectam diretamente, com o sentido e significado, com o presente. Nessa concepção o passado emerge, significativamente, no presente e já não é mais uma imposição de fins, mas uma relação aberta ao futuro» ${ }^{16}$.

Como sugere Barca em sua proposta de "Aula Oficina» ${ }^{17}$, a aula de história não deve e não pode evitar uma participação prévia, com a qual os alunos trazem seus próprios pontos de vista e suas perspectivas da interpretação histórica, pois:

O passado não pode mais ser vinculado, teleologicamente, a um sentido direcionador de sua evolução. Ao revés, cada efetiva evolução concreta deve ser entendida historicamente contra o pano de fundo de múltiplas possibilidades. Com isso,

\footnotetext{
${ }^{15}$ RÜSEN, 2015: 103.

${ }^{16}$ RÜSEN, 2015: 109.

${ }^{17}$ BARCA, 2004.
} 
ao se incluir o espaço de possibilidades na experiência histórica mesma, retira-se dele também seu arbítrio presentista. Uma miríade de histórias se torna possível, baseadas na heterogeneidade das opções atuais do agir. [...] Os processos do passado são interpretados à luz da pergunta acerca das condições de possibilidade sob as quais eles podem ter acontecido, acerca dos elementos prévios dos quais dependem, sem ser por eles determinados ${ }^{18}$.

Trata-se de um princípio metodológico fundamental, o de que ensinar História significa contribuir para que jovens e crianças aprendam narrar a história, de tal forma que, nela e com ela, podem encontrar o reconhecimento, sem o qual não gostariam de ser ou de poder ser. Ademais, quem ensina tem que interiorizar o princípio de que o sentido da história não se reduz a uma autoafirmação compulsiva ou violenta com todas as consequências dolorosas para os envolvidos, mas abre-se a um aumento permanente das experiências temporais que são processadas em um movimento contínuo, entre a experiência da diversidade do outro e a afirmação do eu. Esta abertura da consciência histórica pode ser apreendida pelo fato de os alunos receberem diferentes interpretações da experiência histórica, de modo que eles obtêm sua autonomia por meio de um ato de escolha.

\section{PARA ALÉM DA TRANSPOSIÇÃO DIDÁTICA: A MATRIZ DA "AULA HISTÓRICA" E O PROFESSOR COMO PESQUISADOR}

Outro pressuposto fundamental, assumido no diálogo com a obra de Isabel Barca, foi a perspectiva do professor como investigador social e organizador de atividades problematizadoras, bem como o da superação da aula conferência ${ }^{19}$. Desde a apresentação e discussão dos pressupostos, realizados em 2003, no Seminário de Educação Histórica do Programa de Pós-Graduação da UFPR, foram assumidos desafios de encontrar princípios e caminhos que dessem continuidade aos debates sobre como ensinar a partir dos referenciais da Educação Histórica, o que levou também a um aprofundamento do diálogo com a obra de Jörn Rüsen ${ }^{20}$. Assim, foi a partir da incorporação de sua matriz da ciência da História ${ }^{21}$ e da matriz da Didática da História ${ }^{22}$ que, em trabalho coletivo, foi construída a proposta da matriz da «Aula Histórica».

\footnotetext{
${ }^{18}$ RÜSEN, 2015: 110.

${ }^{19}$ BARCA, 2004.

${ }^{20}$ SCHMIDT, 2017.

${ }^{21}$ MARTINS, 2017

${ }^{22}$ RÜSEN, 2016.
} 


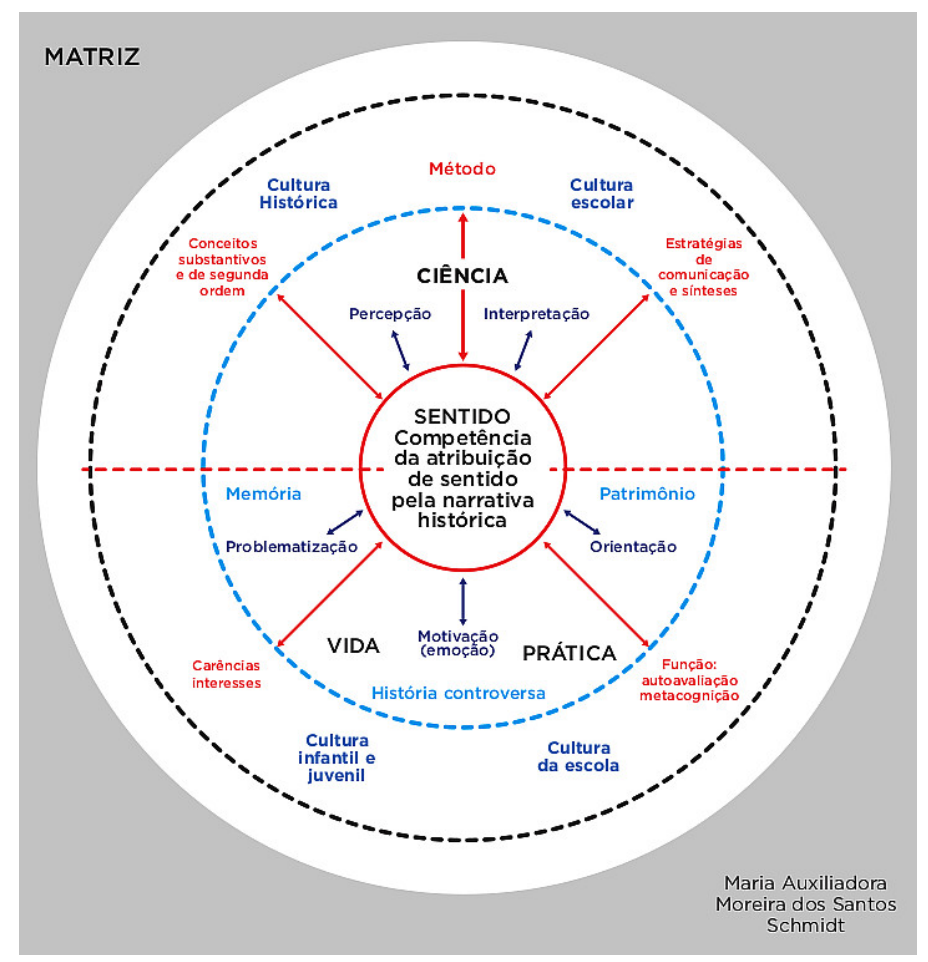

Fig. 2. Matriz da Aula Histórica

Uma das primeiras questões a serem destacadas é a imprescindível relação que se realiza durante o processo de aprendizagem e ensino, entre a ciência e a vida prática, onde estão contextualizados os professores e alunos. Assim, a vida prática é considerada como a origem do processo de aprendizagem, pois é onde se articulam as determinações da prática social e se tornam mais visíveis as tensões entre a cultura histórica e a cultura escolar.

Segundo Julia ${ }^{23}$, a cultura escolar necessita ser apreendida não somente a partir de indícios encontrados em documentos e fontes relacionadas com a organização burocrática da escola, mas também tem que ser procurada nos indícios heterogêneos e mutantes da prática educativa. Para esse autor, de um lado, encontra-se a cultura escolar evidenciada nas normas e textos relativos ao controle do cotidiano escolar, de outro, a multiplicidade das práticas cotidianas. Trata-se do que Rockwell ${ }^{24}$ e Ezpeleta ${ }^{25}$ chamam de a «história documentada» da escola que convive com a «história não documentada»

\footnotetext{
${ }^{23}$ JULIA, 2001.

${ }^{24}$ Elsie Rockwell (Estados Unidos, 1945). Historiadora e antropóloga. Desenvolve seus trabalhos no México. Especialista em pesquisa educacional.

${ }^{25}$ Justa Ezpeleta. Professora honorária da Universidade Nacional da Colômbia.
} 
da escola ${ }^{26}$ e ambas precisam ser olhadas em sua diversidade, sempre na perspectiva da mudança e tomando a escola como uma construção social, ou seja, que cada escola, mesmo imersa num movimento histórico de amplo alcance, é sempre uma versão local e particular desse movimento.

Há que se elevar em consideração o fato de que, apesar de ser comum a professores e alunos, a maneira pela qual cada um vivencia e assume as experiências, demandas e carências especificamente históricas de orientação temporal, presentes na vida prática, não é a mesma. Professores e alunos são agentes diferenciados e com níveis de compreensão diferentes e é a partir deste pressuposto que o caminho em direção à ciência pode ser realizado.

$\mathrm{Na}$ dinâmica do percurso sugerido pela matriz, a partir da prática social são reconhecidas as carências e interesses dos alunos, caminhando em direção ao conhecimento científico, a partir da problematização, pois «a problematização representa o momento do processo em que essa prática social é posta em questão, analisada, interrogada, levando em consideração o conteúdo a ser trabalhado e as exigências sociais de aplicação desse conhecimento» ${ }^{27}$.

Como aponta a Matriz da Aula Histórica, o ponto de partida da formação de sentido é a relação com a práxis, da qual partem as perguntas ou interpelações a serem feitas ao passado, as «perguntas históricas»:

Qué es lo que provoca hacer preguntas históricas? Considero que existen dos posibilidades que impulsan la actividad de formación de sentido en la conciencia histórica por medio de preguntas: a) un movimiento que parte de las experiencias del pasado y (b) un movimiento que parte de las experiencias del presente y conduce a las experiencias del pasado. En la primera modalidad del movimiento, el pasado atrae a causa de su presencia empírica en forma de huellas, monumentos, reliquias, objetos, percepciones sensoriales. El pasado se dirige al ser humano del presente, y esta referencia hace que éste se dirige al pasado preguntando. [...] Otra modalidad de preguntar por el pasado parte del presente. Se trata del fenómeno muy común y posiblemente universal, de la constitución de la conciencia histórica a partir de la experiencia de una ruptura temporal, una divergencia temporal, una discontinuidad, una ruptura de la continuidad de los órdenes vivenciales que estimulan los recuerdos históricos y las formaciones de sentido narrativas. Tal ruptura es un fenómeno del presente ${ }^{28}$.

\footnotetext{
${ }^{26}$ ROCKWELL \& EZPELETA, 2007: 133.

${ }^{27}$ GASPARIN, 2002: 36.

${ }^{28}$ RÜSEN, 2014: 176-177.
} 
Ressalta-se que a relação que o presente assume no processo de aprendizagem histórica vai além do relacionar o conteúdo com o cotidiano dos alunos. Assim, não envolve apenas um aspecto ou estratégia de metodologia de ensino, mas adquire um estatuto orientador da relação com o conhecimento e da opção e seleção de determinados conteúdos e não outros. A relação fundamental com a práxis como ponto de partida e de chegada é também uma opção pedagógica ou um princípio didático-pedagógico.

O processo de consolidação da proposta da Aula Histórica levou em consideração a interdependência horizontal e vertical entre os fatores constitutivos da metódica da História, podendo ser assim explicitados:

1) Tanto quem ensina quanto quem aprende apresentam formas diferenciadas de manifestação da sua consciência histórica, expressando aspectos interculturais do modo como dão sentido à sua experiência do tempo e no tempo. Assim, é fundamental que o ponto de partida do processo de aprendizagem seja o levantamento e categorização das carências e interesses dos agentes, sempre partindo da maneira como cada um deles está inserido na vida prática humana, lembrando que a forma pela qual os professores compreendem a sua inserção na vida prática explicita compreensões diferentes dos alunos. As carências e interesses podem ser investigados, por exemplo, a partir das suas relações com a memória e o patrimônio histórico material e imaterial, o que explica a presença dos referidos elementos na matriz da «Aula Histórica»;

2) A investigação das carências e interesses a partir de perguntas feitas à prática social expressará as carências e interesses dos aprendizes em relação ao tema estudado, levantando possibilidades de trabalho com os conceitos substantivos ou conteúdos da História, bem como com as estratégias cognitivas do pensamento histórico ou conceitos epistemológicos, tais como a interpretação e a orientação. A seleção dos conceitos substantivos e epistemológicos a serem desenvolvidos é sempre um trabalho a ser realizado pelo professor;

3) Considerando os procedimentos adotados pelo historiador na produção do conhecimento histórico, o(a) professor(a) organiza metodologicamente a sua prática docente a partir do trabalho com fontes históricas - primárias e secundárias, problematizando-as e interpelando-as, permitindo às crianças e jovens interpretarem e problematizarem esses vestígios do passado à luz de sua vida prática no presente. A interpelação do passado a partir das fontes tem como ponto de partida as questões ou perguntas suscitadas pelos agentes no contexto de sua vida prática;

4) Após o(a) professor(a) orientar o trabalho da produção do conhecimento histórico, as crianças e jovens, utilizando diferentes linguagens (como histórias em quadrinhos, narrativas escritas etc.), produzem narrativas históricas, não narrativas historiográficas, que expressam as suas consciências históricas a partir 
de interpretações e problematizações que surgem no trabalho com as fontes. Importante ressaltar que a referência às fontes e uso de marcadores temporais podem ser considerados importantes indícios de que as narrativas das crianças e jovens realizam uma reconstrução do passado e têm uma natureza histórica;

5) A avaliação contínua e a sistematização da avaliação, a partir da perspectiva da metacognição (o que os sujeitos sabem acerca do que eles aprenderam), fazem com que as crianças e jovens percebam o seu próprio processo de aprender. A compreensão dos processos mobilizados desde a investigação das carências e dos interesses desses sujeitos até a produção de uma narrativa que expressa sua consciência histórica permite que as crianças e os jovens tomem consciência dos seus processos cognitivos, atribuindo significados e conferindo sentidos ao que aprenderam $^{29}$.

As possibilidades sugeridas na e pela Matriz levaram à denominação de «Aula Histórica» porque permite que os sujeitos envolvidos na relação ensino e aprendizagem realizem, em aulas, seja onde elas se realizem (museus, salas de aulas), o processo metódico da produção do conhecimento histórico, pois:

A aula de História é o momento em que, ciente do conhecimento que possui, o professor pode oferecer a seu aluno a apropriação do conhecimento histórico existente, através de um esforço e de uma atividade com a qual ele retome a atividade que edificou esse conhecimento. É também o espaço onde um embate é travado diante do próprio saber: de um lado, a necessidade do professor ser o produtor do saber, de ser partícipe da produção do conhecimento histórico, de contribuir pessoalmente. De outro, a opção de tornar-se apenas um eco do que os outros já disseram ${ }^{30}$.

\section{CONSIDERAÇÕES FINAIS}

O diálogo com os trabalhos da pesquisadora portuguesa Isabel Barca tem contribuído, de forma sistemática, desde o início do século XXI, para a construção de referências fundamentais para a tradição de pesquisas e debates que foram instituídos no âmbito do Laboratório de Pesquisas em Educação Histórica - LAPEDUH, da Universidade Federal do Paraná. Neste sentido e acompanhando uma tradição das pesquisas que vêm sendo realizadas sobre consciência histórica e aprendizagem, pode ser observada uma revolução coperniciana em direção aos referenciais da ciência da História, em detrimento à predominância dos referenciais da psicologia e da pedagogia. Uma das

\footnotetext{
${ }^{29}$ CURITIBA. Secretaria Municipal de Educação, 2016.

${ }^{30}$ SCHMIDT, 1998: 57.
} 
contribuições foi a instalação de uma crise no paradigma da «transposição didática», que vinha sendo utilizado pelo grupo do LAPEDUH.

Pode-se afirmar que se constituiu numa perspectiva dialógica, pois não significou uma adesão do tipo importação de ideias, mas da realização de uma interlocução construtiva, que vem provocando a adesão dos que são comprometidos com uma educação histórica de qualidade, principalmente os professores, sempre.

A crise sinalizou para dois resultados principais. De um lado, a importância de valorizar o professor como o sujeito da produção do conhecimento no âmbito da escolarização, descortinando a possibilidade da superação da clássica divisão do trabalho entre a academia e a escola básica. De outro, a ênfase nas possibilidades de aprendizagem histórica constituída a partir da formação do pensamento propriamente histórico e na atribuição de sentidos para quem ensina e quem aprende. Estes resultados podem contribuir de forma expressiva para uma educação emancipatória e libertária para que a aula de História seja uma relação de interlocutores que constroem sentidos.

No contexto dos trabalhos desenvolvidos pelo Grupo de Educação Histórica do LAPEDUH/UFPR, consta-se, hoje, um conjunto multiperspectivado de temáticas de investigações, que adotam como referencial as contribuições de Isabel Barca. Trata-se de uma adoção dialógica também, porque referencia-se na teoria da consciência histórica, optando para investigações em espaços de escolarização. Assim, pressupôs a ênfase na metodologia qualitativa da investigação educacional, em abordagens antropológicas e/ou sociológicas, não descartando a necessidade de abordagens históricas para se entender a historicidade, por exemplo, da própria ideia de aprendizagem. Sobretudo, porque tem o professor como protagonista de todo o processo.

A adoção desta perspectiva inclui novas problemáticas e novas abordagens de pesquisas no que se refere, principalmente, à análise dos processos, dos produtos e da natureza do ensino e aprendizagem histórica em diferentes sujeitos, bem como os significados e sentidos dados a estes processos. Sobretudo, atribuição de sentidos que contribuam para uma luta de resistência e da não desistência de um amanhã que perseguimos, com esperança.

\section{BIBLIOGRAFIA}

BARCA, Isabel (2000) - O Pensamento Histórico dos Jovens: Ideias dos Adolescentes acerca da Provisoriedade da Explicação Histórica. Braga: CEEP/Universidade do Minho.

(2001) - Concepções de adolescentes sobre múltiplas explicações em História. In BARCA, Isabel, org. - Perspectivas em Educação Histórica. Actas das Primeiras Jornadas Internacionais de Educação Histórica. Braga: CEEP/Universidade do Minho, p. 29-45.

(2004) - Aula Oficina: do Projecto à Avaliação. In BARCA, Isabel, org. - Para uma Educação Histórica com Qualidade: Actas das IV Jornadas Internacionais de Educação Histórica. Braga: CIEd/Universidade do Minho; Instituto de Educação e Psicologia/Universidade do Minho, p. 131-144.

(2005) - Educação Histórica: uma nova área de investigação? In NETO, José Miguel Arias, org. Dez anos de pesquisas em ensino de História. VI Encontro Nacional de Pesquisadores de Ensino de História. Londrina: AtritoArt, p. 15-25. 
CHERVEL, André (1998) - La culture scolaire. Une approche historique. Paris: Belin.

CHEVALLARD, Yves (2000) - La transposición didáctica. Del saber sabio al saber enseñado. Buenos Aires: Aique.

CURITIBA. Secretaria Municipal de Educação (2016) — Diretrizes Curriculares do Ensino Fundamental — História. Proposta.

GASPARIN, João Luiz (2002) - Uma didática para a pedagogia histórico-crítica. Campinas: Editora Autores Associados.

JULIA, Dominique (2001) - A cultura escolar como objeto histórico. «Revista Brasileira de História da Educação», n. ${ }^{\circ} 1$ (jan./jun.).

LEE, Peter (2005) - Putting principles into practice: understanding History. In DONOVAN, M. Suzanne; BRANSFORD, John D., eds. - How students learn: History, Mathematics and Science in the classroom. Washington, D. C.: The National Academies Press, p. 31-78.

LIBÂNEO, José Carlos (2010) - A integração entre a didática e a epistemologia das disciplinas: Uma via para a renovação dos conteúdos da Didática. In DALBEN, Ângela et al., org. - Convergências e tensões no campo da formação e do trabalho docente. Didática e formação de professores, trabalho docente. Belo Horizonte: Autêntica, p. 81-104.

MARTINS, E. C. de Rezende (2017) - Teoria e filosofia da História. Contribuições para o ensino de História. Curitiba: W. A. Editores.

MONTEIRO, Ana Maria F. C. (2002) - Ensino de História: entre saberes e práticas. Rio de Janeiro: Pontifícia Universidade Católica do Rio de Janeiro PUC/RJ. Tese de doutorado.

(2003) - A história ensinada: algumas configurações do saber escolar. "História \& Ensino», vol. 9 (out.) p. 37-62. Disponível em <www.uel.br/revistas/uel/index.php/histensino/article/viewFile/12075/10607>. [Consulta realizada em 14/01/2019].

ROCKWELL, Elsie; EZPELETA, Justa (2007) - A escola: relato de um processo inacabado de construção. «Currículo sem Fronteiras», vol. 7, n. ${ }^{\circ} 2$ (jul./dez.), p. 131-147. Disponível em <www.curriculosemfronteiras.org/vol7>.

RÜSEN, Jörn (1992) - El desarollo de la competencia narrativa en el aprendizaje histórico. Una hipótesis ontogenética relativa a la conciencia moral. «Propuesta Educativa», ano 4, n. 7 (out.). Buenos Aires: Miño e Davila Editores, p. 27-35.

RÜSEN, Jörn (2012) - Aprendizagem histórica. Fundamentos e paradigmas. Curitiba: W. A. Editores. (2014) - Tiempo en ruptura. México: Universidad Autónoma Metropolitana. (2015) - Teoria da História. Uma teoria da história como ciência. Curitiba: Editora da UFPR. (2016) - Contribuições para uma teoria da Didática da História. Curitiba: W. A. Editores.

SCHMIDT, Maria Auxiliadora (1998) - A formação do professor de História e o cotidiano da sala de aula. In BITTENCOURT, Circe, org. - O saber histórico na sala de aula. São Paulo: Contexto, p. 54-68. (2017) - Jörn Rüsen e sua contribuição para a Didática da História. «Intelligere: Revista de História Intelectual», vol. 3, p. 13-33.

(2019) - Atribuição de sentido como princípio da aprendizagem histórica: contribuição para a metodologia do ensino de História. Curitiba: Universidade Federal do Paraná. Tese apresentada para professora titular.

SEIXAS, Peter (2015) - A History/Memory Matrix for History Education. «Public History Weekly», vol. 4, n. $^{\circ} 6$.

SEIXAS, Peter; PECK, Carla (2004) - Teaching historical thinking. In SEARS, Alan; WRIGHT, Ian, eds. Challenges and prospects for Canadian Social Studies. Vancouver: Pacific Educational Press, p. 109-117.

THEOBALD, Henrique R. (2007) - A Experiência de Professores com Idéias Históricas: o Caso do "Grupo Araucária». Curitiba: Universidade Federal do Paraná. Dissertação de mestrado. 


\title{
EDUCAÇÃO HISTÓRICA: EPISTEMOLOGIA, ESTÉTIÇA E ÉTICA
}

\author{
ESTEVÃO DE REZENDE MARTINS*
}

\begin{abstract}
Resumo: Educação histórica tornou-se um tópos decisivo na articulação entre História como ciência e a relação entre ensino e aprendizagem de História. Tal articulação se dá em mais de uma circunstância: individual, social, privada, pública e notadamente na escolar, cujo sistema é um componente fundamental e incontornável do Estado moderno. Versa-se aqui sobre a prática do pensamento histórico, sua função na constituição da consciência histórica e o envolvimento de ambos no espaço da cultura histórica enquanto requerem que se conheçam as dimensões epistemológica (conhecimento metodicamente confiável), estética (conhecimento didaticamente expressável, transmissível e apreensível) e ética (conhecimento moralmente responsável).
\end{abstract}

Palavras-chave: Educação histórica; Epistemologia; Estética; Ética.

Abstract: Historical education has become a decisive factor in the articulation between History as science and the relationship between teaching and learning History. Such articulation occurs in more than one circumstance: individual, social, private, public and especially in the school, whose system is a fundamental and unavoidable component of the modern State. This article deals with the practice of historical thinking, its function in the constitution of historical consciousness and their involvement in the space of historical culture while requiring to know the epistemological (methodically reliable knowledge), aesthetic (didactically expressible, transmissible and understandable) and ethical (morally responsible knowledge) issues.

Keywords: History education; Epistemology; Aesthetics; Ethics.

O século 21 abriu-se originalmente como um horizonte de progresso e de ampla distribuição de bem-estar, em escala mundial, no movimento de liberalização política e econômica e de reestruturação democrática, em muitos países, após a queda do Muro de Berlim. Conhecer a História e reconhecer-se nela tornaram-se objetivos ainda mais marcantes, como em épocas de grandes transformações.

O otimismo que envolveu o nascimento do milênio em 2001 sofreu um baque doloroso com os ataques aos Estados Unidos no dia 11 de setembro. O idílio do novo século, com suas esperanças de paz e prosperidade irrestritas, encerrou-se em um banho de sangue, menos de nove meses após a alacridade de janeiro. A consciência de que o mundo perdia sua estabilidade organizacional, calcada na cosmovisão ocidental politicamente democrática e economicamente capitalista, tomou de assalto o planeta e persiste teimosamente na terceira década do milênio. No período transcorrido desde a revolução pacífica dos anos 1990, o século 21 ficou marcado por uma acentuada voragem

\footnotetext{
* Professor titular emérito de Teoria da História e de História Contemporânea da Universidade de Brasília (Brasil); Humboldt fellow (Alemanha). E-mail: echarema@gmail.com.
} 
de dúvidas e incertezas, em cujo atascadeiro aparentemente pouco ou nada consegue firmar pé.

Nos choques que surgem ou que se agravam na cena internacional e nos desencontros das crises econômicas - os desdobramentos da de 1999, que parecia superada; a recaída de 2008, cujos efeitos continuam a pesar fortemente na economia mundial - a perda de referência crítica e de distância reflexiva para lidar com o aparente caos do mundo angustia e preocupa as sociedades como desestabiliza o espaço público. $\mathrm{O}$ anonimato das assim chamadas «redes sociais», a ausência de regulação pública de seu uso e a sensação difusa de que «tudo e qualquer coisa vale», acompanhada da pretensão de impunidade, geram a impressão, amplamente difundida, de que o mundo estaria novamente de ponta-cabeça ${ }^{1}$ e que a modernidade haveria fracassado em consequência de seu sucesso tecnológico ${ }^{2}$. Tudo isso acabou por promover, afinal, mais sensibilidade para com a História e com o conhecimento controlado do passado, sobre cujos fundamentos se explica e constrói o presente tanto quanto se projeta e realiza o futuro.

Assim, perdem fôlego as persistentes tentativas de confinar a História a uma espécie de exercício literário sem compromisso com a realidade, que marcaram a segunda metade do século 20, na medida em que alegorias poéticas ou prosaicas não substituem a crescente percepção de que se faz necessário firmar uma base sólida para o conhecimento histórico da experiência do tempo no mundo. Nesse conhecimento confiável se esteia a cultura e a consciência históricas, no âmbito das quais as sociedades e as pessoas se habilitam a pensar, a decidir e a agir "com conhecimento de causa».

\section{A VALORIZAÇÃO DA HISTÓRIA}

Com efeito, foi no próprio século 20 que se realizou a tripla afirmação do campo da História: como (1) capaz de produzir conhecimento confiável porque (2) dotou-se de sustentação teórica sólida e obteve (3) amplo reconhecimento público. O itinerário da legitimação do conhecimento histórico em seu formato científico, pode-se dizer, foi o desafio e a aventura da historiografia no século 20, por ela respectivamente bem relevado e bem vivida. A epistemologia ganhou seu foro de legitimidade para afiançar a qualidade científica do conhecimento, inclusive da História ${ }^{3}$.

A consciência histórica no século 20 soube, por conseguinte, articular os dois extremos entre os quais oscilou longamente. De um lado, manteve-se a firme ancoragem da pesquisa na base empírica, sem cuja solidez não há matéria investigável sobre a ação humana no tempo. De outro lado, incorporou-se uma prudência analítica razoável contra as certezas fáceis e contra o fiar-se precipitadamente nas aparências. A teoria do ato cognitivo na produção historiográfica consagrou, pois, a segurança do empirismo clássico,

\footnotetext{
${ }^{1}$ HILL, 1972.

${ }^{2}$ TOURAINE, 1993; PEREZ, 2010.

${ }^{3}$ MARTINS, 2011: 945-985.
} 
mitigada com a provisoriedade ínsita ao conhecimento que depende da variedade das fontes e da mutabilidade das circunstâncias pessoais e sociais dos historiadores e de seus coetâneos. Ou seja: nem a informação é canônica por simplesmente estar presente em alguma fonte, nem a certeza é uma mera questão de subjetividade particular ${ }^{4}$.

Duas estratégias de percepção e de experiência da realidade são seguidas, por conseguinte, no pensamento histórico e na historiografia. A primeira, que se pode chamar de originária, é a pesquisa direta da empiria - o investigar, definir, identificar, delimitar, localizar, enfim, constatar ou afirmar isso ou aquilo aconteceu, chamando-o «fato» (feito, ocorrido, dado, efetivado, operado, realizado - os particípios se equivalem). Inobstante o grau de complexidade do que se considere como fato, a experiência originária do passado, para o historiador, é irrevogavelmente mediada pelas fontes e nas fontes. Essas fontes alimentam a vasta rede de fatores em cujo entrecruzamento, definido (constatado, situado, evidenciado, descrito) pelo historiador mesmo, se deu o fato. Um e outro acontecimento não se esgotam em si, pela simples constatação mediada, mas põem a necessidade de contextualização, de que depende a compreensão, a explicação e a apresentação do fato.

A segunda estratégia decorre da inevitabilidade da mediação representada pelas fontes originárias. Para a teoria da História, a fonte mesma é, por definição, mediata. A matéria-prima da teoria da História é a práxis dos historiadores, cristalizada no tempo sob a forma de historiografia. Tem-se, pois, duas mediações interdependentes, que representam um duplo filtro com relação à experiência do passado. $\mathrm{O}$ caráter mediado da experiência histórica como prática metódica da história como ciência é, pois, inerente à sua natureza própria. Como o tempo presente e suas indagações são igualmente formas de mediação da pergunta que o historiador põe ao passado, como ponto de partida de sua investigação atual, assim pode-se sem dúvida imaginar que o respectivo tempo presente do registro das fontes é uma mediação com a cor da época e dos interesses do registrador. A produção metodizada de conhecimento histórico se dá no âmbito da História como ciência, e se expressa na historiografia. Mesmo que esse conhecimento seja gnosiologicamente garantido e epistemologicamente sustentado, nele não se esgota, contudo, o conhecer historicamente. O ensinar-aprender de si e sobre si, no contexto de dada sociedade e dada cultura, pertence substantivamente ao modo humano de ser: "A centralidade da relação a si próprio, formadora da identidade, deve incluir sua qualidade humana, partilhada com todos os outros ${ }^{5} . » A$ vida prática, à qual pertence a experiência de ver e aprender, é um processo educacional pessoal e social permanente. Educar e educar-se historicamente também ${ }^{6}$. São incontáveis as formas de exprimir o que se aprendeu ao viver no tempo, o que se entendeu ao transformar em história a

\footnotetext{
${ }^{4}$ MARTINS, 2017: 37-59.

${ }^{5}$ RÜSEN, 2015: 270.

${ }^{6}$ MARTINS, 2017: 277-298.
} 
vivência temporal empírica, pela reflexão. A forma mais frequente está na narrativa, oral ou escrita, seja em que formato for. A formatação do modus exponendi do conhecimento histórico caracteriza a dimensão estética do entendimento expresso. Conhecimento confiável e controlável, conhecimento entendido e compartilhado, conhecimento aprendido e ensinado constituem o cerne da relação pessoal e social da educação histórica.

\section{EDUCAÇÃO HISTÓRICA}

Educação histórica tornou-se, por conseguinte, um tópos de atualidade crescente ${ }^{7}$. Sua prática, entretanto, se dá também em um contexto social no qual prevalece a educação formal em escolas. Desde a instauração da obrigatoriedade da instrução pública, no sistema educacional instituído, mantido ou patrocinado pelo Estado, os componentes da formação intelectual do aluno constituem objeto de projetos, públicos e privados, de todos os tipos ${ }^{8}$. A obrigatoriedade de ir à escola, sob patrocínio e coerção do Estado, começa com o estatuto prussiano de 1763 e gradualmente se espalha por praticamente todo o hemisfério ocidental até sua virtual universalização no século 20. Entende-se, assim, a preeminência alcançada pela reflexão sobre ensino e aprendizado de História, bem como sobre a relação social com o sistema escolar e com sua intrincada rede de regulamentos quanto à formação de docentes, conteúdos a aprender e a ensinar, táticas de transmissão e interação em classe, uso de fontes e de manuais.

A expressão «educação histórica», forjada e amplamente utilizada no universo de língua inglesa, possui uma abrangência maior do que as expressões, entrementes também usuais, de: ensino da História, didática da História, didática de Ciências Sociais, e semelhantes, correntes em alemão, português, espanhol ou italiano.

O Instituto de Educação do University College London foi o centro de irradiação da concepção de "educação histórica», no âmbito e para além de seu departamento de Currículo, Pedagogia e Avaliação. Essa expressão consagrou-se como uma espécie de categoria genérica, em cuja área de cobertura se situam as diversas formas de fazer, aprender e ensinar história.

Investigadores e centros de pesquisa de grande alcance em muitos países ecoam e potencializam as diversas dimensões da educação histórica, em torno de alguns conceitos-chave. São categorias-mestras da educação histórica: pensamento histórico, consciência histórica, cultura histórica. Há por certo um bom grau de interdisciplinaridade, na prática do aprendizado e do ensino de História, com a filosofia, com a pedagogia, com a História como ciência.

Assim, na reflexão sobre o sentido e a fundamentação da «educação histórica» cabe ter presentes duas dimensões empíricas e duas metadimensões analíticas. As duas

\footnotetext{
${ }^{7}$ URBAN et al., org., 2018.

${ }^{8}$ AUBRY et al., coord., 2015.
} 
dimensões empíricas são: (a) o ensino/aprendizagem de História no âmbito instrucional dos sistemas escolares e (b) o ensino/aprendizagem de História no espaço sociocultural de qualquer pessoa (escolarizada ou não) em que o domínio reflexivo da experiência subjetiva no fluxo do tempo é uma prática comum. As duas metadimensões analíticas são: (a) a relação do ensino/aprendizagem com sua fonte material e formal: a História pesquisada, interpretada e explicada na historiografia e (b) a relação ensino/aprendizagem como circunstância cultural que envolve todo agente racional humano no seu espaço vital.

Para quê e porquê se promove «educação histórica»? Contar e recontar a história é sem dúvida uma tarefa multidimensional, moldada por um sem-número de perspectivas e objetivos, complexa em si mesma e complexa por surgir e praticar-se em um meio social e cultural inelutavelmente pleno de história. Esse contar varia, obviamente, de acordo com a idade e o gênero do narrador, com seu contexto socioeconômico e cultural. A variação narrativa posta, reposta e contraposta na educação histórica é uma realidade empírica da história mesma, vivida e praticada pelas pessoas.

A História, em que toda e qualquer sociedade está imersa, se exprime na cultura na qual seus integrantes se forjam e em cujo contexto atuam. Tal assertiva é genérica. As sociedades no século 21 vivem de forma praticamente universal em organizações estatais, nas quais entrar para o sistema escolar obrigatório e seguir nele por um período entre 10 e 15 anos é uma meta declarada, uma política pública e quase sempre uma imposição legal. É, pois, no meio do sistema escolar que o tema da educação histórica surgiu e se desenvolveu. Substancial parte das publicações que versam sobre esse assunto concentra-se nos procedimentos de ensino e aprendizagem em ambiente escolar e mais raramente em outros contextos (como, por exemplo, museus e exposições) ${ }^{9}$.

Educação histórica não se restringe, contudo, ao sistema escolar nem se esgota nele. A reflexão sobre a experiência existencial no tempo, em que consiste o núcleo originário do pensamento histórico, faz da História uma instância incontornável para a forma mesma de ser humano. Experiência, entendimento e interpretação constituem uma espécie de tripé da vivência histórica de todo ser pensante e agente. Esse tripé funciona tanto no âmbito do quotidiano da pessoa «comum» como no do profissional «incomum». Comum é o âmbito do senso comum, do mundo da opinião, nos quais toda pessoa vive, pensa e age. É assim um «espaço» universal no sentido de que envolve todo e qualquer ser humano, independentemente de qualquer critério de diferenciação, que se suponha "por natureza» ou historicamente forjado. «O que me interessa no homem comum é a condição humana», escreve o pensador e romancista francês André Malraux

\footnotetext{
${ }^{9}$ Pode-se ter uma ideia da composição entre vínculo com o sistema instrucional (por exemplo, currículo) e abordagens mais complexas e abrangentes ao se percorrer os sumários da revista internacional «History Education Research Journal», publicada pela History Education International Research Network (HEIRNET) desde 2000 (ISSN 1472-9474 Online).
} 
em suas Antimemórias, publicadas em $1967^{10}$. O tema é objeto de preocupação marcante da primeira metade do século 20 e já aparecera em seu famoso romance La Condition Humaine, de 1933.

Fenomenologia e existencialismo acolhem filosoficamente, entre Edmund Husserl (1859-1938) e Malraux (1901-1976), pensadores alemães, franceses, italianos e espanhóis, angustiados com a perda do sentido da vida e a desorientação histórica provocadas pelos conflitos dos anos 1870 a 1950.

Jörn Rüsen é, dentre os autores contemporâneos, o que mais cuidadosamente elaborou uma reflexão teórica sobre a natureza do conhecimento histórico e sobre sua relação com a condição humana de ser: «O homem só pode viver se interpreta a si e a seu mundo. Existe uma experiência primeva da realização humana da vida, cujo domínio cultural é efetivado por tal interpretação: a experiência temporal da contingência ${ }^{11}$.» De certa maneira, essa fórmula ecoa um grande pensador espanhol do século 20, José Ortega y Gasset, que escreveu em suas Meditaciones del Quijote: «Yo soy yo y mi circunstancia y si no la salvo a ella no me salvo yo ${ }^{12}$.»

A questão «existencial», da circunstância, do meio ambiente cultural, da marca do tempo na constituição de todo e qualquer sujeito, é decisiva para a consciência histórica. Lida-se com um «ambiente» a ser reflexivamente dominado pelo agente, de modo a ser este o responsável primeiro pelo pensar e fazer história - e não inversamente, como se fosse ele mero produto determinado do «ambiente» ${ }^{13}$.

É nesse ambiente que se institui e consolida a consciência história. Ela é a âncora reflexiva sobre a circunstância individual no tempo, com cuja reflexão se constitui a identidade do indivíduo. Não parece tratar-se de um processo linear ou por etapa única $^{14}$. A relação - que se pode entender dialética ${ }^{15}$ - entre reflexão-aprendizagem -ensino aparenta possuir uma dinâmica permanente, atuar em um moto perpétuo, cujo início ou cujo fim não podem ser determinados com absoluta precisão.

Peter Seixas também reconhece a interligação entre meio cultural, identidade pessoal e narrativa histórica, ao propor um elenco de circunstâncias determinantes do entendimento da história: significação histórica, continuidade e mudança, causa e consequência, progresso e declínio, prova, empatia histórica, perspectivas históricas e dimensão ética ${ }^{16}$. Seixas promove essas «circunstâncias» ao estatuto de "categorias

\footnotetext{
${ }^{10}$ MALRAUX, 1972: 22.

${ }^{11}$ RÜSEN, 2015: 38.

${ }^{12}$ ORTEGA Y GASSET, 2004: 757.

${ }^{13}$ MARTINS, 2017: 15-36.

${ }^{14}$ MARTINS, 2019: 126-129.

${ }^{15}$ A abordagem mais adequada da dialética como método pode ser encontrada em RÖD, 1984, especialmente na introdução.

${ }^{16}$ SEIXAS \& MORTON, 2013.
} 
organizacionais» de todo e qualquer pensamento histórico. Elas seriam igualmente reconhecíveis no teor das narrativas ${ }^{17}$.

A expressão narrativa da consciência histórica consolidada se dá tanto no âmbito do dia a dia de qualquer pessoa como na lide profissional dos especialistas em pesquisa histórica. Um e outro - em graus distintos de «sofisticação reflexiva» — articulam experiência, pensamento analítico, consciência pessoal e situacional, reconhecimento social e cultural, para, em perspectiva temporal, elaborar e enunciar um argumento narrativo que apreende, entende, explica, interpreta a si e a seu mundo. Certamente a pessoa do dia a dia, o assim chamado indivíduo do senso comum, passa por sucessivas etapas evolutivas e educativas, ao longo das quais o conteúdo e o estilo da narrativa igualmente evoluem e se tornam complexos.

A narrativa histórica, como produto da reflexão histórica pelos diferentes modos de pensamento (usualmente analítico e sintético) sobre o conteúdo vivido na experiência (empiricamente preenchida pela história em que se nasce), em seu primeiro formato é introspectiva (narro de mim para mim) e oral (narro, vale dizer: falo para mim e para outrem). O instrumento formal de expressão é a linguagem ordinária (natural), de uso corrente do narrador e de compreensão espontânea do ouvinte.

A interação entre a espontaneidade da vida pessoal em sociedade com o sistema escolar regulado, vigente nessa mesma sociedade - ao menos naquelas que, modernamente, se consideram emancipadas e críticas, como as inseridas no modelo ocidental prevalente desde o final do século 18 - impõe a aquisição de competência literária (ler e escrever) e a obrigatoriedade de exprimir-se segundo cânones. A gramática e as regras de estilo são exemplos de cânone. A historiografia científica ocidental é mais um cânone, dentre outros possíveis ${ }^{18}$. O aprendizado dos modos de pensar historicamente, na interface história-ciência e história-vivida, no meio escolar (para além do meio social e, por vezes, em conflito com este), cobra assim o estabelecimento de padrões metódicos de desempenho que vão além da espontaneidade reflexiva do "senhor qualquer um» - sem qualquer conotação pejorativa: como o Monsieur Tout-le-monde em francês, Mister Everyone em inglês, Ein Jeder em alemão, e assim por diante.

A educação histórica pressupõe (e, ao mesmo tempo, tem por meta) uma iniciação (mínima) à capacidade (competência) de refletir historicamente. Na língua inglesa tal aptidão passou a ser chamada de «historical literacy», algo como «alfabetização histórica» ${ }^{19}$ : «The goal of historical literacy includes helping students become literate about the discipline as well as the subject matter of history.» [...] «A historically literate person must be able to think historically.» Ser historicamente «alfabetizado» significa conhecer

\footnotetext{
${ }^{17}$ PECK \& SEIXAS, 2008.

${ }^{18}$ MARTINS, coord., 2010.

${ }^{19}$ DOWNEY \& LONG, 2016: 7, 17.
} 
informações, mas igualmente saber lidar com elas de modo a elaborar uma narrativa argumentada pertinente e sustentável.

\section{NARRATIVA HISTÓRICA, NARRATIVA HISTORIOGRÁFICA}

Aqui cabe uma distinção entre narrativa historiográfica e narrativa histórica. A sustentabilidade argumentativa, a pertinência empírica, a consistência interpretativa de uma narrativa aplicam-se em primeiro lugar à narrativa historiográfica, cuja aceitação depende da adoção e da aplicação de procedimentos metódicos precisos e controláveis. A narrativa histórica, elaborada pelo «senhor qualquer um», obedece a seu nível de experiência e compreensão da vida prática, acerca de cujo desenrolar e realização no tempo reflete ele e produz a respectiva narrativa. A narrativa não deixa de ser histórica (é um fato empírico da ação humana no tempo), embora não esteja dotada da acuidade metódica requerida da narrativa historiográfica.

Inúmeras pesquisas sobre o processo de aprendizagem da História produzem uma espécie de medição do alcance da compreensão dos fenômenos históricos por alunos do sistema escolar mediante a elaboração de narrativas. Os relatos sobre tais práticas didáticas incluem uma dimensão estética fundamental: orientar alunos a aprender História tanto quanto aprender a expressar sua compreensão do aprendido. Há três polos convergentes nessa ação estética para adquirir a competência narrativa fundada em conhecimento sustentável: (a) o fundamento primeiro são a historiografia disponível e a prática metódica da pesquisa científica em História; (b) o polo operador, no âmbito do sistema escolar, é o docente (sua formação, sua competência em ensino/aprendizagem, sua interação com a historiografia); (c) o discente em formação (em seus múltiplos aspectos: faixa etária, inserção socioeconômica, pertencimento cultural) Um interessante exemplo de um mix entre estética, gnosiologia e epistemologia na organização do ensino-aprendizado de História está na estratégica da "aula-oficina», inspirada na experiência inglesa, como forma de compensar, suprir, superar o estilo clássico da «aula expositiva» («aula conferência») tradicionalmente praticada ${ }^{20}$.

A elaboração e o enunciado de uma narrativa, seja histórica em sua generalidade, seja historiográfica, como um caso específico da historicidade em geral, requer compromisso com a verossimilhança. $\mathrm{O}$ valor gnosiológico (a qualidade do conhecimento adquirido) e o valor epistemológico (a demonstrabilidade da explicação em bases controláveis) dependem de uma espécie de contrato social entre o falante e o ouvinte, entre o autor e o leitor. $\mathrm{O}$ que se aprende, o que se narra, o que se ensina requer estar revestido de uma qualidade fundamental: confiabilidade e controlabilidade.

O polo fundamental é o historiográfico, fonte primária da formação em História. A formação do historiador e a do professor de História possuem um tronco comum,

${ }^{20}$ BARCA, 2004. 
que se deve entender indispensável: a habilitação a realizar pesquisa e a alcançar conhecimento empiricamente pertinente e argumentativamente demonstrável. A função estruturante da educação histórica alcança nesse particular um nível especializado, com o objetivo de formar um profissional capaz de entender, produzir e ensinar o conhecimento histórico. Esse é o contrato aplicado à prática da educação histórica em seu meio mais imediato: o dos profissionais atuantes dentro e para além do sistema escolar.

Como o contrato inclui uma cláusula de veracidade, esteio da confiabilidade cognitiva e epistêmica, importa ter consciência das exigências mínimas a ser atendidas por uma narrativa histórica/historiográfica. Os profissionais de ciência não deixam de ser indivíduos pessoal, social e culturalmente identificáveis. A ciência, em tese, não se transforma em torre de marfim em que se refugiam seus profissionais, ao isolar-se do resto do mundo, como se pesquisa e resultados de pesquisa não houvessem sido suscitados no mundo e a ele não se destinassem. A relação entre saber cientificamente fundamentado e saber fundado em opinião constitui um desafio valorativo constantemente posto a cada sociedade. $\mathrm{O}$ conflito entre razão e mito, entre ciência e palpite, entre certeza insegura e segurança incerta é permanente. A certeza é insegura, pois seu valor de verdade depende das fontes disponíveis, das condições de pesquisa e dos meios de investigação existentes ao tempo do trabalho realizado. A segurança é incerta, porque o sentimento subjetivo ou coletivo de saberes seguros frequentemente depende de crenças e convicções, mais do que de argumentos e demonstrações. As circunstâncias do tempo, do local, da sociedade, da cultura - enfim: do contexto amplo em que se busca conhecer a verdade possível — variam e evoluem. Nem toda afirmação sobre o mundo e seu sentido vale tão trivialmente quanto a sentença que afirma que o céu é, parece, aparenta ser azul.

A responsabilidade subjetiva de cada indivíduo com relação à narrativa que elabora e enuncia, seja ele um cidadão qualquer, um pesquisador, um docente ou mais lá quem for, é - como o compromisso com a veracidade - outra cláusula do contrato social da educação (histórica ou não).

Qualquer investigador deve perguntar-se sobre as consequências individuais e sociais de seu fazer particular e institucional. É igualmente necessário que o planejamento de um projeto de pesquisa inclua um valor-guia fundante: o cuidado ao lidar com outrem. Em particular quando esse outrem é um jovem ser humano in fieri, mergulhado no sistema escolar de uma dada sociedade.

Historiadores e docentes jogam, pois, jogos perigosos - como diz Margaret MacMillan $^{21}$. Nos conflitos das interpretações, no cenário dos princípios éticos e na arena dos comportamentos morais a História é usada e dela também se abusa. Se é certo que os historiadores se ocupam primariamente de acontecimentos passados, eles não são os «donos» do passado. Tampouco o passado é um dado autoevidente e de acesso

${ }^{21}$ MACMILLAN, 2010. 
imediato. Lidar com ele requer, contudo, um grau de especialização comprometido com os princípios e as regras aceitas e praticadas no meio profissional. Pesquisa histórica formal, por conseguinte, não é para amadores - por mais esclarecidos que possam ser. Pensar historicamente certamente não é monopólio dos historiadores. Afinal, todos buscam descobrir ou instituir sentido no tempo.

MacMillan exprime com clareza o que ultrapassa o quadro ético de referência da pesquisa histórica: «Nós abusamos [da História] quando inventamos mentiras ou escrevemos histórias que mostram apenas uma perspectiva ${ }^{22}$.» A responsabilidade do pesquisador em História, assim, é grande - contribuir para que o entendimento do mundo faça sentido alcança a especialidade internamente, mas atinge também todo o mundo externo a ela. Para a autora, história malfeita (mal pesquisada, mal narrada) conta só uma parte de histórias complexas; exige demasiado dos protagonistas, ao esperar que tenham pensado ou tomado decisões incompatíveis com seu tempo; ignora os matizes das ações no passado em benefício de versões convenientes ao jogo do presente e acarreta a falência da complexidade, dentre outras situações comparáveis. Os exemplos apontam com clareza como tal modo de «fazer história» infringe o princípio ético maior do compromisso com a verdade possível. A busca da verdade possível desafia os dogmatismos e as generalizações confortáveis. O rigor metódico ajuda a pensar com mais independência e clareza, mesmo no fluxo contínuo dos desafios renovados que cada tempo, cada sociedade, cada cultura tem de enfrentar.

\section{PERSPECTIVAS}

Educar, educar-se historicamente significa igualmente pensar em si e aos demais conjuntamente. A educação histórica combina rigor científico em sua origem com práticas moralmente reguladas no espaço público. Impõe-se assim ao docente um imperativo ético com responsabilidade social. Operacionalizar tal combinação é um desafio permanente. Recorrer ao imperativo categórico kantiano pode ser uma boa perspectiva de gestão de tal operacionalização. Para Kant, a máxima do agir deve ser tal que nada se deve fazer sem levar em conta o outro ${ }^{23}$. Assim o outro jamais deve ser meio para mim, e a máxima que eu adote deve poder ser adotada por outro sem que eu reclame. O otimismo pressuposto por essa abordagem é patente. Na interação social, a prevalência da dignidade pessoal do ser humano, de sua liberdade originária e de sua autonomia normativa deveria ser óbvia. Infelizmente não o é, o que confere ao processo educacional e à relação ensino-aprendizagem missão, certamente árdua, mas em nada impossível. O generoso altruísmo na concepção kantiana passou às declarações universais dos direitos humanos e dificilmente se pode deixar de notar o quanto tal forma

\footnotetext{
${ }^{22}$ MACMILLAN, 2010: XI.

${ }^{23}$ KANT, 1785.
} 
de conceber o ser humano e seu agir marcou a cultura ética e política contemporânea. Em particular a missão educacional. Como já foi dito, tal missão é permanente, duradoura como um moto perpétuo, que se reinicia a cada geração. A cada tempo, velhos e novos desafios se sucedem - a roda da fortuna não cessa de girar.

\section{BIBLIOGRAFIA}

AUBRY, Carla; GEISS, Michael; MAGYAR-HASS, Veronika; OELKERS, Jürgen, coord. (2015) — Education and the State: International perspectives on a changing relationship. Londres; Nova Iorque: Routledge.

BARCA, Isabel (2004) — Aula Oficina: do Projecto à Avaliação. In BARCA, Isabel, org. - Para uma Educação Histórica com Qualidade: Actas das IV Jornadas Internacionais de Educação Histórica. Braga: CIEd/Universidade do Minho; Instituto de Educação e Psicologia/Universidade do Minho, p. 131-144.

DOWNEY, Matthew T.; LONG, Kelly A. (2016) - Teaching for Historical Literacy. Building Knowledge in the History Classroom. Nova Iorque: Routledge.

HILL, Christopher (1972) - The world turned upside down. Radical ideas during the English Revolution. Nova Iorque: Viking Press.

KANT, Immanuel (1785) - Grundlegung zur Metaphysik der Sitten [Fundamentação da Metafísica dos Costumes]. Berlim: Academia Prussiana das Ciências; Walter de Gruyter. (Obras Completas; IV).

MACMILlAN, Margaret (2010) - Dangerous Games. The Uses and Abuses of History. Nova Iorque: Modern Library.

MALRAUX, André (1972) - Antimémoires, Paris: Gallimard. (Col. «Folio»).

MARTINS, Estevão de Rezende, coord. (2010) - A História pensada. Teoria e metodologia na história europeia no século 19. São Paulo: Contexto.

MARTINS, Estevão de Rezende (2011) - História: consciência, pensamento, cultura, ensino. «Educar em Revista», n. ${ }^{42}$, p. 43-58. Disponível em <https://doi.org/10.1590/S0104-40602011000500004>. (2017) - Teoria e filosofia da História. Contribuições para o ensino de História. Curitiba: W. A. Editores. (2019) - Consciência histórica. In FERREIRA, Marieta de M. Ferreira; OLIVEIRA, Margarida M. D. de, coord. - Dicionário do ensino de História. Rio de Janeiro: Editora da FGV.

ORTEGA Y GASSET, José (2004) - Meditaciones del Quijote. Madrid: Ed. Taurus; Fundación José Ortega y Gasset. (Obras Completas; I).

PECK, Carla; SEIXAS, Peter (2008) - Benchmarks of Historical Thinking. First Steps. «Canadian Journal of Education», vol. 31, n. ${ }^{\circ}$, p. 1015-1038.

PEREZ, Carlota (2010) - The financial crisis and the future of innovation: A view of technical change with the aid of history. "Working Papers in Technology Governance and Economic Dynamics», n. ${ }^{\circ} 28$. Norway: The Other Canon Foundation; Estonia: Tallinn University of Technology, TUT Ragnar Nurkse Department of Innovation and Governance.

RÖD, Wolfgang (1984) — Filosofia dialética moderna. Brasília: Editora da UnB (orig. Munique: Beck Verlag, 1974).

RÜSEN, Jörn (2015) - Teoria da História. Uma teoria da História com ciência. Curitiba: Editora da UFPR.

SEIXAS, Peter; MORTON, Tom (2013) - The Big Six: Historical Thinking Concepts. Toronto: Nelson Education.

TOURAINE, Alain (1993) - The crisis of progress. «European Review», vol. 1, n. ${ }^{2}$, p. 117-123.

URBAN, Ana Claudia; MARTINS, Estevão C. de Rezende; CAINELLI, Marlene, org. (2018) - Educação Histórica. Ousadia e Inovação em Educação e em História. Escritos em homenagem a Maria Auxiliadora Moreira dos Santos Schmidt. Curitiba: W. A. Editores. 



\title{
A AULA-OFICINA COMO POSSIBILIDADE DE MUDANÇA METODOLÓGICA NA FORMA DE ENSINAR HISTÓRIA NO BRASIL
}

\author{
MARLENE CAINELLI*
}

\begin{abstract}
Resumo: Este texto se propõe pensar a trajetória de Isabel Barca na área de educação histórica no Brasil e como a influência de seus escritos atingiu os professores e pesquisadores nas pesquisas e na prática do ensino de História. Iremos relatar uma experiência realizada com 9 alunos do curso de História da Universidade Estadual de Londrina, Brasil, que planejaram aulas de história na perspectiva da metodologia da aula-oficina (2004). As contribuições do pensamento de Isabel Barca se efetivaram na valorização dos conhecimentos prévios, no trabalho com fontes divergentes, na reestruturação do conceito de conteúdos substantivos com a inclusão dos conteúdos de segunda ordem possibilitando uma formação histórica menos pautada na instrumentalização de objetivos. A aula-oficina considera a natureza do conhecimento histórico e as possibilidades de uma formação humanista que compreenda o mundo para além do seu tempo e de seu espaço, entendendo os homens em suas épocas e em seus esforços de viverem suas histórias.
\end{abstract}

Palavras-chave: Isabel Barca; Educação histórica; Aula-oficina; Ensino de História.

Abstract: This text discusses Isabel Barca's path in the field of History Education in Brazil and how her texts reached the teachers and researchers on their researches and on their History teaching practice. We will describe an experience carried out with 9 students from the History course at the State University of Londrina, Brazil, who planned History classes in the perspective of the classroom-workshop methodology (2004). The contributions from Isabel Barca's thoughts became effective on the valorization of the previous knowledge, in the work with divergent sources, in the restructuration of the concept of substantive content with the inclusion of the second order contents, enabling a historical formation that is less guided by the instrumentalization of objectives. The classroom-workshop considers the nature of the historical knowledge and the possibilities of a humanist formation, which would understand the world beyond its time and space, understanding men in their times and in the effort to live their stories.

Keywords: Isabel Barca; History education; Classroom-workshop; History teaching.

\section{INTRODUÇÃO}

Pensar o trabalho de Isabel Barca na área da educação histórica nos remete para a ideia daquilo que a ação humana mobiliza permitindo que certas pessoas imprimam sua marca na cultura histórica do seu tempo. É inegável a contribuição da Historiadora para o ensino e aprendizagem da história e para o pensar do mundo na contemporaneidade, em suas palavras «uma das maiores potencialidades da História é a consciência da profundidade que ela proporciona a quem procura compreender o mundo» ${ }^{1}$. Nesse aspecto acreditamos que Isabel Barca contribuiu para que os indivíduos tenham

\footnotetext{
* Universidade Estadual de Londrina (UEL); CITCEM. E-mail: cainelli@uel.br.

${ }^{1}$ BARCA, 2011.
} 
condições a partir do desenvolvimento do pensamento histórico de compreender seu mundo.

A ideia de compreensão do mundo ao alcance dos indivíduos marca a trajetória de pesquisa de Isabel Barca que se insere em duas abordagens relacionadas ao ensino de História. De um lado, enquadra-se no campo das pesquisas e estudos acerca da Educação Histórica e a epistemologia da história e, de outro, as perspectivas relacionadas a metodologia do trabalho de ensinar e aprender História em sala de aula.

No Brasil a Educação Histórica ganha força a partir do Seminário Investigar no ensino, uma prática do professor, ministrado pela Prof. ${ }^{a}$ Dr. ${ }^{a}$ Isabel Barca, no Programa de Pós-Graduação em Educação, UFPR, em 2003. O seminário permitiu o aprofundamento da fundamentação teórica e metodológica na perspectiva da Educação Histórica, tomando como referencial as pesquisas desenvolvidas, especialmente, por investigadores portugueses, mais especificamente, as que privilegiam as questões relativas às ideias históricas de alunos na perspectiva de um ou mais conceito(s) histórico(s) em concreto. Também foi possível a partir do seminário perspectivar uma nova forma de ensinar história na escola.

O diálogo estabelecido pela pesquisadora Isabel Barca com os grupos no Brasil pode ser evidenciado pelas pesquisas desenvolvidas com a temática da educação histórica. No caso da Universidade Estadual de Londrina pode ser observado na forma de escolha das metodologias e nas referências bibliográficas que se reportam ao repertório de investigações produzidas em Portugal. Também a cultura escolar brasileira teve renovada sua forma de pensar o ensino de história a partir da relação com a epistemologia da história e com o narrar historicamente como parâmetro para formação do pensamento histórico. Nesse sentido Isabel Barca afirma que:

Em História, a aprendizagem é orientada para uma leitura contextualizada do passado a partir da evidência fornecida pelas variadíssimas fontes. A História não trata de certezas sobre um passado considerado fixo até que novos factos sejam descobertos; existem construções historiográficas diferentes, por vezes a responder a perguntas muito próximas, mas com enfoques diferentes. Numa sociedade aberta, torna-se cada vez mais óbvia esta característica da História - a de que não se aceita apenas «uma grande narrativa» acerca do passado -, já que os historiadores podem produzir narrativas divergentes, fruto de perspectivas diferenciadas sobre as mesmas fontes ou situações ${ }^{2}$.

${ }^{2}$ BARCA, 2006: 95. 
A questão da verdade histórica sempre esteve entre as preocupações da pesquisadora. As formas complexas de entendimento do conhecimento histórico mobilizam as operações mentais da consciência histórica expressas por esse narrar: a experiência histórica, a interpretação histórica e a orientação histórica, as quais podem mobilizar estratégias estéticas, cognitivas e ético-políticas da cultura histórica de uma sociedade. Estas são avaliadas por meio dos critérios de plausibilidade ligados à pertinência empírica, normativa e narrativa estruturando os critérios de verdade histórica ${ }^{3}$. Em que pese a subjetividade da verdade histórica as formas de lidar com o passado precisam estar ancoradas em sua plausibilidade. Assim, Isabel Barca argumenta:

A educação histórica é um campo de investigação que pressupõe e não autoriza a que, em História, se legitime toda e qualquer interpretação do passado: o compromisso com as fontes disponíveis e a coerência com o contexto constituem princípios em que se baseia a validação de uma «conclusão» histórica [...]. A mobilização destes princípios ajudará também a distinguir entre níveis de discurso sobre o passado especulativo, histórico ou de senso comum. Os jovens, tal como os adultos, precisam de exercitar estas competências de selecção e avaliação da informação com base em critérios racionais, sem esquecer o sentido humano da vida.

A didática da história no Paraná e principalmente na região norte do Paraná, Brasil, foi marcadamente influenciada no século XXI pelo pensamento de Isabel Barca. A forma de ensinar história perspectivada por uma pedagogia dos objetivos caracterizados nos verbos imperativos desassociados da realidade dos alunos e de suas necessidades de orientação temporal condicionava o ensino de história a uma imagem negativa perante os alunos de uma disciplina enfadonha e sem sentido ao narrar uma história fixa de um tempo passado que não se relacionava com o presente e muito menos perspectivava um futuro.

A forma do trabalho histórico com as fontes se resumia a uma classificação de documentos que não alcançava a perspectiva da evidência histórica. Teríamos que iniciar a mudança conceitual do que se pensava ser o ensino de história pela alteração da ideia do que era o trabalho com fontes já que não havia naquele momento possibilidades de análise dos documentos como fontes indiciárias de novas hipóteses sobre o passado e diferentes interpretações. Mesmo os melhores livros didáticos de história que conseguiam superar o tratamento das fontes como meras ilustrações ou apenas informação sobre o passado tratavam as fontes como vestígios para se escrever a história.

\footnotetext{
${ }^{3}$ FRONZA, 2012.

${ }^{4}$ BARCA, 2007: 6 .
} 
Havia e ainda há em alguns casos uma forma provocativa metodológica de se usar como sinônimos de fontes documentos históricos e evidência histórica.

Outra questão importante para um ensino de história que valorizasse a relação entre os sujeitos históricos diz respeito a empatia histórica. Não há possibilidade de formação do pensamento histórico sem entender o outro e as razões de suas ações. Assim como pensar em um ensino de história que excluísse os alunos do entendimento de seu lugar no mundo.

A possibilidade de um ensino de história que servisse de orientação temporal para os indivíduos possibilitando interpretações com o diálogo entre sujeitos do presente e do passado que vivem em suas épocas e podem estabelecer relações vivas em análise entre fontes diversas só seria possível com uma mudança de entendimento do uso da fonte histórica. E esta mudança se concretizou a partir do estudo da aula-oficina.

\section{MUDANDO A FORMA DE ENSINAR HISTÓRIA: METODOLOGIA DA AULA-OFICINA}

Isabel Barca é referência fundamental na mudança de paradigma na forma de ensinar história nas escolas do Paraná. O percurso de constituição de uma nova forma de ensinar baseada na educação histórica e na reflexão proporcionada pela proposta apresentada no texto Aula Oficina: do Projecto à Avaliação publicado nas Actas das Quartas Jornadas de Educação Histórica realizadas em Portugal em 2004, teve como polo irradiador a Universidade Estadual de Londrina, em cursos de graduação em História, Programas de formação continuada de Professores e Programas de Iniciação à docência onde a perspectiva metodológica escolhida foi a aula-oficina.

Em entrevista publicada na revista «Nova Escola», Isabel Barca assim explica o que é a aula-oficina:

É um modo de trabalhar que organizei em 1999, resultado das aulas que ministrava na Universidade do Minho. A ideia é que, primeiramente, o professor selecione um conteúdo, pergunte aos alunos o que eles sabem a respeito e, então, selecione as fontes históricas pertinentes para a aula. Em seguida, ele deve orientar os estudantes a analisar os materiais, fazer inferências e comparações. Todos se envolvem no processo e produzem conclusões históricas, que podem ser mais ou menos válidas e mais ou menos próximas às dos historiadores. No entanto, elas devem sempre ser valorizadas, avaliadas e reconceitualizadas com a ajuda do educador. Assim, as crianças tomam consciência do que aprenderam, do que falta saber e do que mais gostariam de conhecer. A aula-oficina vai contra a corrente que não se preocupa com o que ensinar e prioriza em manter o grupo motivado5.

\footnotetext{
${ }^{5}$ Entrevista concedida à revista «Nova Escola», 1 de março de 2013.
} 
O conjunto de diretrizes que têm orientado as investigações científicas realizadas no campo da educação histórica se articula intrinsecamente com a forma de ensinar de história. O foco da investigação delimitado pelo campo da Educação Histórica, uma área de investigação centrada nas questões relacionadas à cognição e metacognição histórica, tendo como fundamento principal a própria epistemologia da História, encontram-se estudos sobre aprendizagem histórica, consciência histórica, ideias substantivas, ideias de segunda ordem em História e sobre narrativas históricas. As categorias definidas pela educação histórica elaboram instrumentos de investigação que evidenciam as ideias históricas dos alunos e como é possível perceber a progressão destas ideias no âmbito da disciplina de história. A observação e a investigação das ideias dos alunos e dos professores proporcionam no ato do exercício do professor o diálogo, as ideias, as interferências cotidianas externas e internas na produção do conhecimento histórico.

Este modelo de investigação qualitativa expôs, para o ensino de história, o pensar dos sujeitos sobre questões como: o sentido da história, o sentido do passado, as verdades históricas, a provisoriedade do conhecimento. Estes conceitos são categorias centrais para se pensar o ensino de história. Podemos afirmar que estas questões interferem na forma como os alunos aprendem, no conteúdo do livro didático e nos saberes dos professores.

As pesquisas seguiram o curso de se aproximar do pensamento dos alunos. De perspectivar através dos conhecimentos prévios as ideias apresentadas pelos indivíduos sobre a História. Também se encaminharam para se articular aos conhecimentos históricos e produção humana no tempo e no espaço com o trabalho com as fontes em sala de aula.

Neste texto iremos nos deter sobre o programa de iniciação à docência e as articulações dialogadas com o pensamento de Isabel Barca. No ano de 2012 a partir de um programa do governo federal do Brasil de integração entre a Universidade pública e as escolas de ensino fundamental desenvolvemos atividades de formação de professores com alunos formandos do curso de História da Universidade Estadual de Londrina.

Este programa que foi nomeado de Programa Institucional de Bolsa de Iniciação à Docência (Pibid) configura-se como um programa do Ministério da Educação do Brasil financiado por sua agência de fomento Coordenação de Aperfeiçoamento de Pessoal de Nível Superior (CAPES) e tem como objetivo elevar a qualidade das ações acadêmicas voltadas à formação inicial de professores nos cursos de licenciatura das instituições de educação superior, promovendo a integração entre ensino superior e ensino básico por meio da inserção dos licenciandos no cotidiano de instituições públicas de educação básica. Os professores das escolas inserem-se no programa como supervisores, exercendo também a função de formadores, tornando-se assim elos de ligação entre universidade e escola.

No curso de História elaboramos um projeto para desenvolver as atividades de formação de professores de História a partir das ideias da pesquisadora portuguesa 
Isabel Barca. Na proposta pensada era necessário superar o ensino dos fatos históricos, sem a problematização e que não prioriza a análise de diferentes fontes. Nosso objetivo era formar um quadro de compreensão das ideias históricas dos alunos sobre que sentidos e usos os estudantes e os professores fazem do passado na sua relação com o presente e o futuro a partir do entendimento do que é evidência história e significância história tendo como metodologia o trabalho com a aula-oficina.

A importância da metodologia da aula-oficina pode ser evidenciada na forma como Seixas ${ }^{6}$ citado por Parkes e Donnelly ${ }^{7}$ define o pensamento histórico:

Como as experiências coletivas organizadoras do passado, tais que formam um modo significativo de pensar o presente. Ele sugere que há três elementos do entendimento histórico dos estudantes. O primeiro é a habilidade de dar importância à informação histórica e estabelecer critérios pelos quais se pode julgar a significância de várias narrativas do passado, frequentemente competindo entre si. O segundo elemento é a abordagem epistemológica pela qual as interpretações são revistas através da inclusão de nova evidência ou opinião. Este elemento envolve as habilidades de análise de fonte, a integração de opinião secundária e a aplicação de molduras pelas quais se pode julgar a confiabilidade da cacofonia de vozes que falam do passado e do presente. O terceiro elemento incorpora ação, empatia e julgamento moral ${ }^{8}$.

A aula-oficina possibilita ao professor e ao aluno estas experiências coletivas de formação do pensamento histórico nos três fundamentos enunciados: a importância da informação, a abordagem epistemológica e a empatia pelo passado. Nesse projeto envolveram-se 9 alunos de graduação e uma professora de História da Educação Básica. As atividades foram desenvolvidas durante o segundo semestre de 2012 no Colégio Gabriel Martins com alunos da educação básica do ensino fundamental.

O resultado do projeto foi publicado em um número especial da Revista «História \& Ensino» de 2012 ${ }^{9}$. Este dossiê contou com artigos dos alunos pibidianos que participaram do projeto e relataram suas experiências com a aula-oficina. A apresentação do dossiê indicava que:

\footnotetext{
${ }^{6}$ SEIXAS, 2006.

${ }^{7}$ PARKES \& DONNELLY, 2014.

${ }^{8}$ PARKES \& DONNELLY, 2014: 6.

${ }^{9}$ A revista «História \& Ensino» é uma publicação do Laboratório de Ensino de História do Departamento de História da Universidade Estadual de Londrina que desde 1994 publica artigos inéditos, traduções, resenhas e entrevistas relacionados ao Ensino de História. Disponível em <http://www.uel.br/revistas/uel/index.php/histensino>.
} 
Elaborar um número especial da revista com estes artigos condiz com a linha editorial de História \& Ensino, concomitante aos objetivos do Laboratório de Ensino de História da UEL, na medida em que pensamos o «fazer» do pesquisador diretamente ligado ao "fazer» do professor. Estes artigos não são meros relatos de experiência pedagógica, mas sim, artigos acadêmicos, escritos por futuros professores inseridos em um movimento de "engajamento" para se tornarem profissionais reflexivos. Em outras palavras, os artigos nos mostram a articulação pesquisa e ensino, no caso, tomando o campo da chamada Educação Histórica como fundamentação empírica e teórica ${ }^{10}$.

Os alunos se dividiram na tarefa de escolher as fontes e temas para o trabalho em sala de aula. Foram selecionados diversos tipos de fontes: novelas de televisão, cinema, literatura, jornais, peça de teatro, música. Os conteúdos substantivos se dividiram entre a escravidão no Brasil, a Ditadura Militar brasileira, a Sociedade Egípcia e a História Local.

Para este texto por conta das dimensões exigidas selecionamos apenas dois trabalhos dos nove desenvolvidos no projeto e apresentados na revista «História \& Ensino» ${ }^{11}$. São as aulas-oficinas de Henrique Bresciani e Jemina Fernandes juntamente com Marcela Cordeiro.

Henrique Bresciani assim definiu sua proposta de trabalho:

Foram realizadas aulas-oficina (BARCA, 2004) considerando uma perspectiva de ensino de História que tem como propósito o desenvolvimento do pensamento histórico em detrimento de modelos que se pautam na transmissão de conteúdo. As aulas foram estruturadas tendo em vista a necessidade de trazer documentos históricos para o contexto de sala de aula. Estabeleceu-se um diálogo com elementos que envolvem o aluno no presente, partindo do pressuposto de que o ensino de história se efetiva ao possuir uma utilidade prática para a vida (RÜSEN, 2001) ${ }^{12}$.

\footnotetext{
${ }^{10}$ RAMOS, 2012: 5.

${ }^{11}$ Apresento aqui os títulos e os autores dos trabalhos que não serão desenvolvidos no texto: ANUNCIAÇÃO, Ana Paula; SPERANDIO, Amábile (2012) - Aula-oficina: uma proposta de utilização de documentos históricos em sala de aula. "História \& Ensino», vol. 18, número especial, p. 131-156. FORTUNATO, Aline; ARANHA, Cinthia (2012) - Para além do lazer: a utilização do filme como recurso didático em sala de aula. "História \& Ensino», vol. 18, número especial, p. 95-109. PAVIANI, Bruno; FERREIRA Thaisa Lopes (2012) - A música e a Ditadura Militar: como trabalhar com letras de música enquanto documento histórico. "História \& Ensino», vol. 18, número especial, p. 111-130.

${ }^{12}$ BRESCIANI, 2012: 31.
} 
Em sua proposta o aluno Henrique Bresciani buscou através do trabalho com a novela Escrava Isaura ${ }^{13}$ discutir a questão da diversidade possível de fontes ao entender a novela como irradiadora de conteúdo histórico. A primeira pergunta feita pelo professor que se apresenta como investigador social foi se os alunos entendiam que filmes e novelas poderiam ser utilizados para estudar história. Por quê? «A grande maioria, com exceção de dois alunos, concordou plenamente em que ambos são úteis ao saber histórico. As justificativas para a resposta afirmativa, na maioria dos casos, tenderam para a assimilação do conteúdo histórico expresso na novela como a própria verdade sobre o passado.» Desta forma acreditavam que as novelas poderiam retratar o passado tal qual aconteceu. Os alunos que rejeitaram a ideia do uso das fontes escolhidas argumentaram que não se pode usar uma «história inventada para estudar a história». Além da discussão sobre a validade das fontes escolhidas, também foi realizada uma discussão sobre ficção e história, anacronismo. No desenvolvimento da aula-oficina foram utilizadas várias fontes para o trabalho didático.

A atividade foi composta de três fontes históricas, que forneciam indícios para o estudo da escravidão doméstica em um tempo coerente com o enredo da novela, e previamente os alunos haviam assistido a três cenas da novela que enfocavam a personagem de Isaura em suas atividades dentro da casa de seus senhores. A proposta da atividade partiu da análise das fontes, os alunos indicassem o que eles achavam ser fictício nos trechos da novela. Dessa forma, a atividade objetivou investigar o conhecimento dos alunos acerca do conceito de fonte histórica, sua capacidade em produzir uma interpretação e relacioná-la com outras fontes, na qual se incluí a própria novela, ao passo que também serviu para desenvolver essas competências: objetivo específico dessa aula-oficina ${ }^{14}$.

O trabalho com as fontes possibilitou ao professor perceber como os alunos realizam a confrontação das mensagens que estas apresentam. E que muitas vezes os alunos fazem afirmações sem necessariamente estabelecer conexões entre as fontes que estão estudando e que há alunos que estabelecem relações e demonstram um pensamento complexo sobre as fontes. O mais importante para Bresciani é a resposta dos alunos sobre o que acharam ter aula de história no modelo da aula-oficina:

\footnotetext{
${ }^{13}$ Em 1875, Bernardo Guimarães escreveu um romance sobre uma escrava branca, que foi publicado no mesmo ano pela editora Casa Garnier sob o título de A Escrava Isaura. Guimarães teve reconhecimento pela obra, que foi um sucesso logo após ser publicada, em parte pelo apelo feminino em razão do sentimentalismo do enredo. O livro toca em pontos abolicionistas, que eram controversos na época, e é considerado um marco na literatura abolicionista brasileira. Em 1976, a telenovela Escrava Isaura foi produzida pela Rede Globo, sendo depois várias vezes repetida em diversos horários pela emissora.

${ }^{14}$ BRESCIANI, 2012: 47.
} 
O que chamou mais atenção durante a oficina foi o aprendizado mobilizado em torno dos conceitos de segunda ordem, e outras questões que se relacionam à «natureza» do conhecimento histórico: «Eu aprendi mais sobre a história, ficção, anacronismo, verdade sobre o passado, mentira.»; "Eu gostei porque ele trouxe um outro jeito da gente estudar anacronismos e ficções»; "Gostei de tudo, porque eu não sabia de muitas coisas por exemplo: anacronismo, e que a novela Escrava Isaura tinha mais ficção do que história». A forma da oficina, a maneira de abordagem realizada, o estabelecimento de um diálogo durante as aulas, também foi outro aspecto bastante evidenciado como algo incomum, considerado como fator positivo pelos alunos: "Achei muito legal o jeito que ele dá aula, é uma maneira interessante da gente aprender história, eu gostei muito» ${ }^{15}$.

Bresciani ainda argumenta que é interessante notar que a proposta de aula-oficina, elaborada por Isabel Barca, atingiu resultados significativos, tendo em vista as transformações ocorridas no nível do pensamento histórico dos alunos. Segundo o autor, também é plausível argumentar que algumas hipóteses norteadoras da aula-oficina se sustentaram. Para tanto termina seu texto com uma citação de Isabel Barca que reforça suas ideias sobre a pertinência da utilização da aula-oficina e o sucesso da sua experiência.

Levantar e trabalhar de forma diferenciada as ideias iniciais que os alunos manifestam tacitamente, tendo em atenção que estas ideias prévias podem ser mais vagas ou mais precisas, mais alternativas à ciência ou mais consentâneas com esta. Propor questões orientadoras problematizadoras, que constituam um desafio cognitivo adequado aos alunos em presença, e não apenas um simples percorrer de conteúdos sem significado para os jovens. Desenhar tarefas adequadas ao desenvolvimento das competências em foco, que ultrapassem uma interpretação linear das fontes ou a compreensão simplista de qualquer versão histórica sobre o passado. Integrar as tarefas em situações diversificadas, não esquecendo a potencialidade de os alunos trabalharem em pares, ou individualmente, oralmente e por escrito. Avaliar qualitativamente, em termos de progressão de aprendizagem, o nível conceptual dos alunos, em vários momentos da(s) aula(s) ${ }^{16}$.

As alunas Jemima Fernandes e Marcela Cordeiro assim apresentaram seu trabalho:

A construção da nossa proposta a partir da aula-oficina (2004) teve como objetivo que o aluno pudesse identificar a possibilidade de se estudar a ditadura

\footnotetext{
${ }^{15}$ BRESCIANI, 2012: 51.

${ }^{16}$ BARCA, 2004: 136-137.
} 
militar no Brasil por meio de uma manifestação artística «as manifestações culturais de uma dada sociedade - poesias, memórias, músicas e símbolos - revelam uma totalidade complexa e contraditória de impressões e sentimentos, pois são construídas na diversidade do real e do vivido». Portanto, que ao final da aula o aluno pudesse a partir da evidência inferir ou deduzir algo sobre determinado contexto ${ }^{17}$.

$\mathrm{Na}$ proposta as autoras elencaram como objetivo desenvolver a compreensão da linguagem histórica a partir de documento no ensino de História. Nossa proposta foi discutir «o livre pensar, a censura, as metáforas e a questão da evidência histórica», no que diz respeito ao período de 1964-1984 que se refere à Ditadura Militar no Brasil através das músicas de Raul Seixas utilizando-as como documentos históricos.

A perspectiva elaborada pelas alunas para o desenvolvimento da aula-oficina se caracterizou pelo trabalho com a evidência histórica e com a ideia de que os conteúdos de segunda ordem são importantes para mobilizar a construção do pensamento histórico dando sentido a história e a si mesmos. As autoras começam a aula-oficina analisando o questionário de conhecimentos prévios a partir da categorização proposta por Ana Catarina Simão ${ }^{18}$ sobre evidência histórica. O interesse das professoras era perceber os níveis de progressão das ideias dos alunos. É importante mencionar a mobilização estabelecida pelas professoras para o desenvolvimento da aula-oficina porque desloca o planejamento do simples pensar em objetivos de ensino ou mesmo tipos de avaliação de conteúdo. É considerado o aluno como um sujeito de aprendizagem que pensa e tem ideias mesmo antes de se trabalhar os conteúdos substantivos.

A partir de duas fontes divergentes sobre o período materializadas nas letras de músicas ${ }^{19}$ da época da ditadura militar brasileira que ocorreu de 1964 a 1985, as professoras analisaram as respostas dos alunos e o resultado da aula-oficina com base nos níveis de progressão propostos por Simão ${ }^{20}$. É interessante notar que a avaliação do trabalho em sala de aula recaiu não sobre o fato de os alunos saberem ou não o conteúdo substantivo e sim sobre como estes analisaram as fontes e se relacionaram com o conteúdo exposto pelas músicas. Esta possibilidade de o professor se afastar da tradição escolar de pensar apenas o conteúdo substantivo e a aprendizagem deste como referência para o sucesso da aprendizagem só foi possível a partir do uso da metodologia da aula-oficina.

\footnotetext{
${ }^{17}$ FERNANDES \& CORDEIRO, 2012: 74.

${ }^{18}$ SIMÃO, 2011.

${ }^{19}$ As músicas «Metrô Linha 743» e «Eu te amo meu Brasil».

${ }^{20}$ SIMÃO, 2011.
} 


\section{ALGUMAS CONSIDERAÇÕES}

Passado, presente e futuro, não necessariamente nesta ordem, organizam nossos sentidos de orientação influenciando nossas ações. Descrever uma trajetória de vida profissional e acadêmica é sempre muito difícil e reducionista por parte daquele que a partir do que leu, vivenciou e ouviu seleciona atitudes e produções daquele de onde pretende definir uma trajetória, uma linha de racionalidade.

Nossa escolha recaiu sobre uma pequena parte da trajetória de Isabel Barca que se aproximou das vidas e sentidos de professores pesquisadores e alunos no Brasil. A mudança de paradigma metodológico no ensino de história que possibilita hoje aos professores planejarem suas aulas sem o dogma do conteúdo substantivo como parâmetro da aprendizagem histórica tem suas raízes nas pesquisas em educação histórica e na metodologia da aula-oficina.

É o reconhecimento da importância que a discussão sobre a aula-oficina teve para a forma de planejamento e execução das aulas de história que guiou nosso recorte e nossa recolha de dados. Dos embates entre uma tradição de aula de história marcada pela aula expositiva do conteúdo substantivo e das novas perspectivas de mudança que indicava a necessidade de se pensar o indivíduo que aprende também um ser pensante com ideias prévias e hipóteses a levantar surgiu uma metodologia que valoriza a fonte histórica, que entende o aluno como ser com autonomia de agir e direção guiada pelas suas carências de orientação.

Como afirma Isabel Barca, para se ensinar história é preciso educar historicamente preocupados com o desenvolvimento humano. É necessário intervir conscientemente a partir do que se conhece, explorar o mundo conceitual dos alunos analisando as ideias formativas. É tarefa do professor criar problemas significativos e desafiantes para quem aprende coerente com a natureza do saber histórico e com a formação de pessoas autônomas que entendam o funcionamento do mundo de forma humana e social.

\section{BIBLIOGRAFIA}

ANUNCIAÇÃO, Ana Paula; SPERANDIO, Amábile (2012) - Aula-oficina: uma proposta de utilização de documentos históricos em sala de aula. «História \& Ensino», vol. 18, número especial, p. 131-156.

BARCA, Isabel (2004) - Aula Oficina: do Projecto à Avaliação. In BARCA, Isabel, org. - Para uma Educação Histórica com Qualidade: Actas das IV Jornadas Internacionais de Educação Histórica. Braga: CIEd/Universidade do Minho; Instituto de Educação e Psicologia/Universidade do Minho, p. 131-144.

(2006) - A construção de narrativas históricas: perspectivas de consciência histórica dos jovens portugueses. In Anais do VII Encontro Nacional dos Pesquisadores do Ensino de História: Novos Problemas e Novas Abordagens. Belo Horizonte: Faculdade de Educação, Universidade Federal de Minas Gerais. (2007) - A educação histórica numa sociedade aberta. «Currículo sem Fronteiras», vol. 7, n.o 1 (jan./jun.) p. 5-9.

(2011) - Educação histórica: vontades de mudança. «Educar em Revista», n. 42, p. 59-71. 
BRESCIANI, Henrique (2012) - Novela em sala de aula: a utilização de «Escrava Isaura» em uma proposta de aula-oficina. «História \& Ensino», vol. 18, número especial, p. 31-53.

FERNANDES, Jemima; CORDEIRO, Marcela (2012) - Aula oficina: a música como proposta de produção de conhecimento histórico com os alunos. «História \& Ensino», vol. 18, número especial, p. 73-94.

FORTUNATO, Aline; ARANHA, Cinthia (2012) - Para além do lazer: a utilização do filme como recurso didático em sala de aula. «História \& Ensino», vol. 18, número especial, p. 95-109.

FRONZA, Marcelo (2012) - Intersubjetividade e a verdade na aprendizagem histórica de jovens estudantes a partir das histórias em quadrinhos. Curitiba: UFPR. Tese de doutorado. Programa de Pós-Graduação em Educação.

PARKES, Robert J.; DONNELLY, Debra (2014) - Concepções em mudança do pensamento histórico no ensino da história: um estudo de caso australiano. «Tempo e Argumento», vol. 6, n. ${ }^{\circ} 11$ (jan./abr.), p. 137-161. Título original: Changing conceptions of historical thinking in History education: an Australian case study. Traduzido por Fabrício Coelho.

PAVIANI, Bruno; FERREIRA Thaisa Lopes (2012) - A música e a Ditadura Militar: como trabalhar com letras de música enquanto documento histórico. «História \& Ensino», vol. 18, número especial, p. 111-130.

RAMOS, Marcia Elisa Tete (2012) - Editorial Dossiê. «História \& Ensino», vol. 18, número especial, p. 7-30.

RÜSEN, Jörn (2001) - A razão histórica: Teoria da história: os fundamentos da ciência histórica. Brasília: UnB.

SEIXAS, Peter (2006) - Benchmarks of Historical Thinking: a framework for assessment in Canada. Vancouver, CA: Centre for the study of historical consciousness, University of British Columbia.

SIMÃO, Ana Catarina Gomes (2011) - A importância da Evidência Histórica na construção do Conhecimento Histórico. In CAINELLI, Marlene; SCHMIDT, Maria Auxiliadora - Educação Histórica: Teoria e Pesquisa. Ijuí: Editora Inijuí. 


\title{
NARRATIVA HISTÓRICA: UMA MANEIRA DE ENSINAR E APRENDER HISTÓRIA SOB A PERSPECTIVA DA EDUCAÇÃO HISTÓRICA
}

\author{
ROSI TEREZINHA FERRARINI GEVAERD*
}

\begin{abstract}
Resumo: A pesquisa desenvolvida durante o doutoramento foi pautada em investigações na área da Educação Histórica, mais especificamente na linha da cognição histórica situada. Tomando como referência os estudos de Peter Lee ${ }^{1}$, procurei relacionar os conceitos substantivos da história do Paraná com um conceito de segunda ordem, mais especificamente, o conceito de narrativa histórica. Assumindo a ideia de que a narrativa é uma maneira de ensinar e aprender História, busquei identificar as narrativas do manual didático, as narrativas da professora e as produções dos alunos no processo de escolarização e pude constatar que existe uma convergência entre essas narrativas a qual indicou uma forte presença de determinada perspectiva da história tradicional do Paraná. Algumas considerações foram apontadas, entre elas a de que o aprendizado histórico desses alunos estaria mais próximo das formas tradicionais de pensamento histórico, e com isso a professora estaria, em parte, possibilitando a constituição de uma consciência histórica do tipo tradicional, na perspectiva de Rüsen².
\end{abstract}

Palavras-chave: Ensino de História; Educação histórica; Narrativa histórica; História do Paraná.

Abstract: The research developed during the PhD was guided by investigations in the area of History Education, more specifically in the line of situated historical cognition. Taking as a reference the studies of Peter Lee3, I tried to relate the substantive concepts of the history of Paraná with a second order concept, more specifically, the concept of historical narrative. Assuming that the narrative is a way of teaching and learning History, I sought to identify the narratives of the didactic manual, the teacher's narratives and the students' productions in the schooling process and through that I could realize that there is a convergence between these narratives, which indicated a strong presence of a certain perspective of the traditional history of Paraná. Some considerations were pointed out, and among them one that says the historical learning of these students would be closer to the traditional forms of historical thought, and with that the teacher would be, in part, making possible the constitution of a historical consciousness of the traditional type, in the Rüsen's perspective ${ }^{4}$.

Keywords: History teaching; History education; Historical narrative; Paraná's history.

\footnotetext{
* Faculdade São Braz, Curitiba; UNINA; LAPEDUH/UFPR. E-mail: rosigevaerd19@gmail.com.

${ }^{1}$ LEE, 2001; LEE, 2005.

${ }^{2}$ RÜSEN, 1992; RÜSEN, 1993.

${ }^{3}$ LEE, 2001; LEE, 2005.

${ }^{4}$ RÜSEN, 1992; RÜSEN, 1993.
} 


\section{INTRODUÇÃO}

A contribuição dos fundamentos teóricos e metodológicos na perspectiva da Educação Histórica assumidos na minha tese de doutorado ${ }^{5}$ deve-se, principalmente, à minha participação no Seminário Investigar no ensino, uma prática do professor, ministrado pela Prof. ${ }^{a}$ Dr. ${ }^{a}$ Isabel Barca, no Programa de Pós-Graduação em Educação, organizado pela Universidade Federal do Paraná (UFPR), em 2003, quando tive acesso aos estudos e investigações nessa área de pesquisa e ensino.

A partir daquele momento tenho procurado participar de discussões nesse âmbito, especialmente como pesquisadora do Laboratório de Pesquisa em Educação Histórica - LAPEDUH, assim como em Seminários, Congressos, Jornadas, enfim, eventos que têm sido organizados por diferentes instituições, de cunho local, nacional e internacional. Destaco a minha participação no grupo português durante o Estágio Científico Avançado, na Universidade do Minho, Braga, Portugal, no período de 11 de fevereiro a 30 de junho de 2008, sob a orientação da Prof. ${ }^{a}$ Dr. ${ }^{a}$ Isabel Barca, visando a um maior alargamento conceitual nessa área de investigação, pois, como acentua Barca:

O ensino de História constitui-se hoje como um fértil campo de investigação, sendo objeto de pesquisa sob diversos ângulos que integram quer perspectivas diacrônicas quer a análise de problemáticas atuais do ensino específico.

É dentro desta segunda perspectiva que a investigação sobre cognição e ensino de História [...] tem-se desenvolvido com pujança em vários países [...]. Nestes estudos, os pesquisadores têm centrado a sua atenção nos princípios, fontes, tipologias e estratégias de aprendizagem em História, sob o pressuposto de que a intervenção do professor na qualidade das aprendizagens exige um conhecimento sistemático das ideias históricas dos alunos, por parte de quem ensina (e exige também um conhecimento das ideias históricas destes últimos) ${ }^{6}$.

Tendo como referência esses pressupostos, delineei minha pesquisa de doutorado, mais precisamente na linha de investigação da cognição histórica situada, a qual engloba estudos que têm como perspectiva a compreensão das ideias de professores e alunos em contexto de ensino - aulas de história, tomando como referência o próprio conhecimento histórico. Pois, segundo Barca \& Gago, as investigações no domínio da cognição histórica têm procurado:

\footnotetext{
${ }^{5}$ Tese sob o título A Narrativa Histórica como uma maneira de ensinar e aprender história: o caso da história do

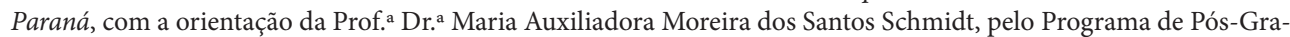
duação em Educação, Setor de Educação, Universidade Federal do Paraná, Curitiba, 2009.

${ }^{6}$ BARCA, 2005: 15.
} 
- compreender os processos cognitivos dos sujeitos ao pensarem História;

- examinar as relações entre as ideias tácitas (ideias que os alunos constroem a partir de suas vivências) e os conceitos históricos;

- explorar a compreensão dos alunos quanto aos conceitos históricos quer de natureza substantiva quer de natureza epistemológica (por exemplo, interpretação de fontes) $)^{7}$.

\section{EDUCAÇÃO HISTÓRICA: CONTRIBUTOS TEÓRICOS E METODOLÓGICOS ASSUMIDOS NA INVESTIGAÇÃO}

Tomando como referência os fundamentos teóricos e metodológicos no âmbito da Educação Histórica, procurei identificar os conceitos substantivos da história do Paraná presentes em aulas de história, assim como os conceitos de natureza epistemológica da história. Conceitos substantivos da história foram tomados na perspectiva de Peter Lee ${ }^{8}$, quando o autor aponta que são conceitos que se referem a conteúdos da história, como por exemplo o conceito de indústria, comércio, nação, protestante, escravo, tratado ou presidente, e são encontrados quando trabalhamos com tipos particulares de conteúdos históricos. Eles são parte do que podemos chamar de substância da história e, por isso, têm sido denominados conceitos substantivos. Tais conceitos pertencem a diferentes tipos de atividade humana, como a econômica, a política, a social e a cultural. No caso da História do Paraná, são conceitos como Tropeirismo, Revolução Federalista, Guerra do Contestado, entre outros.

Para o mesmo autor, conceitos de natureza epistemológica da história são aqueles que ajudam a compreender a natureza da história como ciência, envolvendo conceitos como evidência, causa, mudança, explicação, consciência histórica e narrativa, entre outros. Para o autor, não há, ainda, um termo que seja mais conveniente para designar esse conhecimento da disciplina. Muitas vezes, ele é chamado «meta-histórico», ou seja, "para além da história», porque, embora esse conhecimento não faça parte do que os historiadores estudam, é um conhecimento do tipo de estudo no qual eles estão envolvidos. Outro termo usado é conhecimento de «segunda ordem», pois se refere a uma camada do conhecimento que está além da produção do conteúdo ou da substância da história. Finalmente, um outro termo empregado é conhecimento «disciplinar», porque o conhecimento envolvido está implícito na disciplina de história, em vez de ser o que os historiadores descobrem. O autor acentua que tem usado os três termos quando se refere às ideias sobre «fazer história»".

\footnotetext{
${ }^{7}$ BARCA \& GAGO, 2001: 242.

${ }^{8}$ LEE, 2001: 13-27; LEE, 2005: 61.

${ }^{9}$ LEE, 2001: 13-27; LEE, 2005: 32.
} 
Em minha investigação, procurei relacionar os conceitos substantivos da história do Paraná com conceitos de segunda ordem, mais especificamente o conceito de narrativa histórica.

O conceito de narrativa foi tomado tendo presente que, apesar de o paradigma narrativista ter sido objeto de discussão entre filósofos e historiadores, especialmente a partir da segunda metade do século XX, o pensamento histórico possui uma lógica narrativa, pois, como diz Rüsen, no debate teórico recente não se conhece nenhum caso de contestação do caráter narrativo do pensamento histórico, e mesmo que existam trabalhos historiográficos cujo ponto principal não esteja no aspecto narrativo, isto não significa que neguem o caráter fundamental e constitutivo do narrar ${ }^{10}$.

Nessa investigação, a ideia de narrativa histórica escolar foi assumida a partir dos estudos de Husbands ${ }^{11}$, pois, para esse autor, a narrativa é uma das formas pelas quais alunos e professores dão sentido ao passado histórico, quando pensam sobre as versões do passado. Para ele, por meio das narrativas torna-se possível, em aulas de história, tratar de ideias mais abstratas sobre as suposições e crenças das sociedades do passado, sobre as formas como trabalharam ou fracassaram, e como as pessoas representavam suas relações com os outros.

Ademais, esta pesquisa toma como pressupostos os estudos de Rüsen ${ }^{12}$, que sugerem questões de como se aprende história, pois, para ele, a aprendizagem que constitui a consciência histórica vem em destaque nas narrativas, ou seja, no ato de contar histórias, porque esta é uma forma coerente de comunicação e porque trata da identidade histórica tanto do comunicador como do receptor. Isso ocorre porque as narrativas são produtos da mente humana e, com o auxílio dessas, as pessoas envolvem lugar e tempo de uma forma aceitável por elas próprias $^{13}$.

Diante disso, partindo do pressuposto de que a história como ciência possui uma natureza narrativista, minha tese foi a de que existem narrativas históricas no processo de escolarização, difundidas pelo manual didático, pelas propostas curriculares e pelas aulas da professora, e que a partir da convergência dessas narrativas ocorre a aprendizagem histórica que se evidencia nas narrativas produzidas pelos alunos. Considerando isso, levantei as seguintes questões:

- Que tipo de narrativas sobre a história do Paraná é difundido pelo manual didático, pelas propostas curriculares e pelas aulas da professora?

- Tendo em vista as narrativas difundidas na escola, como o aluno manifesta a sua aprendizagem histórica, sob a forma de narrativas?

\footnotetext{
${ }^{10}$ RÜSEN, 2001: 149-150.

${ }^{11}$ HUSBANDS, 2003.

12 RÜSEN, 1992; RÜSEN, 1993; RÜSEN, 2001.

${ }^{13}$ RÜSEN, 1993: 85.
} 
Nesse artigo destaco as narrativas produzidas pelos alunos em processo de escolarização, bem como a análise e os procedimentos adotados na categorização.

\section{NARRATIVAS PRODUZIDAS PELOS ALUNOS: ANÁLISE E CATEGORIZAÇÃO}

Essa investigação constituiu-se em uma pesquisa de natureza qualitativa e foi empreendida a partir de Observações de aulas de história, durante um ano letivo (2007), em uma turma de Ciclo II $-2 .^{\text {a }}$ etapa $-5 .^{\circ}$ ano do ensino fundamental de uma escola da Rede Municipal de Ensino de Curitiba (RME).

Assumindo a ideia de que a narrativa é uma maneira de ensinar e aprender história, busquei identificar nas narrativas do manual didático, nas narrativas da professora e nas produções dos alunos: os marcadores históricos, os marcadores de relações causais/mudanças/continuidades, marcadores temporais, marcadores espaciais e os personagens/ /agentes pessoais/sociais que constituem as narrativas, e, a partir da identificação desses marcadores, identifiquei os níveis das narrativas produzidas pelos alunos.

A professora, ao longo do ano, trabalhou os conceitos substantivos indicados no currículo da RME, bem como utilizou, mais especificamente, dois manuais didáticos que tratavam de conteúdos da história do Paraná. Em duas aulas a professora solicitou aos alunos uma produção própria, ou seja, a produção de uma narrativa. Isso ocorreu após o trabalho com os conceitos substantivos: Espanhóis, nossos primeiros colonizadores e Os bandeirantes atacam as reduções, quando solicitou aos alunos: «Escreva como você acha que viviam os índios nas missões junto aos padres jesuítas»; após o trabalho com o conceito substantivo: Revolução Federalista, quando solicitou aos alunos: «Escrevam o que entenderam sobre Revolução Federalista.»

Para esse artigo destaco as narrativas produzidas pelos alunos em relação ao conceito Revolução Federalista. Os critérios de análise das narrativas tomaram como referência os estudos de Barca ${ }^{14}$, Husbands ${ }^{15}$, Carretero \& Jacott ${ }^{16}$ e Topolski ${ }^{17}$. A partir dos elementos sugeridos por esse conjunto de autores, foi feita a categorização das ideias contidas nas narrativas dos alunos. Essa categorização consistiu em um estudo empírico baseado na metodologia da investigação qualitativa na perspectiva da Grounded Theor $y^{18}$, na qual as abstrações são construídas à medida que os dados particulares que foram recolhidos vão sendo agrupados.

A análise da trama das narrativas consistiu em identificar, inicialmente, na narrativa do manual didático, na narrativa da professora e nas produções dos alunos: os

\footnotetext{
${ }^{14}$ BARCA, 2006.

${ }^{15}$ HUSBANDS, 2003.

${ }^{16}$ CARRETERO \& JACOTT, 1997.

${ }^{17}$ TOPOLSKI, 2004.

${ }^{18}$ BOGDAN \& BIKLEN, 1994.
} 
marcadores históricos, as relações causais/mudanças/continuidades, marcadores temporais, marcadores espaciais e os personagens/agentes pessoais/sociais que constituem as narrativas.

Em seguida, à luz dos marcadores que surgiram da análise das narrativas, fiz o cruzamento dos dados e observei se os alunos mantiveram ou omitiram os marcadores das narrativas de referência, ou, ainda, se surgiram outros marcadores indicados pelos alunos. Na narrativa produzida pelos alunos, analisei, além destes construtos, o nível da trama narrativa, levando em consideração: se a produção dos alunos apresentava uma trama narrativa, um enredo, bem como a validade do conteúdo histórico.

Para a análise das narrativas dos alunos, foram considerados os marcadores das narrativas do manual didático e das narrativas da professora, ou seja, as explicações em relação à narrativa Revolução Federalista. Dos 30 alunos matriculados, 26 estavam presentes; 25 produziram as narrativas; e um (1) aluno não realizou a atividade, entregando a folha em branco.

As tramas das narrativas do manual didático e a narrativa da professora tenderam a destacar as rupturas políticas como marcadores históricos. Elas apresentam uma contextualização e cronologia do período em que ocorreu a Revolução Federalista e anunciam os eventos que se sucederam desde a Proclamação da República, bem como a instabilidade política no início do período republicano. Entre eles, ressaltam o descontentamento com a forma de governar de Marechal Deodoro da Fonseca e do vice-presidente Marechal Floriano Peixoto, apontando essa situação como a causa do início da Revolução; e os grupos que se formaram a favor e contra o governo - legalistas e federalistas, inclusive nomeando os líderes do movimento. Além disso, focalizam os acontecimentos no Paraná - O Cerco da Lapa e a invasão da cidade de Curitiba pelos federalistas, a vitória dos legalistas e o período de repressão dos legalistas em relação aos federalistas.

Quanto aos marcadores históricos, as narrativas dos alunos tenderam a manter e destacar com maior ênfase os acontecimentos referentes à contextualização política do Brasil no período em que ocorreu a Revolução Federalista. Alguns alunos (17) fizeram referência à renúncia do presidente Marechal Deodoro da Fonseca em favor do vice-presidente Marechal Floriano Peixoto. Fragmento de narrativa:

O grande descontentamento do povo por causa de Deodoro da Fonseca, que governou durante dois anos, ele, porém, havia governado como um imperador. Triste com o grande descontentamento do povo e temendo que acontecesse alguma coisa má, ele rejeitou ou abandonou a Presidência, dando o cargo da Presidência a Floriano Peixoto, o «vice» no comando. (Yvan ${ }^{19}, 10$ anos)

\footnotetext{
${ }^{19}$ Os nomes dos alunos são fictícios para preservar suas identidades.
} 
Quanto às relações causais/mudanças/continuidades, as narrativas dos alunos tenderam a manter e destacar com maior ênfase os acontecimentos em relação à renúncia/abandono do presidente Marechal Deodoro da Fonseca (17 alunos); ao fato de que este deixou o governo em favor do vice-presidente Marechal Floriano (15 alunos); ao modo de governar do presidente, semelhante ao do imperador (12 alunos); à instabilidade política no início do período republicano ( 9 alunos). Exemplo de narrativa:

A causa da Revolução Federalista foi após a Proclamação da República, por causa do Marechal Deodoro da Fonseca. As pessoas não estavam contentes com o jeito que ele governava o País. Por isso, depois de dois anos ele renunciou o cargo e quem assumiu foi o seu vice-presidente, Marechal Floriano Peixoto.

E o povo também não estava contente como ele governava, por isso a Revolução Federalista começou e foram formados os federalistas e os castilhistas. (Luiza, 10 anos)

Quanto aos marcadores temporais, as narrativas dos alunos mantiveram, com grande ênfase, o ano do início da Revolução Federalista - 1893 (10 alunos). Com menor ênfase, as narrativas mantiveram os acontecimentos relacionados com o período em que a cidade da Lapa foi defendida sob o comando de Ernesto Carneiro - 26 dias (4 alunos); com a invasão da cidade da Lapa pelos federalistas, no dia 11 de fevereiro de 1894 (2 alunos); e com a invasão da cidade de Curitiba a 20 de janeiro de 1894 (2 alunos). Exemplo de narrativa:

Em 1893 explodiu a Revolução Federalista em Rio Grande do Sul. Os federalistas, governados por Silveira Martins, tinham o objetivo de combater o governo de Floriano Peixoto.

[...]

A cidade da Lapa, já sem forças para resistir, foi invadida no dia 11 de fevereiro de 1894.

Quando Custódio de Melo invadiu Curitiba, já abandonada, a 20 de janeiro de 1894. (Dione, 10 anos)

Os alunos mantiveram os marcadores/marcos espaciais referenciados no manual didático e na narrativa da professora, sendo que muitos alunos (14) localizaram espacialmente o início da Revolução Federalista, no Rio Grande do Sul; alguns (11) fizeram referência ao Cerco da cidade da Lapa no Paraná; alguns (6) fizeram referência à invasão da cidade de Curitiba pelos federalistas; somente um (1) aluno citou a transferência da capital do Paraná para a cidade de Castro. Fragmento da narrativa que apresentou o maior número de marcadores espaciais: 
Quando Floriano começou a governar explodiu a Revolução Federalista no Rio Grande do Sul. [...] Para combater os federalistas os castilhistas concentraram-se na cidade da Lapa. [...] os federalistas também invadiram Curitiba. (Cristina, 10 anos)

Os alunos mantiveram alguns personagens sociais usados, tanto na narrativa do manual como nas narrativas da professora. Os personagens citados com maior ênfase foram: os federalistas (19); o Governo (18); castilhistas (14) e o Imperador (12). Os demais tiveram menor ênfase, mas chegaram a ser citados pelos alunos. Fragmento de narrativa:

Para defender o governo havia os seguidores de Júlio de Castilhos, eram os castilhistas.

Os federalistas eram contra o governo e eram chefiados por Silveira Martins, queriam combater o governo de Floriano Peixoto, e os castilhistas eram a favor do governo de Marechal Floriano Peixoto. (Marcos, 10 anos)

Os alunos destacam alguns personagens pessoais usados tanto na narrativa do manual didático como nas narrativas da professora. Os personagens citados com maior ênfase foram: Marechal Deodoro da Fonseca (18), Marechal Floriano Peixoto (17) e o Coronel Ernesto Gomes Carneiro (8). Os demais foram citados com menor ênfase pelos alunos. Cito como exemplo de narrativa:

O primeiro presidente Mal. Deodoro da Fonseca ele governava de modo semelhante como um imperador.

Depois de dois anos Mal. Deodoro da Fonseca acabou abandonando a Presidência e assumiu o lugar o Mal. Floriano Peixoto.

Quando começaram os combates dos federalistas o Ernesto Carneiro defendeu a Lapa por 26 dias e logo depois acabou morrendo. (Helena, 9 anos)

Tendo identificado os marcadores das narrativas dos alunos e da validade do conteúdo histórico, procurei observar os níveis apresentados nas tramas das narrativas dos alunos. Após análise, obtive diferentes níveis em relação às tramas das narrativas, sendo que o predomínio foi para as narrativas fragmentadas (12); 06 foram consideradas emergentes, embora com hiatos; 06 apresentaram ideias soltas e houve 01 ideia fragmentada não centrada na Revolução Federalista.

Narrativas emergentes, embora com hiatos - 6 (seis) narrativas assumiram a forma de narrativa emergente, com hiatos temporais. Apresentam uma contextualização, alguns acontecimentos, embora com algumas lacunas, no decorrer da construção da narrativa. Fragmento de narrativa: 
Deodoro da Fonseca, ele governava de modo semelhante ao de um imperador e o povo estava descontente com ele. Foi embora para sempre e quem ficou em seu lugar foi Marechal Floriano Peixoto, que também teve um período agitado. Em 1893 explodiu a revolução federalista no Rio Grande do Sul. E os federalistas, chefiados por Silveira Martins, que queria combater o governo de Floriano Peixoto.

Quando os federalistas começaram seus ataques, Ernesto Carneiro estava defendendo a Lapa por até 26 dias e foi ferido pelos federalistas, logo depois ele acabou morrendo. (Inês, 10 anos)

Narrativas fragmentadas - 12 (doze) narrativas assumiram a forma de narrativa fragmentada, pois embora apresentem uma contextualização, anunciem alguns acontecimentos do contexto proposto e apresentem alguns marcadores históricos, fazem-no de forma compartimentada. Exemplo de narrativa:

A Revolução Federalista aconteceu porque a Proclamação da República não deixou o País em paz.

E houve muita agitação pelo próprio Partido Republicano.

E um motivo do grande descontentamento era o Marechal Deodoro da Fonseca, que queria mandar no País inteiro sozinho, igual ao de imperador.

Dois anos se passaram que Deodoro da Fonseca comandava o País e depois assumiu seu lugar o seu vice, Marechal Floriano Peixoto.

Depois Floriano Peixoto era em um período muito agitado.

Depois, em 1893, se explodiu a Revolução Federalista no Rio Grande do Sul.

E os federalistas, que eram chefiados por Silveira Martins, que tinha um objetivo de combater o governo de Marechal Floriano Peixoto, que queriam que o Floriano Peixoto governado por menos império. (Vitor, 10 anos)

Narrativas soltas - alguns alunos, 6 (seis), produziram narrativas sob a forma de ideias soltas. Eles anunciam alguns acontecimentos, porém estes figuram como fatos isolados, não apresentando uma trama, não chegando a ser uma narrativa histórica. Fragmento de narrativa:

O governo fez que o País ficasse mais briguento, mas por isso tinha que fazer muito trabalho, com isso o País ficou bem alejado [sic].

A Revolução Federalista ficou muitos anos governando na paz de revolução, nós batíamos recorde.

Os presidentes queriam só governar, não queriam saber de outras coisas.

Mas o governo de Mal. Floriano Peixoto ficasse bem melhor que os outros e ninguém queria saber de fazer outras coisas mais interessantes, como tirar férias, mas isso não importava, eles ficavam só brigando por causa que queria mandar. 
As pessoas antigamente eles só sabiam brigar e o resto só sabiam ficar alegre. (Ana, 10 anos)

Como o predomínio foi para as narrativas fragmentadas, isto pode indicar, no dizer de Schmidt ${ }^{20}$, a necessidade do desenvolvimento de um novo tipo de cognição histórica, pautado em novas concepções da aprendizagem histórica ou do que é o «aprender a história», tomando como ponto de partida as ideias prévias dos alunos e os pressupostos e princípios da educação histórica, os quais são fundamentados na própria ciência da história.

\section{ALGUMAS CONSIDERAÇÕES FINAIS}

Os alunos, de modo geral, narraram o passado sem fazer relação com o presente; nenhum aluno perspectivou ações futuras, evidenciando que essas narrativas constituíram um sentido histórico do passado pelo passado.

Nesse sentido, o aprendizado histórico teria possibilitado aos alunos o simples adquirir de conhecimentos do passado, na perspectiva de Rüsen, pois, para este autor, o aprendizado histórico

implica muito mais que o simples adquirir de conhecimentos do passado e a expansão do mesmo. Visto como um processo pelo qual as competências se adquirem progressivamente, emerge como um processo de mudança de formas estruturais por meio das quais tratamos e utilizamos as experiências e conhecimentos da realidade passada, passando de formas tradicionais de pensamento para o pensamento genético ${ }^{21}$.

O aprendizado histórico desses alunos estaria mais próximo das formas tradicionais de pensamento histórico. Além disso, a professora, ao privilegiar em suas aulas narrativas na perspectiva da historiografia tradicional paranaense, estaria, em parte, possibilitando a constituição de uma consciência histórica do tipo tradicional, pois, na perspectiva de Rüsen ${ }^{22}$, a consciência histórica tradicional é a que articula as tradições e relembra as origens que constituem a vida no presente, funcionando, em parte, para manter vivas essas tradições, e o passado é a referência para o presente.

Esse jeito de os alunos produzirem suas narrativas indica, do ponto de vista didático, que a aula de História precisa ser modificada, pois, segundo Barca ${ }^{23}$, é preciso investigar as ideias prévias dos alunos, trabalhar com fontes históricas e solicitar a produção

\footnotetext{
${ }^{20}$ SCHMIDT, 2006.

${ }^{21}$ RÜSEN, 1992: 34.

${ }^{22}$ RÜSEN, 1992: 30; RÜSEN, 1993: 7.

${ }^{23}$ BARCA, 2004: 134-137.
} 
de narrativas pelos alunos, como elementos constitutivos da aprendizagem e da metodologia do ensino de história na perspectiva da Educação Histórica.

\section{BIBLIOGRAFIA}

BARCA, Isabel (2004) - Aula Oficina: do Projecto à Avaliação. In BARCA, Isabel, org. - Para uma Educação Histórica com Qualidade: Actas das IV Jornadas Internacionais de Educação Histórica. Braga: CIEd/Universidade do Minho; Instituto de Educação e Psicologia/Universidade do Minho, p. 131-144.

(2005) - Educação histórica: uma nova área de investigação? In NETO, José Miguel Arias, org. — Dez anos de pesquisas em ensino de história. VI Encontro Nacional de Pesquisadores de Ensino de História. Londrina: AtritoArt, p. 15-25.

(2006) - A construção de narrativas históricas: perspectivas de consciência histórica dos jovens portugueses. In Anais do Encontro Nacional dos Pesquisadores do Ensino de História: Novos Problemas e Novas Abordagens. Belo Horizonte: Faculdade de Educação, Universidade Federal de Minas Gerais.

BARCA, Isabel; GAGO, Marília (2001) - Aprender a pensar em história: um estudo com alunos do $6 .^{\circ}$ ano de escolaridade. «Revista Portuguesa de Educação», vol. 14, n. ${ }^{\circ}$ 1, p. 239-261.

BOGDAN, Robert C.; BIKLEN, Sari Knopp (1994) - Investigação qualitativa em educação. Porto: Porto Editora.

CARRETERO, Mario; JACOTT, Liliana (1997) - História e relato. In CARRETERO, Mario - Construir e ensinar as ciências sociais e a história. Porto Alegre: Artes Médicas, p. 87-101.

HUSBANDS, Chris (2003) - What is history teaching?: language, ideas, and meaning in learning about the past. Buckingham: Open University Press.

LEE, Peter (2001) - Progressão da compreensão dos alunos em história. In BARCA, Isabel, org. - Perspectivas em Educação Histórica. Actas das Primeiras Jornadas Internacionais de Educação Histórica. Braga: CEEP/Universidade do Minho, p. 13-27.

(2005) - Putting principles into practice: understanding History. In DONOVAN, M. Suzanne; BRANSFORD, John D., eds. - How students learn: History, Mathematics and Science in the classroom. Washington, D. C.: The National Academies Press, p. 31-78.

RÜSEN, Jörn (1992) - El desarrollo de la competencia narrativa en el aprendizaje histórico: una hipótesis ontogenética relativa a la conciencia moral. «Propuesta Educativa», ano 4, n. ${ }^{\circ}$. (1993) - Experience, interpretation, orientation: three dimensions of historical learning. In DUVENAGE, Peter, ed. - Studies in metahistory. Pretoria: Human Sciences Research Council. (2001) - Razão histórica: teoria da história: fundamentos da ciência histórica. Brasília: Editora Universidade de Brasília.

SCHMIDT, Maria Auxiliadora (2006) - Perspectivas da consciência histórica e da aprendizagem em narrativas de jovens brasileiros. In Anais do Encontro Nacional dos Pesquisadores do Ensino de História: Novos Problemas e Novas Abordagens. Belo Horizonte: Faculdade de Educação, Universidade Federal de Minas Gerais.

TOPOLSKI, Jeretz (2004) - La estructura de las narrativas históricas y la enseñanza de la historia. In CARRETERO, Mario; VOSS, James, comps. - Aprender y pensar la historia. Buenos Aires: Amorrortu, p. 101-119. 



\title{
A EVIDÊNCIA AUDIOVISUAL MOBILIZADA PELA IDEIA DE INTERCULTURALIDADE NA APRENDIZAGEM HISTÓRICA DOS JOVENS ESTUDANTES PORTUGUESES A PARTIR DOS VÍDEOS DE HISTÓRIA NO YOUTUBE
}

\author{
MARCELO FRONZA*
}

Resumo: Essa investigação busca compreender as formas como os jovens estudantes fazem escolhas que mobilizam a geração de sentido histórico por meio da interculturalidade 1 a partir de evidências audiovisuais quando confrontados com vídeos de história do YouTube. Por meio de um instrumento de pesquisa, construído a partir dos princípios da investigação qualitativa ${ }^{2}$, pesquiso as ideias históricas sobre interculturalidade e evidência de jovens estudantes portugueses do ensino secundário de duas escolas da rede pública do norte de Portugal. Busco compreender como esses sujeitos inferem evidências audiovisuais quando apresentados aos conflitos presentes no processo da conquista e colonização europeia sobre os povos da América, por meio do confronto de três vídeos do YouTube sobre este tema histórico.

Palavras-chave: Educação histórica; Evidências audiovisuais; Interculturalidade; Vídeos do YouTube.

Abstract: This research aims to understand the ways in which young students make choices that mobilize the generation of making sense of history through interculturality from audiovisual evidence when confronted with YouTube history videos. Through a research tool, built on the principles of qualitative research, I research the historical ideas about interculturality and evidence of young Portuguese high school students from two public schools in the north of Portugal. I try to understand how these subjects infer audiovisual evidence when presented to the conflicts present in the process of European conquest and colonization of the peoples of America, through the confrontation of three YouTube videos about this historical theme.

Keywords: History education; Audiovisual evidence; Interculturality; YouTube videos.

\section{INTRODUÇÃO}

Nesta investigação, tenho como finalidade compreender as formas como os jovens estudantes fazem escolhas que mobilizam a geração de sentido histórico ${ }^{3}$ por meio da interculturalidade e evidências audiovisuais quando confrontados com vídeos de história do YouTube. Com isso, busco investigar processos históricos ligados à relação

\footnotetext{
* Doutor em Educação, Universidade Federal do Paraná; Mestre em História, Universidade Federal do Paraná. Professor adjunto do Departamento de História da Universidade Federal de Mato Grosso. Coordenador do Grupo Pesquisador Educação Histórica: Consciência histórica e narrativas visuais (GPEDUH/UFMT, Brasil). Investigador do Laboratório de Pesquisa em Educação Histórica (LAPEDUH/UFPR, Brasil).E-mail: fronzam08@gmail.com.

${ }^{1}$ RÜSEN, 2014; RÜSEN, 2015a.

${ }^{2}$ LESSARD-HÉBERT et al., 2005.

${ }^{3}$ RÜSEN, 2015a.
} 
entre interculturalidade e o novo humanismo $\mathrm{e}^{4}$ o princípio da burdening history investigado por Bodo von Borries ${ }^{5}$, que propõe que o fardo da história possa ser superado pela interpretação multiperceptivada que institui a controvérsia proporcionada pela autocrítica na teoria da história.

Este trabalho está relacionado ao projeto de pesquisa $A$ aprendizagem histórica dos jovens estudantes brasileiros e portugueses a partir das narrativas históricas visuais vinculado ao meu estágio pós-doutoral realizado no CITCEM - Centro de Investigação Transdisciplinar Cultura, Espaço e Memória na Universidade do Porto em Portugal e ao projeto de pesquisa Por uma aprendizagem histórica humanista dos jovens estudantes de ensino médio a partir das narrativas históricas visuais vinculado ao GPEDUH/UFMT e ao LAPEDUH/UFPR.

A interculturalidade parte do princípio do reconhecimento igualitário e humanista da diferença cultural ${ }^{6}$. Nesse sentido, a formação intercultural dos jovens estudantes e a produção de conhecimentos históricos na escola ou fora dela devem se basear nos critérios de cognição histórica, orientados por princípios e propósitos baseados na ciência da história ${ }^{7}$.

A intersubjetividade internaliza, nos estudantes, o processo de constituição da consciência histórica coletiva da humanidade em suas próprias biografias em relação com as dos outros no tempo e no espaço. Os princípios que regem a intersubjetividade são o diálogo e a capacidade de argumentar racionalmente, nos quais os sujeitos narram por meio suas perspectivas históricas reconhecendo como válidas as perspectivas históricas dos outros reconstruindo uma multiperspectividade humanista. Com isso, a validade da identidade histórica do sujeito é intrínseca à igualdade em relação à alteridade do outro ${ }^{8}$. É da intersubjetividade como princípio que a categoria da interculturalidade ganha sentido.

A interculturalidade parte do princípio do reconhecimento igualitário e humanista da diferença cultural que supera a compreensão etnocêntrica pautada na tolerância cedida, pelo civilizado, ao não civilizado. As lutas pelo reconhecimento estão na base dos conflitos culturais contemporâneos. Contudo, é no campo desses conflitos que as chances de comunicação intercultural se fazem valer, pois as culturas aprendem umas das outras e se modificam no relacionamento mútuo, se interpenetram, delimitam-se umas em relação às outras, combatem-se 9 .

\footnotetext{
${ }^{4}$ RÜSEN, 2014; RÜSEN, 2015b.

${ }^{5}$ BORRIES, 2018.

${ }^{6}$ RÜSEN, 2014.

${ }^{7}$ SCHMIDT, 2009.

${ }^{8}$ RÜSEN, 2015a.

${ }^{9}$ RÜSEN, 2014: 296.
} 
Isso ocorre quando se tem como princípio o reconhecimento mútuo, no qual o tempo teleológico centrado na linha quadripartite eurocêntrica ou o caleidoscópio relativista do multiculturalismo são suplantados pela reconstrução temporal policêntrica da história da humanidade. Esta reconstrução é possível no momento em que os sujeitos fazem uso de um entendimento intercultural por meio de universais antropológicos e de valores humanistas e igualitários presentes em todas as culturas humanas. Essa compreensão histórica intercultural policêntrica e, portanto, multiperspectivada, é o critério que estrutura uma formação histórica numa dimensão humanista da didática da história.

\section{INVESTIGAR AS IDEIAS DE INTERCULTURALIDADE E EVIDÊNCIA AUDIOVISUAL DE JOVENS ESTUDANTES SECUNDARISTAS PORTUGUESES A PARTIR DE VÍDEOS DE HISTÓRIA DO YOUTUBE}

Seguindo os princípios da investigação qualitativa ${ }^{10}$, pesquiso as ideias históricas sobre interculturalidade e evidência audiovisual de jovens estudantes portugueses do ensino secundário de duas escolas da rede pública do norte de Portugal por meio de um instrumento de pesquisa, quando apresentados aos conflitos presentes no processo da conquista e colonização europeia sobre os povos da América, por meio do confronto de três vídeos do YouTube sobre este tema histórico.

O público-alvo da investigação são 35 jovens estudantes, com idades entre $16 \mathrm{e}$ 17 anos (uma com 21 anos), de duas turmas do $11 .^{\circ}$ ano de duas escolas públicas, que estudam no ensino secundário nas cidades de Paredes (14 estudantes) e Santo Tirso (21 estudantes), norte de Portugal. Esses estudantes são representados neste trabalho por nomes fictícios escolhidos por eles mesmos.

A questão de investigação que fundamenta essa pesquisa é: «Que escolhas históricas fazem os jovens estudantes quando são confrontados com diferentes versões de vídeos de história do YouTube?»

O instrumento de pesquisa contém perguntas abertas e fechadas a partir de um questionário entendido como um estudo-piloto, cujo objetivo é diagnosticar como os jovens fazem escolhas históricas quando são confrontados com três versões de vídeos do YouTube sobre a História da colonização europeia sobre os povos da América.

O instrumento de pesquisa foi aplicado nas manhãs dos dias 4 e 20 de fevereiro de 2019 com a duração de 90 minutos nas aulas, mais o intervalo em Paredes e Santo Tirso, respectivamente.

O primeiro vídeo, denominado 500 anos de história do Brasil, é a versão $\mathrm{A}$, do Nostalgia, que é um dos maiores canais sobre cultura pop do Brasil. Seu criador e

${ }^{10}$ LESSARD-HÉBERT et al., 2005. 
apresentador, o designer paulista Felipe Castanhari, desenvolve vídeos educacionais de História e Ciências Naturais.

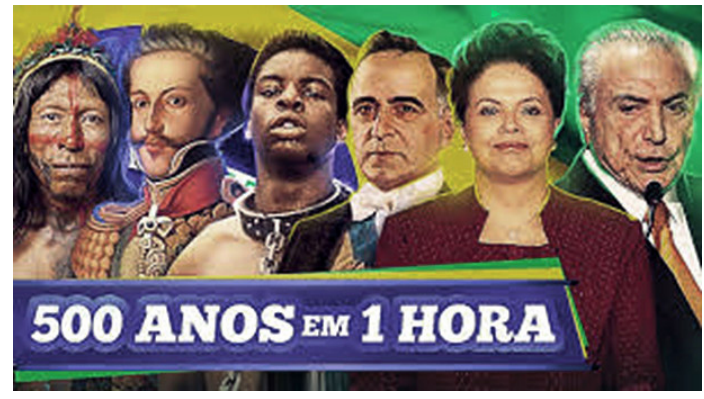

Fig. 1. Versão A: Screenshot do arquivo de vídeo Nostalgia História T1 - 500 anos em 1 hora / História do Brasil. Fonte: CASTANHARI, 2017

Os seus vídeos de História são assessorados pelo historiador Caio Vinícius, formado pela Universidade de São Paulo e seu antigo professor do Ensino Médio ${ }^{11}$. Esse vídeo possuía 6558338 visualizações em 7 de setembro de 2019.

O segundo vídeo, chamado Ciclo do Ouro, no canal Débora Aladim, é a versão B.

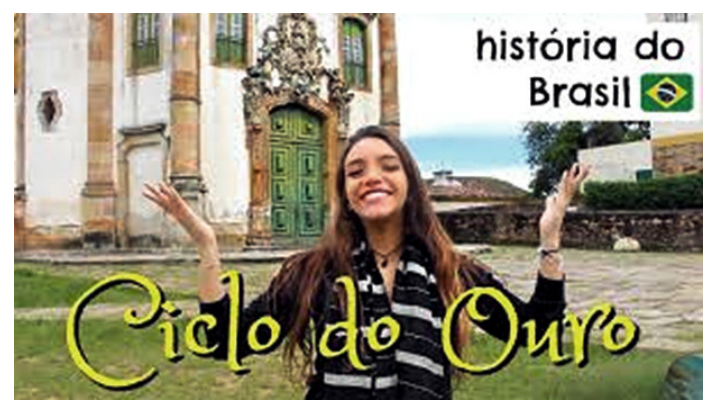

Fig. 2. Versão B: Screenshot do arquivo de vídeo Resumo de História: Ciclo do Ouro - em Ouro Preto, MG! Fonte: ALADIM, 2018

Débora Aladim é estudante de História da Universidade Federal de Minas Gerais e produz os conteúdos de seu canal, focados principalmente em dicas de estudos para o Exame Nacional do Ensino Médio (ENEM) e vestibulares, além de abordar fatos e curiosidades da vida universitária. Figura entre os cinco maiores canais educacionais do YouTube brasileiro ${ }^{12}$. Esse vídeo possuía 227259 visualizações em 7 de setembro de 2019.

O terceiro vídeo, chamado O que foi a Revolta dos Búzios?, é a versão C. O canal PhCôrtes foi criado em 2015 por Pedro Henrique Côrtes, mais conhecido como PhCôrtes, que abriu um dos seus vídeos para protestar contra a morte de cinco jovens

\footnotetext{
${ }^{11}$ ROCHA, 2018.

${ }^{12}$ ROCHA, 2018.
} 
negros no Rio de Janeiro com apenas 13 anos com as seguintes frases: "Você vive no Brasil? É jovem? É negro? Vive em favelas ou bairros periféricos? Sim, eu queria ser mais delicado ao dizer isso, mas você tem 25 vezes mais chance de ser assassinado do que jovens brancos brasileiros!»

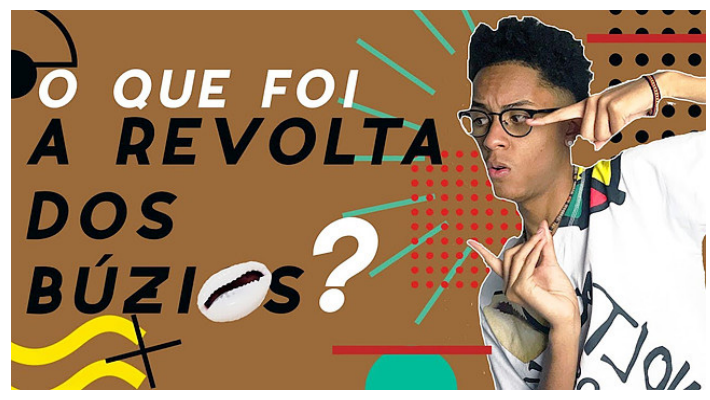

Fig. 3. Versão C: Screenshot do arquivo de vídeo O que Foi a Revolta dos Búzios - Meus Heróis Negros Brasileiros. Fonte: CÔRTES, 2018

PhCôrtes, em 23 de novembro de 2015, começa o quadro Meus heróis negros inspirado, entre outros, pelos vídeos de história do canal Nostalgia de Felipe Castanhari, por obras historiográficas e histórias em quadrinhos sobre história do povo afro-brasileiro. Esse vídeo possuía 3106 visualizações no dia 7 de setembro de 2019.

As perguntas investigativas foram inspiradas em questões presentes em minha tese de doutorado $A$ intersubjetividade e a verdade na aprendizagem histórica de jovens estudantes a partir das histórias em quadrinhos ${ }^{13}$ e nas ideias da teoria da consciência histórica relativas à interculturalidade propostas por Jörn Rüsen ${ }^{14} \mathrm{e}$ têm como objetivo diagnosticar as ideias históricas que os jovens entendem como passíveis de geração de sentido de orientação temporal ${ }^{15}$. Com a finalidade de um recorte, abordei as questões que mais geraram respostas de cunho intercultural. As questões a serem abordadas são:

Q6. A partir das versões $A, B, e C$, quais as situações do passado que você acha mais significativas? Por quê??

Q7. A partir das versões $A, B, e C$, quais os personagens do passado você acha mais relevantes? Por quê?

Q11. Que consequências para o presente e para o futuro da humanidade tiveram as relações entre europeus e os povos da América ocorridas durante a colonização?

\footnotetext{
${ }^{13}$ FRONZA, 2012.

${ }^{14}$ RÜSEN, 2014.

${ }^{15}$ RÜSEN, 2007.
} 
As respostas a essas questões serão abordadas a partir de uma estrutura em que as escolhas das versões de vídeos do YouTube realizadas pelos jovens investigados apontam em direção a determinadas categorias surgidas na redução dos dados empíricos e vinculadas às evidências audiovisuais. Informo que para esse texto nem todas as respostas e categorias serão apresentadas; somente aparecerão aqui as consideradas por mim mais relevantes para esse trabalho. Considerando os dados empíricos extraídos a partir das respostas às questões investigadas (Q6, Q7 e Q11), constato que a compreensão dos jovens estudantes secundaristas portugueses sobre as categorias da interculturalidade e de evidência não são unívocas e podem ser apresentadas de forma multiperpectivada.

\section{Evidência enquanto interpretação econômica e política da história}

\section{Versão B}

Q6. Situações do passado

A versão $B$, pois foi muito importante para Portugal, uma vez que conseguiu ultrapassar a situação financeira. (El Presidente, M, 17 anos, Paredes)

\section{Escolha não explícita de versão em vídeo do YouTube}

Q11. Relações entre europeus e os povos da América

Evolui a economia europeia devido a sua exploração. (Costibias, M, 17 anos, Paredes) Não se desenvolveu nos países na América inferiorizando as colônias. (João Félix, F, 16 anos, Paredes)

Uma grande vantagem que a América tinha, e que contribuiu para o desenvolvimento da Europa, foi a produção de café, açúcar, tabaco e algodão e, também, o ouro. (Skinny C, F, 16 anos, Santo Tirso)

Toda a colonização teve consequências positivas e negativas, trazendo bons lucros para os países colonizadores europeus e um fraco desenvolvimento para o Brasil, que era visto como colônia e apenas um espaço para obter riqueza. (Karl Marx, M, 16 anos, Santo Tirso)

Eu sei responder a isso, mas não tenho muito tempo. Portanto, afeta o presente e o futuro na política, na economia dos países da América e da sociedade, tanto europeia como dos povos americanos. (Catriona Mckenzie, F, 16 anos, Santo Tirso)

Entre as respostas dos estudantes predominaram interpretações de caráter econômico e, em menor medida, político, relativas a exploração colonial do Brasil por Portugal, tal como expresso por El Presidente, que considera que a versão B explica sobre os lucros obtidos pela metrópole em relação à colônia americana. Quanto aos 
jovens que responderam as consequências para o presente e o futuro relações entre europeus e os povos da América a exploração colonial também foi relevante. É importante destacar que as interpretações de Costibias, João Félix, Skinny C e Karl Marx estão focadas em processos históricos passados. No caso do último jovem a exploração econômica gerava riqueza para Portugal e pouco desenvolvimento para o Brasil devido ao seu caráter de colônia, enquanto a penúltima estudante considerava a abundância de recursos agrícolas da América uma positividade para seus povos. No entanto, mesmo que de maneira pouco clara, Catriona Mckenzie defende que as relações entre europeus e os povos americanos afetam o presente e o futuro desses povos dando indícios de uma geração de sentido de orientação temporal ${ }^{16}$.

\section{Evidência enquanto interpretação cultural da história}

\section{Escolha não explícita de versão em vídeo do YouTube}

Q11. Relações entre europeus e os povos da América

Consequências na cultura desses mesmos países. (Ragnar Rodrigues, M, 16 anos, Paredes)

Ragnar Rodrigues foi o único jovem que explicitamente destacou que as relações entre europeus e americanos gerou consequências culturais para a formação dos respectivos países. Apesar de não aprofundar essa resposta, é perceptível que elementos da cultura histórica mobilizam as ideias de evidência dos estudantes no caso de Portugal.

\section{Evidência enquanto interculturalidade}

A interculturalidade foi uma das categorias que surgiram com força quando foi perguntado aos jovens quais as situações do passado que consideram mais significativas. Foi também uma das categorias que mais mobilizaram diferentes escolhas entre as versões de vídeos do YouTube.

\section{Versão A}

Q6. Situações do passado

A versão A, pois explica as histórias de dois países (Portugal e Brasil), ensinando-nos que estes dois estão, de alguma forma, relacionados. (Cherryl Blossom, F, 16 anos, Paredes) 
A resposta de Cherryl Blossom é claramente de teor intercultural, pois entende que a versão A ensina os jovens sobre a história entre Brasil e Portugal de um modo relacional e interdependente.

\section{Versão B}

Q6. Situações do passado

[A versão] B, pois fala do ouro encontrado no Brasil e como Portugal o desperdiçou. (Palmira, F, 17 anos, Santo Tirso)

A versão $B$, porque explica como era a extração do ouro e a influência de Portugal e como era a situação vivida no Brasil com a procura do ouro e [a] opressão do rei para obter o ouro do Brasil (Isabel, F, 21 anos, Paredes)

Já Palmira e Isabel compreendem que a versão B apresenta uma explicação histórica sobre a relação de exploração econômica do Brasil por Portugal. Elas indicam que as relações interculturais entre Brasil e Portugal eram desiguais.

\section{Versão C}

Q6. Situações do passado

Acho mais significativa a situação que o PhCôrtes falou sobre os negros brasileiros e do assunto racismo, pois é um assunto que dura até os dias de hoje. (Flor, F, 17 anos, Santo Tirso)

Mas a explicação histórica de Flor, que defendeu que a versão $\mathrm{C}$ apresentava as situações mais significativas do passado, identificou uma interculturalidade mais sofisticada ao trazer as problemáticas da condição dos afro-brasileiros e da persistência do racismo para o presente da práxis social contemporânea. Segundo Borries ${ }^{17}$, a pluralidade das formas de geração de sentido de orientação histórica para a vida é construída por meio de narrativas identitárias mediadas pelo antagonismo expresso em histórias difíceis em conflito e estratégias de reconciliação mútua com vista a perspectivas de futuro.

\section{Evidência enquanto antagonismo social}

Esses jovens estudantes apresentam uma abordagem que compreende a evidência enquanto antagonismo social demarcando uma clivagem violenta nas relações culturais entre europeus e os povos da América.

\footnotetext{
${ }^{17}$ BORRIES, 2018.
} 


\section{Escolha não explícita de versão em vídeo do YouTube}

Q6. Situações do passado

A escravização dos negros africanos e de índios americanos, pois explica a presente discriminação social que existe na atual sociedade. (Indiga, F, 16 anos, Paredes)

Q11. Relações entre europeus e os povos da América

Os europeus oprimiam totalmente os povos colonizados tendo consequências a níveis sociais. (Indiga, F, 16 anos, Paredes)

Tiveram consequências como a continuidade do racismo. (Happy, F, 17 anos, Paredes)

Trouxe muitas coisas más como o racismo e a discriminação. (Rakan, M, 16 anos, Paredes)

A relação entre os povos teve como consequência o racismo que existe entre os povos. (Eça de Queirós, M, 16 anos, Santo Tirso)

Indiga, Happy, Rakan e Eça de Queirós apontam que a discriminação e o racismo são processos resultantes da escravização de negros africanos, dominação sobre os indígenas e da colonização europeia, sendo geradores do antagonismo social presente na sociedade americana, especialmente a brasileira, mas também na portuguesa. Portanto, para esses quatro estudantes a escravização e a colonização da América influenciam de modo traumático os problemas que ainda afligem Brasil e Portugal no século XXI.

\section{Versões A, B e C}

Q6. Situações do passado

A partir das versões $A, B$ e C a situação do passado que eu achei mais significativa foi a abolição/fim da escravidão, pois a desigualdade é algo que não me agrada. Além disso, acho injusto naquela época as classes mais baixas serem escravizadas por povos superiores. (Leonor, F, 17 anos, Santo Tirso)

Q7. Personagens do passado

Os indios e os escravos, pois lutavam por sua liberdade. (Isabel, F, 21 anos, Paredes) As personagens mais relevantes, na minha opinião, são os escravos, por terem, a partir de uma revolta, alcançado a liberdade. (Leonor, F, 17 anos, Santo Tirso)

Leonor entende que a escravidão alimentou a injustiça e a desigualdade durante a colonização portuguesa no Brasil. Também defende, junto com Isabel, que os escravizados 
conquistaram por eles mesmos sua liberdade, pois se revoltaram ao longo da histórica da colonização da América pelos europeus. Apresentam, portanto, explicações que geram sentido de orientação temporal em seu processo de aprendizagem histórica. Segundo Bodo von Borries ${ }^{18}$, só é possível aprender história pela inclusão antagônica e multiperspectivada de «histórias difíceis» por meio de narrativas temáticas significativas que levem em conta a dialética negativa entre a «concretude da identidade» de uma comunidade e a «pluralidade multiperspectivada» do outro clivado nessa mesma comunidade.

\section{Evidência enquanto ética da responsabilidade}

Quando perguntados sobre quais os personagens do passado mais relevantes narrados pelas versões em relação à colonização dos povos americanos, três jovens estudantes identificaram uma ética da responsabilidade para apresentar os sujeitos históricos que fornecem um sentido para a história narrada.

\section{Escolha não explícita de versão em vídeo do YouTube}

Q7. Personagens do passado

$O$ «tira dentes» [Tiradentes], pois mostra que são sempre as pessoas com menor poder que sofrem as consequências de atos cometidos por outros. (Cherryl Blossom, F, 16 anos, Paredes)

«Tira dentes», uns pagam pelos outros. (Veronica Lodge, F, 16 anos, Paredes)

\section{Versão C}

Q7. Personagens do passado

A versão C. A personagem relevante foi João de Deus e os seus outros amigos que assumiram as culpas e morreram. (Rakan, M, 16 anos, Paredes)

A ideia predominante é que tanto Tiradentes (indicado por Cherryl Blossom e Veronica Lodge) quanto João de Deus (apontado por Rakan) assumiram a responsabilidade pelas insurreições que outros membros dos grupos de suas revoltas não o fizeram. Aqui a dimensão ética da cultura histórica, expressa por artefatos como vídeos do YouTube, perspectiva as formas de explicar e os valores dos jovens na sua práxis social ${ }^{19}$.

\footnotetext{
${ }^{18}$ BORRIES, 2018.

${ }^{19}$ RÜSEN, 2007.
} 


\section{Evidência enquanto julgamento moral}

Essa categoria relativa ao julgamento moral foi explicitada a partir da dimensão ética da cultura histórica presente nas respostas de alguns jovens estudantes quando confrontados com questões relativas às situações significativas do passado e sobre as relações entre europeus e os povos da América.

\section{Escolha não explícita de versão em vídeo do YouTube Q7. Personagens do passado}

Índios e pretos, pois mostra o quão cruéis foram os brasileiros e portugueses em torná-los escravos. (Marlene, F, 17 anos, Santo Tirso)

\section{Q11. Relações entre europeus e os povos da América}

Chegar à conclusão de quanto mal a humanidade já causou entre si. (Rosdrey of Rivia, M, 16 anos, Santo Tirso)

Marlene entendeu como relevantes para a histórica da colonização da América os africanos, afro-brasileiros e indígenas. No entanto, destacou a crueldade de portugueses e brasileiros para com esses seres humanos. Essa jovem interpreta a história a partir de um julgamento moral sobre as práticas desumanas realizadas por luso-brasileiros para construírem seu modo de vida no Brasil colonial. Já Rosdrey of Rivia desenvolveu uma concepção moral absolutizante ao afirmar que a humanidade causou mal a si mesma. Novamente a dimensão ética da cultura histórica configura o modo de interpretar a história desses jovens ${ }^{20}$, um apontando que a crueldade está presente nos processos históricos e, outro, defendendo que o mal é intrínseco aos seres humanos. Para ambos a moralidade rege os rumos da história da humanidade na forma de permanência temporal.

\section{Evidência enquanto mudança histórica}

A categoria da mudança histórica surgiu somente nas respostas à questão sobre as consequências das relações entre europeus e os povos da América para o presente e o futuro. Mesmo existindo alguns jovens que apresentavam respostas focadas somente no passado, ainda assim muitos estudantes apresentaram relações de temporalidade e orientação histórica para além de casos pretéritos.

\footnotetext{
${ }^{20}$ RÜSEN, 2007.
} 


\section{Escolha não explícita de versão em vídeo do YouTube}

Q11. Relações entre europeus e os povos da América

Ambos os povos perceberam os erros e melhoraram tudo. (Veronica Lodge, F, 16 anos, Paredes)

Perceber os erros e melhorar o futuro. (Jack, F, 16 anos, Paredes)

Eles agora sabem que não podem cometer os mesmos erros do passado. (Kurt Girl, F, 16 anos, Paredes)

Indico aqui três dos jovens que apresentaram respostas voltadas para a mudança histórica de modo explícito. Veronica Lodge e Jack afirmam que europeus e americanos perceberam erros cometidos no passado e «melhoraram tudo» ou o «futuro», ou seja, para elas houve ou haverá uma reordenação radical das relações entre esses sujeitos já apontando para uma visão utópica da sociedade ${ }^{21}$.

\section{Escolha não explícita de versão em vídeo do YouTube}

Q11. Relações entre europeus e os povos da América

Deu origem ao racismo existente agora e, também, contribuiu para a relação entre os povos. Logo, houve a mistura de culturas e diferentes maneiras de pensar. (Milena, F, 17 anos, Santo Tirso)

A resposta de Milena a quais seriam as consequências para a contemporaneidade e para o futuro das relações entre europeus e os povos da América é uma das mais complexas no que diz respeito a categoria da interculturalidade em uma perspectiva de mudança histórica, pois, tal como Rüsen ${ }^{22}$, defende que essa categoria diz respeito ao inter-relacionamento conflitivo e dialógico entre as culturas em um difícil, mas necessário, processo de aprendizagem de reconhecimento e reconciliação mútuos. É possível que essa concepção leve a próxima categoria encontrada nos dados empíricos investigados.

\section{Evidência enquanto possibilidade utópica de reconciliação}

Aqui a interculturalidade se relaciona com a ideia de uma evidência enquanto possibilidade utópica de reconciliação e reconhecimento entre diferentes culturas.

\footnotetext{
${ }^{21}$ RÜSEN, 2007.

${ }^{22}$ RÜSEN, 2014.
} 


\title{
Escolha não explícita de versão em vídeo do You'Tube
}

Q11. Relações entre europeus e os povos da América

\begin{abstract}
Ambos os povos perceberam os erros que devem evitar no futuro e como melhorar a sua relação futura. (Cherryl Blossom, F, 16 anos, Paredes)

Nascimento de novas nações e formação de novas mentalidades. (Mário Leal, M, 16 anos, Paredes)

O seu desenvolvimento e mais tarde, também, com uma possível aliança com a exploração do Brasil, Portugal abre as portas a uma nova cultura que muda também a maneira das coisas. (Magneto, M, 17 anos, Santo Tirso)
\end{abstract}

Cherryl Blossom entende que brasileiros e portugueses já perceberam os erros cometidos no passado e têm condição de evitá-los no futuro. Com isso, para esses jovens, é possível melhorar progressivamente a relação entre ambos os povos. Mário Leal apontou que a relação entre europeus e os povos da América transformaram suas sociedades a ponto de formar novas nações, mas principalmente novas formas de pensar as relações interculturais. A resposta de Magneto é mais complexa, pois para ele uma das consequências dessa relação cultural foi o desenvolvimento por meio de uma aliança política entre brasílicos e portugueses na exploração das riquezas e dos povos indígenas e africanos no Brasil. No entanto, esse antagonismo social gerou uma nova cultura e uma mudança nas relações sociais dessas comunidades. Por isso, a dimensão utópica da cultura histórica da humanidade aparece na forma de pensar a interculturalidade de alguns jovens ${ }^{23}$.

\section{CONSIDERAÇÕES FINAIS}

Os resultados da investigação nos permitem compreender que as evidências audiovisuais permitem aos jovens revelar critérios vinculados a cognição histórica situada que avaliam as maneiras pelas quais esses jovens compreendem a interculturalidade a partir de experiências passadas e que fornecem valores e significados históricos que fazem sentido a sua vida prática e orientam a formação histórica como um processo criativo de autoconhecimento e de alteridade.

Investigar a relação da construção de evidências e das concepções de interculturalidade dos jovens com as formas narrativas específicas geradas por vídeos de história do YouTube permite confirmar a hipótese de que os jovens fazem escolhas históricas quando são confrontados com evidências audiovisuais.

\footnotetext{
${ }^{23}$ RÜSEN, 2007.
} 
No entanto, ainda é necessário aprofundar as compreensões de caráter epistemológico relativas a relação mobilizadas pelos jovens estudantes em relação à interculturalidade. Para isso, um aprofundamento das análises empíricas em relação ao debate teórico e metodológico com essa categoria a partir de Jörn Rüsen ${ }^{24}$ e Júlia Castro ${ }^{25}$ contribuirá muito para essa investigação.

Esses resultados constatam a hipótese de que as pesquisas relativas à evidência histórica ${ }^{26}$ permitem concluir que é possível entender como válida a ideia de evidência audiovisual quando inferida no confronto narrativo de artefatos da cultura histórica como os vídeos do YouTube que mobilizam, nos jovens portugueses, escolhas pautadas na geração de sentido de orientação histórica a partir da dimensão sofrimento humano ${ }^{27}$. A interculturalidade é um processo histórico da humanidade que é fruto do sofrimento gerado pelo antagonismo social presente nas relações humanas e que demarca a forma de pensar dos jovens estudantes. As evidências audiovisuais são condutoras para a produção de narrativas interculturais que os estudantes constroem para si na relação que mantêm com a escola e na orientação temporal da práxis social.

\section{REFERÊNCIAS}

ALADIM, Débora (2018) - Resumo de História: Ciclo do Ouro - Em Ouro Preto, MG! (Débora Aladim). Disponível em $<$ https://www.youtube.com/watch?v=7tMLDOID9rw\&t=709s $>$. [Consulta realizada em 15/10/2019].

ASHBY, Rosalyn (2003) - O conceito de evidência histórica: exigências curriculares e concepções de alunos. In BARCA, Isabel, org. - Educação histórica e museus. Actas das Segundas Jornadas Internacionais de Educação Histórica. Braga: CIEd/Universidade do Minho, p. 37-57.

(2006) - Desenvolvendo um conceito de evidência histórica: as idéias dos estudantes sobre testar afirmações factuais singulares. «Educar», Especial, p. 151-170.

BORRIES, Bodo von (2018) - Lidando com histórias difíceis. In SCHMIDT, Maria Auxiliadora; FRONZA, Marcelo; NECHI, Lucas Pydd, coord. - Jovens e consciência histórica. Curitiba: W. A. Editores, p. 33-54.

CASTANHARI, Felipe (2017) - Nostalgia História T1 - 500 anos em 1 hora/História do Brasil. Disponível em <https://www.youtube.com/watch?v=q7E4XrfGGnE\&t=98s >. [Consulta realizada em $15 / 10 / 2019]$.

CASTRO, Júlia (2007) - Perspectivas de alunos do ensino secundário sobre a interculturalidade e o conhecimento histórico. «Currículo sem Fronteiras», vol. 7, n. ${ }^{\circ} 1$ (jan.-jun.), p. 28-73.

CÔRTES, Pedro Henrique (2018) - O que foi a Revolta dos Búzios - Meus Heróis Negros Brasileiros. PhCôrtes. Disponível em <https://www.youtube.com/watch?v=MsG8T_Bfypk\&t=598s >. [Consulta realizada em 15/10/2019].

FRONZA, Marcelo (2012) - A intersubjetividade e a verdade na aprendizagem histórica de jovens estudantes a partir das histórias em quadrinhos. Curitiba: Universidade Federal do Paraná. Tese de doutorado.

\footnotetext{
${ }^{24}$ RÜSEN, 2014.

${ }^{25}$ CASTRO, 2007.

${ }^{26}$ SHEMILT, 2009; ASHBY, 2003; ASHBY, 2006; SIMÃO, 2007; SIMÃO, 2015; VIEIRA, 2015.

${ }^{27}$ RÜSEN, 2014.
} 
LESSARD-HÉBERT, Michelle; GOYETTE, Gabriel; BOUTIN, Gérald (2005) - Investigação qualitativa: fundamentos e práticas. Lisboa: Instituto Piaget.

ROCHA, Breno Lacerda (2018) - Narrativas históricas digitais: uma análise de vídeos de história no YouTube. Cuiabá: UFMT. Trabalho de conclusão de curso de licenciatura em História.

RÜSEN, Jörn (2007) - História viva: Teoria da história III: formas e funções do conhecimento histórico. Brasília: UnB.

(2014) - Cultura faz sentido: orientações entre o ontem e o amanhã. Petrópolis: Vozes.

(2015a) - Formando a consciência histórica - para uma didática humanista da história. In RÜSEN, Jörn - Humanismo e Didática da História. Org. Maria Auxiliadora Schmidt et al. Curitiba: W. A. Editores, p. 19-42.

(2015b) - Teoria da História. Uma teoria da história como ciência. Curitiba: Editora da UFPR.

SCHMIDT, Maria Auxiliadora (2009) - Cognição histórica situada: que aprendizagem é esta? In SCHMIDT, Maria Auxiliadora; BARCA, Isabel, coord. - Aprender História: perspectivas da Educação Histórica. Ijuí: Unijuí, p. 21-50.

SHEMILT, Denis (2009) - Drinking an ocean and pissing a cupful: How adolescents make sense of history. In SYNCOX, Linda; WILSCHUT, Arie, coord. - National history standards: The problem of the canon and the future of teaching History. Charlotte, North Carolina: IAP.

SIMÃO, Ana Catarina Gomes (2007) - A construção da evidência histórica: concepções de alunos do $3 .^{\circ}$ ciclo do ensino básico e secundário. Braga: Universidade do Minho. Tese de doutorado.

(2015) - Repensando a evidência histórica na construção do conhecimento histórico. «Diálogos», vol. 19, n. ${ }^{\circ} 1$ (jan.-abr.), p. 181-198.

VIEIRA, Jucilmara Luiza Loos (2015) - Cultura histórica e cultura escolar: diálogos entre a iconografia pictórica histórica e o ensino de história. Curitiba: Universidade Federal do Paraná. Dissertação de mestrado. 


\title{
PARA CONHECERA EDUCAÇÃO HISTÓRICA: UM INVENTÁRİO A PARTIR DA TEORIA DA HISTÓRIA SOBRE A EDUCAÇÃO HISTÓRICA EM PORTUGAL
}

\author{
THIAGO AUGUSTO DIVARDIM DE OLIVEIRA*
}

Resumo: Esse artigo insere-se no campo da Didática da História, discutida no âmbito da teoria e filosofia dessa ciência. No Brasil, o campo da educação histórica foi influenciado pelas discussões portuguesas, que por sua vez foram influenciadas pela Inglaterra. Aqui e na Europa além da utilização do conceito consciência histórica (como contribuição da teoria da História alemã), comum em diversos outros países, discussões a respeito da progressão, avanço, mudança do pensamento histórico, do desenvolvimento de competências, ou ainda do processo formativo da consciência histórica têm se tornado presentes e gerado debates. Com o objetivo de compreender a historicidade dessas concepções, o presente artigo propõe um inventário ${ }^{1}$ adentrando os campos da teoria e filosofia da história. As fontes analisadas nesse propósito configuram recortes das pesquisas realizadas na tese A Formação Histórica (Bildung) como Princípio da Didática da História no Ensino Médio: Teoria e Práxis² e, para o presente texto foram inventariados parte dos artigos publicados pela professora Isabel Barca (Universidade do Minho, Portugal) entre os anos 2000 e 2012. Os resultados foram organizados em duas categorias temáticas: no primeiro tema foi possivel perceber que entre os autores mais citados aparecem filósofos de inspiração lógica (analítica e/ou positivista) da filosofia crítica anglo-americana em diálogo com autores das ciências da educação (no que diz respeito a proposta da mudança conceptual); já no segundo tema ocorrem abordagens que privilegiam a contribuição do filósofo e historiador Jörn Rüsen a respeito da consciência histórica, mesmo sem abandonar alguns referenciais e influências anteriores (característicos da filosofia crítica). A discussão a partir dos textos da educação histórica em Portugal poderá auxiliar a compreensão sobre conceitos como competências, progressão, e ainda, sobre aproximações entre História e Psicologia no que diz respeito aos conceitos substantivos e de segunda ordem. Além disso, sobre como é possível perceber as influências da teoria e filosofia da história na maneira como se analisam dados empíricos como explicações e/ou narrativas de estudantes. Espera-se ter contribuído com elementos que darão historicidade aos debates do campo da didática da História pensada em relação intrínseca com a teoria da História. O que poderá contribuir com professores(as)-pesquisadores(as) que busquem referências no campo da educação histórica no âmbito ibero-americano, possibilitando perceber características próprias de cada grupo, assim como seus diálogos e contribuições aos debates da didática da História.

Palavras-chave: Educação histórica; Didática da História; Consciência histórica.

Abstract: This article is part of the field of Didactics of History, discussed within the scope of the theory and philosophy of this science. In Brazil, the field of historical education was influenced by Portuguese discussions, which were influenced by England. In Brazil and Europe, in addition to the use of the concept of historical awareness (as a contribution of German history theory), common in several other countries, discussions about progression, advancement, change in historical thinking, skills development, or even the training process of historical consciousness have become present and have generated debates.

\footnotetext{
* Instituto Federal do Paraná (Campus Curitiba); Pesquisador do LAPEDUH/UFPR. E-mail: thiagodivardim@gmail.com. ${ }^{1}$ GRAMSCI, 1984.

${ }^{2}$ OLIVEIRA, 2017a.
} 
In order to understand the historicity of these conceptions, this article proposes an inventory ${ }^{3}$ entering the fields of the theory and philosophy of history. The sources analyzed for this purpose are parts of the research developed in the thesis The Historical Formation (Bildung) as a Principle of the Didactics of History in High School: Theory and Praxis ${ }^{4}$ and, for this text, part of the published articles by professor Isabel Barca (University of Minho, Portugal) were inventoried between the years 2000 and 2012. The results were organized into two thematic categories: in the first theme it was possible to notice that among the most cited authors there are philosophers of logical inspiration (analytical and/or positivist) from Anglo-American critical philosophy in dialogue with authors from the educational sciences (regarding the proposal for conceptual change); in the second theme there are approaches that privileged the contribution of the philosopher and historian Jörn Rüsen regarding historical consciousness, even without abandoning some previous references and influences (characteristic of critical philosophy). The discussion based on the texts of historical education in Portugal may help the understanding of concepts such as competences, progression, and also, about approximations between History and Psychology regarding to substantive and second-order concepts. In addition, on how it is possible to perceive the influences of the theory and philosophy of history in the way empirical data are analyzed, such as explanations and/or narratives by students. It is hoped to have contributed elements that will provide historicity to the debates in the field of didactics of History thought in an intrinsic relation with the theory of history. What can contribute with teachers-researchers who seek references in the field of historical education in the Ibero-American scope, making it possible to perceive specific characteristics from each group, as well as their dialogues and contributions to the debates of the didactics of History.

Keywords: Historical education; Didactics of History; Historical consciousness.

\section{INTRODUÇÃO E METODOLOGIA}

Dando continuidade aos inventários apresentados em encontros anteriores da $\mathrm{ANPUH}^{5}$, passamos agora para outro grupo importante nesse campo de discussões: a Educação Histórica de Portugal representada pelos textos da professora Isabel Barca. Esse trabalho foi construído utilizando partes da tese de doutorado A Formação Histórica (Bildung) como Princípio da Didática da História no Ensino Médio: Teoria e Práxis, defendida em março de 2017, na Universidade Federal do Paraná, sob orientação da professora Maria Auxiliadora Moreira dos Santos Schmidt, coordenadora do Laboratório de Pesquisa em Educação Histórica (LAPEDUH/UFPR).

A pesquisa se dedicou a estabelecer um diálogo entre possibilidades de uma educação histórica perspectivada pela práxis que se contrapõe ao discurso do estabelecimento de habilidades e competências prévias. Parece existir um acompanhamento das discussões sobre competências, no Brasil e no mundo, que não foram pensadas no âmbito

\footnotetext{
${ }^{3}$ GRAMSCI, 1984.

${ }^{4}$ OLIVEIRA, 2017a.

${ }^{5}$ Em 2016 no encontro regional da ANPUH-PR em Curitiba apresentei uma discussão sobre o conceito de competências na didática da história alemã. Em 2017, no encontro nacional da ANPUH em Brasília a discussão apresentada foi sobre as influências teóricas da History Education a partir dos textos do professor Peter Lee. Os textos podem ser acessados nos links: <http://www.encontro2016.pr.anpuh.org/resources/anais/45/1467144854_ARQUIVO_TextocompletoANPUHPR2016.pdf>. [Consulta realizada em 14/03/2019]; e <https://www.snh2017.anpuh.org/resources/anais/54/1486468466_ARQUIVO_TextocompletoANPUH2017_ThiagoDivardim.pdf >. [Consulta realizada em $14 / 03 / 2019]$.
} 
da própria história e de seu ensino. Com a intenção de compreender de maneira mais aprofundada esses movimentos é que organizamos essa discussão.

Nas notas iniciais escritas por Antonio Gramsci, a respeito da concepção dialética da História, o autor alertou sobre a necessidade de criticar as próprias concepções de mundo. Propõe também que se realize a crítica das filosofias que nos deixaram estratificações.

O início da elaboração crítica é a consciência daquilo que somos realmente, isto é, um «conhece-te a ti mesmo» como produto do processo histórico até hoje desenvolvido, que deixou em ti uma infinidade de traços recebidos sem benefício no inventário. Deve-se fazer, inicialmente, este inventário ${ }^{6}$.

A fim de descobrirmos nossas limitações ou conformismos, na intenção de não utilizarmos conceitos ou mesmo criticá-los de maneira bizarra, é necessário fazer um inventário. Na tese citada trabalhei com todas as publicações da autora em português, mas, nesse caso, a discussão está limitada a uma revisão dos elementos da teoria e filosofia da História presentes em sua tese de doutoramento (1996) e alguns de seus artigos para respeitar o limite de páginas estabelecido nessa ocasião.

O artigo se propõe a realizar esse inventário a partir dos textos da professora doutora Isabel Barca com uma perspectiva principal: um levantamento das influências teóricas de sua produção e a interlocução com os conceitos de formação e de consciência histórica. O resultado dessas análises resultou na categorização em dois temas, «mudança conceptual e a filosofia crítica ${ }^{7}$ anglo-americana» e «textos com influências da teoria da consciência histórica». Antes de adentrar a análise dos textos cabe uma pequena apresentação da autora.

A professora Isabel Barca atua como associada com Agregação na Universidade do Minho. Possui doutorado em Ensino de História (History in Education) pela Universidade de Londres, mestrado em Ensino de Ciências Sociais pela Universidade de Boston e licenciatura em História pela Universidade do Porto. Desenvolve atividades de docência

\footnotetext{
${ }^{6}$ GRAMSCI, 1984: 12.

${ }^{7}$ Nesse artigo farei referência a vários autores do campo da filosofia e teoria da História. Esses autores se localizam em campos diferentes do que poderíamos chamar de problema clássico contemporâneo do historicismo. Podemos dividir os autores da filosofia da história em dois grupos: aqueles que discutiram a metafísica da história, e aqueles que discutiram a epistemologia da história. Ou ainda, conforme a divisão realizada por Patrick Gardiner no livro Teorias da História (1969), filosofia especulativa e filosofia crítica. Muitos dos autores que serão citados fazem parte do segundo grupo, porém esse campo subdivide-se: a epistemologia (ou filosofia crítica) da história foi discutida por filósofos de inspiração lógica (analítica e/ou positivista), e filósofos de inspiração hermenêutica. Para homogeneizar a forma de referência, falarei «filosofia crítica» na maior parte dos casos me referindo ao grupo de teóricos e filósofos da História citados pela professora Isabel Barca e pelo professor Peter Lee. Entre os citados com mais frequência estão: Robin George Collingwood; William Herbert Dray; Karl Popper; Carl Gustav Hempel; Arthur Coleman Danto; William Henry Walsh. Todas as referências a esses nomes estão realizadas a partir dos textos da professora Isabel Barca, apenas os textos delas onde as referências secundárias poderão ser encontradas é que constarão nas referências do presente artigo.
} 
e investigação no campo da cognição e da educação histórica, com diversos projetos e estudos nesse âmbito.

\section{MUDANÇA CONCEPTUAL E FILOSOFIA CRÍTICA}

Os debates da mudança conceptual ${ }^{8}$, muito utilizados nas áreas das ciências biológicas e mesmo na matemática, apontam que têm se baseado no pressuposto de que não se pode teorizar sobre modelos de aprendizagem se não houver uma reflexão sobre a ciência que se ensina. A partir disso os modelos de aprendizagem tendem a sair de uma concepção de aquisição de conceitos para a ideia de mudança conceitual em que a mudança passou a ser percebida como qualitativa.

Consideram decisivo que é aos alunos que cabe a construção (reconstrução) das novas ideias. Radicam numa perspectiva construtivista que advoga que o processo de aprender implica que quem aprende recorra aos seus esquemas (ou maneiras de aprender) para enfrentar uma situação que tenta compreender 9 .

É desses pressupostos que partiram as discussões relacionadas, por exemplo, a aula-oficina proposta pela pesquisadora Isabel $\mathrm{Barca}^{10}$. As necessidades de levar em consideração sempre os conhecimentos prévios dos alunos, para depois buscar a mudança conceptual com um papel ativo dos envolvidos em busca de uma progressão que parte do que é familiar para outro momento que demonstrará a aprendizagem influenciada pela ciência, e ainda, sem deixar de lado a epistemologia da própria história. É a isso que se refere à aprendizagem histórica situada (ou cognição histórica situada) no âmbito da educação histórica discutida pela professora Isabel Barca.

Em relação a esse primeiro tema a referência discutida foi justamente a que deu sustentação para uma série de publicações posteriores da pesquisadora, trata-se da tese de doutoramento defendida na Universidade de Londres no ano de 1996 e publicada em Portugal em 2000. A tese é intitulada O Pensamento Histórico dos Jovens: Ideias dos Adolescentes acerca da Provisoriedade da Explicação Histórica. Para realizar uma discussão a respeito do conceito «explicação histórica», que foi objeto de análise da autora em relação às explicações produzidas por estudantes, realizou uma revisão aprofundada das diferentes perspectivas da filosofia da História. Suas discussões pautaram-se em quatro modelos gerais: nomológico-dedutivo, racional, narrativo e estrutural. A autora apresentou qual uso do conceito de explicação que ela fez em seu estudo:

\footnotetext{
${ }^{8}$ SANTOS, 1998: 169-170.

${ }^{9}$ SANTOS, 1998: 173.

${ }^{10}$ BARCA, 2004.
} 
«o conceito de explicação histórica é usado no sentido de uma resposta temporária à pergunta sobre porque é que ocorreu um dado acontecimento ou situação passada» ${ }^{11}$.

Os representantes do pensamento nomológico-dedutivo são principalmente Hempel e Popper, o primeiro ligado aos modelos de leis gerais, e o segundo ligado provisoriedade das explicações fracas ou ainda não refutadas. Além desses autores, McClelland e Gardiner ampliaram um pouco a discussão defendendo a semelhança da História com as ciências sociais e salientando o que seriam especificidades das explicações históricas.

$\mathrm{Na}$ perspectiva do modelo racional a História forma um campo autônomo em relação a outras ciências. A inferência a partir de evidências seriam uma das características para a produção de uma explicação histórica completa. William Herbert Dray seria um dos principais representantes dessa perspectiva ao discutir que explicações sobre «como foi possível» devem responder questionamentos do tipo "por quê» para se obter uma explicação logicamente satisfatória. Autores como Walsh, Gallie e Atkinson, de acordo com a autora Isabel Barca, seguem basicamente o modelo racional.

É nesse ínterim que se encaixam os filósofos defensores da explicação histórica como uma narrativa autoexplicativa. Walsh, por exemplo, deu contribuições em uma discussão paralela com a Física a respeito do conceito de «coligação» (coligatory) para evitar a rejeição colingwoodiana a respeito da generalização nas explicações em História.

$\mathrm{Na}$ perspectiva do modelo chamado de estrutural as estruturas e conjunturas condicionantes de ações e acontecimentos imediatos são objeto da discussão na História. Esse campo envolveria desde o modelo estruturalista (representado por autores como Thompson e Hobsbawm, como marxistas que admitem um papel ativos dos sujeitos), ou até autores como Christopher Lloyd, como representante estruturista/estruturismo, que defende que a causalidade ontológica e complexa deve ser explicada por raciocínios também complexos, levando em consideração deduções, induções, analogias, modelos e metáforas. Deve-se levar em consideração uma relação entre indivíduo e imediato, mas sem esquecer de elementos como curta e longa duração ${ }^{12}$.

A partir dessa revisão, a autora propôs um modelo básico de explicação resultante da discussão.

A explicação histórica é entendida como uma resposta a uma pergunta de tipo "porquê?» sobre acções, acontecimentos e situações do passado humano. Ela pode incluir perguntas do tipo "como foi possível?». Cada explicação pressupõe uma selecção de factores razões, motivos, disposições, condições externas, estruturais, conjunturais, segundo as linhas de diferentes modelos explicativos. Cada autor pode

\footnotetext{
${ }^{11}$ BARCA, 2000: 43.

${ }^{12}$ BARCA, 2000: 43-61.
} 
atribuir uma importância relativa diferente aos factores seleccionados e, entre uma gama de factores (condições existentes), uns podem ser considerados condições necessárias, outros condições contributivas facilitadoras do explanandum. As condições que estabelecem a diferença quanto a uma situação ter ocorrido, ou não, podem ser consideradas a causa ${ }^{13}$.

Vale reforçar que a autora ainda realizou discussões específicas sobre a provisoriedade das explicações em História com base em outros autores, tais como McCullagh, ou ainda autores do campo do pós-modernismo (de acordo com a autora, Foucault e Derrida). O ponto que mais interessa nesse inventário está relacionado a análise dos dados de pesquisa. Nesse caso, a categorização ocorreu de acordo com os cinco níveis de progressão (1. A estória, 2. A explicação correcta, 3. Quanto mais factores melhor, 4. Uma explicação consensual?, 5. Perspectiva). Essas categorias foram influenciadas pelos debates da teoria da História e se relacionam ao modelo da mudança conceptual como contribuição das ciências da educação, segundo as ideias de Barca.

As perguntas principais que nortearam a pesquisa de $\mathrm{Barca}^{14}$ foram: «Que ideias possuem os alunos a respeito da provisoriedade da explicação histórica? E, que critérios operam na escolha de explicações históricas?» Na trajetória que percorreu para responder a essa questão, são apresentadas as referências que nortearam o debate acadêmico na área da História e do ensino durante a segunda metade do século XX e quais foram os avanços trazidos pelos referenciais da Educação Histórica para as discussões a respeito da atividade de ensinar e aprender história. Nesse sentido a autora destaca que o marco referencial para os avanços das discussões, especificamente aquelas que não se limitaram, ainda que estabelecendo diálogos com os referenciais piagetianos dos estágios de desenvolvimento psicológico, foram pesquisas de Peter Lee, publicadas a partir de 1978.

Avançando para um texto muito conhecido no Brasil, é possível perceber como a autora propôs, com base nesses referenciais, um modelo metodológico para aulas de história, trata-se da aula-oficina ${ }^{15}$. De acordo com Barca, para acompanhar a progressão do pensamento dos alunos é necessário levar em consideração as ideias tácitas para que se acompanhe a mudança conceptual. Não obstante, a preocupação deve se centrar nas instrumentalizações e não na unidade temática. E a forma de acompanhamento se dá pelas explicações anteriores e posteriores produzidas pelos estudantes ${ }^{16}$.

No texto das Terceiras Jornadas Internacionais de Educação Histórica a autora sintetiza algum dos olhares dos historiadores sobre o conhecimento histórico. Dessa vez

\footnotetext{
${ }^{13}$ BARCA, 2000: 61, 152.

${ }^{14}$ BARCA, 2000.

${ }^{15}$ BARCA, 2004.

${ }^{16}$ BARCA, 2004: 137.
} 
inseriu Danto ${ }^{17}$ juntamente com Walsh ${ }^{18}$ e Dray ${ }^{19}$ como adeptos da discussão sobre perspectiva na historiografia, e o historiador como sujeito inserido em uma cosmovisão ${ }^{20}$. Ressalta que o ponto de vista não significa subjetivismo acrítico, mas é visto como fator fundante da própria ciência da história.

Foi possível perceber na análise do conteúdo desse primeiro grupo de textos que, apesar de um debate com outras formas de pensar a produção do conhecimento histórico, se fez presente na maioria das produções um posicionamento relacionado à filosofia crítica da História representada sobretudo por Walsh, Dray, Popper, e por Collingwood. $\mathrm{E}$, a discussão entre esses referenciais vai à contramão das versões únicas da História e na importância do ponto de vista, ou perspectiva, como característica própria da cientificidade da História. Elementos que nas atividades de ensino e aprendizagem da História poderiam ser verificados na progressão das explicações dos estudantes quando comparadas as ideias tácitas às explicações posteriores a apresentação dos elementos científicos. O que a autora discute como progressão do pensamento, mudança nas explicações e em alguns momentos da sua produção a aquisição de competências do pensamento histórico.

\section{TEXTOS COM INFLUÊNCIAS DA TEORIA DA CONSCIÊNCIA HISTÓRICA}

Toda atividade de tornar o passado presente ocorre através de uma atividade intelectual compreendida como narrativa ${ }^{21}$. Pode-se dizer que o autor aponta que a narrativa é como dos feitos surge a história «[...] Ao tornar-se presente, o passado adquire o estatuto de História» ${ }^{22}$. O autor ainda aponta a necessidade de compreender a categoria sentido:

Sentido articula percepção, interpretação, orientação e motivação, de maneira que a relação do homem consigo e com o mundo possa ser pensada e realizada na perspectiva do tempo. Sentido histórico na relação com o mundo significa uma representação da evolução temporal do mundo humano, tanto baseada na experiência quanto orientadora e motivadora do agir. Também na relação do homem com si mesmo, o tempo é interpretado em consecução, de modo que seja alcançado um mínimo de consistência do «eu»: a identidade histórica ${ }^{23}$.

As narrativas são históricas quando possuem sentido na comunicação da vida prática quando compõem uma relação na qual o passado é interpretado a luz do presente,

\footnotetext{
${ }^{17}$ DANTO, 1965.

${ }^{18}$ WALSH, 1967.

${ }^{19}$ DRAY, 1980; DRAY, 1991.

${ }^{20}$ BARCA, 2006a: 18.

${ }^{21}$ RÜSEN, 2001: 149.

${ }^{22}$ RÜSEN, 2001: 154.

${ }^{23}$ RÜSEN, 2001: 156.
} 
que é entendido e relacionado com o futuro, este é esperado de acordo com a interpretação. Esses elementos relacionam a narrativa ao fenômeno da consciência histórica ${ }^{24}$.

É possível perceber que, a partir de 2004, mas sobretudo a partir de 2006, a pesquisadora Isabel Barca amplia as referências a teoria da consciência histórica, sem, no entanto, abandonar os referenciais que já utilizava. Para demonstrar esse processo de aproximação com a teoria destacarei dois textos: um que reflete estágios intermediários de utilização dessa teoria e outro que deixa de categorizar ideias em progressão e realiza a análise das narrativas de estudantes como expressão da consciência histórica.

Em 2011, o texto O papel da educação histórica no desenvolvimento social se propõe na introdução a traçar um histórico das pesquisas em educação histórica, e demonstra que as teorias em torno do quadro epistemológico de Jörn Rüsen foram mais recentes em comparação às pesquisas inovadoras da segunda metade do século XX na Inglaterra ${ }^{25}$.

conduzidos numa lógica de perceber padrões explicativos dos jovens numa perspectiva de maior ou menor grau de elaboração histórica (modelo de progressão conceptual) revelam uma diversidade de níveis que vão desde ideias incoerentes, fragmentadas, ou coerentes mas centradas na descrição da estória, até um nível explicativo - por vezes restrito, se focalizando em um ou dois factores ou apresentando como simples listagem, outras vezes mais elaborado, quando é visível uma narrativa coerente, descritiva-explicativa ${ }^{26}$.

Ao tratar do quadro de pesquisas que se desenvolveram tomando como referência à contribuição rüseniana, Barca apontou o desenvolvimento do projeto Consciência Histórica - Teorias e Práticas, e destacou como contribuição «fundamental e fundacional do "Grupo Araucária" ${ }^{27}$ para uma visão pelo prisma da Educação Histórica no Brasil $»^{28}$. Outra influência destacada foi o projeto Youth and History ${ }^{29}$. O trecho abaixo define bem a amplitude e importância do projeto:

\footnotetext{
${ }^{24}$ RÜSEN, 2001.

${ }^{25}$ BARCA, 2011: 27.

${ }^{26}$ BARCA, 2011: 28.

${ }^{27}$ O Grupo Araucária foi formado por professores de História do Município homônimo. Os professores desse município na década de 1990 conquistaram por meio da militância sindical um plano de carreira, o direito a hora-atividade concentrada e a formação continuada assessorada pela Universidade Federal do Paraná. No caso dos professores de História esse processo de formação resultou em uma relação com o LAPEDUH. Sobre a trajetória do Grupo Araucária conferir minha dissertação de mestrado (OLIVEIRA, 2012) ou o texto A educação histórica e as mudanças de paradigma na cultura escolar no município de Araucária (THEOBALD, 2005. Artigo apresentado em evento).

${ }^{28}$ BARCA, 2011: 32.

${ }^{29}$ ANGVIK \& BORRIES, eds., 1997.
} 
O projeto "Youth and History», desenvolvido nos países europeus a partir de 1994, com base na rede European Standing Conference of History Teachers Associations procurou dar respostas às questões sobre a qualidade, as características e os resultados do ensino de História, bem como sobre a configuração geral da consciência histórica dos jovens europeus. Isso foi feito a partir de um levantamento comparativo de amplo alcance, através de um questionário respondido por jovens de 15 anos de 25 países europeus mais Israel e Palestina e seus professores de História, versando sobre conteúdos, métodos e concepções de História e cidadania, com sustentação no conceito de consciência histórica. O levantamento europeu conseguiu 31.000 respondentes. A pesquisa constituiu-se da elaboração, aplicação e tabulação de um questionário para alunos e outro para professores, definido após várias reuniões entre as dezenas de pesquisadores de toda a Europa, liderados por Magne Angvik e Bodo von Borries $^{30}$.

As discussões revisadas por Barca demonstram alguns encaminhamentos das pesquisas no campo da educação histórica e o tipo de análise realizada com os dados levantados. Foi possível notar que, majoritariamente, os dados levantados nas pesquisas foram analisados de acordo com modelo de elaboração ou mudança conceptual. Além desse modelo, as categorizações são marcadas predominantemente por estudos descritivos, pela análise qualitativa referenciada na Grounded Theory ${ }^{31}$.

No texto Ideias chave para a educação histórica: uma busca de (inter)identidades ${ }^{32}$, há um subtítulo sobre "A narrativa como face da consciência histórica», em que a autora apresenta o seguinte:

$\mathrm{Na}$ vertente da pesquisa em ideias de segunda ordem ${ }^{33}$, à preocupação central de compreender como as crianças e jovens constroem as suas ideias sobre evidência, explicação multiperspectivada, significância ou mudança em História, juntou-se na década de 1990 a de se promover a consciência histórica dos jovens, uma ideia que parte do pressuposto de que há uma necessidade de orientação temporal intrínseca nos seres humanos e que se fundamenta em reflexões filosóficas de Jörn Rüsen

\footnotetext{
${ }^{30}$ CERRI \& AMÉZOLA, 2007.

${ }^{31}$ STRAUSS \& CORBIN, 1991 apud BARCA, 2011: 34.

${ }^{32}$ BARCA, 2012a.

${ }^{33}$ A divisão entre conceitos substantivos e de segunda ordem foi uma proposta do grupo inglês da History Education de acordo com Isabel Barca (2011). A proposta tem influência da psicologia cognitiva e aponta Donaldson (1978) como a melhor contribuição da psicologia cognitiva para a discussão referente à progressão no pensamento das crianças (BARCA, 2000: 27, nota 4). De acordo com a autora: «Os conceitos “de segunda ordem”, também designados conceitos estruturais ou meta-históricos, exprimem noções ligadas a natureza do conhecimento histórico, tais como compreensão empática, explicação, evidência, significância, mudança em História. Os conceitos “substantivos" referem-se a noções ligadas aos conteúdos históricos, como monarquia, democracia, feudalismo, revolução industrial, Renascimento, descobrimentos» (BARCA, 2011: 25).
} 
(1993, 2001, 2004, 2007; SCHMIDT, BARCA \& MARTINS, 2010). Aprofundando a compreensão histórica em torno da inter-relação de diversos segmentos temporais, os seres humanos veem-se como parte de um contexto humano muito maior do que as suas próprias vidas e adquirem ferramentas conceptuais para (melhor?) se orientarem e se constituírem como agentes do seu próprio tempo ${ }^{34}$.

Nota-se uma diferença entre a produção da «aula-oficina» e as possibilidades abertas a partir da inserção do conceito de consciência histórica no debate. A discussão nesse trecho envolve a análise de narrativas de alunos de Portugal e do Brasil, referentes a um estudo qualitativo que envolveu pesquisadores de quatro países (Brasil, Cabo Verde, Moçambique e Portugal).

Nesse sentido, há uma diferença fundamental entre a categorização de narrativas de alunos em relação aos textos citados anteriormente. Se, por exemplo, nos textos do primeiro tema a categorização fora realizada de maneira a demonstrar a possibilidade da progressão das ideias, no texto de 2012 as análises das narrativas dizem mais respeito à identidade e identificação dos alunos no presente em relação ao passado do que uma hierarquização da qualidade progressiva das ideias históricas. Ou seja, as análises das narrativas se aproximam mais do conceito rüseniano do que da ideia de narrativa mais adequada pensada na filosofia crítica da História, a exemplo de Hempel ou Danto.

Apesar disso, os encaminhamentos finais desse mesmo texto (2012) apontam um retorno aos referenciais apresentados anteriormente relacionados à aula-oficina, tanto como metodologia quanto na análise e categorização das ideias dos estudantes:

1. Recolha inicial de dados sobre as ideias prévias dos alunos acerca de um conceito substantivo, seleccionado dentro de uma determinada unidade em estudo,

2. Análise das ideias prévias dos alunos segundo um modelo (simplificado) de progressão conceptual: categorização das ideias de alunos desde ideias incoerentes e alternativas até às relativamente válidas;

3. Desenho, planeamento e implementação de uma unidade temática tendo em conta um refinamento progressivo das ideias históricas dos alunos previamente diagnosticadas;

4. Recolha de dados sobre as ideias dos alunos a posteriori, aplicando o mesmo instrumento do momento inicial;

5. Aplicação de um instrumento de metacognição aos alunos para monitorizar o processo de ensino e aprendizagem ${ }^{35}$.

\footnotetext{
${ }^{34}$ BARCA, 2012a: 40.

${ }^{35}$ BARCA, 2012a: 46-47.
} 
Ao observar a citação, torna-se possível apontar algumas questões relacionadas à própria teoria da consciência histórica citada anteriormente no texto da autora, o que possibilita buscar perceber relações possíveis entre a ideia de formação intrínseca da proposta da autora, e, além disso, as possibilidades de dar continuidade a esse debate. Uma vez que a tentativa é de incorporação do conceito de consciência histórica, poderíamos pensar que o recolhimento proposto no primeiro item acaba realizando um corte significativo das possibilidades de trabalhos com a História que estaria relacionada às demandas das consciências históricas (e a relação disso com a Cultura Histórica) associadas às necessidades formativas do presente e dos horizontes de expectativa relacionados às questões de orientação e motivação da consciência histórica, de acordo com a teoria de Rüsen ${ }^{36}$.

O segundo ponto mantém a progressão das ideias, mesmo sendo análise de ideias prévias. Ainda que esses pontos sejam apenas indicativos de um trabalho, que na realidade escolar envolve relações complexas, a consideração de ideia prévia ligada a um conteúdo de uma unidade temática, por exemplo, não corresponde a expressão da consciência que, como algo inerente a vida humana em sociedade, poderia explicitar questões que vão além de um conteúdo previamente definido.

Os outros pontos (3 ao 5) aproximam-se mais das questões relativas à ideia da narrativa histórica na contribuição rüseniana, no entanto, ainda não contemplam a dimensão da orientação e motivação da consciência, talvez, pela definição antecipada de um conteúdo e da aproximação das ideias dos alunos em caráter progressivo entre o momento anterior da aula e o momento posterior.

A exploração e análise de ideias prévias dos alunos e do consequente processo de conceptualização em aula situa-se num ambiente de aula construtivista, que em Portugal se convencionou designar «aula oficina» (BARCA, 2004) $)^{37}$.

Já em Rüsen, a narrativa é discutida como a própria expressão da consciência histórica, uma vez que toda forma de pensar historicamente se efetiva mediante a narrativa.

O pensamento histórico, em todas as suas formas e versões, está condicionado por um determinado procedimento mental de o homem interpretar a si mesmo e a seu mundo: a narrativa de uma história. Narrar é uma prática cultural de interpretação do tempo, antropologicamente universal. A plenitude do passado cujo tornar-se presente se deve a uma atividade intelectual a que chamamos de "história» como

\footnotetext{
${ }^{36}$ RÜSEN, 2014.

${ }^{37}$ BARCA, 2012a.
} 
passado tornado presente assume, por princípio, a forma de uma narrativa. O pensamento histórico obedece, pois, igualmente por princípio, à lógica da narrativa ${ }^{38}$.

O último texto da professora Isabel Barca analisado neste inventário foi $A$ formação da consciência social dos jovens no horizonte da educação histórica. Como o próprio título evidencia, há uma preocupação aparente entre a formação histórica e a relação com a sociedade. $\mathrm{O}$ artigo discute resultados de um estudo qualitativo de análise das narrativas históricas nacionais e mundiais desenvolvidas por jovens portugueses, moçambicanos e brasileiros. E, apresenta alguns resultados das análises qualitativas citados no resumo da seguinte forma:

A análise indutiva das narrativas sugeriu que os jovens destes países revelam uma identidade nacional relativamente fundamentada, sem xenofobias. Quanto às narrativas globais, as dos jovens portugueses e moçambicanos aparecem muito menos substanciadas do que as nacionais, enquanto as dos jovens brasileiros narram a um mesmo nível a história do país e do mundo, interligando-as. As produções portuguesas e brasileiras mostram poucos protagonistas, emergindo apenas alguns «vilões». Por outro lado, os jovens brasileiros e moçambicanos mostram-se interventivos face ao presente; já os jovens portugueses, que apareciam como meros espectadores da História, só recentemente parecem estar a mudar de atitude. Estes e outros resultados da análise das narrativas dos jovens podem constituir-se como pistas valiosas para o trabalho docente, na perspectiva de intervenção positiva na formação da consciência histórica e social dos jovens ${ }^{39}$.

É possível perceber que o tipo de análise se difere de uma linearidade progressiva de explicações históricas como era mais comum nos textos agrupados em torno da mudança conceitual e da filosofia crítica. Antes o método de análise privilegiava o encaixe em linhas progressivas de explicações menos elaboradas para explicações mais elaboradas. Geralmente, a aparência da análise não envolvia relações temporais de orientação, ou de atribuição de sentido ao passado no presente. Nesse caso, a própria referência à ideia de consciência social dá indícios de preocupações mais interessantes com a realidade na qual o sujeito que narra está inserido.

Um exemplo disso é a preocupação da autora com o fato de que os alunos que se referem a sujeitos históricos o fazem mais para citar «vilões» do que para estabelecer identidade ou identificação com sujeitos da história. Ao passo que outros se mostram mais «interventivos» no presente. Entre os autores citados nessa publicação não

\footnotetext{
${ }^{38}$ RÜSEN, 2001: 149.

${ }^{39}$ BARCA, 2011: 437.
} 
aparecem mais os filósofos de inspiração lógica (analítica e ou positivista) da filosofia crítica, e foi privilegiada a contribuição rüseniana. Embora a maior parte das citações de trabalhos da área da educação histórica sejam aqueles mais ligados a History Education (Rosalyn Ashby; Peter Lee; Peter Seixas; Keith Barton — autores ingleses, estadunidense e canadense) e, portanto, influenciados por esse campo da teoria e filosofia da História.

A tabela abaixo apresenta parte dos resultados do inventário de acordo com a tese citada $^{40}$. Ao contrário do presente texto, a tabela apresenta referenciais citados em todos os 19 textos analisados na tese, e os nomes em negrito são os que aparecem com maior incidência em relação à teoria e filosofia da História.

Tabela 1. Resultado do inventário com os autores mais citados

\begin{tabular}{|c|c|c|c|c|}
\hline $\begin{array}{c}\text { Autor } \\
\text { analisado }\end{array}$ & $\begin{array}{c}\text { Referências da } \\
\text { filosofia/teoria da } \\
\text { História }\end{array}$ & $\begin{array}{c}\text { Referências } \\
\text { da } \\
\text { Psicologia }\end{array}$ & $\begin{array}{l}\text { Referências da Educação } \\
\text { Histórica/didática da História }\end{array}$ & Outras áreas \\
\hline $\begin{array}{l}\text { Isabel Barca } \\
\text { (tema 1) }\end{array}$ & $\begin{array}{l}\text { Robin George } \\
\text { Collingwood; William } \\
\text { Herbert Dray; Karl } \\
\text { Popper; C. B. McCullagh; } \\
\text { Michel Foucault; Carl } \\
\text { Gustav Hempel; (Fay, } \\
\text { Pomper e Vann, 1998); } \\
\text { Jörn Rüsen; Arthur } \\
\text { Coleman Danto; } \\
\text { William Henry Walsh; } \\
\text { Jacques Le Goff; Pierre } \\
\text { Nora; Ignacio Olábarri }\end{array}$ & $\begin{array}{l}\text { J. Bruner; } \\
\text { M. } \\
\text { Donaldson; } \\
\text { Lev } \\
\text { Semenovitch } \\
\text { Vygotsky }\end{array}$ & $\begin{array}{l}\text { Rosalyn Ashby; Peter Lee; } \\
\text { Denis J. Shemilt }\end{array}$ & $\begin{array}{l}\text { Maria Eduarda } \\
\text { Vaz Moniz } \\
\text { dos Santos } \\
\text { (Mudança } \\
\text { Conceptual } \\
\text { na Sala de } \\
\text { Aula); Bliss, } \\
\text { Monk Ogborn, } \\
\text { 1983 (análise } \\
\text { qualitativa) }\end{array}$ \\
\hline $\begin{array}{l}\text { Isabel Barca } \\
\text { (tema 2) }\end{array}$ & $\begin{array}{l}\text { Jörn Rüsen; } \\
\text { Michael Oakeshott; } \\
\text { Christopher Lloyd; } \\
\text { Reinhart Koselleck; } \\
\text { Fulbrook (2002); H. } \\
\text { White; Jenkins (1991); } \\
\text { Hegel; Spengler }\end{array}$ & $\begin{array}{l}\text { R. Arends; } \\
\text { Vygotsky }\end{array}$ & $\begin{array}{l}\text { Peter Lee; Peter Seixas; Magne } \\
\text { Angvik and Bodo von Borries; } \\
\text { Maria Auxiliadora Schmidt; Seixas } \\
\text { \& Clark (2004); Hilary Cooper; } \\
\text { Letourneau \& Moisan (2004), no } \\
\text { Canadá; Wertsch (2004), na Rússia; } \\
\text { Barton \& McCully (2005) na Irlanda } \\
\text { do Norte; Waldron \& Pike (2005) } \\
\text { na República da Irlanda; Kokkinos } \\
\text { \& Nakou, 2004; Magalhães; Isabel } \\
\text { Barca; Marília Gago; Gallie; Arthur } \\
\text { Chapman; Rafael Saddi; Alamir } \\
\text { Compagnoni; Rosi Gevaerd; } \\
\text { Marcelo Fronza; Ronaldo Cardoso; } \\
\text { Marlene Cainelli; Lindamir Zeglin } \\
\text { Fernandes; Schmidt \& Garcia; } \\
\text { Estevão C. de Rezende Martins; } \\
\text { Saddi \& Silva; Cainelli \& Lourençato }\end{array}$ & $\begin{array}{l}\text { Donovan \& } \\
\text { Bransford, } \\
\text { 2005; Pais; } \\
\text { Hargreaves; } \\
\text { Nóvoa; } \\
\text { Fenstermacher; } \\
\text { Mitchell; Lesne; } \\
\text { Fosnot; Strauss } \\
\text { e Corbin }\end{array}$ \\
\hline
\end{tabular}

Fonte: OLIVEIRA, 2017a: 336

${ }^{40}$ OLIVEIRA, 2017a: 336. 
Por esses elementos é possível apontar essa prevalência em um primeiro momento das teorias e filosofias identificadas como críticas (característica da segunda metade do século XX no contexto anglo-americano), e uma adesão aos referenciais da consciência histórica (mais frequentes nas produções da teoria da História e didática da História alemã) na segunda etapa.

\section{CONSIDERAÇÕES}

Além da influência da filosofia crítica da História, o diálogo que a presente discussão propôs estabelecer de acordo com a metodologia do inventário ${ }^{41}$ tornou possível identificar camadas que compõem a discussão da Educação Histórica em Portugal. Foi na relação com os diferentes campos de discussão da Educação Histórica (Inglaterra, outros autores de Portugal, no diálogo com o grupo brasileiro e as influências da didática da História alemã em todos os grupos citados) que historicamente se constituiu aquilo que hoje buscamos inventariar como campo da Educação Histórica. Mais do que a análise ou a crítica das diferentes concepções, o inventário buscou constituir uma espécie de «conhece-te a ti mesmo» da Educação Histórica a exemplo da proposta gramsciana.

Dessa forma espera-se ter contribuído com os debates da teoria da História, mais especificamente em relação às preocupações da Didática da História pensadas no âmbito da teoria e da pesquisa sobre as relações de ensino e aprendizagem histórica. Com esse terceiro texto submetido aos encontros da ANPUH é possível apontar que foi apresentado um inventário a partir da teoria com um olhar sobre diferentes perspectivas. Um olhar que partiu das discussões efetivadas coletivamente no âmbito do LAPEDUH e que tentou compreender um pouco das influências sobre o próprio grupo, assim como sobre o campo da Educação Histórica, a partir de suas diferentes perspectivas: Educação Histórica, de Portugal; History Education, da Inglaterra; e Didática da História, com referência em autores alemães.

Fica aberta a possibilidade de continuidade dessas pesquisas e inventariar produções brasileiras relacionadas aos debates que envolvem preocupações com o ensino e a aprendizagem da História e suas relações com a teoria da História. O que poderá contribuir para o conhecimento mais aprofundado dos debates da área, assim como possíveis desdobramentos em relação a métodos, estratégias e contribuições à didática da História.

\footnotetext{
${ }^{41}$ GRAMSCI, 1984.
} 


\section{BIBLIOGRAFIA}

ANGVIK, Magne; BORRIES, Bodo von, eds. (1997) - Youth and History - A comparative European Survey on Historical Consciousness and Political Attitudes Among Adolescents. Hamburg: Edition Körber-Stiftung.

BARCA, Isabel (2000) - O Pensamento Histórico dos Jovens: Ideias dos Adolescentes acerca da Provisoriedade da Explicação Histórica. Braga: CEEP/Universidade do Minho.

(2004) - Aula Oficina: do Projecto à Avaliação. In BARCA, Isabel, org. - Para uma Educação Histórica com Qualidade: Actas das IV Jornadas Internacionais de Educação Histórica. Braga: CIEd/Universidade do Minho; Instituto de Educação e Psicologia/Universidade do Minho, p. 131-144.

(2006a) - Em torno da Epistemologia da História. In BARCA, Isabel; GAGO, Marília, org. — Questões de Epistemologia e Investigação em Ensino da História: Actas das 3. ${ }^{a s}$ Jornadas Internacionais de Educação Histórica. Braga: CIEd/Universidade do Minho, p. 17-25.

(2006b) - Literacia e consciência histórica. «Educar em Revista». Dossiê Especial: Educação Histórica, vol. 22. Curitiba: UFPR, p. 93-112.

(2011) - O Papel da Educação Histórica no Desenvolvimento Social. In CAINELLI, Marlene; SCHMIDT, Maria Auxiliadora, org. - Educação histórica: teoria e pesquisa. Ijuí: Ed. Unijuí, p. 21-48. (2012a) - Ideias chave para a educação histórica: uma busca de (inter)identidades. "Revista de História», vol. 17, n. ${ }^{\circ} 1$ (jan./jun.), p. 37-51.

(2012b) - A formação da consciência social dos jovens no horizonte da educação histórica. «Educação», vol. 37, n. ${ }^{\circ} 3$ (set./dez.), p. 437-452.

CERRI, Luis Fernando; AMÉZOLA, Gonçalo (2007) - Jovens diante da história: ensino, aprendizagem e consciência histórica de jovens no Brasil e na Argentina. São Leopoldo: Unisinos.

DANTO, Arthur C. (1965) - Analytical philosophy of history. Cambridge: Cambridge University Press.

DRAY, William (1980) - Perspectives on history. Londres: Routledge and Kegan Paul.

(1991) - Comment. In VAN DER DUSSEN, W. J.; RUBINOFF, Lionel, eds. - Objectivity, method and point of view: Essays in the philosophy of history. Leiden: E. J. Brill, p. 170-190.

GRAMSCI, Antonio (1984) - Concepção dialética da história. 6. ${ }^{a}$ ed. Rio de Janeiro: Civilização Brasileira, p. 9-89. Parte I - Introdução ao estudo da Filosofia e do Materialismo Histórico.

MORAES, Maria Célia Marcondes de (2009) - "A Teoria Tem Consequências": Indagações sobre o Conhecimento no Campo da Educação. «Educação \& Sociedade», vol. 30, n.o 107 (maio/ago.), p. 585-607.

OLIVEIRA, Thiago Augusto Divardim de; SCHMIDT, Maria Auxiliadora (2016) - Um Inventário a partir da Teoria da História sobre Competências na Didática da História Alemã. In XV Encontro Regional de História (ANPUH). Curitiba: Anais do XV Encontro Regional de História, vol. I.

OLIVEIRA, Thiago Augusto Divardim de (2012) - A Relação Ensino e Aprendizagem como Práxis: A Educação Histórica e a Formação de Professores. Curitiba: Universidade Federal do Paraná. Dissertação de mestrado.

(2017a) - A Formação Histórica (Bildung) como Princípio da Didática da História no Ensino Médio: Teoria e Práxis. Curitiba: Universidade Federal do Paraná. Tese de doutorado.

(2017b) - Para conhecer a educação histórica: um inventário da History Education. In XXIX Simpósio Nacional de História - Contra os preconceitos: História e Democracia. Brasília: Anais do XXIX Simpósio Nacional de História - Contra os preconceitos: História e Democracia.

RÜSEN, Jörn (1987) - Reflexão sobre os fundamentos e mudança de paradigma na ciência histórica alemã-ocidental. In NEVES, Abílio Afonso Baeta; GERTZ, René E., orgs. - A nova historiografia alemã. Porto Alegre: Ed. da Universidade; UFRGS; Instituto Goethe; Instituto Cultural Brasileiro-Alemão. (2001) - Razão histórica. Teoria da história: Os fundamentos da ciência histórica. Trad. Estevão de Rezende Martins. Brasília: Ed. UnB. 
(2007) - História Viva: Formas e funções do conhecimento histórico. Trad. Estevão de Rezende Martins. Brasília: Ed. UNB.

(2007) - Reconstrução do Passado: Os princípios da pesquisa histórica. Trad. Asta-Rose Alcaide. Brasília: Ed. UNB.

(2014) - Cultura faz sentido. Orientações entre o hoje e o amanhã. Petrópolis: Vozes.

(2015) - Teoria da História: Uma teoria da história como ciência. Trad. Estevão de Rezende Martins. Brasília: Ed. UFPR.

SANTOS, Maria Eduarda Vaz Moniz dos (1998) - Mudança Conceptual na Sala de Aula - Um Desafio Pedagógico Epistemologicamente fundamentado. 2. ${ }^{a}$ edição. Lisboa: Livros Horizonte. (Biblioteca do Educador).

SCHMIDT, Maria Auxiliadora (2012) - Laboratório de Pesquisa em Educação Histórica: Uma Experiência de Investigação Colaborativa. «Revista de Educação Histórica», n. ${ }^{\circ} 1$ (jul.-nov.). Curitiba: REDUH-LAPEDUH-UFPR.

THEOBALD, Henrique Rodolfo (2005) - A educação histórica e as mudanças de paradigma na cultura escolar no município de Araucária. In SIMPÓSIO NACIONAL DE HISTÓRIA, 2005, LONDRINA Anais do XXIII Simpósio Nacional de História - História: guerra e paz. Londrina: ANPUH.

WALSH, W. H. (1967) - An introduction to philosophy of History. Londres: Hutchinson. 


\title{
A AULA-OFICINA E SUAS POSSIBILIDADES: VINTE ANOS DEPOIS, 1999-2019
}

\author{
MARIA DA CONCEIÇÃO SILVA* \\ BRENO MENDES** \\ CRISTIANO NICOLINI***
}

Resumo: O presente artigo analisa a proposta de aula-oficina elaborada pela pesquisadora portuguesa Isabel Barca, a qual sugeriu uma metodologia e epistemologia específicas do pensamento histórico no campo da Educação Histórica. A proposta visa compreender o pensamento dos jovens acerca da História e a forma em que se processa a aprendizagem da História ensinada a esses jovens escolares. Alguns desafios foram postos a professores e alunos desde a seleção de conteúdos e fontes para instigar e propor inferências e comparações, incentivando e motivando os estudos da História, propondo ainda o diálogo entre universidade e escolas de educação básica. Após vinte anos de realização dessa metodologia de aula-oficina em países entre os quais se destaca o Brasil, vários trabalhos vêm sendo realizados a exemplo da Universidade Estadual de Londrina, Paraná. Analisamos a relevância da proposta aula-oficina na atualidade, considerando os jovens como nativos digitais na sala de aula. Propomos a releitura de aula-oficina à luz da História Digital e o significado da webquest para o ensino da História para despertar o interesse pelos estudos e pela pesquisa da História, sobretudo no campo da Educação Histórica.

Palavras-chave: Aula-oficina; Educação histórica; Nativos digitais; História digital.

Abstract: This article analyzes the workshop-class proposal prepared by Portuguese researcher Isabel Barca, which suggested a specific methodology and epistemology of historical thinking in the field of Historical Education. This methodological proposal aims to understand the historical thinking of young people, as well as the learning of history taught in classes by teachers. Some challenges were posed to teachers and students from the selection of contents and sources to instigate and propose inferences and comparisons, encouraging and motivating the studies of History, and also proposing the dialogue between university and elementary schools. After twenty years of this workshop-class methodology in countries such as Brazil, several works have been carried out, such as the Universidade Estadual de Londrina, Paraná. We analyze the relevance of the proposed class-workshop in time present (today), considering young people as digital natives in the classroom. We propose the rereading of the workshop class in the light of Digital History and the meaning of the webquest for the teaching of History to arouse interest in history studies and research, especially in the field of Historical Education.

Keywords: Workshop-class; Historical education; Digital natives; Digital History.

\footnotetext{
* Faculdade de História - UFG/Brasil. E-mail: mariacsgo@gmail.com.

${ }^{* *}$ Faculdade de História - UFG/Brasil. E-mail: mendes.breno@gmail.com.

${ }^{\star * \star}$ Faculdade de História - UFG/Brasil. E-mail: cristiano.jan78@gmail.com.
} 
Até a década de 1980, os modelos de ensino predominantes no sistema escolar ocidental foram o tradicional e o não-diretivo. No caso específico das aulas de História, o primeiro tipo caracteriza-se predominantemente pela aula-conferência e pouco mudou desde aquele contexto até a atualidade. O professor assume o papel de detentor do conhecimento, enquanto os alunos se ocupam em ouvir, anotar, ler e memorizar informações que mais tarde serão cobradas em avaliações convencionais. Já no segundo modelo, a aula característica ocorre em forma de colóquio, oportunizando problematizações do saber histórico, porém mantendo a estrutura de uma aula tradicional, em que o professor ainda ocupa o centro do processo de ensino e aprendizagem ${ }^{1}$.

Nesse contexto, a Educação Histórica, campo no qual vinham se desenvolvendo investigações desde a década de 1970, passou a influenciar de forma mais significativa propostas de reestruturação do ensino de História nas escolas de países como a Inglaterra, Portugal e Espanha. Tais investigações passaram a defender que existe uma racionalidade própria do pensamento histórico, a qual parte de uma epistemologia específica que o fundamenta. Diferentemente da Psicologia da Educação, a Educação Histórica prioriza essa condição para compreender como pensam os jovens acerca da História, e de que forma se dá a aprendizagem neste campo do conhecimento. Busca-se, dessa forma, investigar a qualidade do conhecimento histórico, baseando-se em pressupostos teóricos e filosóficos. A valorização da quantidade e da correção no processo de aprendizagem dá lugar a uma análise relacionada aos raciocínios e à lógica do conhecimento.

Nesse sentido, a aprendizagem histórica se torna mais exigente e mais compensadora, por considerar alunos e professores como parte ativa do processo. Partindo destes pressupostos, diversas investigações contribuíram para qualificar a perspectiva da Educação Histórica. Dentre esses trabalhos, destacou-se uma proposta criada pela Prof.a Dr. ${ }^{a}$ Maria Isabel Barca, no ano de 1999: percebendo a importância de colocar o aluno como agente de sua própria formação, valorizando as suas ideias prévias e as suas experiências diversas no processo de construção do conhecimento histórico, a professora e pesquisadora portuguesa elaborou uma metodologia que congregou ensino e pesquisa, na intenção de diversificar e desafiar professores e alunos nas aulas de História. Essa proposta foi batizada de aula-oficina, e desde então vem sendo aplicada em diferentes contextos, tanto na Europa quanto em outras partes do mundo.

\section{A AULA-OFICINA E SUAS APLICAÇÕES}

Isabel Barca ministrava aulas na Universidade do Minho, no ano de 1999, quando organizou um modo de trabalhar que contemplasse as ideias desenvolvidas na formação de professores de História da Educação Básica em Portugal. A proposta consistia no seguinte: primeiramente, o professor selecionaria um conteúdo a partir do qual faria

${ }^{1}$ BARCA, 2004a. 
perguntas aos alunos sobre o que eles sabiam a respeito desse tema. Em seguida, viria a seleção das fontes históricas correspondentes a essa aula, orientando os alunos a analisar estes materiais para que fizessem inferências e comparações. A dinâmica objetivava envolver a todos no processo de investigação, os quais produziriam conclusões históricas que poderiam ser mais ou menos aproximadas àquelas realizadas pelos historiadores. No entanto, todas as hipóteses e tentativas de explicação deveriam ser valorizadas, avaliadas e reconceitualizadas, por intermédio do educador. As crianças e jovens, nesse sentido, tomariam consciência do que aprenderam e do que ainda faltaria aprender, bem como de quais aspectos gostariam de aprofundar e saber mais. A aula-oficina, portanto, partia da ideia de que o aluno deveria estar motivado e desafiado para poder aprender História ${ }^{2}$.

A aula-oficina pôs em prática a ideia de que os alunos precisam compreender que fonte é diferente de evidência. É a natureza das perguntas elaboradas que faz com que a fonte se torne evidência ${ }^{3}$. Ou seja, deve ficar claro que as evidências históricas nunca são dadas por si mesmas, mas produzidas pelas questões colocadas pela investigação histórica. Como lembra François Hartog, «dizer a "evidência da história” não será, por isso mesmo, suscitar uma dúvida, reservar espaço para um ponto de interrogação: será isso assim tão evidente» ${ }^{4}$ ? Na aula-oficina, o uso destas fontes ocorre em duas dimensões: primeiramente o uso da evidência (informação e inferência), quando os alunos dão sentido às evidências; e depois a consciência histórica que se forma a partir da relação dialógica entre passado e presente ${ }^{5}$.

A dinâmica do trabalho com as fontes na aula de História permite ao aluno compreender que os conceitos carregam uma bagagem temporal de passados particulares. Eles não são criados aleatória ou espontaneamente. As instituições, as nações ou qualquer outra categoria são entidades temporais que só podem ser explicadas e compreendidas através do conhecimento do passado. É ele que oferece razões para as ações humanas, sendo esta historicidade fundamental para que os estudantes compreendam o que significa aprender História ${ }^{6}$. O autor destaca que na História nada está previamente aprovado. Não existem condições previstas a partir das quais as ações humanas se realizam.

\footnotetext{
${ }^{2}$ NICOLIELO, 2013.

${ }^{3}$ ASHBY, Rosalyn (2001) - Children's ideas on evidence. Porto: Universidade Portucalense. Comunicação apresentada no Congresso dos Professores de História. Uma boa discussão sobre o conceito de evidência pode ser encontrada na obra de François Hartog, Evidência da História: o que os historiadores veem. O autor percorre as distintas acepções do conceito de evidência desde a antiguidade até a contemporaneidade sendo que o mais apropriado para os nossos propósitos é o sentido que aponta para as ideias de sinal, marca, prova ou testemunho do passado. «De natureza principalmente jurídica e judicial, mas também na área da medicina, esse registro tem sido utilizado pela história. Uma leitura dos primeiros capítulos de Tucídides é suficiente para fazer tal demonstração: não prescindindo, de modo algum, de indícios e provas, ele define a história como pesquisa e investigação, busca da verdade.» (HARTOG, 2011: 13)

${ }^{4}$ HARTOG, 2011: 11.

${ }^{5}$ BARCA, 2011.

${ }^{6}$ LEE, 2011.
} 
Desde o final do século XIX, historiadores e professores vêm concordando que a História deve ser crítica, mas este objetivo não chegou a ser contemplado satisfatoriamente no ensino, segundo defendem pensadores da Educação Histórica. Segundo essa avaliação, a disciplina escolar veio se afastando dos seus propósitos, privilegiando a memorização de fatos, datas e personalidades e o subsequente esquecimento por parte dos estudantes. Isso se insere em um contexto educacional em que o pensamento e a imaginação teriam sido abandonados, criando um abismo entre a teoria e a prática do ensino de História ${ }^{7}$.

Nessa perspectiva, é necessário que o ensino de História desenvolva competências nos estudantes, não prescrevendo, mas ajudando-os a perceber os caminhos da fundamentação e das perspectivas históricas para a compreensão da historicidade do ser humano. A partir desta situação, os alunos poderão olhar para o passado e voltar ao presente com novos olhares e novas possibilidades de compreensão da realidade. Um ensino de História que mostre que somos mais do que receptores passivos do conhecimento do passado 8 .

As diferentes culturas apresentam distintas formas de compreender o passado. Há uma tensão entre a oralidade e a escrita sobre esta temporalidade, que hoje se complexifica em função das mudanças aceleradas. Por isso, precisamos oportunizar aos alunos que eles entendam como funciona esse processo de construção das narrativas, e não apenas o seu produto final, que geralmente chega até eles na forma do livro didático e pela transmissão de informações por parte dos professores, predominantemente, mas, hoje, também por meio de outros recursos midiáticos, que assumem caráter de portadores de verdades históricas.

Os currículos escolares raramente prestam atenção aos métodos dos historiadores e às suas formas de pensar. A pergunta que devemos fazer é: por que a História não deveria ter métodos científicos? Isso leva a repensar como ensinamos este componente curricular nas escolas. Precisamos saber como os estudantes progridem do senso comum para ideias mais sofisticadas. Muitas vezes, eles não dominam o caminho de construção da História, perdendo a parte do desafio e da emoção na construção do conhecimento.

Partindo dessas questões que norteiam a atuação dos investigadores da Educação Histórica, compreendemos o significado que a proposta da aula-oficina assumiu nesses vinte anos (1999-2019) em que foi se incorporando e sendo repensada em diferentes situações. No Brasil, a metodologia foi utilizada em diferentes contextos ao longo desse período, cujos resultados foram registrados através de produções acadêmicas, principalmente. Dentre elas, destacamos algumas propostas desenvolvidas no Departamento de

\footnotetext{
${ }^{7}$ SEIXAS \& MORTON, 2013

${ }^{8}$ SEIXAS \& MORTON, 2013.
} 
História da Universidade Estadual de Londrina, no Brasil, que adotou essa proposta de forma mais sistemática na segunda década dos anos 2000:

Tabela 1. Aplicação da aula-oficina na Universidade Estadual de Londrina, Brasil

\begin{tabular}{l|l}
\hline \multicolumn{1}{c|}{ Produção } & \multicolumn{1}{c}{ Proposta } \\
\hline & $\begin{array}{l}\text { O trabalho partiu de uma troca de conhecimentos entre os } \\
\text { professores e os alunos do } 7 .^{\circ} \text { ano de uma escola de Maringá } \\
\text { (Paraná), buscando-se compreender o que os estudantes }\end{array}$ \\
$\begin{array}{l}\text { SPERANDIO, Amábile; SILVA, Naira Saiki (2013) } \\
\text { - Aula-oficina: história regional e memória no } \\
\text { âmbito escolar - experiência de proposta de } \\
\text { aula. In Anais da I Jornada Paranaense PIBIDe }\end{array}$ & $\begin{array}{l}\text { um trabalho com fontes de arquivos pessoais, visando } \\
\text { identificar a função da memória histórica e também como } \\
\text { PET de História. Maringá: Universidade } \\
\text { Estadual de Maringá. }\end{array}$ \\
$\begin{array}{l}\text { forma de aproximá-los do trabalho do historiador. A proposta } \\
\text { incluiu uma visita ao Museu Histórico de Londrina - uma } \\
\text { instituição de memória, e uma atividade final para avaliar os } \\
\text { efeitos da aula-oficina. }\end{array}$
\end{tabular}

CAINELLI, Marlene Rosa; TOMAZINI, Elizabete Cristina de Souza (2017) - A aula-oficina como campo metodológico para a formação de professores em história: um estudo sobre o PIBID/História/UEL. «História \& Ensino», vol. 23, n. 2 , p. 11-33.
Essa análise compreende a docência a partir dos pressupostos da Educação Histórica, em especial o modelo de aula-oficina e a sua utilização nas experiências do PIBID e, posteriormente, em sala de aula. As autoras realizaram entrevistas com os chamados pibidianos, que nesse momento já se encontravam atuando na Educação Básica e puderam avaliar a importância das experiências com a Educação Histórica e a aula-oficina em sua formação docente.

A proposta selecionada nesse texto foi direcionada para alunos do $7 .^{\circ}$ ano, através da utilização de diferentes documentos históricos acerca do tema escravidão negra no Brasil durante o século XVIII. As fontes selecionadas foram obras do francês Jean-Baptiste Debret, músicas da cultura popular brasileira Jorge Ben Jor e Clara Nunes - , além de vídeos e cantigas relacionadas à capoeira e à cultura negra. A metodologia desenvolvida incluiu discussões sobre diferentes construções históricas acerca do tema, evidenciando a importância da diversificação de fontes para a construção do pensamento histórico e da consequente orientação para a vida.

Em 2011, as autoras realizaram um estudo-piloto com alunos do 9..$^{\circ}$ ano. A partir desta experiência, elaboraram um estudo exploratório aplicado em 2012, na mesma escola e mesmo nível de ensino, elaborando em seguida um planejamento de aula-oficina com a utilização da música como fonte de investigação. As músicas secionadas foram do compositor e intérprete baiano Raul Seixas, cujas canções estão relacionadas ao período da Ditadura Militar, mas geralmente não são mencionadas em livros didáticos quando se trata dessa temática. A aula-oficina proposta promoveu a análise do conteúdo das canções de Raul Seixas, identificando críticas sociais e as suas relações com o contexto histórico em que foram produzidas. 
A expressão aula-oficina, portanto, foi adotada para estabelecer uma demarcação em relação às aulas meramente expositivas, que se aproximam do modelo praticado pelo ensino tradicional ou até mesmo pelo não-diretivo, em cuja dinâmica o aluno acaba tão somente repetindo informações que o professor oferece de forma centralizadora. Ao contrário dessa imposição, a aula-oficina permite a exploração e análise de ideias prévias dos alunos e do consequente processo de construção do pensamento histórico em aula, cujo ambiente é marcado pela perspectiva construtivista.

Porém, ao longo das duas décadas que transcorreram desde a criação dessa proposta construída por Isabel Barca, muitas mudanças ocorreram na escola e na compreensão do processo de ensino e aprendizagem. As próprias investigações da Educação Histórica foram ampliadas nesse percurso, incorporando novos problemas e abordagens. A sala de aula, igualmente, sofreu os impactos das novas formas de sociabilidade resultantes da interação com as tecnologias da informação, cujo processo de transformação acelerado produziu situações inexistentes no final do século XX.

Os alunos que hoje frequentam o ambiente escolar trazem consigo as novas linguagens produzidas pelas mídias digitais, as quais se tornaram também objeto de investigação no campo da Educação Histórica. Se antes o professor de História precisava encontrar formas de desafiar os estudantes e motivá-los no processo de construção do conhecimento histórico, hoje esse esforço requer também que pensemos sobre como ensinar História à geração conhecida como nativos digitais, ou seja, crianças e jovens que já nasceram interagindo com as novas tecnologias da informação e utilizam uma nova linguagem ao se comunicarem com professores, familiares e demais sujeitos que não são nativos digitais, mas buscam se adaptar à nova realidade.

Nesse contexto, pensamos que a aula-oficina, mesmo que não tenha sido proposta no atual contexto escolar, pode contribuir para a aprendizagem histórica a partir do uso dessas novas tecnologias e novas linguagens utilizadas pelos nativos digitais, criando canais de interação entre professores e alunos a partir do uso de fontes na aula de História. $\mathrm{Na}$ contramão da ideia de que a informatização anula a importância do passado e da consciência histórica, compreendemos que a metodologia proposta pode fazer dessa mudança uma possibilidade de revitalização da prática de ensino em História, desde que tenhamos consciência de que o papel do professor, antes centralizador, hoje precisa assumir uma função ainda mais dialógica e interativa, transformando aparentes distanciamentos em oportunidades de construção conjunta do conhecimento histórico na educação básica e no ensino superior. 


\section{OS NATIVOS DIGITAIS NA SALA DE AULA: UMA RELEITURA DA AULA-OFICINA À LUZ DA HISTÓRIA DIGITAL}

No Brasil, o debate sobre as diferentes linguagens no ensino de História tem ganhando cada vez mais força desde o final da década de 1980 e está diretamente ligado à busca de novas alternativas didáticas ao chamado «ensino tradicional» centrado em aulas expositivas. A princípio, isso aconteceu por meio do uso de diversos tipos de documentos históricos como recursos didáticos em sala de aula. O emprego de novas linguagens envolve também uma reconfiguração da relação entre professor e estudante, na qual o aluno não é visto como alguém passivo, mas como um sujeito que participa ativamente no processo de ensino-aprendizagem. Prova disso é a busca por um maior contato direto com documentos históricos de distintos suportes com o objetivo de que os estudantes participem ativamente da construção do conhecimento histórico escolar por meio da compreensão e interpretação das fontes, a exemplo da proposta da Educação Histórica ${ }^{9}$.

Além do mais, o debate sobre a incorporação da tecnologia ao ensino já chegou ao nível das políticas públicas educacionais. Das dez «competências gerais para a educação básica» citadas na última versão da BNCC, por exemplo, o termo digital/tecnologia aparece em quatro delas. Desde 2015 o PNLD contempla os objetos digitais de aprendizagem (ODA) que incluem videoaulas, jogos digitais e animações ${ }^{10}$. Os ODA são arquivos digitais usados para fins educacionais que ficam armazenados em repositórios digitais e disponíveis para professores, alunos e demais interessados ${ }^{11}$. A incorporação dos meios digitais aos currículos como eixo transversal tem crescido a tal ponto que a tendência, de acordo com Maria Elizabeth Almeida, é pensarmos em um webcurrículo. Isto é, mais do que somente recorrer a disponibilização de material didático na internet, a tendência atual é incorporar a lógica do pensamento digital aos currículos ${ }^{12}$.

Nesse contexto, acreditamos que a proposta de aula-oficina desenvolvida por Isabel Barca pode ser atualizada à luz dos debates em torno da chamada História Digital (Digital History). A História digital surgiu nos Estados Unidos em 1997 para se referir às abordagens que procuravam pesquisar e representar o passado empregando as novas tecnologias da comunicação. Em sua origem, a História digital estava ligada também ao ensino de História por meio de documentos históricos disponibilizados em meios digitais $^{13}$. Assumindo a íntima conexão entre pensamento e linguagem, podemos afirmar que a tecnologia digital não é uma mera ferramenta didática, mas uma linguagem, uma forma de pensar o mundo que tem importantes implicações para o modo como ensinamos História.

\footnotetext{
${ }^{9}$ ROCHA, 2015.

${ }^{10}$ COSTA \& GABRIEL, 2014.

${ }^{11}$ SOUZA, 2017.

${ }^{12}$ ALMEIDA \& SILVA, 2011.

${ }^{13}$ LUCCHESI \& LEAL, 2016.
} 
Atualmente, grande parte do público da educação básica é formada pelos chamados nativos digitais, isto é, jovens que nasceram no contexto de expansão das tecnologias e mídias digitais. Conforme Prensky ${ }^{14}$, os alunos nativos digitais pensam e processam informações de um modo diferente. Dentre as principais características do estilo de pensamento dos nativos digitais, podemos destacar: a) a capacidade para realizar múltiplas tarefas simultaneamente; b) a preferência por ler gráficos e imagens antes do texto, e não o contrário; c) leitura não-linear pela lógica do hipertexto. Além disso, os nativos digitais têm pouca paciência com preleções ou exposições de conteúdo mais extensas. Em virtude do intenso contato com a tecnologia e as redes sociais desde muito cedo, os estudantes contemporâneos são, digamos assim, falantes nativos da linguagem digital. Em contrapartida, os professores são imigrantes digitais. Ou seja, eles procuram se adaptar ao novo ambiente, embora continuem a manter um certo sotaque ao falar a linguagem digital, como, por exemplo, quando insistem na necessidade de imprimir um texto escrito no computador para editá-lo, ou mesmo ao ligar para alguém para conversar sobre um e-mail enviado. Sem dúvida, uma parte importante do desafio de uma aula de História na educação básica hoje passa por um problema de linguagem em que imigrantes e nativos procuram se entender.

Bem entendido, o diálogo com a linguagem digital não implica um abandono completo das antigas abordagens, mas uma atualização das competências ligadas ao processo de ensino-aprendizagem, especialmente no caso do conhecimento histórico. Para nossos propósitos, nesse texto sustentamos que é possível incorporar criticamente algumas características da História digital à aula-oficina tais como a interatividade, a colaboração, a autoridade compartilhada, a hipertextualidade e a multimídia.

Como se sabe, um dos pilares da aula-oficina é a leitura e a interpretação de fontes históricas em diversos suportes. Nesse sentido, acreditamos que a proposta das webquests ${ }^{15}$ criada em 1995 pelo estadunidense Bernie Dodge pode ser concebida como um exemplo de atividade didática de uma aula-oficina afinada com as tecnologias digitais. Como apontado pelas professoras Anita Almeida e Keila Grinberg ${ }^{16}$, as webquests são atividades de investigação que utilizam a pesquisa em fontes disponíveis na internet

\footnotetext{
${ }^{14}$ PRENSKY, 2001.

15 «A metodologia WebQuest foi criada em 1995, quando Dodge, ao coordenar um programa de capacitação de professores, colocou como uma das atividades a apresentação de um software educacional. Como expor o material e falar sobre ele não o contentavam, resolveu empreender uma abordagem diferente. Após reunir todas as informações necessárias sobre o software, criou um canal de comunicação via internet. Ainda assim, percebia a falta de "um contexto significativo, no qual as pessoas" pudessem "transformar informação disponível em conhecimento pessoal e substancial”. Na tentativa de superar esse entrave, criou uma situação em que os estudantes deveriam se imaginar como um tipo de consultor incumbido de avaliar e recomendar o material ao diretor da escola. O resultado da prática possibilitou-lhe perceber que os discentes alcançaram domínios mais expressivos do conteúdo e, além disso, demonstraram maior participação ao resolver colaborativamente o problema proposto na atividade.» (NASCIMENTO, 2018: 28-29).

${ }^{16}$ ALMEIDA \& GRINBERG, 2009.
} 
e que visam contribuir para o desenvolvimento do "pensamento histórico» nos estudantes. Certamente, o objetivo não é transformar os alunos em historiadores mirins, mas ajudá-los a adquirir habilidades ligadas à pesquisa, ao processamento de informação e à formulação de hipóteses.

O professor tem um papel importante nessa atividade, pois vai orientar os alunos e fornecer uma espécie de roteiro com questões a serem respondidas pelos alunos para que eles não se percam no mar de informações da web. Afinal, para usarmos uma metáfora, quando não há objetivos claros, a busca de conhecimento na internet pode se assemelhar a um sedento que procura beber água no oceano. Caso a grande quantidade de água (informação) não seja devidamente tratada e filtrada (procedimentos críticos com as fontes), ela pode acabar sendo imprópria para o consumo e causar algum tipo de afogamento.

Em linhas gerais, a webquest como metodologia de investigação orientada consiste em quatro elementos: introdução, tarefa, processo e avaliação. Na introdução os estudantes recebem as primeiras informações e identificam o conteúdo a ser trabalhado. $\mathrm{Na}$ tarefa, os alunos são apresentados ao personagem que irão interpretar, o qual pode ser um detetive, um historiador, um arqueólogo ou um jornalista investigativo. A tarefa é apresentada de maneira clara e exequível de modo que o estudante utilize a imaginação para solucionar a situação-problema. O processo consiste no conjunto de informações mobilizadas na tarefa que pode incluir documentos históricos digitalizados, vídeos, mapas, áudios, imagens etc. A avaliação/conclusão é a culminância do projeto, o momento em que os estudantes colaborativamente constroem algo que foi pedido para a resolução da tarefa.

De acordo com Dodge, as webquests podem ser divididas em dois grupos: as webquests curtas e as webquests longas. No primeiro grupo, o principal objetivo é a integração do conhecimento e a atividade deve ser planejada para ser executada no prazo de duas a três aulas. Assim, o foco é que o aprendiz entre em contato com um número significativo de informações e que produza sentido para essas informações. No segundo caso, os objetivos principais são a ampliação e o refinamento do conhecimento e a atividade deve ser planejada para ser executada entre uma semana e um mês de trabalho escolar. Dessa forma, o estudante investigador deve não apenas entrar em contato com uma massa de informações como também produzir um conhecimento significativo que outros possam utilizar futuramente.

No caso de uma aula-oficina de História, a webquest seria desenvolvida buscando uma maior interação com os pressupostos metodológicos da ciência histórica, sobretudo no que diz respeito à crítica documental e à produção de sentido para as informações tendo em vista a orientação existencial dos estudantes. Além do mais, essa interação torna necessário abrir um espaço maior para o acolhimento e processamento das ideias históricas dos estudantes. Isto é, uma vez que as webquests trabalham com 
a busca de soluções para situações-problema, no âmbito da Educação Histórica, nada mais apropriado do que colocar em prática aquilo que Jörn Rüsen chamou de «competência narrativa» da consciência histórica. "Essa competência pode se definir como a habilidade da consciência humana para levar a cabo procedimentos que dão sentido ao passado, fazendo efetiva uma orientação temporal na vida prática presente por meio da recordação da realidade passada ${ }^{17}$.» Assim, caberia aos estudos empíricos a investigação sobre o modo como a competência narrativa se desenvolve em webquests específicas.

\section{A AULA-OFICINA, A HISTÓRIA DIGITAL E A RECONFIGURAÇÃO DO PROFESSOR DE HISTÓRIA}

Sem dúvida, um dos principais legados deixados pela proposta de aula-oficina de Barca é a indicação de caminhos bem delimitados para que a relação entre professores e alunos deixe de ser uma via de mão única em que os primeiros são os únicos sujeitos ativos no processo de ensino-aprendizagem. Afinal, como salientava Paulo Freire, «ensinar não é transferir conhecimento, mas criar a possibilidade para a sua própria produção ou a sua construção» ${ }^{18}$. Não por acaso, pelo menos desde a segunda metade do século XX, os pensadores do campo da educação têm destacado que os alunos não são sujeitos passivos à espera do conhecimento e que os professores devem ser mediadores no processo de ensino-aprendizagem. Pois bem, tanto a aula-oficina como a História Digital acentuam ainda mais esse quadro, acrescentando que agora é preciso lidar com os nativos digitais que são capazes de produzir conteúdo e veicular suas próprias interpretações históricas nas redes sociais.

Definitivamente, nesse contexto, não cabe mais a figura do professor de História daquilo que Barca chamou de «aula-conferência», isto é, alguém que transmite informações sobre o passado para quem não tem acesso a essas informações, ainda mais se levarmos em consideração que uma das principais características da web 2.0 é o apagamento da fronteira entre o autor e o público, o produtor e o consumidor do conhecimento. Em vez disso, nossa hipótese, com base em argumentos discutidos pelo teórico brasileiro Valdei Araujo, é que atualmente a função do professor poderia ser pensada a partir da ideia do curador de histórias. Basicamente, isso significa que o professor atua como um mediador do conhecimento produzido de maneira colaborativa, juntamente com os estudantes. Assim, sua principal tarefa deixa de ser a transmissão de conteúdos e se torna a democratização das condições de produção de representações históricas. Em outras palavras, o professor como curador de histórias é um mediador que contribui para o desenvolvimento da autonomia dos estudantes, pois procura desenvolver as habilidades necessárias para a produção de representações históricas feitas pelos próprios estudantes.

\footnotetext{
${ }^{17}$ RÜSEN, 1992: 9.

${ }^{18}$ FREIRE, 1996: 47.
} 
O curador é aquele que acolhe, promove, seleciona e edita as histórias produzidas pelos alunos. Sua tarefa é criar um espaço propício para a ampliação das condições de produção do conhecimento histórico. Em meio a uma infinidade de informações disponíveis hoje na web, a figura do curador é fundamental para ajudar os estudantes na elaboração de critérios críticos para a seleção das informações. «O foco aqui seria menos a autoria e a produção, como na pesquisa, mas o acolhimento crítico e a amplificação de oportunidades e ferramentas ${ }^{19} . »$

Com efeito, isso requer a reformulação dos cursos de formação de professores de História com a incorporação de habilidades digitais ao currículo e também com a criação de laboratórios de comunicação digital do conhecimento histórico ${ }^{20}$. Além disso, é cada vez mais urgente que a formação de professores não se limite apenas à discussão de técnicas didáticas para a transmissão de conteúdos. Isto é, cada vez mais faz-se necessário incorporar à agenda da formação dos professores de História a compreensão da linguagem digital aplicada ao ensino, aliada a uma sólida base de teoria e metodologia da História. A curadoria de histórias tem importante justificativa epistemológica para os tempos atuais e também notável dimensão ético-política, pois as redes sociais têm sido utilizadas para a veiculação de interpretações históricas preconceituosas e baseadas em falsas evidências.

Tudo isso nos parece estar em consonância com os princípios da Educação Histórica, sobretudo no que diz respeito ao foco no desenvolvimento de competências investigativas tanto por parte de professores como de estudantes. Ademais, fica em evidência que a consciência histórica a ser trabalhada em uma aula-oficina afinada com a História Digital é uma forma histórica de ver o mundo e se orientar na vida prática a partir do encadeamento entre experiências e expectativas. A aproximação entre a figura do professor e a do curador de histórias é um esforço de atualização que muito pode contribuir para que a aula-oficina possa trilhar novos caminhos em sintonia com a lógica do conhecimento no mundo contemporâneo.

\section{BIBLIOGRAFIA}

ABREU, Marcelo; BIANCHI, Gustavo; PEREIRA, Mateus (2018) - Popularizações do passado e historicidades democráticas: escrita colaborativa, performance e práticas do espaço. «Tempo \& Argumento», vol. 10, p. 279-315.

ALMEIDA, Anita; GRINBERG, Keila (2009) - As webquests e o ensino de história. In GONTIJO, Rebeca; MAGALHÃES, Marcelo de Souza; ROCHA, Helenice Aparecida Bastos - A escrita da história escolar: memória e historiografia. Rio de Janeiro: Editora FGV.

ALMEIDA, Maria Elizabeth Bianconcini de; SILVA, Maria da Graça Moreira da (2011) - Currículo, tecnologia e cultura digital: espaços e tempos de web currículo. «Revista e-Curriculum», vol. 7, n. ${ }^{\circ} 1$ (abr.), p. 1-19.

\footnotetext{
${ }^{19}$ ARAUJO, 2017: 211.

${ }^{20}$ ARAUJO, 2017.
} 
ANUNCIAÇÃO, Ana Paula; SPERANDIO, Amábile (2012) - Aula-oficina: uma proposta de utilização de documentos históricos em sala de aula. In Atas do XII Congresso Internacional Jornadas de Educação Histórica: Consciência Histórica e as novas tecnologias da informação e comunicação. Curitiba: LAPEDUH/UFPR, p. 46-57.

ARAUJO, Valdei (2017) - O direito à História: o(a) historiador(a) como Curador(a) de uma experiência histórica socialmente distribuída. In GUIMARÃES, Géssica; BRUNO, Leonardo; PEREZ, Rodrigo, org. - Conversas sobre o Brasil: ensaios de crítica histórica. Rio de Janeiro: Autografia, p. 191-216.

BARCA, Isabel (2000) - O Pensamento Histórico dos Jovens: Ideias dos Adolescentes acerca da Provisoriedade da Explicação Histórica. Braga: CEEP/Universidade do Minho.

(2001) - Educação histórica: uma nova área de investigação. «Revista da Faculdade de Letras História», III Série, vol. 2, p. 13-21.

(2004) - Aula Oficina: do Projecto à Avaliação. In BARCA, Isabel, org. - Para uma Educação Histórica com Qualidade: Actas das IV Jornadas Internacionais de Educação Histórica. Braga: CIEd/Universidade do Minho; Instituto de Educação e Psicologia/Universidade do Minho, p. 131-144.

(2006) - Em torno da Epistemologia da História. In BARCA, Isabel; GAGO, Marília, org. — Questões de Epistemologia e Investigação em Ensino da História: Actas das 3. ${ }^{\text {as }}$ Jornadas Internacionais de Educação Histórica. Braga: CIEd/Universidade do Minho, p. 17-25.

(2009) - Educação Histórica: pesquisar o terreno, favorecer a mudança. In SCHMIDT, Maria Auxiliadora; BARCA, Isabel, org. - Aprender História: perspectivas da Educação Histórica. Ijuí: Ed. Unijuí, p. 53-76.

(2011) - Narrativas históricas de alunos em espaços lusófonos. In BARCA, Isabel, org. - Educação e Consciência Histórica na Era da Globalização. Braga: CIEd/Universidade do Minho; Lisboa: Associação de Professores de História, p. 7-27.

CAINELLI, Marlene Rosa; TOMAZINI, Elizabete Cristina de Souza (2017) - A aula-oficina como campo metodológico para a formação de professores em história: um estudo sobre o PIBID/História/UEL. «História \& Ensino», vol. 23, n. ${ }^{\circ}$ 2, p. 11-33.

COSTA, Marcela Albaine; GABRIEL, Carmen Teresa (2014) - Sentidos de «digital» em disputa no currículo de história: que implicações para o ensino desta disciplina? «Tempo e argumento», vol. 6, n. ${ }^{\circ} 12$.

DODGE, Bernie (1995) - Webquest: uma técnica para aprendizagem na rede internet. Tradução de Jarbas Novelino Barato. Disponível em <https://www.dm.ufscar.br/ jpiton/downloads/artigo_webquest_ original_1996_ptbr.pdf>. [Consulta realizada em 23/12/2019].

FERREIRA, Andreia (2010) - Elaboração de materiais didáticos mediados pelas tecnologias de informação e comunicação aplicadas à educação. In SALES, Júnia; RICCI, Cláudia, org. - Produção de materiais didáticos para a diversidade: patrimônio e práticas de memória numa perspectiva interdisciplinar. Belo Horizonte: UFMG/FAE/LABEPEH/CAED; Brasília: Secad/MEC.

FREIRE, Paulo (1996) - Pedagogia da autonomia: saberes necessários à prática educativa. São Paulo: Paz e Terra.

HARTOG, François (2011) - Evidência da história: o que os historiadores veem. Belo Horizonte: Autêntica Editora.

LEE, Peter (1994) - Progression in children's history. «Tsing Hua Newsletter for teaching history», vol. 3, p. 5-13.

(2011) - Why learn History? «Educar em Revista», n. ${ }^{\circ} 42$, p. 19-42.

LUCCHESI, Anita; LEAL, Bruno Pastor (2016) - História digital: Reflexões, experiências e perspectivas. In MAUAD, Ana Maria; ALMEIDA, Juniele Rabêlo de; SANTHIAGO, Ricardo, org. - História pública no Brasil: Sentidos e itinerários. São Paulo: Letra e Voz. 
NASCIMENTO, Éder Dias do (2018) - A metodologia WebQuest na aula de história. Campo Mourão, PR: UNESPAR - Universidade Estadual do Paraná, Programa de Mestrado Profissional em Ensino de História - PROFHISTÓRIA. Dissertação de mestrado.

NICOLIELO, Bruna (2013) - Isabel Barca fala sobre o ensino de História. «Revista Nova Escola». Disponível em <https://novaescola.org.br/conteudo/930/isabel-barca-fala-sobre-o-ensino-de-historia>. [Consulta realizada em 16/12/2019].

PRENSKY, Marc (2001) - Nativos digitais, imigrantes digitais. «On the Horizon», vol. 9, n. 5 (out.). MCB University Press. Disponível em $<$ http://www.colegiongeracao.com.br/novageracao/2_intencoes/nativos.pdf>. [Consulta realizada em 08/03/2019].

ROCHA, Helenice Aparecida Bastos (2015) - Linguagem e novas linguagens: pesquisa e práticas no ensino de História. In ROCHA, Helenice; MAGALHÃES, Marcelo; CONTIJO, Rebeca - O ensino de história em questão: cultura histórica e usos do passado. Rio de Janeiro: Fundação Getúlio Vargas.

RÜSEN, Jörn (1992) - O desenvolvimento da competência narrativa na aprendizagem histórica: uma hipótese ontogenética relativa à consciência moral. Tradução para o espanhol de Silvia Finocchio. Tradução para o português por Ana Claudia Urban e Flávia Vanessa Starcke. Revisão da tradução: Maria Auxiliadora Schmidt. Disponível em <https://edisciplinas.usp.br/pluginfile.php/1172513/mod_resource/ content/1/Jorn\%20Rusen\%20e\%20o\%20Ensino\%20de\%20Hist\%C3\%B3ria.pdf >. [Consulta realizada em 23/12/2019].

SEIXAS, Peter; MORTON, Tom (2013) - The Big Six Historical Thinking Concepts. Toronto: Nelson.

SIMONGINI, Jemima Fernandes; CORDEIRO, Marcela Taveira (2012) - Aula-oficina: a música como proposta de produção de conhecimento histórico com os alunos. In Atas do XII Congresso Internacional Jornadas de Educação Histórica: Consciência Histórica e as novas tecnologias da informação e comunicação. Curitiba: LAPEDUH/UFPR, p. 464.

SOUZA, Renato Fontes de (2017) - Objetos digitais de aprendizagem de História do Brasil para o Ensino Médio: uma proposta de roteiro avaliativo para o professor-curador. São Paulo: Pontifícia Universidade Católica de São Paulo. Dissertação de mestrado.

SPERANDIO, Amábile; SILVA, Naira Saiki (2013) - Aula-oficina: história regional e memória no âmbito escolar - experiência de proposta de aula. In Anais da I Jornada Paranaense PIBID e PET de História. Maringá: Universidade Estadual de Maringá. 



\title{
RESIGNIFICAR LA ENSEÑANZA Y EL APRENDIZAJE DE LA HISTORIA EN COLOMBIA. CAMINOS POSIBLES A PARTIR DE LA EDUCACIÓN HISTÓRICA
}

\author{
NILSON JAVIER IBAGÓN MARTÍN*
}

\begin{abstract}
Resumo: A partir de las discusiones curriculares que durante los últimos años se han comenzado a desarrollar en Colombia en torno al lugar que debe ocupar la enseñanza y el aprendizaje de la Historia en una sociedad en tránsito hacia la paz, se analizan las posibilidades epistémicas y prácticas que brinda la Educación Histórica para afrontar los retos que supone entender a profundidad un campo de indagación curricular poco explorado en el país. En consecuencia, la Educación Histórica se entiende en este contexto, como una posibilidad teórica y metodológica, que al permitir analizar de forma compleja las diversas variables que configuran la presencia o ausencia de la Historia en el sistema escolar, puede ayudar, en el caso colombiano, a fortalecer iniciativas educativas de resignificación de los sentidos y principios formativos que definen su enseñanza y aprendizaje.
\end{abstract}

Palabras clave: Educación Histórica; Aprendizaje histórico; Currículo; Colombia.

Abstract: From the curricular discussions that in recent years have begun to develop in Colombia around the place that the teaching and learning of History should occupy in a society in transit towards peace, the epistemic and practical possibilities offered by Historical Education are analyzed to face the challenges of understanding in depth a field of curricular inquiry little explored in the country. Consequently, in this context the Historical Education is understood, as a theoretical and methodological possibility, which by allowing a complex analysis of the various variables that make up the presence or absence of History in the school system, can help, in the Colombian case, to strengthen educational initiatives of resignification of the senses and formative principles that define its teaching and learning. Keywords: History Education; Historical learning; Curriculum; Colombia.

\section{INTRODUCCIÓN}

En Colombia, durante los últimos años, y en el contexto de la negociación, firma y desarrollo del acuerdo de paz entre el Estado y la guerrilla de las FARC - Fuerzas Armadas Revolucionarias de Colombia ${ }^{1}$ - , el debate público acerca de la necesidad y pertinencia de enseñar Historia se volvió a activar luego de un letargo considerable en torno a la discusión sobre este tema. En los diferentes niveles de formación del sistema educativo, esta prolongada falta de discusión curricular y académica, afectó

\footnotetext{
* Universidad del Valle (Colombia). E-mail: nilson.ibagon@correounivalle.edu.co.

${ }^{1}$ Las negociaciones iniciaron en septiembre del año 2012 y el acuerdo se firmó finalmente el 24 de noviembre del año 2016. En el ámbito educativo temas como la instalación obligatoria de una «cátedra de la paz» en todas las instituciones educativas del país, así como, la formulación de la ley 1874 de 2017 a través de la cual se restablece la enseñanza obligatoria de la Historia de Colombia, se apoyan en justificaciones derivadas implícitamente del acuerdo.
} 
negativamente - salvo contadas excepciones ${ }^{2}$ - los referentes epistémicos y metodológicos desde los cuales se pensó y piensa el aprendizaje y la enseñanza de la Historia en el país, a tal punto, que para algunos sectores el debate actual no tiene sentido, pues según estos, representa un retroceso curricular frente a los «avances» gestados desde la lógica oficial de enseñanza de las Ciencias Sociales escolares - que está vigente desde la mitad de la década de 1980.

A pesar que este último tipo de posicionamiento tiene una acogida importante en parte de la academia y de los gestores de política educativa, diferentes investigadores, grupos de investigación, programas académicos y maestros de escuela que venían desde hace algún tiempo desarrollando procesos de formación histórica con estudiantes de diversas edades, han comenzado a construir a través de la sistematización, socialización y discusión de sus trabajos, un campo de reflexión y acción investigativa específica que reivindica la importancia de enseñar y aprender Historia hoy. En el marco de este movimiento, los principios teóricos y prácticos provenientes de la corriente de investigación de Educación Histórica - History Education - , paulatinamente se han estado abriendo paso en algunos escenarios educativos, constituyéndose en una alternativa para pensar de forma compleja preguntas alrededor del qué, para qué, por qué y cómo enseñar y aprender Historia.

A partir de estos principios el Departamento de Historia de la Universidad del Valle, ha impulsado una serie de proyectos académicos de diversa índole y alcance, con el objetivo de dinamizar en la región - Valle del Cauca- y el país, reflexiones en torno a la didáctica de la Historia y el desarrollo del pensamiento histórico en la escuela. En este proceso ha sido fundamental, el contacto directo de algunos profesores del Departamento con los trabajos y propuestas de investigación de académicos de Brasil —LAPEDUH de la Universidad Federal de Paraná-, España —el grupo DiCSO de la Universidad de Murcia - y Portugal — Universidad de Minho y Universidad de Porto-; relación intelectual, que ha permitido a través de un intercambio fructífero de ideas, encontrar una base teórica sólida a través de la cual se ha fundamentado el inicio de la construcción de un camino propio de interpretación alrededor de lo que implica enseñar y aprender Historia en Colombia.

Dentro de este diálogo intelectual, el sostenido con la Doctora Isabel Barca y su obra ha sido especialmente importante, ya que, por un lado, ha permitido en los planos teórico y metodológico identificar con mayor claridad el lugar central que debe ocupar la epistemología de la Historia a la hora de pensar la didáctica de la disciplina y, complementariamente, en el plano de la acción, materializar proyectos e iniciativas académicas e investigativas orientadas a una efectiva difusión de estos principios de reflexión.

\footnotetext{
${ }^{2}$ Es necesario tener en cuenta que durante este periodo de aletargamiento se produjeron interesantes reflexiones acerca de la enseñanza de la Historia en el país, el problema radica en su número y alcance en términos de impacto curricular real.
} 
Un ejemplo de ello, fue la realización del XIX Congreso internacional de Educación Histórica en Agosto de 2019 en la ciudad de Santiago de Cali, evento cuya organización estuvo a cargo del Departamento de Historia de la Universidad del Valle. Estas jornadas que nacieron en Portugal bajo la dirección de la profesora Barca y que a lo largo de dos décadas se han constituido en un espacio de referencia internacional de debate alrededor de temas vinculados a la enseñanza y el aprendizaje de la Historia, en su decimonovena versión, además de permitirle a los participantes tener contacto directo con las ideas de investigadores destacados en el campo de la Educación Histórica, facilitó un proceso de (re)conocimiento de diversas iniciativas de investigación y formación que se adelantan en Colombia, Latinoamérica y Europa, las cuales, a pesar de su diversidad comparten un núcleo de fundamentación común: pensar históricamente es esencial para entender, ser y estar en el mundo.

El presente escrito, partiendo de este contexto específico, analiza la relevancia académica de la Educación Histórica en la búsqueda de nuevos sentidos para entender la enseñanza y el aprendizaje de la Historia en Colombia — país en el que el olvido se ha configurado en la base que define el presente y el futuro de su sociedad-, destacando la importancia del Congreso celebrado en Cali en dicho proceso. Para ello se han establecido dos ejes de argumentación: el primero realiza una breve descripción de los factores que durante las últimas décadas generaron un estancamiento de la producción académica alrededor de la didáctica de la Historia como campo específico de investigación en Colombia, y; en segundo lugar, a partir de la reactivación del interés por la enseñanza de la Historia en el país, se identifican algunos problemas del debate actual, con el fin de destacar algunas ideas fuerza provenientes de la Educación Histórica que permitirían resignificar los alcances epistemológicos de la discusión.

\section{LA ENSEÑANZA Y EL APRENDIZAJE DE LA HISTORIA COMO OBJETOS DE REFLEXIÓN ACADÉMICA EN COLOMBIA: OBSTÁCULOS Y DIFICULTADES}

En Colombia la enseñanza de la Historia y su aprendizaje entendidos como objetos de investigación y acción educativa, no han logrado consolidarse como un campo de reflexión con identidad propia. A diferencia de otros países de la región y, salvo algunos proyectos intelectuales e investigativos concretos desarrollados localmente, no existe un corpus epistémico y metodológico sólido, a partir del cual hoy se pueda entender de forma compleja, la presencia de la Historia en el currículo colombiano ${ }^{4}$. Aunque existen

\footnotetext{
${ }^{3}$ Véase la propuesta teórica y metodológica del profesor Darío Betancourt (1994). Asimismo, los desarrollos curriculares llevados a cabo por la Secretaria de Educación de Bogotá (2007) y la Secretaría de Educación de Medellín (2014), y algunos ejemplos de experiencias renovadoras que se pueden encontrar en recopilaciones realizadas por el IDEP (RODRÍGUEZ, ed., 2004; AA. VV., 2012).

${ }^{4}$ IBAGÓN \& MINTE, 2019.
} 
diversas causas que originan esta situación, para efectos del análisis propuesto se identifican dos problemáticas centrales: en primer lugar, la subvaloración de la investigación sobre la enseñanza y aprendizaje de la Historia por parte de historiadores y pedagogos ortodoxos, ha impedido en buena parte que la didáctica de la Historia se reconozca en el país como un campo de estudio de especial relevancia epistemológica; en segundo lugar, en Colombia desde hace treinta y cinco años se introdujo un cambio curricular en el que, la Historia entendida como saber escolar, fue «integrada» a las denominadas Ciencias Sociales escolares, situación que contrariamente a lo que se proyectaba al inicio de la reforma, ha impactado negativamente los niveles de discusión en torno a las lógicas particulares de funcionamiento teórico y práctico de la enseñanza-aprendizaje de la Historia. A continuación se exploran brevemente estas dimensiones problémicas.

\subsection{Entre el cuestionamiento disciplinar y el cuestionamiento pedagógico}

Los académicos que han centrado su interés investigativo en el análisis del funcionamiento y alcance formativo de la enseñanza y el aprendizaje de la Historia, han tenido que lidiar durante décadas con la subvaloración de sus hallazgos y aportes, por parte de sectores importantes de historiadores y pedagogos. En otras palabras, pensar la didáctica de la historia en tanto objeto de estudio, ha supuesto en Colombia situarse en un lugar de enunciación investigativo que es cuestionado desde el ámbito disciplinar por integrar racionalidades pedagógicas $\mathrm{y}$, desde el ámbito pedagógico, por integrar racionalidades disciplinares.

Así pues, a pesar que la enseñanza escolar de la Historia antecede y fue base de la formalización de la disciplina histórica en el país - creación de los primeros departamentos de Historia en las Universidades ${ }^{5}$, un porcentaje importante de los historiadores profesionales consideran que este objeto de estudio al incluir la pedagogía como parámetro de reflexión, no hace parte de su quehacer directo como intelectuales ${ }^{6}$. En consecuencia, lo asumen como un asunto que en términos académicos es de menor valor y rigor científico si se compara con los aportes historiográficos que realizan. Al interior de los departamentos de Historia, este tipo de concepciones ha dificultado la consolidación de líneas de investigación, programas de formación y espacios académicos específicos (revistas, congresos, etc.) en torno a la enseñanza y el aprendizaje de la disciplina.

Por otra parte, en un sistema escolar como el colombiano en el que la idea de interdisciplinariedad ha ganado fuerza - lo cual no es negativo per se-, algunos sectores

\footnotetext{
${ }^{5}$ ÁLVAREZ, 2007.

${ }^{6}$ Es necesario tener presente que existen algunos casos particulares que, por el contrario, han dedicado parte de sus esfuerzos investigativos a entender la relación entre la didáctica de la Historia y las bases epistemológicas de la disciplina. Sin embargo, son una minoría.
} 
académicos que han estructurado y defendido la propuesta de enseñar Ciencias Sociales reivindicando el lugar central de la pedagogía en el proceso, ven en la discusión sobre la enseñanza y el aprendizaje de la Historia un retroceso curricular. Dicho posicionamiento parte de la idea - cuestionable - que sostiene que la disciplinariedad es anacrónica frente a las necesidades de comprensión del mundo actual, hecho que la hace inútil y la despoja de sentido. A partir de esta perspectiva, todo ejercicio práctico y teórico desarrollado alrededor de la enseñanza de la Historia es juzgado como tradicional y carente de profundidad, pues se asume - erróneamente- de entrada que está basado en esquemas de memorización de datos y fechas.

\subsection{De la enseñanza de la Historia a la enseñanza de las Ciencias Sociales}

A inicios del siglo XX, en medio del proceso de consolidación del proyecto de estado-nación colombiano, la enseñanza de la Historia en el país fue clave para estructurar un sistema de identidad homogéneo ${ }^{7}$. Así pues, la «mitologización» curricular ${ }^{8}$ de la Historia en los planes de estudio oficiales de educación primaria y secundaria, se cimentó en objetivos formativos de carácter romántico ${ }^{9}$. Tales objetivos se materializaban en la difusión y memorización de «grandes» hazañas y procesos gestados por héroes del panteón nacional. Este modelo se fue fortaleciendo a lo largo del siglo XX y se potenció legislativamente en momentos de crisis social y política ${ }^{10}$. La enseñanza de la Historia se concibió entonces, como un medio efectivo para formar en niños y jóvenes un sentido de pertenencia a la patria, el cual estaba definido por una serie de arbitrarios culturales movilizados por las elites, en los que quedaban excluidas las experiencias históricas de grandes sectores de la sociedad (indígenas, comunidades afro, campesinos, mujeres, etc.).

Los principios mecánicos y memorísticos que fundamentaban este tipo de enseñanza de la historia — conocida como Historia Patria - , a inicios de la década del ochenta del siglo XX comenzaron a ser duramente cuestionados por una serie de académicos e intelectuales que defendían el valor formativo de la construcción de conocimiento por encima de su reproducción acrítica. En este sentido, su propuesta consistía en recuperar las voces de los olvidados introduciendo en la escuela lecturas más profundas y complejas de las realidades pasadas y presentes a través de un dialogo más cercano entre la Geografía, la Historia y la Economía. A partir de allí se impulsó la idea de integración curricular que daría paso a la enseñanza de las Ciencias Sociales escolares. Pese a la resistencia de sectores académicos tradicionales, encabezados por la Academia Colombiana

\footnotetext{
${ }^{7}$ ÁLVAREZ, 2007; HERRERA, 2007; IBAGÓN, 2016; MUÑOZ, 2013.

${ }^{8}$ GOODSON, 1991.

${ }^{9}$ VAN ALPHEN \& CARRETERO, 2015.

${ }^{10}$ IBAGÓN, 2019; RODRÍGUEZ, 2009.
} 
de Historia $(\mathrm{ACH})$, los cuales defendían la enseñanza de la Historia Patria, en 1984 -Decreto 1002 - se establecieron las bases de una reforma curricular que, amparada en las banderas de defensa de una educación transformadora, concretó la idea de integración $^{11}$. Es importante destacar que la Historia se entendía en el marco de esta reforma como el eje central del proceso de integración. No obstante, el peso de una larga tradición de enseñanza-aprendizaje afincada en la memorización de contenidos formales y la falta de claridad en las rutas de implementación de la política, hizo que las bondades teóricas de la reforma, al pasar el tiempo, se fueran relativizando al momento de aterrizarlas en el currículo y llevarlas a la práctica al interior de las instituciones educativas.

En medio de estas dificultades se fueron formulando pautas curriculares que, hasta el día de hoy, en vez de resignificar la enseñanza y el aprendizaje de la Historia, generaron un debilitamiento de la discusión en torno al lugar que debe ocupar la formación histórica de los estudiantes en la postura oficial de enseñar Ciencias Sociales. Ya sea, desde la idea de un tipo de interdisciplinariedad centrada en entender problemas presentes de forma atemporal - postura defendida en los Lineamientos Curriculares de Ciencias Sociales ${ }^{12}$ - , o el predominio de una perspectiva lineal de acumulación de contenidos substantivos - característica que define la propuesta de los Estándares Básicos Curriculares $^{13}$ y los recientes Derechos Básicos de Aprendizaje ${ }^{14}$ - los tres documentos curriculares que circulan actualmente como guías para pensar la enseñanza y el aprendizaje de las Ciencias Sociales escolares en Colombia, han generado un atraso considerable alrededor del desarrollo de un proyecto educativo nacional que promueva la formación del pensamiento histórico de los estudiantes.

\section{LA EDUCACIÓN HISTÓRICA: POSIBILIDADES PARA RESIGNIFICAR LA ENSEÑANZA Y EL APRENDIZAJE DE LA HISTORIA EN COLOMBIA}

Durante los últimos años, en reacción a las dificultades formativas que ha supuesto la disolución de la enseñanza de la Historia en el currículo oficial, comenzaron a surgir diversas voces críticas que reclamaban la «vuelta» de este saber escolar como asignatura independiente en los planes de estudio de educación primaria y secundaria. No obstante, son muy pocas las propuestas derivadas de esta reivindicación, que logran dar cuenta de la importancia de desarrollar el pensamiento histórico de los estudiantes a través de un trabajo que articule contenidos substantivos y contenidos meta-históricos. Por el contrario, hay una tendencia marcada en estas iniciativas, de centrar el interés formativo exclusivamente en la enseñanza y el aprendizaje de contenidos formales asociados a

\footnotetext{
${ }^{11}$ COLOMBIA. Ministerio de Educación Nacional, 1989.

${ }^{12}$ COLOMBIA. Ministerio de Educación Nacional, 2002.

${ }^{13}$ COLOMBIA. Ministerio de Educación Nacional, 2004.

${ }^{14}$ COLOMBIA. Ministerio de Educación Nacional, 2017.
} 
procesos y acontecimientos históricos concretos. Debido a ello, ha sido más fácil para los detractores de la enseñanza de la Historia justificar su rechazo a este tipo de propuestas, pues las relacionan con prácticas memorísticas y acríticas que han demostrado ser ineficientes en el pasado.

El desconocimiento de posturas teóricas y metodológicas rigurosas alrededor de la enseñanza de la Historia, por parte, tanto de sus defensores como de sus críticos - con algunas excepciones-, ha facilitado que los fundamentalismos de los dos sectores guíen la discusión, impidiendo así, un debate profundo que permita reconocer con claridad por qué es importante enseñar y aprender Historia. En este contexto, la Educación Histórica entendida como un área de investigación ${ }^{15}$, se ha comenzado a posicionar como una alternativa para reorientar y clarificar el debate. Esta posibilidad se ve expresada en cuatro puntos clave: en primera instancia, el lugar central que se le da a la epistemología de la ciencia histórica para pensar la didáctica de la Historia ${ }^{16}$, pone en cuestión el predominio que durante las últimas décadas han tenido la psicología y la pedagogía, al momento de definir el alcance formativo del aprendizaje histórico en el sistema educativo colombiano. Con ello, se amplía el espectro analítico sobre la enseñanza de la Historia, vinculando dimensiones de formación disciplinar que complejizan la acción educativa dentro y fuera del aula de clase; en segundo lugar, el paso de la contemplación a la acción, como indicador de aprendizaje $e^{17}$, permite evidenciar la conexión entre la Historia y la vida práctica, un punto esencial para entender la relevancia del conocimiento histórico en el siglo XXI; en tercer lugar, la recuperación de las ideas previas de los estudiantes y su agencia en el proceso formativo ${ }^{18}$, promueve ejercicios de enseñanza sustentados en el sentido que se le otorga a lo que se aprende; finalmente, entender al docente como un intelectual orgánico que investiga y construye conocimiento junto a sus estudiantes, rompe con la idea de una práctica educativa cimentada en la reproducción de información.

A partir de estos principios generales, el Departamento de Historia de la Universidad del Valle (Cali, Colombia) comenzó a estructurar desde hace algunos años una propuesta formativa (grado y posgrado) e investigativa, orientada a pensar de una forma compleja aspectos relacionados con la enseñanza y aprendizaje de la Historia. En medio de este proceso - que aún está en marcha—, las doctoras Isabel Barca y Maria Auxiliadora Schmidt, con quienes se ha mantenido un diálogo académico fructífero, consideraron oportuno que el Congreso Internacional de las Jornadas de Educación Histórica se llevara a cabo por primera vez en un país latinoamericano de habla hispana, postulando a la Universidad del Valle como sede de la decimonovena versión del evento. Desde el

\footnotetext{
${ }^{15}$ BARCA, 2001.

${ }^{16}$ BARCA, 2019; LEE, 2016; SCHMIDT, 2017; SCHMIDT, 2019.

${ }^{17}$ GERMINARI, 2016.

${ }^{18}$ BARCA, 2011; BARCA, 2019; OLIVEIRA, org., 2018.
} 
comienzo, tanto la formulación, como la aceptación de la invitación, se entendieron más allá de la celebración formal del Congreso. En otras palabras, los objetivos de esta iniciativa estuvieron centrados, por un lado, en establecer en el ámbito nacional, una ruptura epistémica alrededor de la discusión sobre la enseñanza y el aprendizaje de la Historia abordando teórica y metodológicamente problemas asociados al desarrollo del pensamiento histórico y la conciencia histórica ${ }^{19}$, y por otro, fortalecer en el plano internacional, el trabajo en red que ha venido posicionando a la Educación Histórica como corriente de investigación en Iberoamérica.

Aunque aún es temprano para hacer un balance a profundidad del cumplimiento de estos objetivos, desde una perspectiva de corto plazo ya se tienen evidencias de algunos resultados. A nivel nacional, se contó con la participación de ponentes adscritos a instituciones educativas (Universidades y Secretarias de Educación) de siete departamentos - Valle del Cauca, Bogotá, Risaralda, Nariño, Caldas, Tolima y Antioquia-, hecho que es significativo para el proceso de difusión de la Educación Histórica en el país. Se establecieron además una serie de alianzas institucionales que han permitido la estructuración de proyectos académicos conjuntos centrados en la Educación Histórica. Entre estos proyectos se destacan la coedición de libros, la proyección de programas académicos interinstitucionales de posgrado, y el establecimiento de posibles líneas de investigación que condensan intereses comunes de los académicos involucrados. Asimismo, en el plano internacional se afianzaron y ampliaron circuitos de producción investigativa que vienen funcionando con éxito desde hace algunos años. Desde esta perspectiva se destaca la participación que se tuvo de investigadores provenientes de México, Brasil, Chile, Costa Rica, España y Portugal.

\section{CONCLUSIONES}

La defensa del valor formativo de la enseñanza de la Historia en un contexto en el que se le ha restado importancia curricular - como es el caso de Colombia- no puede estar sustentada en aproximaciones carentes de fundamentación epistémica. Esto es, en principios de justificación que apelan a la necesidad de un conocimiento contemplativo vinculado a la necesidad de demostrar manejo de la cultura general. Por el contrario, cualquier iniciativa que reivindique la importancia de la formación histórica de niños y jóvenes, entendida como una acción fundamental del aparato escolar - teniendo claro que no es el único que interviene en el proceso- debe apoyarse en principios teóricos y metodológicos que den cuenta de la complejidad que implica la reorientación cognitiva ${ }^{20}$ que define a la enseñanza y el aprendizaje histórico. A partir de este principio, la Educación Histórica, se configura como una posibilidad de reflexión/acción teórica y

\footnotetext{
${ }^{19}$ Temáticas que en Colombia tienen poco desarrollo en el campo de la investigación educativa.

${ }^{20}$ LEE, 2016.
} 
metodológica, que permite entender la presencia de la Historia en la escuela más allá de cuestiones formales. Esta característica, que se ve reflejada en la posibilidad de pensar de forma distinta la circulación de conocimiento en el ámbito escolar y, por lo tanto, los roles de estudiantes y docentes, es la que produce finalmente una resignificación de la enseñanza y el aprendizaje.

A pesar que en Colombia aún es incipiente el dominio por parte de profesores e investigadores, de los elementos teóricos y prácticos de la Educación Histórica, escenarios como el establecido por las Jornadas celebradas en Cali en el año 2019, dejan de manifiesto que muchos de los proyectos de intervención e investigación que se están adelantando en el país en torno a la enseñanza de la Historia, tienen puntos de convergencia enormes con esta corriente. En este sentido, no es ilusorio proyectar en el mediano plazo un proceso de resignificación de la enseñanza de la Historia en el país, el cual amparado en el (re)conocimiento de las líneas generales de fundamentación de la Educación Histórica logre impactar el currículo de abajo hacia arriba.

\section{BIBLIOGRAFÍA}

AA. VV. (2012) - Historias que hacen Historia: Memorias del Simposio sobre la Enseñanza de la Historia. Bogotá: IDEP; OEI. (Serie Memorias IDEP).

ÁLVAREZ, Alejandro (2007) - Las ciencias sociales en el currículo escolar: 1930-1960. Madrid: UNED. Tesis de doctorado.

BARCA, Isabel (2001) - Educação Histórica: uma nova área de investigação. «Revista da Faculdade de Letras - História», III Série, vol. 2, p. 13-21.

(2011) - Educação Histórica: vontades de mudança. «Educar em Revista», n. ${ }^{\circ} 42$, p. 59-71.

(2019) - Narrativas históricas de los jóvenes: una cara de su orientación temporal. «Revista Historia y Espacio», vol. 15, n. ${ }^{\circ}$ 53, p. 309-332.

BETANCOURT, Darío (1994) - Enseñanza de la Historia a tres niveles. Una propuesta alternativa. Bogotá: Editorial Magisterio.

COLOMBIA. Alcaldía Mayor. Secretaría de Educación (2007) - Colegios Públicos de excelencia para Bogotá. Orientaciones curriculares para el campo de pensamiento histórico. Bogotá: Imprenta Nacional de Colombia. (Serie Cuadernos de Currículo).

COLOMBIA. Alcaldía de Medellín. Secretaria de Educación (2014) - El plan de área de Ciencias Sociales, Historia, Geografía, Constitución Política y Democracia. Medellín: Alcaldía de Medellín.

COLOMBIA. Ministerio de Educación Nacional (1989) - Marco General Ciencias Sociales: propuesta programa curricular Noveno Grado de Educación Básica. Bogotá: MEN.

(2002) - Lineamientos Curriculares de Ciencias Sociales. Bogotá D. E.: MEN.

(2004) - Estándares Básicos de competencias Ciencias Sociales. Bogotá: MEN.

(2017) - Derechos Básicos de Aprendizaje de Ciencias Sociales. Bogotá: MEN. Documento borrador.

GERMINARI, Geyso (2016) - Ideias de jovens do Ensino Médio sobre História. Um estudo na perspectiva da Educação Histórica. «Antíteses», vol. 9, n. ${ }^{\circ}$ 18, p. 67-86.

GOODSON, Ivor (1991) - La construcción social del currículum. Posibilidades y ámbitos de investigación de la historia del currículum. «Revista de Educación», n. ${ }^{\circ}$ 295, p. 7-37.

GUERRERO, Carolina (2011) - La enseñanza de la Historia en el contexto de las Ciencias Sociales en Colombia: de la tecnología educativa a las inteligencias múltiples (1970-2008). In GUERRERO, Javier; WEISNER, Luis, comp. — ¿Para qué enseñar Historia? Medellín: La Carreta, p. 189-208. 
HERRERA, Martha (2007) - El memorial de las identidades: entre héroes y villanos: en la busca de sí y de los demás también. «Folios», n. ${ }^{\circ} 25$, p. 53-61.

IBAGÓN, Nilson (2016) - Entre ausencias y presencias ausentes: Los textos escolares y el lugar de lo negro en la enseñanza de la historia de Colombia, 1991-2013. Bogotá: Pontificia Universidad Javeriana. (2019) - Una historia difícil de narrar. El periodo de la Violencia en los textos escolares de Ciencias Sociales. Cali: Programa Editorial Universidad del Valle.

IBAGÓN, Nilson; MINTE, Andrea (2019) - El pensamiento histórico en contextos escolares. Hacia una definición compleja de la enseñanza de Clío. «Zona Próxima», n. ${ }^{\circ}$ 31, p. 107-131.

LEE, Peter (2016) - Literacia histórica e história transformativa. «Educar em Revista», n. ${ }^{\circ} 60$, p. 107-146.

MUÑOZ, Mónica (2013) - El ciudadano en los manuales de historia instrucción cívica y urbanidad, 19101948. «Historia y Sociedad», n. ${ }^{\circ} 24$, p. 215-240.

OLIVEIRA, Thiago Augusto Divardim de, org. (2018) - Isabel Barca - Pensamento histórico e consciência histórica: teoria e prática. Curitiba: W. A. Editores.

RODRÍGUEZ, José Gregorio, ed. (2004) - Rutas Pedagógicas de la Historia en la educación básica de Bogotá. Bogotá: Universidad Nacional de Colombia; IDEP.

RODRÍGUEZ, Sandra (2009) - El 9 de Abril en las políticas de la memoria oficial: el texto escolar como dispositivo del olvido. In AYALA, César; CASALLAS, Óscar; CRUZ, Henry, eds. - Mataron a Gaitán: 60 años. Bogotá: Universidad Nacional de Colombia, p. 135-154.

SCHMIDT, Maria Auxiliadora (2017) — ¿Qué hacen los historiadores cuando enseñan la historia? Contribuciones de la teoría de Jörn Rüsen para el aprendizaje y el método de enseñanza de la Historia. «Clío \& Asociados», n. ${ }^{\circ} 24$, p. 26-37.

(2019) - El turno de la didáctica de la historia: contribuciones para un debate. «Historia y Espacio», vol. 15, n. $^{\circ} 53$, p. 21-42.

VAN ALPHEN, Floor; CARRETERO, Mario (2015) - The Construction of the Relation Between National Past and present in the Appropriation of Historical Master Narratives. «Integrative Psychological Behavioral Science», n. ${ }^{\circ}$ 49, p. 512-530. 


\section{II \\ CONTRIBUTOS NACIONAIS}





\title{
EDUCAÇÃO HISTÓRICA E FORMAÇÃO INICIAL DE PROFESSORES
}

\author{
LUÍS ALBERTO MARQUES ALVES*
}

\begin{abstract}
Resumo: A Formação de Professores de História, no tempo longo que nos traz das Ciências Pedagógicas aos atuais Mestrados em Ensino, foi o melhor laboratório onde foi sendo pensada, consolidada e validada a Educação Histórica. Primeiro como espaço epistemológico estranho e discutível. Depois como terreno fértil para transformar sementes em abundantes colheitas. Os «estagiários», os "orientadores»e os «supervisores», todos agentes deste processo, foram capazes de merecer a herança dos(as) pioneiros(as) portugueses(as) como Isabel Barca e consolidarem um espaço científico, hoje inquestionável. Do caminho na FLUP dá-se conta neste ensaio.
\end{abstract}

Palavras-chave: Formação; Professor; História; Educação histórica; FLUP.

Abstract: The training of History Teachers, in the long time that brings us from Pedagogical Sciences to the current Masters in Teaching, was the best laboratory where Historical Education was thought, consolidated and validated. First as a strange and debatable epistemological space. Then as a fertile ground, turning seeds into abundant crops. "Interns», "tutors» and "supervisors», all agents of this process, were able to deserve the heritage of Portuguese pioneers such as Isabel Barca and consolidate a scientific space that is today unquestionable. This essay addresses this path at FLUP.

Keywords: Training; Teacher; History; Historical education; FLUP.

Dizia-nos Isabel Barca em 2012 que «a Educação Histórica pressupõe uma aposta na inter-relação da teoria e práticas de Ensino de História, situando-se a investigação na sua interface» ${ }^{1}$.

O último quartel do século XX e as duas primeiras décadas do XXI constituíram o momento nevrálgico para a afirmação de um espaço epistemológico que saiu do seu sincretismo adolescente para uma cientificidade adulta e consistente, roubando aos descrentes argumentos para a sua marginalização ou até inviabilização. Os verdadeiros espaços científicos afirmam-se pela rutura epistemológica mas também pela consistência da sua construção. Um edifício científico tem fundações que vão até um objeto próprio, tem pilares cuja robustez se pode aferir pela sua metodologia e pela credibilidade dos seus construtores (investigadores), tem coberturas que são sínteses visíveis para todos, mas contempla também janelas e portas por onde podem entrar novos contributos para uma terminologia concetual que se vai enriquecendo, na mesma medida em que vai tendo mais habitantes (agentes, adeptos...).

\footnotetext{
* CITCEM/FLUP.

${ }^{1}$ BARCA, 2012: 37.
} 
A Educação Histórica foi-se construindo na confluência de vários saberes, mas também nos contributos de vários quadrantes científicos. A capacidade sincrónica de sintetizar e aproveitar os contributos do construtivismo, da epistemologia do saber histórico, da contextualização das várias ciências sociais, das metodologias de análise de dados, qualitativas e quantitativas, intensivas e indutivas, da Psicologia Cognitiva, mas também de assumir sempre a fluidez pós-moderna de algo em permanente construção, permitiu-lhe hoje estar na base da construção de um novo conhecimento histórico, de patrocinar uma nova Didática, de garantir uma outra função social para o saber histórico.

Um dos laboratórios onde este objeto - Educação Histórica - melhor tem sido analisado e construído é sem dúvida na área da formação inicial de professores de História, de modo particular a partir da Reforma de Bolonha em 2007. Entremos nesse espaço privilegiado onde os investigadores sociais em formação apresentaram alguns resultados que, embora sempre não definitivos, ajudaram a fornecer hipóteses para experiências futuras, dando, no presente, consistência à sua intervenção, através de uma permanente e necessária reflexividade.

\section{FORMAÇÃO, INVESTIGAÇÃO OU SIMPLES CONCEITO DE UNIVERSIDADE?}

O trajeto da formação inicial de professores para o $3 .^{\circ}$ ciclo e secundário nas Faculdades de Letras passou, desde os anos 70 do século XX, por várias fases que ajudaram a evidenciar o papel da aprendizagem, colocando-a ao mesmo nível do ensino. Inicialmente havia a licenciatura realizada na Universidade e obtida após quatro ou cinco anos de formação científica. Depois tivemos, para obtenção da profissionalização, a necessidade da frequência do curso de Ciências Pedagógicas com a duração de um ano e com um currículo que passava sobretudo pelas Cadeiras das Ciências Pedagógicas: Pedagogia e Didática (Anual); História da Educação, Organização e Administração Escolares (Anual), Introdução à Psicologia (Anual), Psicologia Escolar e Medidas Mentais (Anual) e Higiene Escolar (Semestral) num total de 19 horas letivas semestrais. Os anos 80, sobretudo após a Portaria 659/88 de setembro, começam a transfigurar a formação inicial de professores, destacando a necessidade de assegurar uma preparação adequada aos professores do $3 .^{\circ}$ ciclo do ensino básico e do ensino secundário, daqui se inferindo que teria de haver uma clara articulação entre a sua formação e as necessidades dos alunos, das escolas e dos conteúdos curriculares e programáticos onde esses alunos/professores iam lecionar. $\mathrm{O}$ aluno começa aqui a ganhar um espaço de identidade e atenção, bem como as especificidades dos territórios educativos onde a prática ia concretizar-se. Esta mudança concetual teve naturalmente repercussões também na profissionalidade docente permitindo incluir as competências nas áreas das várias Ciências da Educação, das Didáticas específicas das várias disciplinas e de um estágio pedagógico entendido como um processo prático de ensino e aprendizagem contextualizado (pela supervisão 
das Faculdades e a orientação de docentes mais experientes das Escolas), entendendo-se ainda como complementar, mas importante, a aquisição de hábitos de pesquisa e investigação, não dispensando depois uma formação contínua permanente e atualizada:

a concepção do saber que está implícita nesta posição e a concepção da função do professor adaptam-se mal às realidades actuais [...] A concepção dogmática de um saber feito é substituída pela concepção de um saber em evolução, a concepção disciplinar dá lugar à interdisciplinaridade e um novo espírito científico se vai formando [...] O professor deixa de ser o guardião dos valores tradicionais para ser agente influenciador de um processo de transformação social ${ }^{2}$.

Esta fase foi muito importante porque provocou, no interior de instituições com uma autoridade inquestionável «sobre» o saber científico específico das diferentes áreas, uma discussão em torno das "ciências menores» ditas de Educação. A incorporação, por necessidade, de docentes requisitados oriundos do terreno das escolas favoreceu essa análise, sempre marcada pelo ceticismo face aos «intrusos» e cujo desenlace mais importante foi o lugar neutro (ou menos polémico) que foi encontrado para a inscrição das Didáticas (ora em Departamentos ou Secções de Educação, ora nos tradicionais). Reinavam opiniões muito críticas relativamente à forma como as Faculdades encaravam o ramo educacional e evidenciavam-se alguns anacronismos, científicos, de espaços e fundos bibliográficos ou da própria carreira académica. Reflexão muito interessante no interior da instituição universitária, considerava-se que não era legítimo que as cadeiras científicas fossem desenvolvidas e lecionadas à revelia dos conteúdos programáticos do ensino básico e secundário. Do lado universitário dizia-se que era ridículo, por exemplo, que se mudassem os programas sem o mínimo conhecimento do que efetivamente se lecionava (e investigava) nas Faculdades. Embora se reconhecesse que estas não podiam ensinar tudo, não se podia inverter isto ao ponto de não lecionar e esperar que os alunos recém-formados tivessem uma elevada capacidade de autoformação, sobretudo quando o ensino nas Universidades não era feito com base nesse pressuposto e, mesmo hoje (2020), está ainda longe. Era claramente um conceito de ensino universitário que continuará a perdurar, muito para além desta discussão, como ainda recentemente Jorge Ramos do Ó nos lembrava:

A universidade em que estamos, em Portugal, pouco absorveu de práticas de vida comunitária centradas na consciência dos processos criativos que se aprofundaram noutros domínios da realidade cultural e artística. [...] O figurino da universidade moderna [...] postula, para além da independência académica, vinda da 
Idade Média, uma prática de afirmação problematizadora de todo o conhecimento, de uma busca da verdade sem constrangimentos ou limites de partida. Na universidade, nada deveria estar fora do questionamento, da discussão, da reelaboração. É preciso que saibamos, cada um a seu modo, assumir não apenas um princípio de resistência, mas uma força de resistência e de dissidênciaª

Era, no entanto, consensual que um verdadeiro ramo educacional teria de encurtar as distâncias entre a Faculdade e as escolas. Entre o que se aprendia e o que se teria de ensinar. Teria de haver uma efetiva articulação entre investigação e produção científica na área da História, por um lado, e os programas escolares, por outro.

\section{O PROCESSO DE BOLONHA E AS ALTERAÇÕES RADICAIS NA FORMAÇÃO DE PROFESSORES DE HISTÓRIA}

A inclusão num espaço europeu de formação universitária permitiu-nos, por um lado, abrir fronteiras aos nossos estudantes em termos de circulação e de diversidade na sua formação, mas também implicou a submissão a regras europeias de uniformização de graus, duração de curso, conteúdos... que abanaram a tradicional autonomia reivindicada pelas instituições de Ensino superior nacionais.

A Carta Magna das Universidades Europeias, subscrita em Setembro de 1988 pelos Reitores das Universidades Europeias, reunidos em Bolonha a propósito das comemorações dos novecentos anos da Universidade mais antiga do globo, tomando em consideração que o futuro da humanidade depende, em larga medida, do desenvolvimento cultural, científico e técnico que se forja nos centros de cultura, do conhecimento e de investigação em que as verdadeiras universidades se tornaram [...] proclama que os Povos e os Estados devem, mais do que nunca, tomar consciência do papel que as universidades serão chamadas a desempenhar numa sociedade em procura continua de transformação e internacionalização ${ }^{4}$.

Na sequência destes princípios, a Declaração de Bolonha foi subscrita em junho de 1998 pelos Ministros de Educação de 29 países europeus, para «num horizonte temporal de dez anos» ${ }^{5}$ criar um «Espaço Europeu de Ensino Superior coeso, harmónico, competitivo e atractivo, com a finalidade genérica de promover a mobilidade dos estudantes e demais agentes educativos $»^{6}$. Do lado mais académico e científico, o grande salto qualitativo e quantitativo protagonizado pelas Ciências da Educação e, no caso específico da

\footnotetext{
${ }^{3}$ Ó, 2019: 41-42.

${ }^{4}$ SIMÃO et al., 2005: 25.

${ }^{5}$ SIMÃO et al., 2005: 39.

${ }^{6}$ SIMÃO et al., 2005: 39.
} 
História, evidenciado pelas correntes da Educação Histórica, determinavam a criação, a seguir a uma licenciatura em História de 3 anos, um segundo ciclo, mestrado, especializado na formação de docentes para o $3 .^{\circ}$ ciclo e secundário, ficando os Institutos Politécnicos que incorporaram as Escolas Superiores de Educação responsáveis pela formação para o pré-escolar, $10^{\circ}$ e $2 .^{\circ}$ ciclos.

À revelia de tudo o que parecia mais normal, dentro do atribulado processo de Bolonha, a Ministra da Educação - Maria de Lurdes Rodrigues - e o seu Secretário de Estado - Valter Lemos - protagonizaram uma decisão polémica que obrigou a criar um segundo ciclo profissionalizante englobando a História e a Geografia. O Mestrado em Ensino de História e Geografia, organizado, por exemplo, pela Faculdade de Letras da Universidade do Porto (como noutras Faculdades), era um segundo ciclo profissionalizante que visava conferir habilitação profissional para a docência nos ensinos básico e secundário, na área da História e da Geografia. Este ciclo de estudos promovia o desenvolvimento de competências científicas e pedagógicas necessárias ao exercício da função docente, articulando o processo de ensino e aprendizagem com as exigências de qualificação do corpo docente decorrentes das transformações legais e procurando responder às mudanças da sociedade, da educação e da evolução científica e tecnológica. No Mestrado destacava-se como intenção final o desenvolvimento de um marco concetual estruturante e a familiarização com procedimentos vários que permitissem uma progressiva autonomia no saber-evoluir docente. Para tal promovia-se: a ampliação e a atualização de conhecimentos em História e em Geografia; a aquisição de conhecimentos e o contacto com metodologias nas áreas da Educação e da Didática; a transposição de saberes para contextos escolares; a análise reflexiva e crítica de situações e vivências escolares, em geral, e de ensino, em particular.

Consideravam-se áreas constitutivas desta formação: a Formação Educacional Geral; Didáticas específicas da História e da Geografia; Iniciação à prática profissional, incluindo a prática de ensino supervisionada; e Formação (complementar) na área da docência (História e Geografia). As duas primeiras áreas eram privilegiadas no primeiro ano do Curso, reservando-se as restantes sobretudo para o 2..$^{\circ}$ ano. Considerava-se que a Formação Educacional Geral e as Didáticas específicas eram áreas estruturantes da Iniciação à Prática Profissional, pelo que a deviam preceder. A Iniciação à Prática Profissional era entendida como um projeto anual, de modo a proporcionar ao aluno o contacto com a vivência docente e educativa ao longo do ano escolar. Não obstante, contemplava-se a possibilidade de, ainda no $1 .^{\circ}$ ano, os alunos poderem observar, colaborar, analisar e refletir sobre situações educativas concretas. A Formação (complementar) na Área da Docência deveria proporcionar o aprofundamento e complemento dos conhecimentos científicos adquiridos no primeiro ciclo, em articulação com os conteúdos programáticos da área em que o aluno estava a efetuar a prática profissional, preparando-o para uma crescente autonomia e capacidade de atualização no âmbito da formação contínua. 
Entendia-se que haveria vantagem de esta componente acompanhar a referida Iniciação à Prática Profissional, para melhor responder a dificuldades científicas que os estudantes pudessem enfrentar no exercício da referida Iniciação.

Todas as modificações que a formação de professores na área de História e Geografia sofreu não foram consensualizadas, nem com Universidades, nem com as Associações de Professores de História e Geografia. Será importante esclarecer que tanto umas como outras mostraram argumentos claros de resistência a esta proposta definida centralmente ${ }^{7}$. Para ingressar neste Mestrado de História e Geografia, os estudantes teriam de, nas licenciaturas, realizar um «minor» e um «major»: por exemplo 60 ECTS em Geografia e 120 em História ou ao contrário.

Manifestamente esta proposta tinha vários problemas: uma, reduzir custos na formação mas implicando uma menor competência científica dos profissionais (claro triunfo das Ciências da Educação sobre as áreas científicas mais tradicionais e específicas, no caso de História e Geografia); outra era potenciar a junção num mesmo grupo de recrutamento dos docentes de História e Geografia, podendo «usá-los» consoante as necessidades das Escolas; outra ainda era retirar às Faculdades mais tradicionais na formação de professores para o Ensino secundário e $3 .^{\circ}$ ciclo o monopólio da formação, face até a algumas reivindicações dos Politécnicos que se consideravam habilitados para formar professores para todos os ciclos de estudos. Fruto da experiência na formação de professores e no espírito de cooperação entre os vários «ramos» de formação profissional, foi possível retirar algumas vantagens deste processo: potenciar na área de formação comum o convívio entre estudantes das diferentes áreas científicas (na vertente da formação educacional geral); cooperar nos mestrados bidisciplinares com outras realidades epistemológicas, tentando minimizar o impacto das diferenças nos futuros profissionais; garantir, sobretudo na produção do Relatório Final, o intercâmbio entre a Educação Geográfica e a Educação Histórica, aproveitando as sinergias e as virtualidades de cada uma. Daqui resultaram bons relatórios de reflexão interdisciplinar potenciando ainda atividades nos Projetos Educativos das Escolas de cooperação entre as Ciências Humanas e Sociais ${ }^{8}$.

\footnotetext{
${ }^{7} \mathrm{O}$ enquadramento legal definido centralmente passava pelos seguintes diplomas: Portaria 256/2005 de 16 de março, que atualiza a «Classificação Nacional das Áreas de Educação e Formação»; Decreto-Lei 74/2006 de 24 de março, com «Normas técnicas para a apresentação de estruturas escolares e dos planos de estudos superiores e sua publicação»; Despacho 7287-C/2006, que explicita as "Normas de organização dos processos referentes ao registo de adequação dos ciclos de estudos», publicado em 31 de março de 2006; o Decreto-Lei 43/2007 de 22 de fevereiro, que «aprova o regime jurídico da habilitação profissional para a docência na educação pré-escolar e nos ensinos básico e secundário» (criando o mestrado bidisciplinar para a habilitação de professores de História e Geografia num único ciclo de estudos); e o Decreto-Lei 79/2014 de 14 de maio, que reverte a situação aprovando «o regime jurídico da habilitação profissional para a docência na educação pré-escolar e nos ensinos básico e secundário», mas agora em mestrados diferentes e monodisciplinares para as áreas de História e Geografia.

${ }^{8} \mathrm{Na}$ Faculdade de Letras da Universidade do Porto foram defendidos, entre 2010 e 2017, cerca de 110 Relatórios Finais deste Mestrado em Ensino de História e Geografia.
} 
Na sequência do Decreto-Lei 79/2014 de 14 de maio, surgiu o Mestrado em Ensino de História (3. ${ }^{\circ}$ ciclo do Ensino Básico e Ensino Secundário), onde, logo no preâmbulo, se aceitava o erro cometido por parte do poder político com a decisão de 2007 quando obrigaram à junção da formação de História e Geografia para o 3. ciclo e secundário, no mesmo ciclo de estudos. A justificação era clara e vinha ao encontro das muitas críticas veiculadas antes (em 2007) e posteriores aquando da sua implementação e verificação no terreno da formação inicial, em particular a deficiência das práticas pedagógicas dos estudantes obrigados às duas valências científicas:

Entre as alterações introduzidas [...] procede-se ao desdobramento do mestrado em Ensino da História e da Geografia no 3. ${ }^{\circ}$ ciclo do Ensino Básico e no Ensino Secundário, desdobramento que está ajustado aos grupos de recrutamento e que permite reforçar a formação na área da docência ao nível da habilitação de ingresso, e à eliminação de mestrados sem correspondência com os grupos de recrutamento?.

Tratando-se agora de um Mestrado monodisciplinar, houve claramente a preocupação de centrar todo o processo não apenas nas componentes de formação definidas no art. ${ }^{\circ} 7$ - Área de docência; área educacional geral; didáticas específicas; área cultural, social e ética; e iniciação à prática profissional - mas sobretudo garantir que este segundo ciclo pudesse trazer um complemento de formação científica (área de docência) de acordo com as realidades dos vários programas da disciplina de História no Ensino Básico e Secundário ${ }^{10}$. Como Mestrado profissionalizante de Ensino em História, atualmente em pleno funcionamento (2020), procura preparar os futuros docentes para a lecionação da disciplina de História no $3 .^{\circ}$ ciclo do ensino básico e ensino secundário. No secundário, face à possibilidade de lecionar História A, História B, História da Cultura e das Artes, procurou-se estruturar um currículo que fosse complementar de conteúdos e competências obtidas na licenciatura. É visível a inscrição de UC de âmbito especificamente económico, perspetivando a História B dos cursos de Economia e Gestão, mas também a História da Cultura e das Artes para a área específica do secundário. Estas particularidades que procuram distinguir o projeto educativo da FLUP de outras instituições de Ensino superior são visíveis também noutras áreas de formação, como por exemplo nas Didáticas, onde se procura criar condições para os futuros professores prepararem recursos específicos para estas vertentes.

\footnotetext{
${ }^{9}$ Preâmbulo do Decreto-Lei 79/2014. «D. R. I Série». 92 (2014-05-14) 2820.

${ }^{10}$ Relembre-se aqui que, para além de História como disciplina no 3. ${ }^{\circ}$ ciclo do Ensino básico, existe no Ensino secundário a História A (para os cursos de Línguas e Humanidades), a História B (para os cursos de Ciências socioeconómicas) e a História da Cultura e das Artes (vocacionada para o curso de Artes Visuais). Mais pormenores das matrizes destes cursos em <http://www.dge.mec.pt/cursos-cientifico-humanisticos>. [Consulta realizada em 07/01/2020].
} 
Com a «libertação» da Geografia, a área das Didáticas permitiu uma outra ousadia e garantir uma maior atualidade de recursos para os futuros docentes. Se as duas cadeiras de Didática da História (I e II) permitiram vocacionar a primeira mais para a planificação e produção de recursos e a segunda mais para os diferentes tipos de avaliação, as outras permitiram arriscar num sentido mais de futuro. Seja o futuro imediato do segundo ano do mestrado, onde a prática profissional é uma realidade - e para isso a UC de «Aplicações Didáticas em História» permite ensaiar situações o mais realistas possível daquilo que vão encontrar, numa perspetiva metodológica de «learning by doing» —, já a «Web e o Ensino da História» privilegia o carácter eminentemente prático desta unidade curricular, procurando orientar o desenvolvimento das aprendizagens dos estudantes para a descoberta, exploração e manuseio das ferramentas disponibilizadas pela Web. Esta UC fornece ainda competências para a produção de portefólios digitais correspondentes a toda a prática pedagógica relativa ao segundo ano. Embora lecionada no $1 .^{\circ}$ semestre do $2 .^{\circ}$ ano, neste Mestrado houve a possibilidade de incluir uma outra UC, entendida como fundamental, tanto para esta visão global das Didáticas como de aproximação científica ao Quadro teórico que depois vão desenvolver no Relatório Final. Trata-se de Perspetivas em Educação Histórica, pensada para atingir os seguintes objetivos: compreender paradigmas educativos diversificados para o ensino da História; analisar o conteúdo e as implicações do quadro concetual da Educação Histórica; alargar o seu campo de visão para diferentes perspetivas de análise do ensino da História; conhecer investigações nacionais e internacionais no âmbito da Educação Histórica; avaliar a importância das investigações já concretizadas no alargamento do quadro teórico e conceptual; delinear um projeto de investigação no âmbito da Educação Histórica. Esta unidade curricular visa alargar horizontes de paradigmas educativos, de práticas de ensino e de reflexões divergentes sobre a Didática da História. Nesse sentido, procura-se enfatizar uma vertente socioconstrutivista da aprendizagem, uma prática de ensino que privilegie a aprendizagem como elemento mais importante, diluindo a aposta, por vezes exclusiva, no ensino, que crie condições epistemológicas para uma prática reflexiva e que forneça informações teóricas e de práticas investigativas que torne mais consciente a opção pelo tema e pela metodologia de investigação do relatório final do Mestrado. Este objetivo final significa também a possibilidade de, durante a lecionação desta UC, o estudante poder desenvolver um conjunto de leituras que torne a redação de parte do seu relatório mais consistente, com o intuito de potenciar uma reflexão ponderada e em articulação com o estudo do caso/tema prático que vier a escolher. É sobretudo aqui que o quadro concetual e teórico da Educação Histórica ganha espaço e consistência, para um futuro desenvolvimento, num processo de investigação-ação no Relatório Final. Este Relatório tem um ou mais orientadores e engloba uma componente teórica em função do tema escolhido e uma componente prática com recolha de elementos na Escola onde realizou a iniciação à prática profissional. 


\section{CONSTRUINDO UM QUADRO EPISTEMOLÓGICO CONSISTENTE E REFLEXIVO}

Entre 2017 e 2019 foram defendidos na Faculdade de Letras do Porto mais de 40 Relatórios do Mestrado em Ensino de História, a maioria dos quais hoje disponível na Biblioteca Digital da FLUP ${ }^{11}$. A sua construção e orientação passou essencialmente por quatro vetores considerados essenciais: um quadro teórico que permitisse aos seus autores não apenas colocarem em prática os conteúdos abordados nas UC de Investigação Educacional e Perspetivas em Educação Histórica mas, sobretudo, visitarem os diferentes estudos, artigos, livros, comunicações... que foram produzidos nos últimos anos no âmbito desse espaço epistemológico; segundo, identificarem, no seu espaço de formação (Escola) e nas suas preocupações ou motivações científicas, um objeto de estudo que teriam de testar no laboratório onde estavam a realizar a sua prática profissional; terceiro, explicarem as metodologias e técnicas de investigação utilizadas, bem como os resultados que obtiveram, cruzando-os com os objetivos/hipóteses de partida; quarto, e talvez o aspeto mais importante, os contributos que esse trabalho trouxe para densificar a sua reflexividade profissional. Sobretudo este último aspeto é muito importante, até para discussão com um júri normalmente formado com investigadores com mais experiência (por exemplo com doutoramentos na área de Educação Histórica ou Supervisão Pedagógica), evidenciando a maturidade de uma reflexão que deve ser contínua e sempre numa perspetiva de docente como investigador social. Para além deste aspeto, a assistência aos estudos de casos investigados e apresentados relativos a outras Escolas por outros colegas permite ainda, mesmo em formação inicial, o mestre partir para a sua profissionalidade com uma bagagem experiencial muito rica, diversificada, mas, espera-se, também muito fluida e flexível, ao constatar a singularidade de todos os casos, embora podendo sempre abordá-los com perspetivas já testadas noutros contextos. Para além disso, a sua própria experiência investigativa permite-lhe abandonar o senso comum empírico e sincrético e dar-lhe confiança científica para o encarar com um sentido mais rigoroso e criterioso.

Uma pequena viagem pelos principais temas e conclusões mostra-nos também as preocupações essenciais de um estudante em iniciação profissional, tanto derivadas das lacunas da formação anterior como de fantasmas que povoam as «ideias feitas» sobre as nossas escolas e alunos do ensino básico e secundário, ou ainda de motivações ou dúvidas muito pessoais sobre a didática da disciplina.

Por exemplo, selecionar a imagem, seja fixa através da fotografia ou do objeto artístico, seja em movimento de um documentário, filme ou videograma, como objeto de investigação tem constituído um dos temas quantitativamente mais significativo. As conclusões apontam invariavelmente para a constatação de poder constituir-se como

\footnotetext{
${ }^{11}$ A lista dos mais significativos disponíveis na Biblioteca Digital da FLUP encontra-se em anexo a este ensaio.
} 
um elemento essencial da didática, tanto como motivação como recurso ou até incorporado no processo de avaliação. Os resultados menos positivos que têm sido obtidos derivam muito mais da (in)capacidade de exploração ou (in)adequação do seu uso, face às ideias previamente concebidas para a sua utilização. Também essas experiências se tornam úteis para uma outra utilização posterior. A História Local tem também sido um objeto de estudo muito pretendido, não apenas porque facilita a inserção do futuro professor no sentido histórico da localidade, como permite ainda trazer para dentro da sala de aula algo mais próximo da vivência dos alunos, surgindo inclusivamente exemplos de incorporação de testemunhos transgeracionais pela riqueza informativa que pais, avós ou outras personalidades de outras gerações podem trazer e aos quais os alunos dão elevada confiança e credibilidade como fonte histórica. A História do Presente e as suas múltiplas fontes, sobretudo no $9 .^{\circ}$ e no $12 .^{\circ}$ ano, é também uma escolha muito selecionada nas preocupações dos futuros mestres. Seja a utilização das redes sociais, seja a preocupação com os Passados Dolorosos dos diferentes países, seja a discutível fiabilidade das notícias, seja a História de minorias ou géneros mais marginalizados, tem havido a preocupação de utilização didática da História numa vertente de função social de que não pode alhear-se. Mas temos também muitos relatórios que visam olhar com um sentido crítico e alternativo para uma didática demasiado estreita (olhando para a importância das inteligências múltiplas), para recursos demasiado presentes e a necessitarem de alternativas (analisando criticamente a omnipresença dos manuais), para a importância da origem sociofamiliar dos alunos, ou ainda para a importância da inclusão da caricatura, do humor ou da empatia como recursos ou processos de cativar para a disciplina e para a importância de alguns conteúdos, recursos ou posturas perante o passado.

Estas opções vão em linha com CERRI ${ }^{12}$ quando afirma:

A história oferece a ideia que todos os pontos de vista sobre um determinado assunto são relativos a determinadas origens, sujeitos, tempos [...]. A história permite compreender que todas as coisas estão sempre vinculadas a contextos, e só são compreendidas se os contextos em que surgem e se desenvolvem são esmiuçados. Por isso são relativas, por relacionarem-se a contextos, condições, pessoas, posicionamentos. [...] Por essa razão há quem diga que, no ensino de história, o mais importante não é estudar os conteúdos em si, mas o método, a forma de pensar, produzir e criticar o saber sobre os seres humanos no tempo ${ }^{13}$.

\footnotetext{
${ }^{12}$ CERRI, 2013.

${ }^{13}$ CERRI, 2013: 65.
} 
Mas, regressando à importância epistemológica do espaço da Educação Histórica, torna-se hoje claro que:

La enseñanza de la historia exige del conocimiento de la disciplina, de su epistemología, que trasladado al vocabulario educativo exige y demanda en los currículos educativos la presencia de contenidos sustantivos o contenidos de primer orden, que intentan responder a las preguntas ¿qué? ¿quién? ¿cuándo? y ¿dónde? Estamos hablando de contenidos que hacen referencia tanto a conocimientos de conceptos o principios, como a fechas y acontecimientos históricos concretos. Pero son igualmente imprescindibles los contenidos estratégicos o de segundo orden. Éstos se definen por la posesión o despliegue de diferentes estrategias, capacidades o competencias para responder a cuestiones históricas y entender de una forma más compleja el pasado. Este último tipo de conocimientos históricos están relacionados con habilidades propias del historiador que se concretan en: la búsqueda, selección y tratamiento de fuentes históricas, la empatía o la perspectiva histórica (BARTON, 2008; LEE, 2005a; VANSLEDRIGHT, 2014; WINEBURG, 2001) ${ }^{14}$.

Torna-se hoje inegável o contributo que a Educação Histórica como espaço científico credibilizado tem trazido para um ensino e aprendizagem da disciplina mais sustentado, justificado e consistente. O caminho desde o último quartel do século XX foi engulhoso, mas investigações académicas sustentadas e pessoas e grupos de investigação em perfeita sintonia e em diferentes espaços trouxeram o quadro concetual, metodológico e epistemológico que não tem cessado de crescer, tanto na formação inicial como contínua de professores de História. Projetos de investigação ou grupos em Unidades de I\&D têm também contribuído para que o edifício criado seja hoje uma referência na cidade multidisciplinar das Ciências Humanas e Sociais.

\section{LEGISLAÇÃO}

PREÂMBULO do DECRETO-LEI 79/2014. «D. R. I Série». 92 (2014-05-14) 2820.

\section{BIBLIOGRAFIA}

ALVES, Luís Alberto Marques (2016) - Epistemologia e Ensino da História. «História Hoje», vol. 5, n. ${ }^{\circ}$, p. 9-30.

ALVES, Luís Alberto Marques; MAIA, Tatyana de Amaral; MIRIAM, Hermeto; RIBEIRO, Cláudia Pinto (2016) - (Re)Construindo o passado: o papel insubstituivel do Ensino da História. Porto Alegre: EdiPUCRS.

BANN, Stephen (1997) - As invenções da história: Ensaios sobre a representação do passado. Rio de Janeiro: Paz e Terra.

\footnotetext{
${ }^{14}$ CARRASCO et al., 2014: 9-10.
} 
BARCA, Isabel, org. (2008) - Estudos de Consciência Histórica na Europa, América, Ásia e África. Actas das 7. as Jornadas Internacionais de Educação Histórica. Braga: CIEd/Universidade do Minho.

(2012) — Ideias Chave para a Educação Histórica: em busca de (inter)identidades. «História Revista», vol. 17, n. ${ }^{\circ} 1$ (jan./jun.), p. 37-51.

BARCA, Isabel; SCHMIDT, Maria Auxiliadora, org. (2009) - Educação Histórica: Investigação em Portugal e no Brasil. Actas das 5. ${ }^{a s}$ Jornadas Internacionais de Educação Histórica. Braga: CIEd/Universidade do Minho.

CARRASCO, Cosme Jesús Gómez; MOLINA, Jorge Ortuño; PUCHE, Sebastián Molina (2014) - Aprender a pensar historicamente. Retos para la historia en siglo XXI. «Tempo e Argumento», vol. 6, n. ${ }^{\circ} 11$ (jan./abr.), p. 05-27.

CERRI, Luis Fernando (2013) - Ensino de história e consciência histórica. Implicações didáticas de uma discussão contemporânea. Rio de Janeiro: FGV.

ESTRELA, Albano; ESTRELA, Maria Teresa (1977) - Perspectivas actuais sobre a formação de professores. Lisboa: Editorial Estampa.

GAGO, Marília (2001) - Concepções dos alunos acerca da variância da narrativa histórica - um estudo com alunos dos anos iniciais do $2 .^{\circ}$ e $3 .^{\circ}$ ciclos do ensino básico. Braga: Universidade do Minho. Dissertação de mestrado.

GRANGER, Christophe, dir. (2013) - À quoi pensent les historiens? Faire de l'histoire au XXI. siècle. Paris: Éditions Autrement.

LAURENTIN, Emmanuel, dir. (2010) - À quoi sert l'Histoire aujourd'hui? Montrouge: Éditions Bayard.

LEVESQUE, Stéphane (2009) - Thinking Historically: Educating Students for the 21. ${ }^{\text {st }}$ Century. Canadá: University of Toronto Press.

Ó, Jorge Ramos (2019) - Fazer a Mão: por uma escrita inventiva na universidade. Lisboa: Edições do Saguão.

PACHECO, Paulo Bernardo de Magalhães (2009) - As Representações dos alunos sobre o ensino e a aprendizagem da História: um estudo com alunos do 9. ${ }^{\circ}$ e $12 .^{\circ}$ anos de escolaridade. Aveiro: Universidade de Aveiro. Dissertação de mestrado.

RÜSEN, Jörn (2008) - Meaning and Representation in History (Making Sense of History). [S.l.]:, Berghahn Books.

(2008) - Time and History: The Variety of Cultures. [S.1.]:, Berghahn Books.

SIMÃO, José Veiga; SANTOS, Sérgio Machado dos; COSTA, António de Almeida (2005) - Ambição para a excelência - a oportunidade de Bolonha. Lisboa: Gradiva.

STEARNS, Peter N.; SEIXAS, Peter; WINEBURG, Sam, ed. (2000) - Knowing, Teaching and Learning History: National and International Perspectives. New York: University Press.

\section{ANEXO (ALGUNS DOS RELATÓRIOS DISPONÍVEIS NA BIBLIOTECA DIGITAL DA FLUP - 2017 A 2019)}

\section{A. 2017}

ALVES, Inês Gomes (2017) - Diários de sala de aula: contributos para o processo de aprendizagem. Porto: [Edição do Autor].

ARAÚJO, Nelson Jorge de Castro (2017) - Os manuais escolares de História: preferências e perspetivas futuras. Porto: [Edição do Autor].

ARAÚJO, Sílvia Isabel Brochado (2017) - Só se ama o que se conhece: contributos da História local no ensino da História. Porto: [Edição do Autor].

CAMPOS, Hugo Miguel Ferreira (2017) - Senta-te e ri! O humor dentro da sala de aula. Porto: [Edição do Autor]. 
CHAMINÉ, Maria Helena Aldinhas (2017) - O ensino da História através das artes. Porto: [Edição do Autor].

FERNANDES, Dina Palmira Amorim (2017) - Conta-me histórias: o que pensam os alunos sobre o bom professor. Porto: [Edição do Autor].

FERREIRA, João Paulo Neves (2017) - Heróis acidentais: o papel dos indivíduos singulares na História. Porto: [Edição do Autor].

MONTEIRO, Tamara Bianca Pereira (2017) - História Go: o contributo dos dispositivos móveis para o ensino-aprendizagem nas visitas de estudo. Porto: [Edição do Autor].

\section{B. 2018}

CARDOSO, Joana Filipa Alves (2018) - O cinema na aula de História: a ficção como recurso. Porto: [Edição do Autor].

COSTA, Marco António da Silva (2018) - PensARTE e educARTE: contributo da Arte no desenvolvimento da sensibilidade estética na disciplina de História. Porto: [Edição do Autor].

DAMÁSIO, António Magalhães (2018) - A flexibilidade curricular: história da cultura e das artes, um caso de estudo. Porto: [Edição do Autor].

DUARTE, Duarte Nuno Monteiro (2018) - O ensino da História para o século XXI: uma perspetiva sustentada na teoria das Inteligências Múltiplas. Porto: [Edição do Autor].

FAUSTINO, Hugo Alexandre Rosa (2018) - Recriação histórica e didática. Porto: [Edição do Autor].

FERNANDES, Diana Isabel Caldas (2018) - A participação dos alunos no programa parlamento dos jovens. Porto: [Edição do Autor].

FREITAS, Juliana Marlene Nogueira (2018) - Lembrar Guimarães: A história Local e o seu património imaterial no ensino da História. Porto: [Edição do Autor].

MOURA, Bruno André Pinto (2018) - Contributos para uma prática avaliativa diferenciada em História no ensino secundário. Porto: [Edição do Autor].

OLIVEIRA, Ana Patrícia da Silva (2018) - A aula invertida em História: a perceção dos alunos. Porto: [Edição do Autor].

PINTO, Marta Afonso (2018) - Guerra Colonial: O olhar do jovem estudante português. Porto: [Edição do Autor].

SILVA, Alexandra Filipa Guedes da (2018) - Ver e refletir sobre a alimentação nos programas de História. Porto: [Edição do Autor].

SILVA, Bruna Alexandra Pinto (2018) - Oh stôra, isso conta para a nota? Contributo para uma avaliação de sucesso na disciplina de História. Porto: [Edição do Autor].

SILVA, Mariana Ventura de Matos (2018) - A empatia como estratégia para o ensino-aprendizagem em História. Porto: [Edição do Autor].

VIEIRA, Andreia Patrícia de Lima (2018) - História é como os números, quando começamos nunca mais acabamos: A perceção dos alunos sobre a disciplina de História A. Porto: [Edição do Autor].

\section{2019}

CARDOSO, Daniela Marisa Sousa (2019) - Olha o passarinho! Ensinar a História através da fotografia. Porto: [Edição do Autor].

COSTA, José Emanuel Pinheiro Mendonça da (2019) - @Fator_História: uma perspetiva sobre o uso das redes sociais no ensino. Porto: [Edição do Autor].

COSTA, Pedro Miguel Mota (2019) - A Caixa-forte do Ensino: Aprender Divertida(mente). Porto: [Edição do Autor]. 
CUNHA, Mário Raul de Sousa (2019) - Arte e objeto artístico na Didática da História. Porto: [Edição do Autor].

FERNANDES, Joana Luzia Pires (2019) - O visível e o invisível, detalhes que gritam! A fotografia como vestígio do real fragmentado para o ensino da História. Porto: [Edição do Autor].

FONSECA, Fábio Fernando Alves (2019) - Uns são filhos de médicos: a importância do background sociofamiliar para os alunos. Porto: [Edição do Autor].

LEAL, Nuno Miguel Babo (2019) - A História é o passado, o presente e o futuro: a perceção de alunos e professores sobre o ensino da História. Porto: [Edição do Autor].

MARTINS, Diana Raquel da Costa (2019) - Madrinha e Soldados: remetente: presente. destinatário: passado. Porto: [Edição do Autor].

MENDES, Nuno Miguel Soares (2019) - A Flexibilização Curricular no Ensino da História: Turmas de Currículo Adaptado, no $3 .^{\circ}$ Ciclo do Ensino Básico. Porto: [Edição do Autor].

PINTO, Frederico André Neves Vitó Bargueño (2019) - Sentimos que não somos ouvidos: a importância da relação professor-aluno. Porto: [Edição do Autor].

PINTO, Vítor Manuel Inácio (2019) - A Blogosfera no Ensino da História: da epistemologia à práxis. Porto: [Edição do Autor].

SEIXO, José Alberto Marinheiro do (2019) — Ó 'stor, isso são fake news: a literacia mediática e a construção do conhecimento histórico através de textos jornalísticos. Porto: [Edição do Autor].

VALE, Filipe Alberto Vieira do (2019) - A visita de estudo na Didática da História. Porto: [Edição do Autor]. 


\title{
PRIMEIRO ESTRANHA-SE, DEPOIS ENTRANHA-SE. ALGUNS OLHARES SOBRE APROPRIAÇÕES DA EDUCAÇÃO HISTÓRICA EM RELATÓRIOS DE FORMAÇÃO INICIAL
}

\author{
RAQUEL PEREIRA HENRIQUES*
}

\begin{abstract}
Resumo: Há um olhar inicial e muito genérico para a organização da formação inicial de professores de História em Portugal, entre 1930-2020, analisando continuidades, interrupções, tendências. Num segundo momento, um outro ol har parte dos relatórios da prática de ensino supervisionada produzidos na Faculdade de Ciências Sociais e Humanas da Universidade Nova de Lisboa, a partir de 2007. Aprofundando a observação, vamos percecionando então a influência crescente das investigações de Isabel Barca e a educação histórica vai surgindo em mais trabalhos feitos nas escolas e apresentados na universidade. Se é certo que foi a aula-oficina que se transformou na porta de entrada para as leituras que utilizam, a consciência histórica passou depois a fazer parte das preocupações de muitos destes formandos.
\end{abstract}

Palavras-chave: Formação inicial de professores; Mestrados em ensino; Consciência histórica.

Abstract: The first section of the present study offers a general overview on pre-service teacher training of History in Portugal between 1930-2020, focussing on its historical continuity, interruptions and trends. The second section of this article analyses supervised teaching practice reports carried out at the NOVA School of Social Sciences and Humanities (Faculdade de Ciências Sociais e Humanas da Universidade Nova de Lisboa) from 2007 onwards. An in-depth observation of these reports shows a growing influence of Isabel Barca's research. Moreover, the topic of historical education is recurrent in work carried out in schools and then presented at the above-mentioned university. Although the workshop classroom can be considered the starting point for pre-service teachers' adopted readings, many of these pre-service teachers developed a considerable interest in historical awareness.

Keywords: Pre-service teacher training; Master of Arts in Teaching; Historical awareness.

\section{FORMAÇÃO INICIAL DE PROFESSORES. 1930-2020, OLHARES TRANSVERSAIS}

Tendo em conta o contexto em que esta obra é publicada, interessou aqui perceber se houve ou não repercussão dos trabalhos de Isabel Barca na formação inicial de professores do $3 .^{\circ}$ ciclo do ensino básico e ensino secundário em Portugal. Para isso partiu-se de dois tipos de fontes:

\footnotetext{
* Faculdade de Ciências Sociais e Humanas (FCSH) da UNL/Instituto de História Contemporânea (IHC). E-mail: raquel.henriques@fcsh.unl.pt.
} 
a) A legislação mais relevante publicada sobre formação inicial de professores entre 1930 e 2014;

b) Os relatórios de estágio ou da "prática de ensino supervisionada» produzidos por formandos da formação inicial de professores de História e de Geografia e, mais tarde, de professores de História, entre os anos de 2010 e 2019, na Faculdade de Ciências Sociais e Humanas da Universidade Nova de Lisboa.

A formação inicial de professores foi, de facto, introduzindo algumas novidades ao longo do tempo mas, também, foi retomando características específicas e outras houve que se mantiveram com poucas alterações. Por esse facto, recuamos no tempo para explicar que entre 1930 e 1969 se verificou uma complementaridade entre ensino teórico

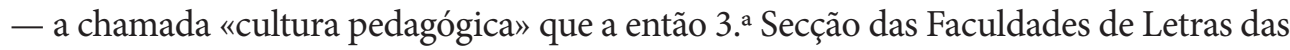
Universidades de Coimbra e de Lisboa assegurava (a Universidade do Porto fê-lo apenas a partir de 1961) - e a "prática pedagógica», que se fazia durante dois anos num Liceu Normal, sob orientação de um professor metodólogo, já efetivo, nomeado pelo reitor e com um tempo mínimo de serviço de cinco anos ${ }^{1}$.

Ser-se admitido na "prática pedagógica» era um processo muito complexo, que implicava seleção documental, sanitária e científica. Esta última fazia-se através de um temido "exame de admissão», constituído por provas escritas e provas orais, públicas, avaliadas por um júri de cinco elementos, entre metodólogos e um catedrático de Ciências Pedagógicas. Com uma aprovação que variava entre os 15\% e os 20\%, os candidatos que tinham dez ou mais valores iniciavam então a prática, o estágio propriamente dito. Este tinha a duração de dois anos e, como os formandos não eram responsáveis por turmas próprias, não eram remunerados. Cumpriam um horário de nove tempos semanais, entre aulas a que assistiam, que lecionavam, entre as atividades que dinamizavam, a participação nas avaliações, as reflexões teórico-práticas que produziam. No final do segundo ano, elaboravam um relatório final do que de mais significativo tivessem feito, numa abordagem simultaneamente descritiva e reflexiva, após o que eram sujeitos ainda a um exame final, o chamado «exame de estado», também constituído por provas escritas e orais.

O modelo de formação inicial de professores manteve-se assim quase inalterável de 1930 a $1969^{2}$ mas, mesmo depois de 1969 , consegue perceber-se que houve ruturas abruptas, que houve igualmente algumas continuidades e que também se retomaram, por vezes, tendências anteriores. A supervisão de o trabalho de estágio ser da responsabilidade de um professor de carreira, com diversos anos de serviço, depois da concordância da direção da escola, foi uma exigência constante. Já os formandos não terem

\footnotetext{
${ }^{1}$ Decreto-Lei 18793. «D. G. I Série». 251 (1930-10-28) 2208-2213.

${ }^{2}$ PINTASSILGO et al., 2010: 49-61.
} 
carga letiva atribuída nem turmas da sua própria responsabilidade, justificando assim a não remuneração, foi uma situação que se prolongou por um longo período, que se mantém atualmente e que foi apenas pontualmente interrompida. Tendência que igualmente permaneceu com muito poucas alterações foi a necessidade de produção de trabalhos que aliassem fundamentação teórica e reflexão sobre a componente prática, realizada com os alunos, na escola e para outras turmas e outros professores.

Em 1969, aquela "prática pedagógica» reduziu-se para um ano (situação que permaneceu sem alterações a partir daí), mas os formandos passaram a ter duas turmas próprias, doze horas semanais letivas, a que se acrescentavam as outras nove para o trabalho de estágio propriamente dito, e, consequentemente, eram já remunerados, como resposta a uma antiga reivindicação. Foi anulado o temido «exame de admissão», mas manteve-se o final, o «exame de estado», embora com algumas alterações nas provas exigidas $^{3}$.

Entre 1971 e 1974, outras modificações se verificaram. As Faculdades de Ciências passaram também a oferecer a cultura pedagógica integrada na licenciatura. O estágio continuava a ter a duração de um ano e no final produzia-se uma «monografia científica sobre assunto da matéria fundamental da licenciatura», tal como estava expresso no Decreto 443/71. A preocupação era, mais uma vez, a conjugação entre a teoria e a prática docente. Esta formação integrada alargou-se, em 1978, às Universidades do Minho e de Aveiro, ao Instituto Universitário dos Açores e, em 1988, às Faculdades de Letras.

Até 1978, coexistiram dois modelos de formação inicial de professores — o das Faculdades de Letras, já analisado, e o chamado Ramo de Formação Educacional das Faculdades de Ciências, que dispensava já o «exame de estado», situação que gerava indignação e apelos à uniformidade por parte dos candidatos das Faculdades de Letras.

Em 1979, as Escolas Superiores de Educação estavam habilitadas a formar professores para os primeiros seis anos de escolaridade, ou seja, para o então ensino básico, enquanto as Faculdades de Letras e de Ciências continuavam a formar profissionais para os então cursos gerais e cursos complementares dos liceus ${ }^{4}$.

Por outro lado, a formação em exercício tinha sido organizada para quem não era profissionalizado e, em 1979, o Decreto-Lei 519-T1/79 especificava que teria a duração de dois anos, a partir de um Plano Individual de Trabalho (PIT) que, mais uma vez, deveria conjugar formação académica com a experiência prática, devendo ser supervisionada por um orientador pedagógico. O Despacho 358 de 1980 esclareceu alguns aspetos práticos, mas essa profissionalização em exercício acabou por ser substituída em 1985 pela formação em serviço, também com a duração de dois anos, visando

\footnotetext{
${ }^{3}$ Ver Decreto-Lei 48868. «D. G. I Série». 40 (1969-02-17) 160-162.

${ }^{4}$ Decreto-Lei n. ${ }^{\circ}$ 513-T/79. «D. R. 3. ${ }^{\circ}$ Suplemento, I Série». 296 (1979-12-26) 3350-(60) a 3350-(64).
} 
igualmente garantir a ligação entre as componentes mais teóricas das Ciências da Educação e a prática letiva, que se efetivava nas escolas ${ }^{5}$.

Em 1988, as universidades reorganizaram o Ramo de Formação Educacional: um ano de pós-graduação nas Faculdades de Letras e de Ciências Sociais e Humanas e um ano de estágio, numa escola. Um seminário pedagógico no segundo ano tentava, de novo, que se produzissem trabalhos que articulassem a teoria e a prática.

De 1988 até 2007, altura em que foram criados os segundos ciclos de Bolonha e, por conseguinte, os mestrados em ensino, a formação inicial manteve-se naquele último modelo e os formandos tinham duas turmas próprias e eram remunerados. O Decreto-Lei 43/2007 aprovou então o novo regime jurídico da habilitação profissional para a docência e ressurgiu o modelo dos estagiários sem turmas atribuídas e, consequentemente, sem remuneração, situação que se mantém na atualidade.

Diluiu-se também a formação científica e prática dos futuros professores de História e de Geografia, com o aparecimento do mestrado intitulado Ensino de História e de Geografia no 3. ${ }^{\circ}$ Ciclo do Ensino Básico e no Ensino Secundário, fundindo as duas áreas de formação. Mas todos estes mestrados em ensino passaram então a exigir a defesa pública de um trabalho académico, um relatório de estágio que, a partir de um tema previamente definido, reunisse uma reflexão teórica e apresentasse de que forma a temática tinha sido desenvolvida na escola.

Em 2014, o Decreto-Lei 79/2014 separou de novo a formação inicial dos professores de História da formação inicial dos professores de Geografia para o $3 .^{\circ}$ ciclo do ensino básico e ensino secundário, aumentou o número de créditos exigidos para ingresso no ciclo de estudos, aumentou o número de horas para as didáticas específicas e manteve o trabalho final, o relatório de estágio ou «relatório da prática de ensino supervisionada», com uma componente teórica e outra prática, defendido igualmente em provas públicas e que permite concluir a habilitação profissional para a docência.

Será, portanto, sobre estes últimos treze anos, desde a criação dos mestrados em ensino em 2007 e desde a exigência da produção e defesa de um relatório final apresentado em provas públicas, que esta reflexão se vai debruçar. De que modo se pode percecionar a influência de Isabel Barca em prol da educação histórica nos trabalhos teóricos e práticos dos formandos da Faculdade de Ciências Sociais e Humanas da Universidade Nova de Lisboa, se se percebe ou não essa influência e de que modo foram algumas questões que nortearam esta análise.

\footnotetext{
${ }^{5}$ Ver Decreto-Lei 580/80 e Decreto-Lei 581/80. «D. R. 2. ${ }^{\circ}$ Suplemento, I Série». 301 (1980-12-31).
} 


\section{OS RELATÓRIOS}

A partir de 2007, há registos oficiais dos relatórios da prática de ensino supervisionada em todas as instituições universitárias que decidiram oferecer a formação inicial de professores para o $3 .^{\circ}$ ciclo do ensino básico e ensino secundário. Por ser integrada nos segundos ciclos de formação, aqueles relatórios ficam nos repositórios científicos de acesso aberto.

A Faculdade de Ciências Sociais e Humanas interrompeu essa formação a partir de setembro de 2004, tendo possibilitado a conclusão do então chamado Ramo de Formação Educacional a quem estava inscrito no anterior modelo, já descrito, ao longo de 2005 e 2006. Só em 2008-2009 retomou a formação inicial de professores de História e de Geografia, tendo em conta o modelo conjunto, definido no Decreto-Lei 43/2007, e acompanharia então a prática nas escolas, que se iniciou no ano letivo seguinte, de 2009-2010.

O primeiro relatório defendido nestes novos moldes data, assim, de 2010 e intitula-se O construtivismo no ensino da História e da Geografia - o professor como mediador no processo de ensino/aprendizagem. Há trinta relatórios de estágio ou da prática de ensino supervisionada (como passou a chamar-se) do mestrado em ensino de História e de Geografia no $3 .^{\circ}$ ciclo do ensino básico e no ensino secundário e o último foi defendido em 2016.

Por outro lado, os relatórios da prática de ensino supervisionada que correspondem à última reorganização da formação inicial de professores, que ocorreu com a publicação do Decreto-Lei 79/2014 e que de novo separou a formação inicial dos professores de História, começaram a ser defendidos em 2017. Foi perfeitamente por acaso que o último que foi objeto de análise, defendido em provas públicas que ocorreram em finais de dezembro de 2019, se intitulou A construção dos conhecimentos em História, fazendo assim lembrar o primeiro do anterior modelo. Ou seja, do mestrado em ensino de História no $3 .^{\circ}$ ciclo do ensino básico e no ensino secundário conseguimos reunir dezoito relatórios concluídos entre 2017 e 2019, tendo sido propositadamente excluídos outros quinze, por ainda se encontrarem em elaboração.

Assim sendo, centrei-me em quarenta e oito relatórios da prática de ensino supervisionada, trinta de História e de Geografia e dezoito de História. As temáticas destes trabalhos finais são muito variadas e dão-se alguns exemplos: a utilização do jogo e/ou do videojogo, o ensino através da música, do cinema, da iconografia, o trabalho de grupo, a indisciplina, a exploração de recursos digitais, de portefólios, do património local, as oficinas pedagógicas, os debates promovidos, a autorregulação da aprendizagem, a aula-oficina, a avaliação, a promoção da educação intercultural, o desenvolvimento do projeto educativo e do trabalho de projeto. 


\section{E A EDUCAÇÃO HISTÓRICA?}

Até 2017 houve cinco relatórios que utilizaram obras de Isabel Barca, sobretudo os que de alguma forma se debruçaram sobre a aula-oficina, o construtivismo, o trabalho de investigação, o envolvimento do aluno nesse trabalho. Nenhum deles utiliza, no entanto, a expressão «educação histórica», ou seja, citam obras de Isabel Barca mas não refletem sobre as questões da educação histórica propriamente dita e não há uma apropriação do conceito. Essa característica é aliás visível num ou noutro subtítulo desses trabalhos em que se referem especificamente os «objetivos da educação histórica» mas cujo conteúdo se refere à totalidade do trabalho realizado nas aulas de História, sem uma especificidade que correlacionasse a prática com o desenvolvimento de um pensamento histórico e com a reflexão sobre esse pensamento ${ }^{6}$.

Podemos, aliás, dizer que foi a aula-oficina que despertou maior interesse nesses formandos de História e de Geografia, levando alguns a experimentar aplicá-la em conjuntos de aulas, em unidades temáticas, que planificaram e lecionaram. Foi a aula-oficina que se transformou na porta de entrada para as leituras dos trabalhos de Isabel Barca ${ }^{7}$, explicando-se assim que alguns deles tivessem igualmente pesquisado o que Maria Auxiliadora Schmidt ou Marília Gago haviam produzido, mas de forma ainda muito tímida, se é que se pode aplicar este termo para uma ou outra referência, apenas esporádica.

O envolvimento com a educação histórica, com a construção do pensamento histórico, com o facto de se pretender «suscitar uma reflexão instigante por parte dos jovens sobre mudanças e continuidades» ${ }^{8}$, sobre a problematização da relação passado -presente é, sobretudo, mais evidente a partir de 2017, nos relatórios do mestrado em ensino de História. Neles surgem de forma mais recorrente Isabel Barca mas, também, de forma muito significativa, autores como Peter Lee, Jörn Rüsen, Maria Auxiliadora Schmidt, para além de Olga Magalhães, Marília Gago, Helena Pinto, Regina Parente, Júlia Castro, Mariana Lagarto.

Denota-se um envolvimento maior com estas leituras, uma clara utilização das mesmas, uma procura de aplicação prática de propostas concretas e de análise dos resultados. Pensar sobre a "educação e a consciência histórica» ${ }^{9}$ passou a fazer parte das preocupações de muitos destes formandos. Percebe-se pelos seus trabalhos que começou a fazer-se uma reflexão sobre a disciplina de História e, sobretudo, denota-se uma preocupação evidente sobre como debater alguns temas da atualidade, sobre como trabalhar diversas fontes materiais e imateriais com os alunos, sobre como cruzar essas fontes, por vezes com perspetivas divergentes, sobre como envolver os alunos com o património e a história locais ou com pequenos objetos, em trabalhos de projeto e, também,

\footnotetext{
${ }^{6}$ MARTINS, 2019: 55-58.

${ }^{7}$ BARCA, org., 2004: 131-141.

${ }^{8}$ BARCA, 2018: 51.

${ }^{9}$ BARCA, 2011.
} 
como trabalhar com esses alunos em díades ou em pequeno grupo, como partir das suas conceções prévias e/ou das suas narrativas com um objetivo cada vez mais claro, o de "procurar construir conhecimento histórico válido e significativo para cada sujeito» ${ }^{10}$.

$\mathrm{O}$ que se denota é que essa preocupação tem aumentado de forma progressiva e surge cada vez mais evidente nos trabalhos teóricos e práticos de quem está a concluir a formação inicial de professores de História. Esse facto é ainda mais notório em alguns dos trabalhos que estão em elaboração e que, pelo facto, não foram aqui objeto de análise: a título de exemplo, um deles intitula-se $A$ explicação causal no contexto da Educação Histórica, outro debruça-se sobre a Avaliação formativa numa abordagem de diferenciação pedagógica, ou ainda um outro intitulado A disciplina de História: o que estarão os alunos a aprender sobre o passado? Estas são algumas das mais recentes propostas, que denotam preocupações nítidas em trabalhar as fontes de forma a serem questionadas pelos alunos ou de levar estes últimos a refletir sobre a sua validade, as intenções dos seus autores, sobre como selecionar fontes e como questionar o trabalho do historiador, bem como os contributos do património ou da história local para o desenvolvimento da consciência histórica. Por outro lado, reflete-se sobre várias perspetivas de trabalho construtivo, colaborativo, sobre o trabalho que se pode fazer em aula, fora dela, e sobre a forma como esse trabalho pode ser produzido $^{11}$. O caminho tem vindo a construir-se, isso parece claro.

Podemos, portanto, concluir que se em 2010 as referências à autora Isabel Barca e às suas propostas e reflexões eram ainda escassas, elas foram aumentando progressivamente e agora, em 2020, são já muito evidentes. Se esta análise fosse feita no próximo ano, poder-se-ia afirmar que a educação histórica e os seus pressupostos integrariam mais de metade dos trabalhos finais produzidos no âmbito da formação inicial de professores, ou seja, das apostas para a chamada componente não letiva do mestrado em ensino de História, o que atesta bem da vitalidade daqueles estudos e daquelas propostas, que parecem responder às necessidades sentidas pelos formandos.

\section{AMANHÃ}

É claro que falta aqui perceber se estes futuros docentes, depois de estarem no terreno, continuarão, ou não, com estas preocupações. Que perspetivas de trabalho manterão ou nortearão as suas atividades? Será que farão do seu dia a dia uma construção pessoal, feita com os alunos, a pensar neles? Essa é uma interrogação que persiste e inquieta. Proteger-se-ão, preservando métodos e recursos, não envolvendo os alunos no processo, não contando com o conhecimento que estes trazem para a escola? Ou, pelo contrário, integrarão esses saberes?

\footnotetext{
${ }^{10}$ BARCA, 2008: 6.

${ }^{11}$ SCHMIDT \& NECHI, org., 2016.
} 
O caminho é incerto, tem sido difícil para uns, mais do que para outros, questão que está também muito dependente da organização da escola em que se integram, análise que François Dubet tem vindo a fazer de forma bastante pertinente ${ }^{12}$. Daí a relevância que continua a assumir a formação contínua, podendo ser muito útil para ajudar a refletir sobre estas e outras questões e, também, sobre como contornar algumas dificuldades com as quais todos nos deparamos, sobretudo no que diz respeito à resistência à mudança, às perturbações que essa mudança acarreta e às alterações que são introduzidas nas práticas e, igualmente e necessariamente, nas formas de avaliação.

\section{FONTES}

DECRETO n. ${ }^{\circ}$ 18793. «D. G. I Série». 251 (1930-10-28) 2208-2213. Cria a secção de ciências pedagógicas

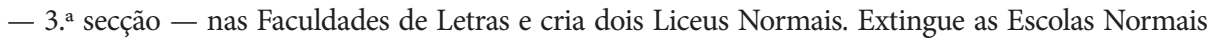
Superiores.

DECRETO-LEI n. ${ }^{\circ}$ 48868. «D. G. I Série». 40 (1969-02-17) 160-162. Regulamenta a formação pedagógica de professores do ensino liceal e do ensino técnico e profissional.

DECRETO-LEI n. ${ }^{\circ}$ 513-T/79. «D. R. 3. . Suplemento, I Série». 296 (1979-12-26) 3350-(60) a 3350-(64). Define a rede de estabelecimentos do ensino superior politécnico. As Escolas Superiores de Educação ficam responsáveis pela formação dos professores para o ensino básico.

DECRETO-LEI n. ${ }^{\circ}$ 519-T1/79. «D. R. 7. o Suplemento, I Série». 299 (1979-12-29) 3446-(129) a 3446-(138). Estabelece o regime de contratos dos docentes e também o regime da Profissionalização em Exercício. Define as componentes do Plano de Trabalho Individual.

DECRETO-LEI n. ${ }^{\circ}$ 580/80. «D. R. 2. ${ }^{\circ}$ Suplemento, I Série». 301 (1980-12-31) 4244-(27) a 4244-(37). Estabelece normas relativas à docência nos ensinos preparatório e secundário.

DECRETO-LEI n. ${ }^{\circ}$ 581/80. «D. R. 2. ${ }^{\circ}$ Suplemento, I Série». 301 (1980-12-31) 4244-(37) a 4244-(44). Estabelece normas relativas à colocação dos professores profissionalizados não efetivos e provisórios dos ensinos preparatório e secundário.

DECRETO-LEI n. ${ }^{\circ}$ 43/2007. «D. R. I Série». 38 (2007-02-22) 1320-1328. Aprova o regime jurídico da habilitação profissional para a docência na educação pré-escolar e nos ensinos básico e secundário.

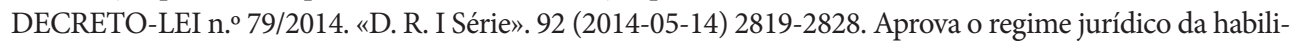
tação profissional para a docência na educação pré-escolar e nos ensinos básico e secundário.

DESPACHO n. ${ }^{\circ}$ 358/80. «D. R. II Série». 253 (1980-10-31) 7032-7036. Aprova o projeto global de formação dos docentes das escolas preparatórias e secundárias.

FCSH/UNL - Relatórios de Estágio para cumprimento dos requisitos necessários à obtenção do grau de mestre em ensino de História e de Geografia no 3. ${ }^{\circ}$ ciclo do Ensino Básico e no Ensino Secundário.

${ }^{12}$ DUBET, 2002; DUBET, 2004. 


\section{BIBLIOGRAFIA}

BARCA, Isabel, org. (2004) - Para uma Educação Histórica com Qualidade: Actas das IV Jornadas Internacionais de Educação Histórica. Braga: CIEd/Universidade do Minho; Instituto de Educação e Psicologia/Universidade do Minho, p. 131-144.

(2008) - Estudos de Consciência Histórica na Europa, América, Ásia e África. Actas das 7. as Jornadas Internacionais de Educação Histórica. Braga: CIEd/Universidade do Minho.

(2011) - Educação e Consciência Histórica na Era da Globalização. Braga: CIEd/Universidade do Minho; Lisboa: Associação de Professores de História.

(2018) - Pensar a mudança em História: debater e aprender. In URBAN, Ana Claudia; MARTINS, Estevão C. de Rezende; CAINELLI, Marlene, org. - Educação Histórica. Ousadia e Inovação em Educação e em História. Escritos em homenagem a Maria Auxiliadora Moreira dos Santos Schmidt. Curitiba: W. A. Editores, p. 47-61.

DUBET, François (2002) - Le déclin de l'institution. Paris: Éditions du Seuil. (2004) - Lécole des chances. Qu'est-ce qu’une école juste? Paris: Éditions du Seuil et La République des Idées.

MARTINS, Estevão C. de Rezende (2019) - Consciência Histórica. In FERREIRA, Marieta de Moraes; OLIVEIRA; Margarida Maria Dias de, coord. — Dicionário de Ensino de História. Rio de Janeiro: FGV Editora, p. 55-58.

PINTASSILGO, Joaquim; MOGARRO, Maria João; HENRIQUES, Raquel Pereira (2010) - A formação de professores em Portugal. Lisboa: Edições Colibri.

SCHMIDT, Maria Auxiliadora; NECHI, Lucas Pydd, org. (2016) - Brazilian investigation in history education. Curitiba: W. A. Editores. 



\title{
A EDUCAÇÃO HISTÓRICA EM PORTUGAL: PERCURSOS FORMATIVOS E INVESTIGATIVOS NA UNIVERSIDADE DO MINHO*
}

\author{
GLÓRIA SOLÉ**
}

\begin{abstract}
Resumo: Este texto visa apresentar uma síntese histórica, embora não exaustiva, da génese e consolidação da Educação Histórica na Universidade do Minho, área que se tem vindo a afirmar há mais de três décadas. Começa-se por destacar o pioneirismo da Educação Histórica na Universidade do Minho na década dos anos 90 do século passado e a influência anglo-saxónica na investigação e no ensino de História em Portugal. Procede-se a uma análise da produção académica na área da Educação Histórica na Universidade do Minho, realizada ao longo deste período em dissertações de mestrado, teses de doutoramento e pós-doutoramento, incorporam-se também os relatórios de estágio que relacionam a teoria com a prática pedagógica, reforça-se também o papel das Jornadas de Educação Histórica, que vão já na sua XX edição e que consolidam a nível internacional a Educação Histórica e o reconhecimento científico da investigação académica portuguesa nesta área.
\end{abstract}

Palavras-chave: Educação Histórica; História da Educação Histórica na UM; Teoria e prática; Epistemologia.

Abstract: This text aims to present a historical synthesis, although not exhaustive, of the genesis and consolidation of Historical Education at the University of Minho, an area that has been affirming itself for more than three decades. We begin by highlighting the pioneerism of Historical Education at the University of Minho in the decade of the 90s of the last century and the Anglo-Saxon influence in the investigation and teaching of History in Portugal. An analysis of academic production in the area of History Education at the University of Minho, carried out throughout this period in master's dissertations, doctoral and post-doctoral theses, also includes the internship reports that relate the theory with pedagogical practice that also reinforces the role of Jornadas de Educação Histórica, which are already in their 20th edition and which consolidate History Education at international level and the scientific recognition of Portuguese academic research in this area.

Keywords: History Education; UM history of History Education; Theory and practice; Epistemology.

\section{INTRODUÇÃO}

Este texto visa apresentar uma síntese histórica, embora não exaustiva, da génese e consolidação da Educação Histórica na Universidade do Minho, área que se tem vindo a afirmar há mais de três décadas em Portugal, tendo sido esta universidade a primeira a implementar e difundir os princípios epistemológicos da Educação Histórica no nosso país. Sobre a investigação em Educação Histórica e as implicações da investigação no

\footnotetext{
* Este trabalho é financiado pelo CIEd - Centro de Investigação em Educação, projetos UID/CED/1661/2013 e UID/CED/1661/2016, Instituto de Educação, Universidade do Minho, através de fundos nacionais da FCT/MCTES-PT.

** CIEd/U.Minho. E-mail: gsole@ie.uminho.pt.
} 
ensino em Portugal foram já publicados alguns artigos que permitem construir a história da Educação Histórica em Portugal ${ }^{1}$.

Em Portugal, o pioneirismo da Educação Histórica surge na Universidade do Minho, para tal, contribuíram principalmente no início da década de 90 as investigações realizadas pelas Professoras Isabel Barca e Maria do Céu Melo, à data docentes do Instituto de Educação e Psicologia da Universidade do Minho, que realizaram o doutoramento no Institute of Education de Londres (Inglaterra), sob orientação do Professor Peter Lee, mas também a Professora Luísa Varela de Freitas, Professora do Instituto de Estudos da Criança, com Doutoramento realizado na Universidade de Iowa, nos EUA, também nesta área, mas orientado para os primeiros anos de escolaridade.

Neste processo de afirmação, mas principalmente de disseminação dos fundamentos e princípios epistemológicos da Educação Histórica, é de realçar o contributo das Jornadas Internacionais de Educação Histórica, realizadas desde 2001, estando já na sua XX edição. As primeiras Jornadas de Educação Histórica tiveram como objetivo principal inicialmente «dar a conhecer uma linha inovadora e desafiante para quem gosta de ensinar (e aprender) História» ${ }^{2}$ e à medida que se ia consolidando a investigação nesta área, procuraram mostrar a linha de pesquisa em Educação Histórica que se vinha desenvolvendo no âmbito dos mestrados académicos e doutoramentos realizados na Universidade do Minho. Nas primeiras edições das Jornadas, foram apresentados também alguns estudos de autores destacados no plano internacional (Reino Unido e Estados Unidos) bem como os resultados das primeiras investigações no país. A internacionalização inicia-se com as $\mathrm{V}$ Jornadas Internacionais de Educação Histórica, nomeadamente com a cooperação do grupo de investigação da Universidade Federal do Paraná, liderada pela Prof. ${ }^{a}$ M. Auxiliadora Schmidt ${ }^{3}$. A partir de 2007, as Jornadas têm contado com a participação de investigadores da Europa, América (do Norte e do Sul) e Países Lusófonos, tendo alcançado o estatuto de Congresso. Desde 2005, as Jornadas Internacionais, para além de Portugal (Universidade do Minho e FLUP) e Brasil (Curitiba, Londrina, Goiás e Mato Grosso), realizaram-se na Espanha (Barcelona em 2013 e Múrcia em 2018) e em 2019 na Colômbia (Bogotá).

Esta internacionalização e consolidação da área da Educação Histórica em Portugal foi fruto de um trabalho concertado de investigadores, professores e alunos de graduação e pós-graduação, que com as suas investigações e experiências pedagógicas difundiram os resultados em termos científicos e pedagógicos do ensino e aprendizagem da História e contribuíram para a mudança do ensino da História em Portugal.

Para uma melhor estruturação da síntese sobre a Educação Histórica, e em particular, a sua relação com a Universidade do Minho, organizou-se o presente texto em

\footnotetext{
${ }^{1}$ BARCA, 2009; BARCA \& ALVES, 2016; MELO, 2015; SOLÉ, 2017a; SOLÉ, 2017b; SOLÉ, 2019.

${ }^{2}$ BARCA \& ALVES, 2016: 7.

${ }^{3}$ BARCA \& ALVES, 2016.
} 
duas secções: 1) Formação de Professores na Universidade do Minho e o ensino de História; 2) A pós-graduação em Educação Histórica.

\section{FORMAÇÃO DE PROFESSORES DE HISTÓRIA NA UNIVERSIDADE DO MINHO E O ENSINO DE HISTÓRIA}

Começaremos com uma breve contextualização sobre o modelo de ensino de História ministrado na Universidade do Minho nas últimas três décadas e sua relação com os fundamentos teóricos da Educação Histórica. Há mais de 40 anos que a Universidade do Minho forma professores de História, e foi das Universidades portuguesas, uma das primeiras a ter o estágio integrado no Curso de História e Ciências Sociais no último ano da sua licenciatura, que era constituída por 4 anos mais o estágio no $5 .^{\circ}$ ano. O curso de História e Ciências Sociais é dos mais antigos da Universidade do Minho, tal como outros na área da formação de professores, a funcionar desde o ano letivo de 1975-76. A formação Científica da área da História e das Ciências Sociais era assegurada pela unidade orgânica do Instituto de Ciências Sociais, por vários Departamentos, e a formação pedagógica e orientação do estágio estava a cargo do Instituto de Educação, à data designado de Instituto de Educação e Psicologia.

Com o tratado de Bolonha (2001), procedeu-se à reorganização dos cursos universitários na União Europeia, tendo adotado ritmos de implementação diferentes nos vários países ${ }^{4}$. Adotou-se um sistema de formação organizado em três ciclos de estudo: 1. ${ }^{\circ}$ Ciclo com a duração mínima de 3 anos - Licenciatura; $2{ }^{\circ}$ Ciclo com a duração de 1 ano e meio a 2 anos - Mestrado; $3 .^{\circ}$ Ciclo - doutoramento com duração variável. Apesar desta unanimidade, a implementação gerou planos curriculares com algumas especificidades nos países subscritores e variações nos planos curriculares das Licenciaturas em História e nos Mestrados de Ensino, mesmo a nível nacional ${ }^{5}$.

Restringir-nos-emos aos dados relativos à Universidade do Minho (UM) neste âmbito, apenas à formação oferecida, entre 2009 e 2020, relativamente ao Mestrado profissionalizante na área para a formação de professores de História. Com o processo de Bolonha, foram extintas as licenciaturas em ensino de 4 ou 5 anos que conferiam habilitação para a docência e foram criados os mestrados em ensino, com a duração de 1 a 2 anos (60 a 120 ECTS), em curso desde 2008/20096. Neste âmbito, é constituído o Mestrado em Ensino de História e Geografia, a funcionar desde o ano letivo de 2008-2009.

O Mestrado de Ensino da História e Geografia no 3. ${ }^{\circ}$ ciclo do Ensino Básico e no Ensino Secundário é condição legal para o exercício profissional de docência nestas duas disciplinas no sistema educativo português ${ }^{7}$. O decreto-lei 142/2008 determinava

\footnotetext{
${ }^{4}$ Portugal — Decreto-Lei n. ${ }^{\circ}$ 74/2006. «D. R. I Série A». 60 (2006-03-24) 2242-2257.

${ }^{5}$ MELO, 2015.

${ }^{6}$ VIEIRA et al., 2013.

${ }^{7}$ «D. R. II Série». 142 (2008-07-24).
} 
para uma formação bidisciplinar, que os candidatos tinham que apresentar como condições de acesso e ingresso uma Licenciatura ou habilitação equivalente em História e/ou Geografia, tendo que obter os restantes créditos na outra disciplina, num total de 50 créditos. Esta formação permitia que no sistema educativo português os profissionalizados pudessem lecionar nos dois grupos disciplinares, em História (grupo de recrutamento 400) e em Geografia (grupo de recrutamento 420). A tutela reconheceu as dificuldades inerentes a este Mestrado bidisciplinar, que implicava que os alunos da Licenciatura de História frequentassem UCs da área de Geografia e os da Licenciatura em Geografia UCs de História. Além disso, um dos problemas que a Universidade do Minho tinha era a falta de docentes da área da Didática de Geografia, o que implicava a contratação de docentes para lecionar as didáticas desta área, e o próprio estágio bidisciplinar era assegurado por Supervisores da área da História que supervisionavam e orientavam também na área da Geografia, apoiados pelos professores cooperantes de Geografia nas escolas. Este mestrado esteve a funcionar na Universidade do Minho desde o ano letivo de 2008-2009 até ao ano letivo de 2013-2014, embora alguns alunos tenham terminado apenas em 2018, após a defesa do Relatório de Estágio. Durante a vigência deste mestrado na UM formaram-se 34 mestres, que ficaram habilitados para lecionar História e Geografia, podendo concorrer aos dois grupos disciplinares. A partir do ano letivo de 2015-2016, e por decisão ministerial ${ }^{8}$, a formação de professores passou a ser de novo unidisciplinar, e na Universidade do Minho apenas foi criado o Mestrado em Ensino de História no 3. ${ }^{\circ} \mathrm{CEB}$ e no Ensino Secundário, do qual, desde 2018, é Diretora a Prof. ${ }^{a}$ Doutora Glória Solé, em substituição da Prof. ${ }^{a}$ Doutora Maria do Céu Melo, que se aposentou.

A estrutura curricular do Mestrado em Ensino de História e Geografia do 3. ${ }^{\circ}$ CEB e Ensino Secundário envolve cinco áreas científicas: Educação (EDU), Didática de História e Geografia (DHG), História (H) e Geografia (G), sendo a sua duração de 4 semestres (Tabela 1):

${ }^{8}$ Decreto-Lei n. ${ }^{\circ}$ 79/2014. «D. R. I Série». 92 (2014-05-14) 2819-2828. 
Tabela 1. Plano de estudos do Mestrado em Ensino da História e da Geografia

\begin{tabular}{|c|c|c|}
\hline Unidades Curriculares & Área Científica * & $\mathrm{S} / \mathrm{E} * *$ \\
\hline Sociologia da Educação e Profissão Docente & EDU & $1 / 0$ \\
\hline Desenvolvimento Curricular & EDU & $1 / 0$ \\
\hline Correntes Fundamentais da Pedagogia & EDU & $1 / 0$ \\
\hline Metodologia do Ensino da História & DHG & $1 / 0$ \\
\hline História e Memória & $\mathrm{H}$ & $1 / 0$ \\
\hline Tecnologia Educativa & EDU & $2 / 0$ \\
\hline Psicologia da Motivação e da Aprendizagem & EDU & $2 / 0$ \\
\hline Metodologia do Ensino da Geografia & DHG & $2 / 0$ \\
\hline Coordenação Educativa e Direção de Turma & PP & $2 / 0$ \\
\hline Dinâmicas Territoriais & G & $2 / 0$ \\
\hline Ética e Deontologia da Prática Docente & EDU & $3 / 0 p$ \\
\hline Psicologia da Adolescência & EDU & $3 / 0 p$ \\
\hline Organização da Escola & EDU & $3 / 0 p$ \\
\hline Avaliação e conceção de materiais didáticos de História e Geografia & DHG & $3 / 0 p$ \\
\hline Estágio Profissional & $\mathrm{PP}$ & 3 e $4 / 0$ \\
\hline
\end{tabular}

Legenda: * Educação: EDU; Didática de História e Geografia: DHG; História: H; Geografia: G; Prática profissional: PP ** S: Semestre; E: Estatuto; O: Obrigatória; Op: Opcional

A partir do ano letivo de 2015-2016 o Mestrado em Ensino de História no 3. ${ }^{\circ} \mathrm{CEB}$ e no Ensino Secundário entra em funcionamento na Universidade do Minho e apresenta a seguinte estrutura curricular (Tabela 2):

Tabela 2. Plano de estudos do Mestrado em Ensino da História e da Geografia

\begin{tabular}{l|c|c}
\hline \multicolumn{1}{c|}{ Unidades Curriculares } & Área Científica (1) & S /E** \\
\hline Currículo e Avaliação & EDU & $1 / O$ \\
\hline Psicologia do Desenvolvimento & EDU & $1 / 0$ \\
\hline Metodologia do Ensino da História I & DH & $1 / O$ \\
\hline Teoria da História e do Conhecimento Histórico & H & $1 / O$ \\
\hline Cidade e Centro Histórico & H & $1 / 0$ \\
\hline A Escola como Organização Educativa & EDU & $2 / O$ \\
\hline Metodologia do Ensino da História II & DH & $2 / O$ \\
\hline
\end{tabular}




\begin{tabular}{l|c|c}
\hline \multicolumn{1}{c|}{ Unidades Curriculares } & Área Científica (1) & S / E** \\
\hline Temas de História I & H & $2 / O$ \\
\hline Temas de História II & H & $2 / 0$ \\
\hline Tecnologia Educativa / & EDU & $3 / 0$ \\
\hline Processos Cognitivos e Aprendizagem & EDU \\
\hline $\begin{array}{l}\text { Inclusão e necessidades Educativas Especiais do domínio cognitivo } \\
\text { e motor }\end{array}$ & EDU & $3 / 0 p$ \\
\hline Correntes fundamentais da Pedagogia & EDU & $3 / 0 p$ \\
\hline Avaliação e Conceção de Mat. Didáticos de História & DH & $3 / 0$ \\
\hline Estágio Profissional / & PP & 3 e 4/O \\
\hline
\end{tabular}

Legenda: * Educação: EDU; Didática de História: DHG; História: H; Prática profissional: PP;

** S: Semestre; E: Estatuto; O: Obrigatória; Op: Opcional

Não pretendemos analisar as UCs de ambos os mestrados, pois o plano do curso está disponível na página do Instituto de Educação, nos Mestrados de Ensino. No Mestrado de História, a área científica de História é reforçada com as UCs de Teoria da História e do Conhecimento Histórico, Temas de História I e Temas de História II, partilhadas com alunos do Mestrado em História, bem como a UC de Cidade e Centro Histórico partilhada com os alunos do Mestrado em Arqueologia e Mestrado em Património Cultural. Apenas nos vamos ater à componente das didáticas específicas da História, que sai reforçada neste mestrado, pois são criadas duas UCs da componente Didática, nomeadamente Metodologias do Ensino de História I e II e mantém-se a UC de Avaliação e Conceção de Materiais Didáticos de História, agora só específica para a disciplina de História.

As UCs Metodologia do Ensino da História I e II pretendem desenvolver uma reflexão sobre os desafios educativos e sobre as orientações oficiais curriculares de História nos ensinos básico e secundário, sustentada pelos contributos teóricos e empíricos da investigação em Educação Histórica. Tem também como objetivo promover a aquisição de saberes e competências que permitam uma reflexão pessoal sobre momentos do processo ensino-aprendizagem desenvolvido na sala de aula (práticas e discursos, ideias tácitas, conhecimento substantivo e procedimental...), e valorizar a importância das práticas de ensino e aprendizagem de História em contextos não formais como museus, sítios... Estão presentes também saberes e competências adstritos à área da investigação em Educação Histórica.

A UC Avaliação e Conceção de Materiais Didáticos de História proporciona saberes e visa desenvolver competências de modo que os alunos sejam capazes de integrar contributos da investigação em Educação Histórica na avaliação e na conceção 
de materiais didáticos, e no desenho de situações de ensino e aprendizagem de História à luz das conceções do construtivismo social (projetos e planos de aulas: tarefas e instrumentos). Adota também como relevante a aquisição de conhecimentos adequados à investigação do ensino e aprendizagem da História.

No $2 .^{\circ}$ ano do Curso os alunos realizam o Estágio Profissional (3. ${ }^{\circ}$ $4 .^{\circ}$ semestres). De acordo com o plano de estudos, a UC de Estágio profissional integra 3 componentes de formação:

- Observação de Aulas e Desenho do Projeto: o ensino reflexivo e as perspetivas da educação em História; estratégias de observação de aulas; construção de projetos pedagógicos;

- Intervenção Pedagógica: o ensino reflexivo e as perspetivas da educação em História no desenvolvimento e avaliação de projetos pedagógicos;

- Seminários da Área de Docência (1. ${ }^{\circ}$ e 2. ${ }^{\circ}$ semestres): saberes disciplinares de apoio à docência e ao desenvolvimento dos projetos pedagógicos.

O estágio profissional visa a formação de professores reflexivos e autónomos, capazes de investigar a sua ação e de promover uma educação de orientação humanista e democrática, preparando o estudante para uma ação informada, deliberada, crítica, inovadora e ajustada aos contextos profissionais. Para além de promover uma intervenção crítica nos contextos pedagógicos no quadro de uma visão transformadora da pedagogia escolar baseada nos fundamentos epistemológicos da Educação Histórica, que se pauta pelo paradigma humanista, com uma abordagem construtivista do processo de ensino-aprendizagem, visa também incentivar uma cultura investigativa e colaborativa na formação profissional. Daí que nela seja dado papel medular ao desenvolvimento de um Projeto de Intervenção Pedagógica Supervisionada (PIPS) que exige certo domínio de procedimentos afetos à construção e implementação de instrumentos de recolha de dados sobre os contextos de intervenção e as práticas pedagógicas desenvolvidas, e à análise e reflexão das evidências encontradas 9 .

O módulo de Intervenção Pedagógica (Estágio) é desenvolvido em Escolas do Ensino Básico e Secundário ( $1 .^{\circ}$ semestre e $2 .^{\circ}$ semestre), que estabeleceram protocolos de colaboração com a UM. Os estagiários devem envolver-se na observação das práticas pedagógicas dos colegas do mesmo núcleo (escola), preparar e desenvolver um conjunto de aulas/práticas educativas na área de docência de História, planeando e discutindo as mesmas em reuniões semanais com os Supervisores (professores da universidade que lecionam as Didáticas Específicas) e com os Orientadores cooperantes que as observarão. O número médio de horas semanais das atividades realizadas nas escolas pelos estagiários é de 10 horas semanais e de lecionação de 24 tempos. Os professores

\footnotetext{
${ }^{9}$ VIEIRA et al., 2010; VIEIRA et al., 2013; MELO, 2015.
} 
estagiários devem também participar em atividades extracurriculares organizadas na escola, e elaborar ao longo do ano um portfólio que retrate o seu processo formativo nas diversas componentes do Estágio ${ }^{10}$. É também sua obrigação elaborar e implementar o Projeto de Intervenção Pedagógica Supervisionada (PIPS) no âmbito da sua prática pedagógica e que será implementado durante o seu estágio e produzido no final o relatório de estágio ${ }^{11}$.

A profissionalização culmina com a realização do estágio supervisionado, de um portfólio reflexivo elaborado ao longo do ano e com a defesa de um relatório final defendido em provas públicas. A classificação final integra todos os módulos da UC de Estágio Profissional em que se inclui a prática de ensino supervisionada e o relatório final. Determina-se, ainda, que a avaliação da unidade curricular referente à prática de ensino supervisionada «assume um lugar especial na verificação da aptidão do futuro professor para satisfazer, de modo integrado, o conjunto das exigências que lhe são colocadas pelo desempenho docente no início do seu exercício» ${ }^{12}$.

Na Universidade do Minho, no âmbito dos vários mestrados, o desenho do modelo de estágio que foi elaborado "procurou criar condições para que a investigação pudesse ocupar um lugar de relevo na prática e na elaboração do relatório, no quadro de uma formação reflexiva» e onde se prevê uma articulação estreita entre a prática pedagógica e o relatório final, ambos focados num «projeto de intervenção pedagógica supervisionada» que articula investigação e ensino ${ }^{13}$.

Embora o professor estagiário seja também um mestrando (diferente dos mestrados académicos), pretende-se que desenvolva competências profissionais mas também investigativas, que inter-relacione a prática com a investigação. Neste sentido, o professor será também um investigador social ${ }^{14}$, que procura analisar e refletir sobre o processo de aprendizagem dos alunos, no sentido de analisar como os alunos pensam em termos cognitivos e como aprendem, visando constantemente melhorar as suas estratégias e práticas pedagógicas.

Os projetos de investigação que foram realizados durante o estágio profissional deram origem a relatórios de estágio, onde a articulação entre a prática e a investigação é bem evidente no ensino da História. Para uma melhor explicitação do contributo destes relatórios de estágio em termos de investigação em Educação Histórica, procedeu-se à análise e posterior categorização por temáticas dos relatórios de estágio realizados desde 2009 a 2019, sendo que os relatórios até 2015 integravam também a área de Geografia, mas a análise recai apenas sobre as temáticas do projeto na área de História. Alguns dos

\footnotetext{
${ }^{10}$ Regulamento do Estágio dos Mestrados em Ensino. Braga: Universidade do Minho, 2011, Art. 14, adapt.

${ }^{11}$ VIEIRA et al., 2013; MELO, 2015.

${ }^{12}$ Decreto-Lei n. ${ }^{4}$ 43/2007. «D. R. I Série». 38 (2007-02-22) 1320-1328.

${ }^{13}$ VIEIRA et al., 2013: 2644.

${ }^{14}$ ALARCÃO, 2001; BARCA, 2004.
} 
projetos podem ser integrados em mais do que uma categoria, mas optou-se pela que era mais dominante em termos de temática (Tabela 3):

Tabela 3. Temáticas escolhidas pelos estudantes-investigadores — História (2009-2019) (N=58)

\begin{tabular}{|c|c|c|}
\hline Temáticas & Descritores & N. ${ }^{\circ}$ \\
\hline $\begin{array}{l}\text { Literacias - Textos visuais e } \\
\text { multimodais }\end{array}$ & $\begin{array}{l}\text { Todos os projetos cujo objeto é a interpretação de fontes históricas de } \\
\text { natureza icónica (cartoons e cartazes políticos, obras de arte, banda } \\
\text { desenhada, filmes de ficção, fotografias, mapas, documentários, notícias } \\
\text { televisivas...) pelos alunos. Incluem-se também projetos que versam a } \\
\text { produção do conhecimento histórico pelos alunos através de textos } \\
\text { visuais, como os desenhos, mapas mentais, mapas de conceitos, banda } \\
\text { desenhada, etc. }\end{array}$ & $\begin{array}{l}19 \\
+ \\
5\end{array}$ \\
\hline $\begin{array}{l}\text { Literacias - Textos verbais } \\
\text { escritos e orais }\end{array}$ & $\begin{array}{l}\text { Todos os projetos cujo objeto é a leitura e interpretação pelos alunos de } \\
\text { fontes históricas de natureza verbal escrita, notícias da imprensa escrita, } \\
\text { textos historiográficos, literários... Incluem-se também projetos que } \\
\text { versam a expressão escrita dos alunos através de mapas de conceitos, e } \\
\text { os que versam a produção de textos verbais escritos pelos alunos } \\
\text { (narrativas, textos dramáticos...). }\end{array}$ & 8 \\
\hline $\begin{array}{l}\text { Ideias tácitas, conceitos } \\
\text { estruturais e/ou substantivos }\end{array}$ & $\begin{array}{l}\text { Todos os projetos cujos objetos são as ideias tácitas e/ou prévias dos } \\
\text { alunos sobre certas temáticas ou conceitos históricos estruturais e/ou } \\
\text { substantivos. }\end{array}$ & $\begin{array}{l}6 \\
+ \\
6\end{array}$ \\
\hline Manuais escolares & $\begin{array}{l}\text { Todos os projetos que analisam os manuais escolares ou o seu papel na } \\
\text { aprendizagem orientada ou autónoma dos alunos. }\end{array}$ & 2 \\
\hline $\begin{array}{l}\text { Web, softwares, blogs, jogos } \\
\text { didáticos }\end{array}$ & $\begin{array}{l}\text { Todos os projetos que estudam a aprendizagem dos alunos feita através } \\
\text { destes recursos educativos. }\end{array}$ & 7 \\
\hline Valor formativo da História & $\begin{array}{l}\text { Todos os projetos que versam o papel da História na compreensão de } \\
\text { problemas do mundo (economia, sustentabilidade...) e/ou na promoção } \\
\text { de uma cidadania participativa. }\end{array}$ & 4 \\
\hline
\end{tabular}

Fonte: MELO, 2018. Elaboração de Solé (2020)

De acordo com a proposta de categorização realizada por $\mathrm{Melo}^{15}$, a grande maioria dos relatórios tem como temática dominante as literacias visuais, privilegiando-se a interpretação de fontes históricas de natureza icónica (cartoons e cartazes políticos, obras de arte, banda desenhada, filmes de ficção, fotografias, mapas, documentários, notícias televisivas...) pelos alunos, mas também a produção de conhecimento histórico pelos alunos através de textos visuais, como os desenhos, mapas mentais, mapas de conceitos, banda desenhada, etc. Há também uma certa preferência pelas literacias verbais, ou seja, a interpretação de fontes textuais, em que se integra nesta categoria a produção de narrativas. Um número significativo de alunos opta por escolher temáticas

\footnotetext{
${ }^{15}$ MELO, 2018.
} 
relacionadas com ideias tácitas, conceitos estruturais/meta-históricos e substantivos. De entre os conceitos estruturais ou meta-históricos mais frequentes, a opção recai na empatia histórica, significância histórica e multiperspetiva, embora a evidência histórica esteja muito presente, surge integrada nas literacias de interpretação de fontes visuais, multimodais e textuais.

Com o objetivo de compreender o papel da investigação no estágio em outros mestrados de outros ciclos que integram e formam também para a lecionação da área de História, embora não como disciplina autónoma, analisou-se um corpus de 14 relatórios, desde 2011 a 2017, no Mestrado em Educação Pré-Escolar e Ensino do 1. ${ }^{\circ}$ Ciclo do Ensino Básico e no Mestrado em Ensino do $1 .^{\circ} \mathrm{CEB}$ e do $2 .{ }^{\circ} \mathrm{CEB}$ e a partir de 2016-2017 no Mestrado em Ensino do 1. ${ }^{\circ}$ CEB e Ensino de Português e História e Geografia de Portugal. Os alunos destes mestrados podem escolher a área disciplinar em que pretendem realizar o seu Projeto de Intervenção Pedagógica Supervisionada (PIPS), assim ao longo deste período a professora Glória Solé orientou 15 projetos, sendo 14 relacionados com a Educação Histórica, organizados por temáticas categorizadas em três categorias: Narrativas, Educação Patrimonial e Tecnologia de Informação e Comunicação (TIC) e Conceitos Meta-Históricos. O quadro abaixo sistematiza as temáticas escolhidas pelos alunos desde 2011 a 2017 (Tabela 4):

Tabela 4. Temáticas dos Relatórios de Estágio do Mestrado em Ensino do 1. e 2. ${ }^{\circ}$ CEB (2011-2017) (N=14)

\begin{tabular}{|c|c|c|}
\hline Temáticas & Descritores & N. ${ }^{\circ}$ \\
\hline Narrativas & $\begin{array}{l}\text { Todos os projetos cujo foco é leitura e interpretação pelos alunos de } \\
\text { fontes de natureza verbal escrita ao nível da literatura como contos, } \\
\text { mitos, lendas, literatura infantil histórica, banda desenhada... Incluem-se } \\
\text { também projetos que versam a expressão escrita dos alunos (narrativas, } \\
\text { textos dramáticos, construção de BDs). }\end{array}$ & 4 \\
\hline $\begin{array}{l}\text { Educação Histórica e } \\
\text { Patrimonial e TIC }\end{array}$ & $\begin{array}{l}\text { Todos os projetos cujo foco se relaciona com a educação histórica e } \\
\text { patrimonial, versando monumentos, sítios patrimoniais ou objetos, } \\
\text { visitas de estudo, quer in loco quer virtual com recurso a TIC (Google } \\
\text { maps e/ou geocaching) para desenvolver o pensamento histórico, } \\
\text { relacionando com conceitos meta-históricos como evidência histórica, } \\
\text { significância histórica e consciência histórica. }\end{array}$ & 4 \\
\hline Conceitos Meta-Históricos & $\begin{array}{l}\text { Todos os projetos cujo foco se relaciona com os conceitos meta- } \\
\text { históricos: mudança, tempo, evidência, significância, explicação histórica, } \\
\text { causalidade e consciência histórica, com recurso à exploração de fontes } \\
\text { diversas como linhas de tempo, genealogias, objetos, imagens, } \\
\text { fotografias, cartoons, documentos escritos... }\end{array}$ & 6 \\
\hline \multicolumn{2}{|l|}{ Total } & 14 \\
\hline
\end{tabular}

Fonte: MELO (2018). Elaboração de Solé (2020) 
Embora o número de relatórios seja inferior ao do Mestrado em Ensino de História, e dada a especificidade destes mestrados, em que realizam o relatório da prática de estágio supervisionado em dois ciclos (1. ${ }^{\circ} \mathrm{CEB}$ e $\left.2 .^{\circ} \mathrm{CEB}\right)$, há de certa forma um equilíbrio entre as temáticas escolhidas, embora a escolha recaia um pouco mais por trabalharem os conceitos meta-históricos, principalmente evidência, significância, temporalidade e empatia histórica.

\section{A PÓS-GRADUAÇÃO EM EDUCAÇÃO HISTÓRICA NA UNIVERSIDADE DO MINHO}

Na década de 90, com o incremento da oferta formativa de pós-graduação ao nível dos Mestrados em Educação, em 1998 pela Resolução SU-35/98 de 26 de outubro, é criado o Mestrado em Supervisão Pedagógica em Ensino da História, que visava formar mestres em Supervisão Pedagógica na área de História e habilitá-los assim para a Supervisão nesta área disciplinar. Os alunos que completassem a parte escolar do curso obtinham um diploma de especialização e os que terminassem o curso com a dissertação obtinham o grau de Mestre.

A primeira edição realizou-se no ano letivo de 1999-2000, seguindo-se várias edições até 2012. De 1999 a 2012, esteve ininterruptamente a funcionar, à exceção de um ano, em que não funcionou o $1 .^{\circ}$ ano, por as docentes da área da Educação em História se encontrarem de licença sabática. Em 2007, ao abrigo do disposto no artigo $4 .^{\circ}$ da resolução n. ${ }^{\circ}$ SU-25/2006 de 30 de janeiro, e publicado no Despacho n. ${ }^{\circ}$ 755/2007 de 15 de janeiro, o Mestrado académico é reestruturado e a sua designação é alterada para Mestrado em Supervisão Pedagógica em Ensino de História e Ciências Sociais, tendo sido aprovado um novo plano do curso que entrou em vigor no ano letivo de 2006/2007, e passou a ter 120 créditos de acordo com a exigência do Sistema Europeu de transferência de créditos para a obtenção do grau de mestre, com a duração de dois anos. No plano de estudos da reformulação deste mestrado há integração das Ciências Sociais, possibilitando a especialização em outras disciplinas das Ciências Sociais, para além da História (Tabela 5): 
Tabela 5. Plano de estudos do Mestrado em Supervisão Pedagógica em ensino de História e Ciências Sociais

\begin{tabular}{|c|c|c|}
\hline Unidades Curriculares & Área Científica (1)* & $\mathbf{S} / \mathbf{E}^{* *}$ \\
\hline \multicolumn{3}{|l|}{$1 .{ }^{\circ}$ ano } \\
\hline Supervisão Pedagógica em Ensino de História e Ciências Sociais & SPEHCS & $\mathrm{S} / \mathrm{O}$ \\
\hline Metodologia do Ensino de História e Ciências Sociais & MEHCS & $\mathrm{S} / \mathrm{O}$ \\
\hline Metodologia de Investigação em Educação & MEHCS & $\mathrm{S} / \mathrm{O}$ \\
\hline Opção História & $\mathrm{H}$ & S/Op \\
\hline $\begin{array}{l}\text { Observação de Práticas de Ensino e de Formação em História e } \\
\text { Ciências Sociais }\end{array}$ & SPEHCS & $\mathrm{S} / \mathrm{O}$ \\
\hline $\begin{array}{l}\text { Investigação em Supervisão Pedagógica em Ensino de História e } \\
\text { Ciências Sociais }\end{array}$ & SPEHCS & $\mathrm{S} / \mathrm{O}$ \\
\hline $\begin{array}{l}\text { Avaliação em Supervisão Pedagógica em Ensino de História e } \\
\text { Ciências Sociais }\end{array}$ & SPEHCS & $\mathrm{S} / \mathrm{O}$ \\
\hline Opção Ciências Sociais & CS & S/Op \\
\hline Opção Educação/Psicologia & $\mathrm{ED} / \mathrm{PSI}$ & $\mathrm{S} / \mathrm{O}$ \\
\hline \multicolumn{3}{|l|}{$2 .^{\circ}$ ano } \\
\hline Seminário de Orientação da Dissertação & SPEHCS & Anual \\
\hline Dissertação & SPEHCS & Anual \\
\hline
\end{tabular}

Legenda: * Supervisão Pedagógica em Ensino de História e Ciências Sociais: SPEHCS; Metodologia do Ensino de História e Ciências Sociais: MEHCS; História: H; ${ }^{* *}$ S: Semestre; E: Estatuto; O: Obrigatória; Op: Opcional

Durante esse período, de mais de uma década, foram defendidas um total de 55 dissertações no âmbito deste mestrado, primeiro em Supervisão Pedagógica em Ensino da História e depois de 2007-08 em Supervisão Pedagógica em Ensino de História e Ciências Sociais, orientadas pelas Professoras Doutoras Isabel Barca, Maria do Céu Melo, Olga Magalhães e algumas em coorientação, com a Doutora Júlia Castro, o Prof. Pedro Rosário da área da Psicologia, a Prof. ${ }^{a}$ Ana Amélia Carvalho da área das TIC e a Prof. ${ }^{a}$ Ana Francisca Azevedo da área da Geografia. Nem sempre as datas das defesas podem ser associadas a anos letivos, pois vários alunos atrasaram-se na entrega das dissertações.

O Mestrado em Supervisão Pedagógica em Ensino de História e Ciências Sociais foi extinto, após três anos consecutivos sem haver candidatos, isto resultante, por um lado, da abertura do Mestrado em Ensino de História e Geografia profissionalizante e, por outro, da estagnação na carreira docente, após 2010, o que desincentivou os professores a procurarem os mestrados académicos para progressão na carreira de quatro anos, concedida aos Mestrados com vertente de Ensino na área de docência. Esta situação esteve também associada à extinção dos restantes Mestrados em Educação (académicos) 
das diferentes áreas disciplinares, pois este conjunto de circunstâncias contribuiu para a extinção dos mesmos, por falta de candidatos suficientes para o seu funcionamento. Tal como procedemos para os relatórios de estágio, procurou-se analisar também no mestrado académico as temáticas escolhidas pelos investigadores, construindo-se a seguinte categorização por temáticas/objeto de estudo (Tabela 6):

Tabela 6. Temáticas escolhidas pelos investigadores dos Mestrados em Supervisão Pedagógica de História (e Ciências Sociais) (2001-2012) $(\mathrm{N}=55)$

\begin{tabular}{|c|c|c|}
\hline Temáticas & Descritores & N. ${ }^{\circ}$ \\
\hline $\begin{array}{l}\text { Literacias - Textos visuais, } \\
\text { multimodais, verbais escritos } \\
\text { e orais }\end{array}$ & $\begin{array}{l}\text { Todas as dissertações cujo objeto é a interpretação de fontes históricas } \\
\text { de natureza icónica (cartoons e cartazes políticos, obras de arte, banda } \\
\text { desenhada, filmes de ficção, fotografias, mapas, documentários, notícias } \\
\text { televisivas...) e auditiva (música) pelos alunos. Integram-se também as } \\
\text { dissertações cujo objeto é a leitura e interpretação pelos alunos de } \\
\text { fontes históricas de natureza verbal escrita, notícias da imprensa escrita, } \\
\text { textos historiográficos, literários... e/ou a produção de textos narrativos } \\
\text { pelos alunos. }\end{array}$ & 11 \\
\hline $\begin{array}{l}\text { Ideias tácitas e/ou prévias e } \\
\text { conceitos substantivos }\end{array}$ & $\begin{array}{l}\text { Todas as dissertações cujos objetos são as ideias tácitas e/ou prévias dos } \\
\text { alunos sobre certas temáticas, conceitos históricos/ substantivos, } \\
\text { conhecimento histórico sobre um conceito ou temática (ex. Guerra Fria). }\end{array}$ & 6 \\
\hline $\begin{array}{l}\text { Conceitos estruturais/meta- } \\
\text { históricos }\end{array}$ & $\begin{array}{l}\text { Todas as dissertações cujos objetos são os conceitos estruturais/meta- } \\
\text { históricos (significância histórica, explicação histórica, empatia histórica, } \\
\text { narrativa, mudança, causalidade, multiperspetividade, temporalidade) } \\
\text { quer em alunos quer por parte dos professores e consciência histórica. }\end{array}$ & 16 \\
\hline Património e identidade & $\begin{array}{l}\text { Todas as dissertações que versam o património cultural, o meio local, a } \\
\text { exploração sítios arqueológicos, de artefactos, objetos e/ou réplicas em } \\
\text { contexto formal e informal, e a construção de museus em sala de aula. } \\
\text { Integram-se também dissertações que relacionam o património cultural } \\
\text { com a identidade. }\end{array}$ & 8 \\
\hline Manuais escolares & $\begin{array}{l}\text { Todas as dissertações que analisam os manuais escolares ou o seu papel } \\
\text { na aprendizagem orientada ou autónoma dos alunos. }\end{array}$ & 3 \\
\hline $\begin{array}{l}\text { Web, softwares, blogs, jogos } \\
\text { didáticos, podcast, visitas de } \\
\text { estudo virtuais }\end{array}$ & $\begin{array}{l}\text { Todas as dissertações que estudam a aprendizagem dos alunos feita } \\
\text { através destes recursos educativos. }\end{array}$ & 4 \\
\hline Valor formativo da História & $\begin{array}{l}\text { Todas as dissertações que versam o papel da História na compreensão } \\
\text { de problemas do mundo, na valorização do ensino da História para a } \\
\text { formação e/ou na promoção de uma cidadania participativa. }\end{array}$ & 2 \\
\hline $\begin{array}{l}\text { Currículos, políticas } \\
\text { educativas e avaliação }\end{array}$ & $\begin{array}{l}\text { Todas as dissertações cujo objeto é analisar os currículos, as políticas } \\
\text { educativas em História, bem como as que incidem sobre a avaliação } \\
\text { (processos de regulação das aprendizagens, avaliação de competências } \\
\text { históricas e metacognição). }\end{array}$ & 5 \\
\hline
\end{tabular}

Fonte: MELO, 2018. Elaboração de Solé (2020) 
De acordo com a proposta de categorização adaptada por Glória Solé a partir de Melo $^{16}$ e com base nas dissertações analisadas que foram identificadas na base de dados da Universidade do Minho (Repositorium), constata-se a predominância de dissertações cuja temática se relaciona com conceitos meta-históricos, pois de um total de 55 dissertações, 16 investigadores procuraram investigar sobre este enfoque proposto pela Educação Histórica. As literacias visuais e textuais, relacionadas com a interpretação de fontes variadas em suporte visual, multimodal, textual ou oral, mas também com mensagens convergentes ou divergentes, é outra temática muito presente, com 11 investigadores a optarem por estes tópicos. Um número significativo de investigadores optou por escolher temáticas relacionadas com ideias tácitas e prévias, bem como sobre conceitos substantivos, como por exemplo a Guerra Fria. No entanto, muitas das dissertações que recaem na categoria de dissertações relacionadas com conceitos meta-históricos também integram abordagens aos conceitos substantivos a serem trabalhados em sala de aula com os alunos, sobre temáticas como 25 de Abril, colonialismo, interculturalidade, etc. De entre os conceitos meta-históricos mais frequentes, a opção recai na narrativa, empatia histórica, significância histórica, explicação histórica e multiperspetiva, embora a evidência histórica esteja muito presente, integrada nas literacias visuais, multimodais e textuais. Com alguma relevância, o património e o trabalho com fontes patrimoniais em sala de aula, ou em contextos não formais, está bastante presente no cômputo das dissertações, com 8 a versarem esta problemática, muitas vezes em articulação com questões de identidade local ou global. Outros investigadores (5) optaram por estudar os currículos, as políticas educativas e os processos de avaliação ao nível da autorregulação das aprendizagens em História e da metacognição realizada pelos alunos, procurando averiguar o impacto destas políticas e reguladores das aprendizagens nos processos de ensino-aprendizagem e como são interpretadas pelos professores de História. Com uma expressão um pouco menos significativa, surgem dissertações relacionadas com o valor formativo da História (2) e com os manuais e seu uso pelos alunos e professores (3).

Esta diversidade de temáticas e a predominância de umas em relação a outras, de certa forma, expressa o contributo e a influência, mais ou menos direta de cada orientador, que detém uma especialização diferenciada, pelo seu percurso investigativo em Educação Histórica, e direciona o objeto de estudo para certos enfoques e temáticas no âmbito da investigação em Educação Histórica. Durante mais de uma década formaram-se 55 mestres, que incorporaram os princípios teóricos e empíricos da Educação Histórica a nível da investigação, e que contribuíram muito com os seus estudos empíricos e implicações dos seus resultados para o ensino da História e afirmação da Educação Histórica em Portugal.

${ }^{16}$ MELO, 2018. 
Esses contributos epistemológicos da Educação Histórica e a afirmação desta área a nível nacional e internacional saiu reforçado com 10 doutoramentos orientados pela Professora Isabel Barca e 1 doutoramento orientado pela Professora Maria do Céu Melo e 1 orientado pela Professora Maria Luísa Varela de Freitas. Também a pós-graduação através de Estágios Científicos Avançados ao nível do Doutoramento, mas também de Pós-Doutoramento, a maior parte das vezes por investigadores brasileiros de várias universidades federais e estaduais, mas também investigadores portugueses e espanhóis, tem reforçado o reconhecimento científico da investigação em Educação Histórica desenvolvida em Portugal, e em particular na Universidade do Minho.

A disseminação da investigação em Educação Histórica tem tido claros reflexos no ensino de história no nosso país, e também nos referenciais normativos, como o comprovam os documentos oficiais, Currículo Nacional do Ensino Básico - Competências Essenciais ${ }^{17}$ e as Metas de Aprendizagem ${ }^{18}$, que incorporam contributos na sua formulação da Educação Histórica, no entanto, o primeiro documento foi revogado em 2012, e o segundo substituído pelas Metas Curriculares para o $2 .^{\circ}$ e $3 .^{\circ} C E B^{19}$. Em 2018 são aprovadas as Aprendizagens Essenciais $(A E)^{20}$, na sua elaboração colaboraram investigadores da área Educação História e a Associação de Professores de História. As Aprendizagens Essenciais integram claramente os princípios epistemológicos da Educação Histórica, e de acordo com o documento normativo estas

foram elaboradas numa perspetiva construtivista de encarar o ensino-aprendizagem e visam que o aluno adquira uma consciência histórica que lhe permita assumir uma posição crítica e participativa na sociedade, reconhecendo a utilidade da História para compreender de forma integrada o mundo em que vive e para a construção da sua identidade individual e coletiva ${ }^{21}$.

Neste capítulo procurou-se realizar uma incursão pelo trabalho que foi realizado durante três décadas na Educação Histórica em Portugal e em particular na Universidade do Minho, nomeadamente ao nível da disseminação da Educação Histórica através da formação inicial, doutoral e pós-doutoral, mas também refletir sobre as Jornadas de Educação Histórica como um espaço nacional e internacional de consolidação epistemológica. A investigação em Educação Histórica realizada em Portugal é reconhecida internacionalmente pela comunidade científica internacional, mas não só, ela tem tido

\footnotetext{
${ }^{17}$ PORTUGAL. Ministério da Educação. DEB, 2001.

${ }^{18}$ PORTUGAL. Ministério da Educação. DGIDC, 2010.

${ }^{19}$ PORTUGAL. Ministério da Educação e Ciência, 2013; SOLÉ, 2017b.

${ }^{20}$ PORTUGAL. Ministério da Educação e Ciência. DGE, 2018.

${ }^{21}$ SOLÉ, 2019: 509
} 
impacto nas políticas educativas no ensino da História em Portugal e nas práticas em sala de aula de muitos professores de História. Reconhecemos que ainda há caminho a fazer, mas este faz-se caminhando...

\section{LEGISLAÇÃO}

DECRETO-LEI n. ${ }^{\circ}$ 74/2006. «D. R. I Série A». 60 (2006-03-24) 2242-2257.

DESPACHO n. ${ }^{\circ}$ 755/2007. «D. R. II Série». 10 (2007-01-15) 1151.

DECRETO-LEI n. ${ }^{\circ}$ 43/2007. «D. R. I Série». 38 (2007-02-22) 1320-1328.

«D. R. II Série». 142 (2008-07-24).

DECRETO-LEI n. ${ }^{\circ}$ 79/2014. «D. R. I Série». 92 (2014-05-14) 2819-2828.

\section{BIBIOGRAFIA}

ALARCÃO, Isabel (2001) — Professor-investigador: Que sentido? Que formação? Disponível em <www.Inafop.pt/revista/docs/textoisabelalarcao.html>.

BARCA, Isabel (2004) - Aula Oficina: do Projecto à Avaliação. In BARCA, Isabel, org. - Para uma Educação Histórica com Qualidade: Actas das IV Jornadas Internacionais de Educação Histórica. Braga: CIEd/Universidade do Minho; Instituto de Educação e Psicologia/Universidade do Minho, p. 131-144. (2009) - Investigação Histórica em Portugal: esboço de uma síntese. In BARCA, Isabel; SCHMIDT, Maria Auxiliadora, org. - Educação Histórica: Investigação em Portugal e no Brasil. Actas das 5. ${ }^{\text {as }}$ Jornadas Internacionais de Educação Histórica. Braga: CIEd/Universidade do Minho, p. 11-27.

BARCA, Isabel; ALVES, Luís Alberto (2016) — Introdução. In BARCA, Isabel; ALVES, Luís Alberto, org. Educação Histórica: Perspetivas de Investigação Nacional e Internacional. Porto: CITCEM, p. 6-9.

MELO, M. Céu (2015) - A formação de professores de História em Portugal: práticas pedagógicas e investigativas. «História Hoje», vol. 4, n. ${ }^{\circ}$ 7, p. 41-61.

(2018) - As partituras iniciáticas de estudantes em investigação e em ensino da História. No prelo.

PORTUGAL. Ministério da Educação. DEB (2001) - Currículo Nacional do Ensino Básico - Competências Essenciais. Lisboa: Ministério da Educação. Disponível em <https://alvarovelho.net/attachments/article/39/LivroCompetenciasEssenciais.pdf>.

PORTUGAL. Ministério da Educação. DGIDC (2010) - Metas de Aprendizagem. Lisboa: Ministério da Educação. Disponível em <http://metasdeaprendizagem.dge.mec.pt/metasdeaprendizagem.dge.mec. $\mathrm{pt} /$ sobre-o-projecto/documentos-de-referencia/index.html>.

PORTUGAL. Ministério da Educação e Ciência (2013) - Metas Curriculares para o $2 .^{\circ}$ e $3 .^{\circ} \mathrm{CEB}$. Lisboa: Ministério da Educação. Disponível em <https://www.dge.mec.pt/sites/default/files/ficheiros/metas curriculares_hist_3_ciclo.pdf>.

PORTUGAL. Ministério da Educação e Ciência. DGE (2018) - Aprendizagens Essenciais (AE). Lisboa: Ministério da Educação. Disponível em <https://www.dge.mec.pt/aprendizagens-essenciais-ensino -basico>.

SOLÉ, Glória (2017a) - Educação Histórica e Educação Patrimonial: desafios da investigação em Portugal. In MIRALLES, Pedro; GÓMEZ, Cosme J.; RODRÍGUEZ, Raimundo, eds. - La enseñanza de la historia en el Siglo XXI: Desarrollo y evaluación de competencias históricas para una ciudadanía democrática. Múrcia: Universidade de Múrcia, p. 145-166. Disponível em <http://libros.um.es/editum/ catalog/book/1781>.

(2017b) - As competências específicas no ensino da História: a dimensão da temporalidade para a compreensão histórica. «CLÍO: History and History Teaching», n. ${ }^{\circ}$ 43, p. 89-112. 
(2019) - Temas controversos da história e políticas educativas em Portugal: a inter-culturalidade e a integração do «outro» nos documentos oficiais e nos manuais escolares. MORENO-VERA, Juan; MONTEAGUDO FERNÁNDEZ, José, eds. - Temas controvertidos en el aula: ensenãr y aprender historia en la era de la posverdad. Múrcia: Editum, Editora de la Universidad de Murcia, p. 503-522. (2020) - Aprendizagem histórica e formação de professores dos anos iniciais na Universidade do Minho (Portugal): a articulação entre a prática e a investigação em Educação Histórica. «Roteiro», n. ${ }^{\circ}$ 45, p. 1-26. Disponível em <https://doi.org/10.18593/r.v45i0.21997>.

VIEIRA, Flávia et al. (2010) - No caleidoscópio da supervisão: imagens da formação e da pedagogia. 2. ${ }^{\mathrm{a}}$ edição. Mangualde: Ed. Pedago.

(2013) - O papel da investigação na prática pedagógica dos mestrados em ensino. In SILVA, Bento et al., orgs. - Atas do XII Congresso Internacional Galego-Português de Psicopedagogia. Braga: CIEd/Universidade do Minho, p. 2641-2655. 



\title{
EDUCAÇÃO HISTÓRICA - DIÁLOGOS COM DIVERSOS MEIOS E AGENTES EDUCATIVOS
}

\author{
MARÍLIA GAGO* \\ MARIANA LAGARTO**
}

\begin{abstract}
Resumo: O percurso sustentado da Educação Histórica em Portugal nas últimas três décadas pautou-se pelo diálogo estabelecido entre os diversos meios e agentes educativos. Isabel Barca fundou esta "escola» na Universidade do Minho que passou a ser um centro de investigação, nesta área de saber, articulando a teoria e as práticas educativas. Para tal, a Associação de Professores de História revela-se um parceiro fundamental que permitiu a disseminação das propostas quer de investigação quer de práticas educativas em diferentes contextos. Assim, para além do fomento da investigação ao nível do Mestrado, Doutoramento e Projetos de Investigação, existia a possibilidade de contribuir para a formação contínua de professores de História.
\end{abstract}

Palavras-chave: Educação Histórica; Investigação em Educação Histórica; Formação de Professores; Associação de Professores de História.

Abstract: The sustained path of History Education in Portugal in the last three decades has been guided by the dialogue established between the various educational media and agents. Isabel Barca founded this "school» at the University of Minho, which became a research center in this area of knowledge, articulating theory and practices. To this end, the Portuguese Association of History Teachers (APH) proves to be a fundamental partner that allowed the dissemination of proposals, both for research and educational practices in different contexts. Thus, in addition to fostering research at the level of the Master's, PhD and Research Projects, there was the possibility of contributing to the continuous teacher education of History teachers.

Keywords: History Education; History Education Research; Teacher Education; Association of History Teachers.

\section{INVESTIGAÇÃO EM EDUCAÇÃO HISTÓRICA EM PORTUGAL - TEORIA E PRÁTICAS}

A Educação Histórica desde meados da década de 1990 e início do século XXI revelou-se uma área que causou, no início, estranheza, mas depois com a sua aposta na inter-relação da teoria e práticas de Ensino de História, situando-se a investigação na sua interface, começou a entranhar-se. Assim, este novo campo que surgia em Portugal propunha que através das propostas da aprendizagem situada, do saber histórico e da sua epistemologia (conceitos substantivos e meta-históricos), bem como dos procedimentos metodológicos da pesquisa social, explorasse as conceções e práticas dos diversos agentes educativos. Deste modo, já no âmbito da disciplina da Metodologia do ensino da História e Ciências Sociais, da licenciatura em História e Ciências Sociais (ensino de),

\footnotetext{
* Centro de Investigação Transdisciplinar Cultura, Espaço e Memória (CITCEM) e Universidade do Minho.

** Centro de Investigação Transdisciplinar Cultura, Espaço e Memória (CITCEM).
} 
em que algumas experiências de sala de aula partilhavam estes princípios, foi no âmbito do Mestrado Académico em Educação, Supervisão Pedagógica e Metodologia do Ensino da História (1999-2012) coordenado pela Professora Doutora Isabel Barca que, de forma mais sistemática, se desenvolveram estudos em Portugal focalizados na articulação da História, da Epistemologia da História e da Cognição Situada. A primeira edição deste Mestrado Académico situa-se no ano letivo de 1999/2000, contando com 8 mestrandos (Abílio Barreira, Adriano Fernandes, Flávio Ribeiro, Maria dos Anjos Morais, Maria Isabel Cruz, Marília Quintal Gago, Olga Gracinda Moreira, Roque Costa Gonçalves), que desenvolveram estudos diversos - desde questões associadas à supervisão, passando pelas ideias dos estudantes relacionadas com evidência, a multiperspetividade narrativa e diversos recursos e fontes (internet, televisão, objetos arqueológicos, museologia...), bem como preocupações relacionadas com a cidadania e identidade. A primeira dissertação deste mestrado intitula-se Concepções dos alunos acerca da variância da narrativa histórica - um estudo com alunos dos anos iniciais do $2 .^{\circ}$ e $3 .^{\circ}$ ciclos do ensino básico ${ }^{1}$. Com este Mestrado surgiram as Jornadas Internacionais de Educação Histórica - um dos frutos destes passos iniciais de articulação da teoria com a prática².

A partir desta altura, foi dada continuidade aos estudos no âmbito do referido Mestrado, mas concomitantemente foram desenvolvidos vários estudos de investigação mais aprofundados ao nível do ciclo de estudos de Doutoramento, com a orientação da Professora Doutora Isabel Barca, bem como estudos de investigação no âmbito de dois projetos de investigação em Consciência Histórica: Teoria e Práticas I e II (Hicon I e Hicon II), financiados pela Fundação para a Ciência e Tecnologia, entre 2002-2011, POCTI/CED/49106/2002 e PTDC/CED/72623/2006, respetivamente. Como produtos destes projetos de investigação, destacam-se 3 teses de Doutoramento e 4 dissertações de Mestrado, no âmbito do Projeto Hicon I, e 1 Pós-Doutoramento em Educação Histórica, 2 teses de Doutoramento, 2 dissertações de Mestrado e uma bolsa de Mestrado.

O primeiro estudo de doutoramento no âmbito das Ciências da Educação orientado pela Professora Doutora Isabel Barca foi o de Olga Magalhães, em 2001, na Universidade de Évora. Este estudo, de foro quantitativo, debruçava-se sobre as conceções de professores sobre História e ensino da História, pretendendo perceber a forma como os professores de História concebem a disciplina que lecionam e, por outro, destrinçar eventuais implicações dessas conceções no modo como entendem o ensino da sua disciplina e, portanto, as suas práticas docentes ${ }^{3}$.

Sediados na Universidade do Minho, foram desenvolvidos oito estudos de doutoramento entre 2006 e 2017. Estes estudos são diversos em termos de objetivos e objetos de estudo, contando com estudos acerca de conceções de estudantes e professores, bem

\footnotetext{
${ }^{1}$ GAGO, 2001.

${ }^{2}$ Ver Solé, nesta publicação.

${ }^{3}$ MAGALHÃES, 2002.
} 
como de currículo, manuais escolares e avaliação em articulação como uma vasta panóplia de conceitos da ciência histórica e da consciência histórica.

$\mathrm{O}$ estudo qualitativo, descritivo de Castro ${ }^{4}$ focalizou-se no conceito de interculturalidade, imbrincado nos conceitos de significância e empatia histórica, especialmente, em relação às ideias de jovens portugueses do ensino secundário. A maioria destes jovens revelou ideias em torno do conceito de diferença que nos sugerem um pensamento histórico menos sofisticado e mais restrito; mas, outros jovens apresentaram um pensamento histórico mais sofisticado lidando com ideias de diversidade, relação e universalidade numa perspetiva intercultural.

Partilhando a preocupação de compreender como futuros professores de História e professores de História Portugueses concebiam a narrativa histórica na sala de aula, bem como as suas conceções expressavam a sua consciência histórica, Gago ${ }^{5}$ desenvolveu um estudo qualitativo seguindo a Grounded Theory. Este estudo contou com a participação, no seu estudo final, de 67 futuros professores e professores de História, selecionados de forma propositada para promover a diversidade em termos de formação inicial, tempo de experiência profissional, local de lecionação (privado ou público) e região de Portugal. A entrevista semiestruturada permitiu fazer emergir os perfis de ideias de narrativa e consciência histórica dos participantes e concluir-se que prevalece um perfil de ideias em linha com uma consciência histórica de tipo exemplar.

Simão deslocou a sua atenção investigativa para os alunos e assim desenvolveu o seu estudo relativamente ao modo como os alunos constroem evidência histórica ${ }^{6}$. $\mathrm{O}$ estudo desenvolvido de natureza descritiva e com uma abordagem predominantemente qualitativa contou com alunos do $8 .^{\circ}$ ano e $11 .^{\circ}$ anos de escolaridade. Os resultados encontrados mostram a diversidade e oscilação de ideias sobre evidência em alunos de 3. ${ }^{\circ}$ ciclo e ensino secundário e permitem adiantar sugestões para a utilização de fontes diversas em sala de aula de uma forma problematizadora.

Conjugando ideias de alunos e professores, Pinto $^{7}$ propôs compreender de que forma alunos e professores de História interpretam a evidência de um sítio histórico. O estudo, essencialmente qualitativo, fundado na Grounded Theory, contou no estudo principal com a participação de 87 alunos do $7 .^{\circ}$ e $10 .^{\circ}$ anos de escolaridade e com 6 professores de História das 7 turmas participantes. Os instrumentos consistiram num "guião-questionário» para os alunos e dois breves questionários para os professores, seguidos de entrevistas de seguimento. Constatou-se que os alunos inferiam evidência a partir de detalhes concretos e demonstraram ideias em linha com um passado fixo.

\footnotetext{
${ }^{4}$ CASTRO, 2006.

${ }^{5}$ GAGO, 2007; GAGO, 2018.

${ }^{6}$ SIMÃO, 2007.

${ }^{7}$ PINTO, 2011; PINTO, 2016.
} 
Os professores concebiam o uso de fontes patrimoniais para a divulgação do património, a consolidação de conhecimento e a construção de um sentido identidade local.

Com um enfoque na avaliação em História e na competência dos alunos de $12 .{ }^{\circ}$ ano de escolaridade ao nível da evidência histórica, Veríssimo ${ }^{8}$, através de um estudo de natureza qualitativa e descritiva, procurou perceber, através de entrevistas e questionários, as ideias dos alunos de $12 .^{\circ}$ ano de escolaridade acerca de evidência histórica $\mathrm{e}$ como estas se podem refletir nos resultados dos exames de História A do $12 .^{\circ}$ ano de escolaridade. Da análise de dados conclui-se que os alunos demonstram debilidades, utilizando as fontes apenas para citar informação, que são verificadas nos resultados obtidos pelos alunos nos exames que parecem estar relacionadas com a forma como a História é ensinada.

Pensando no papel do manual de História no desenvolvimento de competências, Afonso ${ }^{9}$ desenvolveu um estudo com professores e alunos do ensino secundário. $\mathrm{O}$ estudo realizado contou, no seu estudo final, com 117 participantes: 5 professores a lecionar a disciplina de História A em escolas do norte, centro e centro/sul do país, e os respetivos alunos. A entrevista semiestruturada e os materiais históricos propostos no manual adotado e no caderno de atividades foram os instrumentos usados para a recolha de dados. Concluiu-se que o manual de História A é um instrumento didático-pedagógico privilegiado quer pelos alunos quer pelos professores, embora não seja o recurso exclusivo. Os alunos interpretam as fontes de forma genérica, mas existem já alguns alunos que demonstram interpretar as fontes de forma inferencial, apresentando uma síntese pessoal e fundamentada.

Num contexto diferente do português, Ngungui ${ }^{10}$ desenvolveu um estudo que pretendia perceber como os alunos em contexto angolano constroem as suas ideias em História e que tipos de conceções históricas e educativas manifestam os professores, numa experiência de aula oficina com caráter construtivista. Este estudo, em linha com os anteriores, alicerçou-se numa metodologia qualitativa ancorada na Grounded Theory, contando com 74 alunos da 10. ${ }^{a}$ e 11. ${ }^{a}$ classes, e 4 professores, em duas escolas de Benguela. Para a recolha de dados usaram-se questionários e entrevistas, bem como guião de observação de aulas. Os resultados globais apontam para as potencialidades positivas da implementação da aula oficina no contexto educativo angolano contanto que se atendam às especificidades dessa realidade.

Fundado em preocupações acerca da avaliação em História, Lagarto ${ }^{11}$ desenvolveu um estudo que pretendia compreender como professores do $3 .^{\circ}$ ciclo do ensino básico desenvolviam e avaliavam competências em História. O estudo empírico, de foro

\footnotetext{
${ }^{8}$ VERÍSSIMO, 2012.

${ }^{9}$ AFONSO, 2014.

${ }^{10}$ NGUNGUI, 2017.

${ }^{11}$ LAGARTO, 2017.
} 
qualitativo e seguindo as propostas da Grounded Theory, contou nas suas diferentes fases com 6 professores e 174 alunos. Para a recolha de dados procedeu-se à observação de aulas, bem como à utilização de entrevistas e questionários aplicados a professores e tarefas aos alunos. Os dados analisados permitem concluir que as tarefas que suscitam maiores desafios cognitivos de utilização de fontes e conceptualização da mudança podem ajudar os alunos a construir ideias mais sofisticadas.

A Educação Histórica em Portugal, ao longo dos primeiros anos do século XXI, reforçou o seu campo de saber com os diversos estudos de investigação realizados quer no âmbito de projetos de investigação financiados, quer em estudos de Mestrado e Doutoramento, quer na sua articulação com a formação contínua de professores e a Associação de Professores de História. Este percurso sustentado tem sido reconhecido cientificamente ao nível nacional e internacional, e várias são as parcerias de investigação e formação que se têm estreitado, destacando-se este diálogo com o Brasil, o Reino Unido, a Espanha e a Colômbia.

\section{A ASSOCIAÇÃO DE PROFESSORES DE HISTÓRIA}

A Associação de Professores de História (APH), fundada em 1981, como associação científico-pedagógica de professores de História de todos os ciclos e graus de ensino, tem como objetivos promover a formação contínua nas vertentes científica e pedagógico-didática, contribuir para a abertura de novos campos de experiência e inovação no ensino da História, desenvolver projetos de investigação que articulem a teoria e prática no âmbito da Educação Histórica, incentivar o questionamento e a articulação educativa com o Património, participar de forma interventiva no debate sobre Educação, através do contributo da História, proporcionar contactos e trocas de experiências entre professores e outros agentes ligados ao ensino da História e estabelecer uma rede de relações com outras associações e entidades nacionais e estrangeiras ligadas ao ensino da História ${ }^{12}$. Por isso, não é de estranhar o envolvimento da APH na divulgação da Educação Histórica, linha de investigação conduzida pelo Instituto de Educação da Universidade do Minho, sobretudo na primeira década de 2000, aquando da implementação do Currículo Nacional do Ensino Básico de $2001^{13}$, tanto através de formação contínua, como através de artigos nas suas publicações, especialmente na revista «O Ensino da História».

Logo em 1999, Isabel Barca coordenou e supervisionou cientificamente um projeto de investigação, desenvolvido na APH, sobre «Conceções de professores sobre o ensino da História», com o intuito de conhecer melhor as apropriações que os professores faziam das novas propostas para criar um plano de formação consonante com as suas necessidades e a intencionalidade teórica dos programas/currículos. Este projeto tocava

\footnotetext{
${ }^{12}<$ https://aph.pt/quem-somos/objetivos-e-historia/>.

${ }^{13}$ A reestruturação para o $3 .^{\circ}$ ciclo estava em experimentação nas escolas desde 1998 e o no secundário iniciar-se-ia em 2001; PORTUGAL. Ministério da Educação. DEB, 2001.
} 
de perto com a investigação de Olga Magalhães para o seu projeto de doutoramento focado na exploração das conceções de História dos professores.

O envolvimento da APH na Educação Histórica foi ainda potenciado pelo papel de Isabel Barca como membro do conselho consultivo e da mesa da Assembleia Geral desde os finais da década de 1990 e, posteriormente, como Presidente da mesma Associação em 2001-2003. Esse envolvimento manteve-se durante a Presidência de Helena Veríssimo (2003-2009), ampliando-se a divulgação de experiências de aprendizagem para o desenvolvimento das competências correlacionadas com a Educação Histórica, através da formação contínua de professores ou da dinamização de encontros e/ou jornadas desenvolvidos nas escolas, de norte a sul, como resposta às solicitações dos professores sobre a Reorganização Curricular do Ensino Básico e sobre os novos Programas de História do Ensino Secundário.

A Educação Histórica foi também divulgada nos congressos anuais da APH, que se constituíam como oportunidade de formação contínua para os professores de História. Vários especialistas nacionais e internacionais (Peter Lee, Lis Cercadillo, Olga Magalhães, Marília Gago, Helena Pinto e Helena Veríssimo, entre outros) aí proferiram palestras e conferências ou desenvolveram workshops, tendo alguns Congressos sido dedicados ao debate específico das propostas da Educação Histórica, numa perspetiva de interligação da teoria à prática docente a esta temática: «A Educação Histórica em debate» 2000, Lisboa e Porto; «A História é importante!» 2007, Coimbra; «História, que futuro?» 2009, Lisboa.

O programa específico da formação contínua desenvolveu-se, ao longo da primeira década do século XXI, sobretudo na modalidade de oficina, com o intuito de generalizar a metodologia da aula oficina e as estratégias de exploração das ideias prévias dos alunos e de formação de opinião na sala de História. Essas oficinas abarcaram temas como as competências essenciais em História, a dinâmica da aula oficina, a utilidade do saber histórico, a consciência histórica e as Metas de Aprendizagem (já em 2011), sendo da responsabilidade de Olga Magalhães, Marília Gago, Helena Veríssimo, Helena Pinto, Paula Marinho Sousa, Paula Dias e, mais recentemente, a partir de 2017/18, Mariana Lagarto. Neste tipo de formação, bastante frequentada durante alguns anos, esteve também envolvida, como não podia deixar de ser, Isabel Barca.

A revista «O Ensino da História» contribuiu também para a divulgação da Educação Histórica.

Logo em 1999, Isabel Barca é entrevistada sobre os fundamentos teóricos desta área do saber, destacando três vetores essenciais em Educação Histórica: «a construção progressiva de uma narrativa histórica aberta e problematizadora da vida; o contacto com fontes primárias e secundárias diversificadas; o exercício de uma atitude argumentativa 
que permita treinar a fundamentação de posições com base em critérios racionais» ${ }^{14}$. Barca reflete ainda sobre a importância do objetivismo crítico e do construtivismo para a criação de estratégias propícias ao desenvolvimento da cognição histórica, como a aula oficina, e para a compreensão da forma como os alunos atribuem significados aos conceitos e ao conhecimento histórico.

No número duplo 19-20 é publicada a comunicação de Isabel Barca ${ }^{15}$ no congresso «A Educação Histórica em debate» de 2000, sobre o sentido da História e do conhecimento numa sociedade em constante mudança, e sujeita aos desafios da globalização, mostrando como a Educação Histórica pode ajudar os alunos a tratar a explosão de informação atual e contribuir para potenciar a educação para a cidadania.

No número duplo 21-22, Barca reflete sobre o documento das Competências Essenciais em História - o Currículo Nacional ${ }^{16}$. Inspirando-se nos estudos de Lee e Ashby e Shemilt, propôs que os princípios de aprendizagem incidissem sobre as ideias prévias dos alunos, a variância do nível de elaboração de ideias históricas (mesmo entre alunos da mesma idade) e a especificidade da natureza do conhecimento histórico, nomeadamente a sua provisoriedade. A competência de «compreensão histórica» devia ser equacionada nas dimensões de temporalidade e espacialidade e de contextualização.

No número duplo 23-24, dedicado à discussão do novo paradigma educacional proposto pela Reorganização Curricular do Ensino Básico, destaca-se o dossiê dedicado à «seleção de conteúdos» onde, a par de um artigo de José Machado Pais da DEB, encontramos as participações de Isabel Barca e de elementos da sua equipa de investigação histórica: Júlia Castro, Marília Gago e Ana Catarina Simão. Os artigos destas especialistas apresentam sólida fundamentação epistemológica na Educação Histórica para ancorar a seleção de conteúdos e as novas metodologias de ensino da História, reforçando a importância de uma formação contínua de qualidade para produzir aprendizagens significativas, tanto em alunos como nos professores. Castro ${ }^{17}$ apresenta uma experiência com alunos de $90^{\circ}$ ano para mostrar como os alunos entendem o que é importante em História, ou seja, sobre a significância histórica, desafiando os professores a criar tarefas que estimulem a compreensão crítica do passado, mas que permitam também pensar o presente e o futuro.

Na lógica de motivação dos professores para a mudança de paradigma e, sobretudo para a aceitação de que os alunos mais novos também pensam em História, Gago ${ }^{18}$ apresenta uma experiência com alunos de $5 .^{\circ}$ e $7 .^{\circ}$ anos de escolaridade em que estes comparam versões diferentes de uma narrativa histórica, mostrando que, com uma

\footnotetext{
${ }^{14}$ BARCA, 1999: 6.

${ }^{15}$ BARCA, 2001.

${ }^{16}$ BARCA, 2002a.

${ }^{17}$ CASTRO, 2002.

${ }^{18}$ GAGO, 2002.
} 
metodologia adequada, os alunos revelam um pensamento histórico sofisticado. Ainda no campo do trabalho de fontes com interpretações diversas, Simão ${ }^{19}$ chama a atenção dos professores para os cuidados a ter na seleção de recursos, nomeadamente em tarefas com alunos mais novos, para evitar que se redunde em situações de relativismo cético, que não contribuem para uma intervenção de qualidade dos jovens na sociedade. Finalmente, Barca ${ }^{20}$ apela a uma abertura de espírito na seleção de conteúdos curriculares, que considere a sua significância para a sociedade e para os jovens, devendo-se ter em atenção princípios epistemológicos referentes a um conhecimento atualizado e critérios de consistência científica. Assim, a ideia de uma História assente num passado de progressão linear, de narrativa única (muitas vezes reduzido a listagem de factos) deve ser abandonada para dar lugar a uma História que valorize a diversidade de perspetivas e que, por isso, possa implicar o abandono de uns conceitos em favor de outros que facilitem a compreensão da informação crescente num mundo em mudança.

Nos números 27-28 e 29 Helena Veríssimo discute, no âmbito da Educação Histórica, a utilidade da História, as vantagens da aprendizagem ativa e da utilização de fontes históricas, nomeadamente nos exames nacionais (reportando-se ao modelo que entrou em vigor em 2005).

$\mathrm{Na}$ coleção de cadernos pedagógicos-didáticos da APH foram ainda publicadas experiências de aprendizagem com alunos de $6 .^{\circ}$ e de $9 .^{\circ}$ anos de escolaridade relativas ao projeto de investigação «Formar opinião na aula de História», desenvolvido ao longo da década de 1990 e culminando em 2000, com o apoio da Fundação Calouste Gulbenkian. Essas experiências implicavam o trabalho da multiperspetiva sobre um tema tão controverso como a guerra colonial.

\section{BIBLIOGRAFIA}

AFONSO, Maria Isabel (2014) - O papel do manual de História no desenvolvimento de competência: um estudo com professores e alunos do ensino secundário. Braga: Universidade do Minho. Tese de doutoramento. Disponível em <http://hdl.handle.net/1822/34606>.

BARCA, Isabel (1999) - Entrevista com Isabel Barca (conduzida por Luís Santos e M. ${ }^{a}$ Amélia Agra). «O Ensino da História», n. ${ }^{\circ}$ 15. Lisboa: Associação dos Professores de História, p. 5-11.

(2001) - A Educação Histórica na sociedade de Informação. «O Ensino da História», vol. 21/22. Lisboa: Associação dos Professores de História, p. 35-42.

(2002a) - Competências e cognição em História. «O Ensino da História», vol. 21/22. Lisboa: Associação dos Professores de História, p. 36-37.

(2002b) - Conteúdos de História: Difícil é seleccioná-los! «O Ensino da História», n. ${ }^{0} 23 / 24$. Lisboa: Associação dos Professores de História, p. 29-32.

BARCA, Isabel; BASTOS, Maria Cristina; CARVALHO, Jorge Brandão (1998) - Formar Opinião na Aula de História - Uma Experiência Pedagógica sobre a Guerra Colonial. Lisboa: Associação dos Professores de História.

\footnotetext{
${ }^{19}$ SIMÃO, 2002.

${ }^{20}$ BARCA, 2002.
} 
BARCA, Isabel; GAGO, Marília (2000) - De pequenino se aprende a pensar: Formar opinião na aula de História e Geografia de Portugal. Lisboa: Associação de Professores de História. (Cadernos Pedagógico-Didácticos; 23).

CASTRO, Júlia (2002) - Na encruzilhada das Competências Específicas em História - as questões da significância histórica. «O Ensino da História», n. ${ }^{\circ}$ 23/24. Lisboa: Associação dos Professores de História, p. 17-21.

(2006) - A Interculturalidade e o Pensamento Histórico dos Jovens. Braga: Universidade do Minho. Tese de doutoramento.

GAGO, Marília (2001) - Concepções dos alunos acerca da variância da narrativa histórica - um estudo com alunos dos anos iniciais do $2^{\circ}$. e $3 .^{\circ}$ ciclos do ensino básico. Braga: Universidade do Minho. Dissertação de mestrado.

(2002) - Os alunos de 5. ${ }^{\circ}$ e 7..$^{\circ}$ anos são competentes perante diferentes versões do passado? «O Ensino da História», n. ${ }^{\circ}$ 23/24. Lisboa: Associação dos Professores de História, p. 21-24.

(2007) - Consciência histórica e narrativa na aula de História: concepções de Professores. Braga: Universidade do Minho. Tese de doutoramento. Disponível em <http://hdl.handle.net/1822/6752>. (2018) - Consciência histórica e narrativa na aula de História: conceções de Professores. Porto: CITCEM; Ed. Afrontamento.

LAGARTO, Mariana (2017) - Desenvolver e avaliar competências em História: um estudo com professores do $3 .^{\circ}$ ciclo do ensino básico. Braga: Universidade do Minho. Tese de doutoramento. Disponível em $<$ http://hdl.handle.net/1822/48700>.

MAGALHÃES, Olga (2002) - Concepções de História e de Ensino de História. Um estudo no Alentejo. 1.a ed. Lisboa: Colibri; CIDEHUS. 1 vol.

NGUNGUI, Angelina (2017) - Construir conhecimento histórico em contexto angolano: um estudo em torno de uma experiência de "aula oficina". Braga: Universidade do Minho. Tese de doutoramento. Disponível em <http://hdl.handle.net/1822/45763>.

PORTUGAL. Ministério da Educação. DEB (2001) - Currículo Nacional do Ensino Básico - Competências Essenciais. Lisboa: DEB.

PINTO, Helena (2011) - Educação histórica e patrimonial: conceções de alunos e professores sobre o passado em espaços do presente. Braga: Universidade do Minho. Tese de doutoramento. Disponível em $<$ http:// repositorium.sdum.uminho.pt/handle/1822/19745>.

(2016) - Educação histórica e patrimonial: conceções de alunos e professores sobre o passado em espaços do presente. Porto: CITCEM.

SIMÃO, Ana Catarina Gomes (2002) - Que História ensinar? «O Ensino da História», n. 23/24. Lisboa: Associação dos Professores de História, p. 24-28.

(2007) - A construção da evidência histórica: concepções de alunos do 3. ${ }^{\circ}$ ciclo do ensino básico e secundário. Braga: Universidade do Minho. Tese de doutoramento. Disponível em <http://hdl.handle. net/1822/7116>.

VERÍSSIMO, Maria Helena (2012) - A Avaliação de Competências Históricas através da Interpretação da Evidência: um Estudo com Alunos do Ensino Secundário. Braga: Universidade do Minho. Tese de doutoramento. Disponível em <http://hdl.handle.net/1822/28672>. 



\section{III \\ CONTRIBUTOS DE DOUTORAMENTOS}





\title{
PENSAMENTO HISTÓRICO DE CRIANÇAS, JOVENS E PROFESSORES: UM OLHAR INTERPERSPETIVADO ACERCA DA EXPLICAÇÃO-NARRATIVA HISTÓRICA
}

\author{
MARÍLIA GAGO*
}

Resumo: O pensamento histórico é um ato de pensamento, de interpretação, de compreensão contextualizada realizada pelo ser humano. Dray' afirma que toda a explicação histórica ocorre necessariamente a partir de uma perspetiva que, em algum sentido histórico, é relativa e carregada de valores. Neste sentido, apresenta uma teoria interperspetival e, nesta visão, o diálogo crítico entre diversas perspetivas constitui a materialização da História.

Os estudos pioneiros desenvolvidos por Dickinson e Lee ${ }^{2}$, Ashby e Lee ${ }^{3}$, e Shemilt ${ }^{4}$ da «Escola de Londres», serão a origem da Investigação em Educação Histórica. Em Portugal, na década de 1990, esta área de saber foi disseminada, na Universidade do Minho, destacando-se alguns dos vários trabalhos de Barca ${ }^{5}$. Aprender História faz sentido se houver a articulação entre a Epistemologia da História, a Educação-Cognição Situada e a Investigação. As crianças e os jovens devem experienciar «o fazer História», e deste modo, a História faz sentido(s), é vicariante e pode ser libertadora, pois alarga/amplia a conceção do que é o ser humano ${ }^{6}$. Imerso neste debate propõe-se um olhar interperspetivado acerca de estudos em Investigação em Educação Histórica acerca do modo como crianças, jovens e professores de História pensam a narrativa histórica e a explicação histórica, realizados em momentos distintos e com participantes de contextos diferenciados - Lee ${ }^{7}$, Barca $^{8}$ e Gago .

Parece poder-se afirmar que crianças e jovens dispõem de ferramentas cognitivas que Ihes permitem operar com conceitos meta-históricos, bem como a necessidade de se repensar a formação de professores. Neste sentido, é fulcral debater e operacionalizar educacionalmente as questões relacionadas com a Epistemologia do conhecimento social, de modo a promover a reflexão do educador de História acerca da sua responsabilidade face aos perfis de ideias de alunos, em termos de literacia histórica e, consequentemente, da consciência histórica e social desenvolvida, que os ajudarão a orientar a sua vida prática e as suas decisões. Este caminho de desenvolvimento progressivo de literacia histórica e consciência histórica deve ser ancorado num olhar interperspetivado em que o pensamento e conhecimento histórico de cada um ingresse na pluralidade das inúmeras perspetivas que dialogam criticamente e se reconhecem reciprocamente.

Palavras-chave: Investigação em educação histórica; Narrativa histórica interperspetivada; Explicação histórica; Literacia histórica; Consciência histórica.

\footnotetext{
* CITCEM; Universidade do Minho. E-mail: mgago@ie.uminho.pt.

${ }^{1}$ DRAY, 1991.

${ }^{2}$ DICKINSON \& LEE, eds., 1978.

${ }^{3}$ ASHBY \& LEE, 1987.

${ }^{4}$ SHEMILT, 1980

${ }^{5}$ BARCA, 1996; BARCA, 2000.

${ }^{6}$ RÜSEN, 2016.

${ }^{7}$ LEE, 1984; LEE, 1996.

${ }^{8}$ BARCA, 1996; BARCA, 2000.

${ }^{9}$ GAGO, 2012; GAGO, 2018.
} 
Abstract: Historical thinking is an act of thinking, of interpretation, of a contextualized understanding carried out by human beings. Dray ${ }^{10}$ states that all historical explanation necessarily takes place from a perspective that, in some historical sense, is relative and linked with values. In this sense, it presents an interperspectival theory and, in this view, the critical dialogue between different perspectives constitutes the materialization of History.

The pioneering studies developed by Dickinson and Lee ${ }^{11}$, Ashby and Lee ${ }^{12}$, and Shemilt ${ }^{13}$ of the "School of London», will be the origin of Research in History Education. In Portugal, in the 1990s, this area of knowledge was disseminated at the University of Minho, highlighting some of the various works of Barca ${ }^{14}$. Learning History makes sense when exists articulation between Epistemology of History, Education-Situated Cognition and Research. Children and young people must experience "making History", and in this way, History makes sense(s), is vicarious and can be liberating, as it widens/magnifies the conception of what the human being is ${ }^{15}$. Immersed in this debate, we propose an interperspective of various History Education about the way children, young people and history teachers think about historical narrative and historical explanation, carried out at different times and with participants from different contexts — Lee ${ }^{16}$, Barca $^{17}$ and Gago ${ }^{18}$.

It seems to be possible to state that children and young people have cognitive tools that allow them to operate with meta-historical concepts, as well as the need to rethink teacher education. In this sense, it is crucial to debate and operationalize educationally the issues related to the History Epistemology, in order to promote the reflection of the History educator about his responsibility vis-à-vis the students' ideas profiles, in terms of historical literacy and, consequently, of historical and social consciousness, which will help them to guide their practical life and their decisions. This path of progressive development of historical literacy and historical consciousness must be anchored in an interperspectivated vision in which the historical thought and knowledge of each one enters into the plurality of the innumerable perspectives that critically dialogue and recognize each other.

Keywords: Historical Education Research; Interperspectivated historical narrative; Historical explanation; Historical literacy; Historical consciousness.

A História permite ler e reconstruir a realidade - passado, presente e cenários possíveis - , a partir de várias perspetivas que complexificam o modo como fazemos sentido da vida e, consequentemente, permite uma orientação temporal num horizonte mais alargado e profundo.

Este quadro de conceptualização da História reconstruída e multiperspetivada pautou o quadro de propostas da Educação Histórica. Considera-se que os estudos pioneiros de Dickinson e Lee ${ }^{19}$ e Ashby e Lee ${ }^{20}$, bem como de Shemilt ${ }^{21}$ da chamada

\footnotetext{
${ }^{10}$ DRAY, 1991.

${ }^{11}$ DICKINSON \& LEE, eds., 1978.

${ }^{12}$ ASHBY \& LEE, 1987.

${ }^{13}$ SHEMILT, 1980.

${ }^{14}$ BARCA, 1996; BARCA, 2000.

${ }^{15}$ RÜSEN, 2016.

${ }^{16}$ LEE, 1984; LEE, 1996.

${ }^{17}$ BARCA, 1996; BARCA, 2000.

${ }^{18}$ GAGO, 2012; GAGO, 2018.

${ }^{19}$ DICKINSON \& LEE, eds., 1978.

${ }^{20}$ ASHBY \& LEE, 1987.

${ }^{21}$ SHEMILT, 1980.
} 
«Escola de Londres», foram o núcleo a partir do qual as ideias foram disseminadas. Em Portugal, ao longo da década de 1990 assistimos à disseminação deste quadro teórico e prático, nomeadamente na Universidade do Minho - licenciatura em História e Ciências Sociais e Mestrado em Supervisão Pedagógica e Metodologia do Ensino da História, destacando-se alguns dos vários trabalhos de Barca ${ }^{22}$. Esta disseminação teve, depois, ainda mais fôlego, ao longo da primeira década do século XXI com os vários estudos dos Projetos de Investigação Consciência histórica: teoria e práticas I e II. As propostas desta área de saber defendiam que aprender História faz sentido se houver a articulação entre a Epistemologia da História, a Educação-Cognição Situada e a Investigação, abandonando-se uma abordagem do processo de ensino-aprendizagem focalizada apenas no conteúdo substantivo da História. Assim, para podermos ter alguma oportunidade de desafiar a aprendizagem dos alunos é necessário conhecermos o modo como pensam historicamente e com que ideias lidam acerca da História (cognição situada). Neste sentido, é necessário investigar o pensamento histórico de crianças, jovens e professores para poder criar momentos de aprendizagem que os desafiem e potenciem o desenvolvimento do seu pensamento histórico.

Imersa em todo este quadro de teoria e prática, desde as aprendizagens da licenciatura passando-se pela prática em estágio supervisionado e continuando o percurso académico em investigação em educação histórica ao longo de mestrado, doutoramento e pós-doutoramento, o destino estava traçado - sem ter estranhado, entranhou-se a Investigação em Educação Histórica. O diálogo entre a Epistemologia da História, a Educação-Cognição Situada e a Investigação revelavam-se desafios constantes e insaciáveis. A cada resposta encontrada muitas outras questões emergiam - a provisoriedade das respostas impele-nos continuamente a investigar e a articular teoria e prática na procura de sentido(s) que permita(m) uma orientação temporal mais complexa, mais dialogante, mais humana.

A História como conhecimento tem por objeto de estudo a ação humana passada, interpretando-a através da evidência histórica, de forma a explicar o agir do ser humano no, e ao longo do tempo. Existe uma necessidade de descobrirmos o que pensavam os nossos antepassados e porque o pensavam, interpretando os indícios de que dispomos. Neste processo de interpretação faz-se uma tentativa, pelo menos de forma implícita, de se compreender e explicar um acontecimento rastreando as suas relações intrínsecas e localizando-os no seu contexto. Assim, a História tem como característica inerente enfatizar a importância da interpretação no fazer história, sendo deste modo impossível falar-se em conclusões históricas únicas, pois ela é encarada como uma construção. Atualmente, a História é reconhecida como uma reconstituição do pensamento passado no espírito do historiador. Assim, todo o presente possui um passado próprio, e qualquer

\footnotetext{
${ }^{22}$ BARCA, 1996; BARCA, 2000.
} 
reconstituição deste é uma reconstituição do passado a partir deste presente, ou seja, é o passado percebido aqui e agora. Neste sentido Dray ${ }^{23}$ afirma que dois historiadores trabalhando exatamente com as mesmas evidências históricas podem chegar a resultados diferentes, porque a sua interpretação que será materializada numa narrativa histórica irá atribuir diferentes pesos explicativos e assim, a interpretação pode divergir atendendo aos fatores e motivos considerados como relevantes para a explicação de uma dada situação. Assim, a evidência histórica que emerge do questionamento aos vestígios permite a interpretação e explicação da realidade, e expressa-se narrativamente. Realça-se que o processo de inferência histórica não é um processo exclusivo do conhecimento do passado. Muito do conhecimento sobre o presente também não é fornecido pela participação direta ou testemunhável presencialmente, antes é veiculado de forma indireta. Existe acesso a uma dada informação, a uma dada realidade presente, por meio de evidências indiretas. Com este argumento, não tem sentido o ceticismo da não possibilidade do conhecimento do passado por este ser mediatizado através de evidência ou conhecimento indireto, já que ele se processa à semelhança da maior parte do conhecimento do presente. Salienta-se que a interpretação, a explicação e a narrativa histórica não são entendidas, aqui, como expressão da simples opinião do autor. $\mathrm{O}$ facto de se afirmar que a narrativa histórica é a face material da interpretação de quem quer conhecer, do historiador, significa que se entende a História como uma reconstrução do pensamento da ação humana do passado com base na evidência; esta conceção não é semelhante à que considera a História como produto da opinião do historiador, que é tendencialmente subjetiva, arbitrária e gratuita. Embora possa ser uma opinião fundamentada, respeitando racionalidade, plausibilidade e inteligibilidade, pelo facto de ser uma pura opinião subjetiva, do foro do livre-arbítrio e sem suporte de evidência, abre caminho ao ceticismo e à não preocupação com a objetividade.

A objetividade em História pensada num quadro de objetividade perspetivada em linha com o realismo crítico funda-se num sistema interconectado de várias perspetivas. Isto é, torna-se necessário experienciar o processo vicariante de construir a História naturalmente multiperspetivada procurando-se no criticismo mútuo desenhar uma narrativa explicativa interperspetivada.

O pensamento histórico é um ato de pensamento, de interpretação, de compreensão contextualizada realizada pelo ser humano. Deste modo, dentro da mesma linha e segundo Dray ${ }^{24}$, toda a explicação histórica ocorre necessariamente a partir de uma perspetiva, a qual, em algum sentido histórico, é relativa e carregada de valores. Dray $^{25}$ apresenta uma teoria interperspetival e, nesta visão, o diálogo crítico entre diversas perspetivas constitui a materialização da história objetiva. Esta consiste no

\footnotetext{
${ }^{23}$ DRAY, 1980.

${ }^{24}$ DRAY, 1991.

${ }^{25}$ DRAY, 1991.
} 
próprio sistema de perspetivas, em que operam/dialogam diferentes perspetivas sociais, podendo, assim, atingir-se a objetividade.

Partilhando-se este quadro da Epistemologia da História surge a questão como e porquê aprender História. Acerca da importância de aprender História relembra-se Lee ${ }^{26}$ :

É quase "ridículo» perguntar qual é a utilidade da História ou porque é que se deve aprender História. Se o nosso conhecimento do mundo presente nunca é um conhecimento «instantâneo» e traz consigo conceções substantivas do passado, então ser-se historicamente ignorante é tão-só ser-se ignorante ${ }^{27}$.

Na linha da Educação Histórica, a aprendizagem das crianças e dos jovens deve assentar no diálogo entre os conceitos meta-históricos, próprios da ciência histórica (evidência, narrativa, explicação, tempo-mudança...), e a história substantiva da realidade em estudo. Mas, este diálogo deve ser experienciado, ou seja, as crianças e os jovens devem ser desafiados com tarefas assentes na interpretação de fontes históricas diversas, de modo a criarem evidência histórica que lhes permita tecer uma explicação contextualizada expressa narrativamente. Em suma, as crianças e os jovens devem experienciar "o fazer História», e deste modo, a História faz sentido(s), é vicariante e pode ser libertadora pois alarga/amplia a conceção do que é o ser humano ${ }^{28}$. Mas, como afirma Barca ${ }^{29}$, é necessário

conhecer como os jovens constroem as suas ideias históricas não só no plano substantivo mas também e, sobretudo, no plano das ideias de segunda ordem [meta-históricas].

ligar a teoria à prática, isto é, não prescrever apenas em estilo retórico o que os professores devem fazer e ainda não fazem em sala de aula, mas sim trabalhar com eles na tarefa de fazer melhor.

conhecer o mundo conceptual dos agentes educativos - o aluno, em primeira instância - porque só se pode mudar conscientemente aquilo que se conhece.

fazer da História um saber estruturante para os jovens, usável (versus saber inerte), para uma melhor orientação temporal na vida pessoal e social ${ }^{30}$.

O professor pensado como um investigador social tem de conhecer as ideias prévias dos alunos, quer em termos substantivos quer meta-históricos, para podermos

\footnotetext{
${ }^{26}$ LEE, 1984.

${ }^{27}$ LEE, 1984: 4.

${ }^{28}$ RÜSEN, 2016.

${ }^{29}$ BARCA, 2019.

${ }^{30}$ BARCA, 2014: 88 .
} 
ter alguma oportunidade para as desafiar e promover o desenvolvimento do pensamento das crianças e dos jovens. Assim, a aprendizagem histórica é pensada como uma reorientação cognitiva que pode transformar a forma de ver o Mundo promovendo-se forma(s) mais complexa(s) na tomada de decisão e no agir ${ }^{31}$. A História como uma compreensão em desenvolvimento que impulsiona o conhecimento da realidade em qualquer segmento temporal. Como propõe Rüsen ${ }^{32}$, a consciência histórica, que se expressa narrativamente formando e enformando a identidade, permite a orientação temporal - do eu/nós a ir sendo.

Esta visão de História transformativa articulada com uma educação histórica humanista remete-nos para a necessidade de, para além de atendermos à multiperspetiva que assenta em ideias de diferença e pluralidade, debatermos onde fica a ideia de togetherness como membros de uma mesma sociedade? ${ }^{33}$ Ou seja, é necessário um novo conceito que vá para além de ideias de exclusivismo e discriminação no sentido do desenvolvimento de uma consciência histórica mais sofisticada em linha com ideia da unidade na Humanidade - dignidade humana, promotora de compreensão interperspetivada $a^{34}$. Assim, parece ser fundamental ensinar e aprender a «Ser-se um ser Humano» ${ }^{35}$, à

luz do novo humanismo [...] a valorização e o reconhecimento da humanidade e dignidade do outro, de outras culturas, etnias, identidades de gênero e condições sociais, implica na compreensão das diferentes narrativas advindas de diferentes experiências históricas ${ }^{36}$.

Imerso neste debate, propõe-se um olhar interperspetivado acerca de estudos em Investigação em Educação Histórica acerca do modo como crianças, jovens e professores de História pensam a narrativa histórica e a explicação, realizados em momentos distintos e com participantes de contextos diferenciados - $\mathrm{Lee}^{37}$, Barca ${ }^{38}$ e Gago ${ }^{39}$.

Lee $^{40}$ discute se é possível, ou não, falar-se de uma progressão de ideias dos alunos sobre conceitos de segunda ordem (meta-históricos) como explicação. No CHATA Project focalizou a seguinte questão: Porque é que diferem as narrativas sobre a mesma história, ou seja, investigou as ideias dos alunos sobre como é possível que

\footnotetext{
${ }^{31}$ LEE, 2011.

${ }^{32}$ RÜSEN, 2016.

${ }^{33}$ RÜSEN, 2016

${ }^{34}$ DRAY, 1991.

${ }^{35}$ RÜSEN, 2016.

${ }^{36}$ NECHI \& SCHMIDT, 2015: 391.

${ }^{37}$ LEE, 1984; LEE, 1996.

${ }^{38}$ BARCA, 1996; BARCA, 2000.

${ }^{39}$ GAGO, 2012; GAGO, 2018.

${ }^{40}$ LEE, 1996.
} 
os historiadores produzam diferentes narrativas sobre a mesma passagem da História, tentando compreender como e até onde os alunos veem essas diferenças como importantes. Deste modo, procedeu à recolha de dados através de três tarefas de papel e lápis. Estas, para além de conterem informação histórica, tinham lado a lado, numa folha A4, duas estórias que diferiam no tom, tema e escala temporal, mas que ocupavam o mesmo espaço físico, e eram igualmente ilustradas e complementadas com um questionário. A amostra inicial deste estudo era constituída por 320 crianças com idades entre os 8 e os 14 anos, tendo sido entrevistadas cerca de 120 crianças. Face aos dados obtidos, Lee ${ }^{41}$ estabeleceu cinco níveis de progressão de ideias sobre o porquê da existência de diferentes narrativas históricas sobre uma mesma passagem da História, a saber:

1. The accounts are the same, the differences are only in the telling;

2. Differences are a result of problems in obtaining knowledge of the past;

3. The accounts are about different things, times or places;

4. Differences are a consequence of the accounts being written by different authors;

5. It is in the nature of accounts to be different from one another ${ }^{42}$.

As ideias colapsadas em cada um destes níveis partiam de ideias menos sofisticadas para um grau de elaboração maior.

Da análise dos dados, Lee $^{43}$ concluiu que emerge a ideia de que, com o avançar da idade, existe uma maior elaboração das ideias dos alunos acerca do porquê da existência de diferentes narrativas sobre a mesma passagem da História. Mas isto não significa, obrigatoriamente, que não tenha encontrado ideias tão sofisticadas como as que são alocadas ao nível de progressão Nature em crianças com 7 e 8 anos.

Em Portugal, e como trabalho pioneiro, surgiu o estudo de Barca ${ }^{44}$ sobre o pensamento histórico dos adolescentes acerca da provisoriedade da explicação histórica, expressa narrativamente e naturalmente multiperspetivada. Este estudo teve como população alvo os alunos com idades entre os 12 e os 20 anos a frequentar o 7. ${ }^{\circ}, 9 .^{\circ}$ e $11 .^{\circ}$ anos de escolaridade, de escolas da região do Minho de Portugal, num total de 320 alunos. Foram propostas a estes alunos tarefas constituídas por material histórico diversificado e multiperspetivado, acompanhado de um número de questões de diferente índole. Em sintonia com os pressupostos da investigação que se tem desenvolvido em cognição histórica situada, nomeadamente no Reino Unido, com os estudos de

\footnotetext{
${ }^{41}$ LEE, 1996.

${ }^{42}$ LEE, 1996: 14.

${ }^{43}$ LEE, 1996.

${ }^{44}$ BARCA, 1996; BARCA, 2000.
} 
Dickinson e Lee ${ }^{45}$, Ashby e Lee ${ }^{46}$, Shemilt ${ }^{47}$, entre outros, foram definidos cinco níveis de progressão das ideias dos alunos sobre um conceito de segunda ordem - a provisoriedade da explicação histórica - , a saber:

Nível 1. A «Estória» — [...] as "explicações» históricas como uma "estória» que narra descritivamente [...] focalizando na informação substantiva - «o que», e «como» acontece;

Nível 2. A explicação correcta - [...] uma descrição, as versões são ou não provadas pelos factos reais, certas ou erradas, com uma preocupação de procura da verdade. [...] Alguns alunos oscilam [...] não pode haver uma explicação correcta pois esta só poderia ser dada por uma testemunha ou agente histórico. [...];

Nível 3. Quantos mais factores melhor - as explicações são consideradas mais ou menos completas, [...] e são encaradas numa perspectiva agregacionista, em que a quantidade de factores é valorizada [...];

Nível 4. Uma explicação consensual - as explicações multicausais são consideradas relacionadas com a neutralidade [...]. A existência de diferentes explicações é considerada como decorrente de pontos de vista diferentes, os quais não são reconhecidos como legítimos em História. Observa-se uma oscilação entre a procura da explicação consensual, que necessariamente joga com a ideia de neutralidade absoluta, e a impossibilidade de não existir a «verdadeira explicação" pois não se pode escapar a um ponto de vista;

Nível 5. Perspectiva - a neutralidade já é vista, de forma emergente, como perspectivada. A perspectiva começa a ser reconhecida como característica da História, há um princípio emergente de objectividade crítica. As explicações diferem devido a critérios metodológicos específicos e são construídas segundo um modo narrativo ${ }^{48}$.

A investigadora concluiu que, na sua maioria, os jovens adolescentes portugueses conseguem ter uma ideia de provisoriedade das explicações, mas associada a uma noção de agregação de informação, lidando com noções de multicausalidade (colocando a tónica na questão da existência de mais ou menos fatores) e construindo as explicações segundo o modo causal ou modo narrativo (46\% das respostas dos alunos situava-se no nível 3 - «Quantos mais fatores melhor»). Contudo, alguns dos jovens adolescentes portugueses demonstraram possuir ideias bastante elaboradas sobre a provisoriedade da

\footnotetext{
${ }^{45}$ DICKINSON \& LEE, eds., 1978.

${ }^{46}$ ASHBY \& LEE, 1987.

${ }^{47}$ SHEMILT, 1980.

${ }^{48}$ BARCA, 2000: 140.
} 
explicação histórica, o que demonstra que estas podem e devem ser fomentadas para se desenvolverem numa perspetiva de progressão. Esses jovens cujas ideias se situam em níveis de progressão mais elaborados constroem as suas explicações de um modo narrativo, e não apenas como uma listagem de fatores, e questionam a objetividade histórica utilizando implicitamente critérios de neutralidade e de consistência explicativa. Realça-se, também, que o nível 1 «Estória», menos elaborado, foi observado apenas em alunos de $7 .^{\circ}$ e $9 .^{\circ}$ anos de escolaridade, e que o nível 5 «Perspetiva» surgiu apenas no $11 .^{\circ}$ ano de escolaridade. O nível 3 "Quantos mais fatores melhor» teve maior incidência no 9. ${ }^{\circ}$ e $11 .^{\circ}$ anos de escolaridade, e que o nível 4 «Uma explicação consensual» teve maior incidência no $7 .^{\circ}$ e $9 .^{\circ}$ anos de escolaridade ${ }^{49}$.

$\mathrm{O}$ estudo de $\mathrm{Barca}^{50}$ lança alguma luz em relação ao modo como os adolescentes portugueses podem entender a narrativa, se esta, epistemologicamente, for considerada de forma implícita como explicativa. Logo, ao estudar como os adolescentes pensam a provisoriedade da explicação histórica, por inerência exploram-se algumas ideias de narrativa, nomeadamente na sua dimensão explicativa.

$\mathrm{O}$ estudo de $\mathrm{Gago}^{51}$ pretendia compreender como é que crianças e adolescentes entre os 10 e os 13 anos pensavam a variância da narrativa histórica, ou seja, como explicavam a existência de várias narrativas históricas acerca da mesma realidade. Os alunos do $5 .^{\circ}$ e $7 .^{\circ}$ anos de escolaridade realizaram duas tarefas de papel e lápis, na linha do estudo de Lee ${ }^{52}$, acerca de um tema que é abordado ao longo da sua formação histórica "Os Romanos na Península Ibérica», embora tenham realizado a tarefa antes de o tema ter sido lecionado, e outro tema que não integra o programa curricular «O Vinho do Porto». As tarefas eram constituídas por material histórico de contextualização e por duas narrativas que tinham o tema geral em comum, eram ilustradas, ocupavam o mesmo espaço, mas eram distintas em termos de enfoque e escala temporal. As ideias dos alunos que emergiram no modo como resolveram as tarefas propostas deram origem a uma categorização em cinco perfis de ideias dos alunos. Estes perfis conjugavam os seguintes construtos: compreensão da mensagem, conceção de narrativa, o papel do historiador e conceção do passado. Assim, emergiram os seguintes perfis de ideias dos alunos, que se apresentam de forma sucinta:

\footnotetext{
${ }^{49}$ BARCA, 2019.

${ }^{50}$ BARCA, 1996; BARCA, 2000.

${ }^{51}$ GAGO, 2012.

${ }^{52}$ LEE, 1984; LEE, 1996.
} 


\section{Contar - A Estória:}

- Compreensão fragmentada da mensagem;

- Conhecimento substantivo;

- História contada;

- Passado está algures para ser contado ${ }^{53}$.

2. Conhecimento - Narrativa Correta:

- Compreensão restrita ou global;

- Conceito de narrativa:

- Narrativa correta/errada;

- Narrativa é uma cópia do passado;

- Historiador sabe mais ou menos - omite, distorce ou inventa;

- Passado conhecido através de diferentes vestígios ${ }^{54}$.

3. Diferença-Narrativa correta/Mais completa:

- Compreensão restrita ou global;

- Conceito de narrativa:

- Com mais ou menos factos;

- Narrativa correta ou errada;

- Historiador vê diferentes factos com ou menos viés;

- Passado, um todo de várias situações no tempo $0^{55}$.

4. Autor-Opinião ou narrativa consensual:

- Compreensão restrita ou global;

- Conceito de narrativa:

- Narrativa descritiva, explicativa;

- Narrativa interpretada;

- Opinião, fundamentada ou não, procura de consenso;

- Historiador interpreta a evidência, segundo a sua opinião;

- Passado é interpretado e construído através da evidência $a^{56}$.

\section{Natureza-Perspetiva}

- Compreensão global;

- Conceito de narrativa:

- Narrativa explicativa perspetivada;

- Historiador interpreta a evidência, segundo o seu ponto de vista opinião, natural e legítimo no conhecimento histórico;

- Passado é reconstruído através de respostas a questões feitas à evidência segundo os critérios históricos definidos pelo historiador ${ }^{57}$. 
Assim, os alunos do $5 .^{\circ}$ ano de escolaridade, na sua maioria, demonstraram ideias que foram colapsadas no perfil de ideias de alunos designado por "Conhecimento - Narrativa correta»; esta situação alterou-se no $7 .^{\circ}$ ano de escolaridade em que as ideias sugeridas demonstram um grau de relativa maior elaboração, a nível de «Autor - Opinião ou Narrativa consensual». Parece constatar-se que estes alunos do $7 .^{\circ}$ ano de escolaridade apresentam, no seu conjunto, um perfil de ideias mais elaborado do que os alunos de $5 .^{\circ}$ ano de escolaridade. Realça-se que, embora essas ideias mais elaboradas surjam com maior frequência em alunos num ano de escolaridade mais avançado, também são encontradas em alunos mais novos, o que sugere que não é a idade um fator determinante do grau de elaboração das suas conceções históricas. Esta conclusão apresenta-se em linha com as conclusões dos estudos de Lee ${ }^{58}$ e de Barca ${ }^{59}$.

Atendendo às ideias dos alunos portugueses acerca da variância da narrativa histórica de $\mathrm{Gago}^{60}$ e às ideias dos alunos britânicos do estudo de Lee ${ }^{61}$, parece poder-se concluir que não existem grandes diferenças do modo de pensar dos alunos destas duas nacionalidades. Ressalva-se que o estudo de Gago ${ }^{62}$ contou com um número menor de alunos, bem como com materiais semelhantes, mas não os mesmos usados por Lee ${ }^{63}$, mas mesmo assim parece poder-se afirmar que o modo de pensamento histórico dos alunos portugueses e dos alunos britânicos quanto à explicação da existência de diferentes narrativas é semelhante. Esta situação torna-se clara na medida em que os níveis de progressão definidos e apresentados por Lee ${ }^{64}$ têm semelhanças com os perfis de pensamento que emergiram das ideias dos alunos portugueses ${ }^{65}$.

Considerando as conclusões de $\mathrm{Barca}^{66}$, já referidas, os alunos participantes no seu estudo com menor idade ( $7 .^{\circ}$ e $9 .^{\circ}$ anos de escolaridade) apresentaram ideias que oscilam entre considerar a melhor explicação aquela que tem mais fatores e a procura de uma explicação consensual. No caso de Gago ${ }^{67}$, as crianças de 5. ${ }^{\circ}$ ano de escolaridade apresentaram ideias semelhantes quando justificam que a existência de diversas perspetivas se deve ao facto de os historiadores saberem mais ou menos acerca do passado; já os alunos de $7 .^{\circ}$ ano de escolaridade consideram que tal se deve ao ponto de vista do historiador, mas consideram que deveria procurar-se o consenso, isto é, promover-se uma narrativa consensual.

\footnotetext{
${ }^{58}$ LEE, 1984; LEE, 1996.

${ }^{59}$ BARCA, 1996; BARCA, 2000.

${ }^{60}$ GAGO, 2012.

${ }^{61}$ LEE, 1984; LEE, 1996.

${ }^{62}$ GAGO, 2012.

${ }^{63}$ LEE, 1984; LEE, 1996.

${ }^{64}$ LEE, 1984; LEE, 1996.

${ }^{65}$ GAGO, 2012.

${ }^{66}$ BARCA, 1996; BARCA, 2000.

${ }^{67}$ GAGO, 2012.
} 
Com base neste diálogo investigativo, partilha-se a ideia de Barca ${ }^{68}$ :

os alunos inquiridos tendem a desenvolver um pensamento explicativo, mas ainda muito assente no critério de "corta e cola» que valoriza a soma de fatores (COLLINGWOOD, 1946), mas sem preocupações de testar a validade das afirmações ou de ampliar o poder explicativo pela diversidade de fontes e cruzamento de perspetivas ${ }^{69}$.

Imersos neste quadro, surgiu uma nova questão: como pensarão os professores de História acerca da narrativa histórica em termos de epistemologia da História, bem como acerca do modo como a multiperspetiva pode ser usada na sala de aula de História. Na procura de respostas o foco de investigação norteado pela orientação de Isabel Barca deslocou-se para o estudo da consciência histórica e da narrativa histórica na aula de História, na perspetiva de professores de História e futuros professores de História ${ }^{70}$. Este novo estudo de investigação contou com 48 participantes, no estudo final, numa amostragem propositada segundo o critério de experiência profissional (alunos do $4 .^{\circ}$ ano de licenciatura, estagiários, professores com 3 a 10 anos de experiência, professores com mais de 10 anos de experiência), a lecionar no $3 .^{\circ}$ ciclo do ensino básico e no ensino secundário, e ligados aos setores público, privado e cooperativo. Este conjunto de 48 participantes dividiam-se em 12 elementos por estrato «profissional», havendo em cada estrato seis elementos da região norte do país (cidade de Braga) e seis da região sul (cidade de Évora). Para a recolha de dados foi construída uma entrevista com questionário interativo seguindo um guião que orientava o diálogo entre entrevistadora e entrevistados, incluía um conjunto de materiais históricos, nomeadamente narrativas históricas em linha com as tarefas papel e lápis utilizadas com o estudo de alunos ${ }^{71}$.

Analisados os dados das entrevistas, emergiram quatro perfis conceptuais acerca das conceções de professores sobre a relação da narrativa histórica e da consciência histórica. Os perfis que emergiram, numa lógica de elaboração progressiva de consciência histórica e ideia de História, foram os seguintes: 1. Passado substantivo; 2. Lições do passado; 3. Lições de um passado em evolução; 4. Continuidades e diferenças entre tempos ${ }^{72}$. A grande maioria dos participantes demonstrou ideias que foram colapsadas no perfil designado «Lições de um passado em evolução», cerca de 50\%, seguindo-se o perfil designado por «Lições do passado», cerca de 33,3\%. Uma vez que estes são os dois perfis de ideias com maior frequência, apresenta-se de seguida as suas características em termos do construto da narrativa histórica. Assim, o perfil designado por «Lições do

\footnotetext{
${ }^{68}$ BARCA, 2019.

${ }^{69}$ BARCA, 2019: 114.

${ }^{70}$ GAGO, 2007; GAGO, 2018.

${ }^{71}$ GAGO, 2001; GAGO, 2012.

${ }^{72}$ GAGO, 2018.
} 
passado» colapsa ideias de professores e futuros professores de História relativamente à narrativa histórica que se caracterizam por

o foco da atenção é colocado ao nível de autoria, conceptualizada como ponto de vista, e não como a opinião de autor. [...] Ao nível da utilidade da História no quotidiano, emerge a ideia de procurar ultrapassar a divergência entre pontos de vista procurando-se a coesão e o consenso.

Parece reconhecer-se, de forma emergente, que os alunos podem apresentar diferentes ideias e níveis de sofisticação de pensamento, mas a referência a esta diversificação é justificada com base em estádios de desenvolvimento definidos pela faixa etária em que se inscrevem os alunos ${ }^{73}$.

Já o perfil de ideias designado por «Lições de um passado em evolução» aponta para ideias mais sofisticadas:

A existência de diferentes narrativas é considerada como legítima e fruto de diferentes perspetivas sobre a realidade histórica. Considera-se necessário perscrutar qual é a perspetiva mais válida, e é dado especial relevo ao contexto de produção e ao autor da narrativa histórica, desejando-se a imparcialidade numa perspetiva ideal de neutralidade absoluta. Com base nestes argumentos, vê-se o consenso como um desvio da própria História, sendo por isso inaceitável. Para a construção da aprendizagem, aponta-se a utilização das diferentes perspetivas, procurando que se explicitem semelhanças e diferenças de cada uma delas, procurando-se através da contextualização de produção compreender a sua validade ${ }^{74}$.

Assim, os professores e futuros professores de História consideram a existência de múltiplas narrativas como fruto de diversos contextos, nomeadamente de produção, que devem ser analisadas e discutidas com os alunos, embora sob propostas sobretudo de cariz positivista (procurando-se a verdade, a imparcialidade neutral e o consenso).

Estas conceções de professores e futuros professores de História aproximam-se dos resultados obtidos com os estudos realizados entre crianças e jovens, já apresentados ${ }^{75}$. Parece existir entre professores e alunos um pensamento histórico em linha com uma conceção da História como única e neutral, procurando-se a objetividade através do consenso. Neste sentido:

\footnotetext{
${ }^{73}$ GAGO, 2018: 185.

${ }^{74}$ GAGO, 2018: 194.

${ }^{75}$ LEE, 1984; LEE, 1996; BARCA, 1996; BARCA, 2000; GAGO, 2001; GAGO, 2012.
} 
Torna-se urgente estimular o uso da interpretação e da argumentação de versões diversificadas da História, em aula, de forma a criar efetivamente um pensamento mais analítico e aberto à consideração do que é diferente $e^{76}$.

No estudo de $\mathrm{Gago}^{77}$, a identidade expressa pela escolha de símbolos de identidade foi, também, perscrutada, uma vez que indicia a consciência histórica dos participantes. Assim, através de um item de escolha múltipla que pedia a valoração entre 1 e 7, os participantes tinham de valorizar os diferentes símbolos de identidade propostos - entre os mais convencionais como a língua, a bandeira e o hino, passando pelas caravelas e o cravo vermelho, até símbolos menos convencionais como o bacalhau com todos, o vinho do Porto e o fado. Através de vários testes estatísticos conclui-se que

a importância máxima (correspondente a 7) foi atribuída apenas à bandeira, hino, cravo vermelho, língua e vinho do Porto. No caso do símbolo «língua», 50\% dos participantes atribuíram-lhe a importância máxima da escala; à bandeira, 25\% dos participantes atribuíram-lhe também o máximo de importância; ao hino, 25\% dos participantes atribuíram-lhe mais do que 6 na mesma escala ${ }^{78}$.

Estas opções de símbolos de identidade parecem demonstrar um pensamento de cariz nacional arreigado às especificidades e, à exceção da língua, no que nos diferencia do «Outro», consonante com uma perspetiva conservadora.

E, mais uma questão surgia: os alunos portugueses que escolhas fariam em termos de símbolos de identidade, seriam semelhantes ou distintas?

Nesta senda de constante indagação e Investigação em Educação Histórica, inscrito no Projeto de Investigação designado por Consciência Histórica: teoria e práticas (II), coordenado por Isabel Barca, e no âmbito de pós-doutoramento de Marília Gago, entre outras questões que faziam parte da tarefa 4 desse projeto, propôs-se a mesma questão acerca de símbolos de identidade ${ }^{79}$ a alunos de $9 .^{\circ}$ ano de escolaridade. Para a seleção dos participantes utilizou-se uma amostra propositada e heterogénea, em que 127 alunos de escolas do norte, centro e sul de Portugal, de escolas privadas e públicas, participaram. Estes alunos eram $51,2 \%$ do género masculino e $48,8 \%$ do género feminino com uma média de idades de 14,6 anos e uma classificação média à disciplina de História de nível 3,6 (em 5).

Os alunos participantes neste estudo na sua valoração de símbolos de identidade foram ainda mais convencionais. Assim, os símbolos escolhidos com maior valoração

\footnotetext{
${ }^{76}$ BARCA, 2019: 117.

${ }^{77}$ GAGO, 2018.

${ }^{78}$ GAGO, 2018: 223.

${ }^{79}$ GAGO, 2018.
} 
foram, de forma decrescente: a bandeira, o hino e a língua (com valores de moda de 7, 6 e 5 respetivamente). Os símbolos menos escolhidos foram, de forma crescente, os seguintes: bacalhau, cravo vermelho, caravelas, vinho do Porto e fado. Com base em testes estatísticos realizados conclui-se que existem diferenças estatisticamente significativas entre a valoração atribuída ao símbolo de identidade bandeira. Assim, os alunos a frequentarem as escolas do norte de Portugal atribuem uma valoração mais elevada do que os alunos das escolas do centro e sul de Portugal. Cruzando-se estas conclusões com as de $\mathrm{Gago}^{80}$ parece ser possível afirmar-se que os alunos, à semelhança dos professores e futuros professores de História, demonstram um pensamento de cariz nacional arreigado ao que nos diferencia consonante com uma perspetiva conservadora/tradicional $^{81}$, em linha com o que é afirmado por Pais ${ }^{82}$, que aponta que os jovens portugueses demonstram de forma ténue uma identidade «supranacional e europeia».

\section{ALGUMAS CONSIDERAÇÕES}

Tendo presente que os estudos propostos para este olhar interperspetivado se desenvolveram principalmente dentro de uma metodologia qualitativa descritiva em linha com as propostas da Grounded Theory ${ }^{83}$, e que no seu seguimento levaram a abordagens quantitativas, poder-se-ão tecer algumas linhas norteadoras que dão robustez ao campo de Investigação em Educação Histórica, relativamente à explicação-narrativa.

Parece poder-se afirmar que crianças e jovens dispõem, em potência, de ferramentas cognitivas que lhes permitem operar com conceitos meta-históricos, isto é, com conceitos inerentes à própria ciência histórica. Estas ferramentas, se já existem, devem necessariamente ser desenvolvidas progressivamente, tendo em vista uma complexificação no domínio da cognição histórica. Partilham-se as ideias de Barca ${ }^{84}$ :

Dentro do quadro de diagnóstico conceptual, há que atender também à constrangimentos na aprendizagem que poderão transformar-se em desafios. Por exemplo, há indícios de que o pensamento histórico de alunos e de professores em Portugal [...] assume contornos explicativos, o que é positivo; mas em simultâneo tende aceitar a explicação consensual sem reconhecimento de que a divergência faz parte da natureza humana e, por isso, também deve fazer parte da História [...]. Exige assim repensar a nível da formação histórica dos professores esse modelo de entender a História, que não é já compatível com os avanços epistemológicos e até mesmo com a vivência numa sociedade aberta ${ }^{85}$.

\footnotetext{
${ }^{80}$ GAGO, 2018.

${ }^{81}$ RÜSEN, 2017.

${ }^{82}$ PAIS, 1999.

${ }^{83}$ STRAUSS \& CORBIN, 1990.

${ }^{84}$ BARCA, 2019.

${ }^{85}$ BARCA, 2019: 124.
} 
Considera-se que atendendo ao quadro conceptual da narrativa histórica e os perfis de consciência histórica manifestados pelos futuros professores e professores de História se deverá repensar a formação de professores. Urge debater e operacionalizar educacionalmente as questões relacionadas com a Epistemologia do conhecimento social. Neste sentido, a promoção da reflexão docente de forma viável e frutuosa deve ser um percurso a ser construído entre professores de História e educadores/formadores de professores de História, isto é, entre a escola e o ensino superior, visando o contínuo crescimento profissional de forma transformadora. Esta dimensão encontra-se interligada com a necessidade de articular a formação inicial e contínua, as questões curriculares, os debates teóricos e operacionalizações educativas, uma profissionalidade docente transformadora-democrática, com o repensar dos perfis de profissionalidade de educadores de História capazes de responder com qualidade dinâmica aos novos desafios.

Realça-se a necessidade de promover entre os educadores a reflexão sobre a Investigação em Educação Histórica. Neste sentido, a reflexão do educador de História acerca da sua responsabilidade face aos perfis de alunos, em termos de literacia histórica e, consequentemente, consciência histórica e social, que os ajudarão a orientar a sua vida prática e as suas decisões, deve ser uma das principais preocupações nos diferentes níveis de ensino. Que em processo se tente desenhar os meios que possam contribuir e potencializar as competências históricas, de modo que se pense no futuro relacionando -o com vários presentes/passados. Neste sentido, se pretendemos a promoção de perfis mais elaborados, o ensino-aprendizagem da História tem de ser norteado por conceções meta-históricas, que contemplem elementos disciplinares. Atendendo ao novo quadro curricular português norteado pelas Aprendizagens Essenciais e o Perfil do Aluno à Saída da Escolaridade Obrigatória, urge implementar na sala de aula de História experiências de aprendizagem que permitam ser-se historicamente competente. Em linha com o que Barca ${ }^{86}$ propõe:

Ser historicamente competente hoje, implica:

- saber «ler» fontes históricas diversas - com suportes diversos, com mensagens diversas;

- saber confrontar as fontes nas suas mensagens, nas suas intenções, na sua validade;

- saber seleccionar as fontes, para confirmação e refutação de hipóteses (descritivas e explicativas);

- saber entender - ou procurar entender - o «Nós» e os «Outros», nos seus sonhos e angústias, nas suas grandezas e misérias, em diferentes tempos, em diferentes espaços;

- saber levantar novas questões, novas hipóteses a investigar - o que constitui, afinal, a essência da progressão do conhecimento ${ }^{87}$.

\footnotetext{
${ }^{86}$ BARCA, 2001; BARCA, 2004.

${ }^{87}$ BARCA, 2004: 134-135.
} 
A Educação Histórica impele-nos continuamente para a indagação e a articulação da Epistemologia da História, da Educação-Cognição Situada assente na Investigação. Urge compreender a História como uma forma de ver o Mundo e conceber o valor da História per se, isto é, que a História fomenta o pensamento independente e o respeito pelo ser humano, em linha com uma sociedade que se pauta pela democracia, mas não estando a História ao serviço de uma cidadania. Estas ideias devem ser concretizadas, operacionalizadas numa sala de aula aberta ao fluir de ideias, a várias possibilidades de resolução de problemas, onde a democracia não seja apenas um «ideal» a ser perseguido, mas sim uma experiência concreta que sirva como uma orientação para a vida.

Este caminho de desenvolvimento progressivo de literacia histórica e consciência histórica procura que exista um olhar interperspetivado em que o pensamento e conhecimento histórico de cada um ingresse na pluralidade das inúmeras perspetivas que dialogam criticamente e se reconhecem reciprocamente.

\section{BIBLIOGRAFIA}

ASHBY, Rosalyn; LEE, Peter (1987) - Children's concepts of empathy and understanding in history. In PORTAL, Christopher, ed. - The History Curriculum for Teachers. London: The Falmer Press, p. 62-88.

BARCA, Isabel (1996) - Adolescent students' ideas about provisional historical explanation. Londres: University of London. $\mathrm{PhD}$ thesis.

(2000) - O Pensamento Histórico dos Jovens: Ideias dos adolescentes acerca da provisoriedade da explicação histórica. Braga: CEEP/Universidade do Minho.

(2001) - Ser-se historicamente competente. Disponível em <http://www.aph.rcts.pt/inicio.html>. [Consulta realizada em 24/10/2001].

(2004) - Aula Oficina: do Projecto à Avaliação. In BARCA, Isabel, org. - Para uma Educação Histórica com Qualidade: Actas das IV Jornadas Internacionais de Educação Histórica. Braga: CIEd/Universidade do Minho; Instituto de Educação e Psicologia/Universidade do Minho, p. 131-144.

(2014) - Consciência histórica de jovens: identidade, mudança em História e Sentidos para vida. «Cadernos de Pesquisa: Pensamento educacional», vol. 9, n. ${ }^{\circ}$ 21, p. 86-107.

(2019) — Investigar em educação histórica em Portugal: opções metodológicas. «Educar em Revista», vol. 35, n. ${ }^{\circ} 74$, p. 109-126.

DICKINSON, Alaric; LEE, Peter, eds. (1978) - History teaching and historical understanding. London: Heinemann.

DRAY, William (1980) - Perspectives on history. London: Routledge and Kegan Paul.

(1991) - Comment. In VAN DER DUSSEN, W. J.; RUBINOFF, Lionel, eds. - Objectivity, method and point of view: Essays in the philosophy of history. Leiden: E. J. Brill, p. 170-190.

GAGO, Marília (2001) - Concepções dos alunos acerca da variância da narrativa histórica - um estudo com alunos dos anos iniciais do $2 .^{\circ}$ e $3 .^{\circ}$ ciclos do ensino básico. Braga: Universidade do Minho. Dissertação de mestrado.

(2007) - Consciência histórica e narrativa na aula de História: concepções de professores. Braga: Universidade do Minho. Tese de doutoramento.

(2012) - Pluralidade de Olhares: Construtivismo e Multiperspetiva no Processo de Aprendizagem. Moçambique: EPM-CELP.

(2018) - Consciência histórica e narrativa na aula de História: conceções de professores. Porto: CITCEM; Edições Afrontamento. 
LEE, Peter (1984) - Why learn History? In DICKINSON, Alaric; LEE, Peter; ROGERS, P., eds. — Learning History. London: Heinemann Educational, p. 1-20.

(1996) - «None of us was there». Children's ideas about why historical accounts differ. Paper presented at the Triennal Nordic Conference on History Didactics. Tampere, Finland. Junho.

(2011) - Historical literacy and transformative history. In PERIKLEOUS, Lukas; SHEMILT, Denis, ed. The future of the past: why history education matters. Nicosia: UNDP-ACT; AHDR, p. 129-168.

NECHI, Lucas Pydd; SCHMIDT, Maria Auxiliadora (2015) - História de uma escolha, escolha de uma história: estudo exploratório sobre elementos do novo humanismo e a formação da identidade histórica. Anais Eletrônicos. Goiás, vol. 15, n. ${ }^{\circ}$ 2, p. 384-403.

PAIS, José M. (1999) - Consciência Histórica e Identidade. Os jovens portugueses num contexto europeu. Oeiras: Celta Editora.

RÜSEN, Jörn (2016) - Algumas ideias sobre a interseção da meta-história e da didática da história. «História Hoje», vol. 5, n. ${ }^{\circ}$ 9. São Paulo, p. 159-170.

(2017) - Evidence and Meaning. London: Berghan Books.

SHEMILT, Denis (1980) - History 13-16 Evaluation Study. Edinburgh: Holmes McDougall.

STRAUSS, Anselm; CORBIN, Juliet (1990) - Basics of qualitative research: Grounded theory, procedures and techniques. Thousand Oaks, CA, US: Sage Publications, Inc. 


\title{
NA CHARNEIRA DE UMA EDUCAÇÃO HISTÓRICA
}

\author{
ANA CATARINA GOMES LAGE LADEIRA SIMÃO*
}

Resumo: O Ensino da História constitui uma área de estudo sobre a qual se têm debruçado vários investigadores portugueses. Nesta área de estudos, também denominada de Cognição Histórica Situada, iniciada em Portugal por Isabel Barca, procura-se conhecer como os alunos constroem o seu conhecimento histórico e, consequentemente, a sua consciência histórica - finalidade intrínseca da Educação Histórica. Procura-se compreender como os alunos aprendem a História e que ideias de segunda ordem constroem e mobilizam. Estas ideias de segunda ordem estão sempre subjacentes ao conhecimento histórico e merecem um enfoque especial nas investigações portuguesas que surgiram com o desenvolvimento do polo de investigação da Universidade do Minho, dirigido por Isabel Barca.

A minha investigação de doutoramento, orientada por Isabel Barca, enquadra-se na linha de cognição histórica situada e visa ser um contributo para o estudo das estratégias adotadas pelos alunos para construírem as suas sínteses históricas e do modo como se relacionam com as fontes históricas. Nomeadamente, procura compreender como é que os alunos do ensino básico e do ensino secundário entendem a evidência histórica e perceber até que ponto a forma como entendem a evidência Ihes permite construírem inferências históricas fundamentadas e multiperspetivadas.

Estas investigações foram essenciais para uma mudança lenta, mas concertada, no Ensino da História. Na disseminação dos resultados das investigações têm sido fulcrais as Jornadas Internacionais de Educação Histórica que agora completam vinte anos de existência. Paralelamente, a formação inicial e continuada de professores por investigadores nesta área comparece como a forma mais rápida e profícua de divulgar os resultados da investigação e de permitir que estes provoquem inflexão nas práticas docentes.

Palavras-chave: Educação histórica; Consciência histórica; Evidência; Formação de professores.

Abstract: The teaching of History is an area of study that various Portuguese investigators have diligently researched. In this area of study, also known as Cognitive Historic Situated investigative studies, developed in Portugal by Isabel Barca, one pretends to know how the students construct their historical knowledge and consequently their historical consciousness - the intrinsic determined end of Historical Education. The teaching of History seeks to explore the knowledge of how the students learn History, the second order ideas that construct and mobilize. These second order ideas are always subject to historical knowledge and deserve a special focus in the Portuguese investigations that emerge with the development of the University of Minho research center, directed by Isabel Barca.

My PhD investigation done under Isabel Barca's orientation falls in line with historical situated cognition and aims to be a contribution to the study of the strategies adopted by students to build their historical overviews and how they relate to historical sources. In particular, it seeks to understand how students of primary and secondary schools understand the historical evidence and to what extend their understanding of the evidence allows them to build historical inferences supported and multiperspectivated.

These investigations have been essential to effect a slow but concerted change in the teaching of History. The International Historical Education Trips, that complete twenty years of existence, have supported the dissemination of the investigative results. Parallel to this, the initial and continuous

\footnotetext{
* Escola Básica e Secundária Dr. Vieira de Carvalho; Escola Superior de Educação do Porto; CITCEM. E-Mail: ana. catarina.simao@hotmail.com.
} 
formation of the teachers by the investigators appears to be the fastest and most profitable form to disseminate the results of the investigation and to permit changes in the teacher's practices.

Keywords: Historical education; Historical consciousness; Evidence; Teacher formation.

\section{INTRODUÇÃO}

Foi com um duplo sentimento de honra e grande responsabilidade que aceitei o convite que me foi feito para integrar este livro que visa homenagear, à data da realização das Vigésimas Jornadas Internacionais de Educação Histórica, Isabel Barca uma investigadora que tem marcado definitivamente os rumos do Ensino da História no nosso país, trabalhando colaborativamente com outros polos de investigação a nível internacional, tornando-se, assim, o nome incontornável nesta área da investigação.

Iniciei a minha carreira na Faculdade de Letras, onde me licenciei em História, no Ramo Educacional.

Desde o primeiro momento que a História ciência me cativou, e no percurso denso e longo da licenciatura fui percebendo que tanto a investigação na ciência como o Ensino da História me eram muito caros. Não sendo possível conciliar em sede de licenciatura as duas vias, decidi que, mal terminasse a licenciatura, prosseguiria os meus estudos fazendo mestrado, de forma a, por um lado, manter o vínculo com a universidade que tanto me custava abandonar, por outro lado, desenvolver competências de investigação, estudando mais de três mil fólios que não tinham ainda sido trabalhados, bem guardados na área de reservados da Biblioteca Municipal do Porto. Escolhi a Idade Moderna por ser a minha preferida e estudei as confrarias corporativas do Porto, por achar que assim prestaria um duplo serviço à História e à Cidade. Se a História nos ajuda a dar sentido ao que nos rodeia, a cidade guardava em si tantos vestígios de uma História que devia ser feita e a que prestei o meu contributo.

Este foi um tempo de exercitar as minhas competências em paleografia e de aprofundar os meus conhecimentos na História da Cultura e das Mentalidades, que foram, ao longo da minha licenciatura, as minhas disciplinas favoritas.

Terminado o mestrado em 1997 e começando a pensar iniciar o doutoramento na mesma área, comecei a achar redundante e, se tinha aprendido mais sobre investigação em História, como era meu desejo e me parecia incontornável para consolidar a minha formação, o Ensino da História pareceu-me a partir daquele momento o investimento mais profícuo para a minha carreira de professora.

Assim, após ouvir pela primeira vez a Professora Isabel Barca, num Congresso promovido pela APH, que se realizou no Porto, onde falou de Aula-Oficina, percebi que era a linha de investigação que protagonizava em Portugal que desejava aprofundar e que poderia enriquecer grandemente a minha formação inicial. Foi assim que deixei a minha «casa-mãe» e ingressei em doutoramento na Universidade do Minho. 
Não foi nada difícil decidir o tema sobre o qual me iria debruçar. Logo nas primeiras reuniões em que debatemos a questão, em sede de investigação de doutoramento, as fontes e uso das fontes em sala de aula emergiram como a temática mais pertinente a aprofundar, dedicando-me assim, desde o primeiro momento, ao estudo do conceito de evidência e à compreensão de como os alunos de $3 .^{\circ}$ ciclo e Ensino Secundário construíam a evidência em sala de aula.

\section{BREVE APRESENTAÇÃO DA LINHA DE INVESTIGAÇÃO EM EDUCAÇÃO HISTÓRICA}

Na última década do século XX, à semelhança do que ocorreu no Reino Unido, nomeadamente com o Projeto Chata - Concept of History and Teaching Approaches 7-14 e com o Projeto History 13-16, coordenados por Peter Lee e Denis Shemilt ${ }^{1}$, teve início uma linha de investigação em Educação Histórica liderada por Isabel Barca, que procurou perceber como é que os nossos alunos compreendem e aprendem História. Iniciaram-se estudos de natureza empírica, construídos indutivamente com base em dados empíricos, que, observando os alunos em contexto de sala de aula, procuraram, de forma sistemática e com todo o rigor que a metodologia de investigação nos impõe, perceber as ideias históricas de alunos e dos professores de História.

Esta nova linha de investigação criava também uma ponte entre as mais recentes reflexões epistemológicas em História e as reflexões em educação histórica, ligando a academia às escolas numa relação dialética, contrariando a perspetiva isolacionista do saber escolar em relação às produções do saber da «História Ciência» e da Filosofia da História.

Os estudos que desde então foram levados a cabo, em sede de mestrado, doutoramento e pós-doutoramento, debruçaram-se sobre as ideias dos alunos e visaram perceber como é que os alunos construíam a sua aprendizagem e como é que essa aprendizagem seria potenciada partindo dos conhecimentos prévios dos alunos, através da metodologia de Aula-Oficina, com o trabalho sistemático de fontes diversificadas no suporte, conteúdo e perspetiva, levando os alunos, à semelhança do que acontece com os historiadores, a questionarem as fontes e a construírem explicações fundamentadas a partir das mesmas, produzindo, para esse efeito, as suas próprias narrativas. Na senda de Rüsen ${ }^{2}$, pretende-se, através das narrativas que constroem, compreender os sentidos que dão ao passado e como interpretam o passado, entendem o presente e perspetivam o futuro.

Esta conceção construtivista, com foco na promoção de aprendizagens significativas e relevantes, inspirou-se em vários trabalhos levados a cabo no Reino Unido e

\footnotetext{
${ }^{1}$ ASHBY \& LEE, 1987; SHEMILT, 1980; SHEMILT, 1987.

${ }^{2}$ RÜSEN, 2001: 160.
} 
deu origem a um número considerável de estudos que, no esforço de conhecer como é que os alunos compreendem os conceitos inerentes à disciplina de História, procuraram inspirar mudanças práticas e objetivas no trabalho de sala de aula.

Esta nova linha de investigação estuda, a partir das narrativas dos alunos, conceitos de «segunda ordem» como explicação, empatia, evidência, tempo, mudança, causa, narrativa, significância, multiperspetiva, consciência histórica. Estes conceitos são estruturantes do pensamento histórico dos alunos e os estudos levados a cabo forneceram indicadores de progressão conceptual e permitiram concluir que esta não é nem linear nem invariante, mas apresenta oscilações que dependem muito das experiências de aprendizagem que lhes são proporcionadas.

Assim, em Portugal, na charneira desta linha, temos Isabel Barca, que, partindo do modelo de progressão conceptual proposto por Lee e Shemilt, levantou questões e suscitou reflexões académicas que procuraram suscitar uma mudança sustentada das práticas em sala de aula e nas práticas de avaliação de alunos. Neste sentido, as investigações que foram levadas a cabo no nosso país seguiram o modelo britânico referido, procurando não só identificar as ideias que os alunos apresentam, mas categorizá-las de forma sustentada, estabelecendo um modelo de categorização de análise das mesmas, sustentado por um quadro conceptual conseguido de forma empírica, através da análise sistemática de ideias apresentadas pelos alunos que viabilizaram estas investigações.

É convicção nesta linha de investigação em Educação Histórica que a condição para melhorar o conhecimento histórico dos nossos alunos passa obrigatoriamente pela exploração sistemática e empírica das ideias dos alunos e pelo trabalho sistemático de conceitos inerentes à natureza da História, abandonando conceções estanques que vinculam necessariamente o conhecimento do aluno à sua faixa etária e que condenam em sede de aula o trabalho de fontes com métodos e tarefas similares às utilizadas pelo historiador.

Procura-se ainda abandonar práticas de avaliação das ideias dos alunos com base no tudo ou nada, certo ou errado, completo ou incompleto e conhecer o nível conceptual dos nossos alunos para criar condições pedagógicas, através do uso e análise de fontes e de uma relação dialógica, de diagnosticar se a progressão conceptual se faz tanto a nível de «ideias substantivas» como a nível de ideias de «segunda ordem», de modo a construir de forma significativa a sua aprendizagem histórica e a sua consciência histórica. Rüsen ${ }^{3}$ acentua a aprendizagem da História como consciência humana a relacionar-se com o tempo para dar-lhe significado, adquirindo a competência de dar sentido ao tempo e desenvolvendo essa mesma competência.

${ }^{3}$ RÜSEN, 2010: 79. 


\section{O PAPEL DAS JORNADAS INTERNACIONAIS EM EDUCAÇÃO HISTÓRICA}

Em sede do meu doutoramento, integrei o grupo pioneiro desta linha de investigação, tendo colaborado na organização das primeiras e das segundas jornadas; apresentando comunicações nas sétimas e nonas jornadas e estando presente na maioria das restantes.

As jornadas foram, ao longo de vinte edições, um espaço privilegiado: 1) para receber em território português ou brasileiro investigadores internacionais da nossa linha de investigação da Educação Histórica, tendo a possibilidade de discutir trabalhos já publicados pelos mesmos e os resultados das suas pesquisas, bem como de conhecer as suas investigações em curso; 2) para divulgar investigações nacionais realizadas em sede de mestrado, doutoramento e pós-doutoramento, permitindo dialogar e reter contactos com os investigadores, e perceber melhor os desafios que os mesmos colocavam à comunidade científica e à prática docente; 3) constituíram também um momento único de discussão de pressupostos epistemológicos e de Filosofia da História, permitindo colocar em diálogo áreas do saber que tradicionalmente tiveram grandes dificuldades de diálogo e que neste contexto, e a convite de Isabel Barca ou Maria Auxiliadora Schmidt, quando as jornadas começaram a alternar-se entre Portugal e Brasil, passaram a dialogar e a enriquecer-se mutuamente.

As jornadas foram, como pude destacar, um espaço de diálogo que faltava entre a academia e a escola, entre os historiadores e os professores que no terreno intervêm no sentido da construção do conhecimento histórico e da consciência histórica dos nossos alunos, entre ambos e os que se debruçam nas difíceis questões da Epistemologia e da Filosofia da História. Nem as fronteiras dos gabinetes, nem as das diversas universidades que constroem esse saber em território nacional, nem as fronteiras nacionais, nem os preconceitos que mantinham estas áreas de saber isoladas resistiram ao apelo de encontro, de partilha e de diálogo encetado por Isabel Barca e que enriqueceu tanto a academia como a formação inicial e contínua de professores.

\section{BREVE RESENHA DE UM CONTRIBUTO NESTA LINHA DE INVESTIGAÇÃO}

O estudo empírico que realizei em sede de doutoramento, orientado por Isabel Barca, pretendeu compreender como é que alunos de $3 .^{\circ}$ ciclo e Ensino Secundário constroem a evidência histórica em sala de aula, ou seja, até que ponto a forma como entendem a evidência lhes permite construírem inferências históricas fundamentadas e multiperspetivadas. 
A evidência histórica é a base de todo o conhecimento histórico. E, a este respeito, Van Der Dussen ${ }^{4}$ afirma: «Excluding memories, which are no part of historical knowledge, all knowledge of the past is based on evidence.»

O uso da evidência é fulcral no ensino da História, pois é ela que permite a reconstrução dos acontecimentos do passado, seguindo critérios de uma objetividade intersubjetiva e não positivista. Lee $^{5}$ destaca:

School history cannot turn students into mini-professional historians, and it should not try, but it can begin to help them understand how historical claims are based on evidence, that explanations are not the same as singular factual statements, and that it is in the nature of history that there will be different accounts of the past, but that none of this means history is just a matter of opinion.

Neste estudo empírico, de natureza qualitativa que contou com uma amostra de cem alunos, escolheu-se adotar a proposta de definição do conceito de Evidência Histórica proposta por Ashby ${ }^{6}$ : «A Evidência Histórica situa-se entre o que o passado deixou para trás (as fontes dos historiadores) e o que reivindicamos do passado (narrativas ou interpretações históricas).»

Das respostas dos alunos emergiram seis níveis de progressão nas ideias dos alunos, no que respeita a este conceito estruturante do conhecimento histórico.

No nível um - Evidência como cópia do passado - o aluno entende que a fonte dá acesso direto ao passado e utiliza fragmentos de informação da fonte. Para os alunos deste nível, o papel do historiador é encontrar a fonte certa. Concebem o passado como garantido e fixo. Pensam na História como descoberta e não levantam questões de metodologia.

No nível dois - Evidência como informação - nota-se um progresso relativamente ao primeiro nível. O aluno já soma informação da fonte. Concebe o papel do historiador como encontrar a fonte certa e contá-la. O passado é algo fixo, tido por garantido e conhecido por alguma autoridade. É visto como se fosse presente. As questões de metodologia estão reduzidas a verdadeiro e falso.

\footnotetext{
${ }^{4}$ VAN DER DUSSEN, 1991: 155.

${ }^{5}$ LEE apud BARCA, 2000: 11.

${ }^{6}$ ASHBY, R. (2001) - Children's ideas on evidence. Porto: Universidade Portucalense. Comunicação apresentada no Congresso dos Professores de História.
} 
No nível três - Evidência como testemunho ou conhecimento - a fonte é vista como informação privilegiada a ser avaliada. Os alunos valorizam a observação direta, valorizam o agente histórico (fonte primária). O papel do historiador é descobrir as fontes certas. Emerge a noção de que deve criticá-las e avaliá-las. O passado é narrado, mal ou bem, por pessoas que viviam naquela época. A História é narrada a partir da avaliação das fontes, mas tem carácter definitivo. Em alguns alunos emerge a ideia de construção.

No nível quatro - Evidência como prova - emerge de forma simples a consciência de evidência. O papel do historiador é criticar fontes e somar «evidência». Elaborar a sua versão. Interpretar, mas não inferir. $\mathrm{O}$ passado é conhecido a partir da avaliação das fontes. Admitem a perspetiva em História, mas anseiam o consenso (perspetivismo como contingência da História que a diminui enquanto ciência). A História é vista como construção definitiva e consensual através de verificação/avaliação das fontes.

No nível cinco - Evidência Restrita - emerge a consciência de evidência. Os alunos fazem inferências a partir de uma só fonte. Consideram que o papel do historiador é construir o conhecimento histórico a partir da evidência. O ponto de vista é legitimo. O passado é interpretado e construído a partir das fontes. A História é a perspetiva do autor segundo critérios de objetividade perspetivada, admitem a (re)construção perspetivada.

No nível seis - Evidência em Contexto - os alunos apresentam consciência da historicidade da evidência. Emerge a consciência dos contextos. O papel do historiador é inferir a partir das fontes, construir a evidência em contexto. Infere para lá das fontes. O passado é interpretado/inferido e construído a partir da evidência em contexto. A História é concebida como a perspetiva do autor segundo critérios de objetividade perspetivada. (Re)construção perspetivada e provisória.

Observou-se maior incidência da amostra nos níveis intermédios - níveis 2, 3 e 4. O nível de progressão maioritário foi o nível dois no Ensino Básico e o quatro no Ensino Secundário. As ideias dos alunos do Ensino Básico situam-se, maioritariamente, entre os níveis 1 e 2 (66\% da amostra), as dos alunos do Ensino Secundário situam-se, sobretudo, entre os níveis 3 e 4 (75\% da amostra). No entanto, no nível 5 encontram-se respostas dos alunos do Ensino Básico ( $5 \%$ da amostra) e do Ensino Secundário (2\% da amostra). Apenas dois alunos do Ensino Secundário manifestaram ideias de Evidência em contexto (nível 6).

Uma das preocupações que nos levaram a focar a nossa reflexão em torno da evidência histórica e da sua construção em sala de aula foi a convicção de que o trabalho de interpretação de fontes em contexto de aula de História é deficitário e mal orientado. 
A fonte é usada de forma acrítica, sem gerar inferências, tantas vezes como mera ilustração, motivação ou acréscimo de informação, sem qualquer preocupação metodológica, de contextualização, de análise e de compreensão do seu contexto de produção.

O questionamento das fontes é algo próprio da ciência histórica e que deve ser uma constante no tratamento das temáticas substantivas. As fontes históricas devem ser trabalhadas pelos alunos de acordo com o conceito de Aula-Oficina, no sentido de construírem a evidência e mobilizarem conceitos de «segunda ordem» para concluírem acerca de informação substantiva.

$\mathrm{Na}$ conceção de momentos de aprendizagem significativa com fontes, é necessária uma boa seleção de fontes que devem ser diversificadas no seu estatuto, na sua linguagem e na mensagem.

Algumas questões do questionário que realizei no meu estudo empírico podem ajudar os docentes a desenhar, dentro do modelo de Aula-Oficina, momentos que potenciem a construção da evidência histórica. Assim, é pertinente levantar questões como: a) Por que razão achas que os documentos A e B não estão de acordo? b) Segundo o teu ponto de vista, quando os documentos não estão de acordo sobre um mesmo assunto serão úteis ou não para o historiador? Justifica a tua resposta. c) Há alguma razão que te leve a pensar que algum dos documentos - E ou $\mathrm{F}$ - possa não ser credível? Justifica a tua resposta.

No estudo empírico que realizei, constatei a dificuldade que os alunos de $3 .^{\circ}$ ciclo apresentavam na interpretação das fontes iconográficas, revelando níveis de desempenho muito baixos nas questões que as mobilizavam e raciocínios mais elaborados nas questões que mobilizavam as fontes escritas. Esta geração de alunos que está sempre a ser bombardeada com imagens revela dificuldade na interpretação e mobilização das mesmas para a construção do conhecimento histórico.

Outro dado empírico a destacar foi a preferência por fontes primárias, vistas como autoridades em relação às fontes secundárias, sem que para isso mobilizassem outras questões metodológicas.

Destacou-se, acima de tudo, uma acentuada vinculação ao paradigma de observação direta. A testemunha ocular é muito valorizada e o que diz é tido como certo. Quando colocados perante uma fonte ficcional - banda desenhada - os alunos tendem a validá-la automaticamente por encontrarem na fonte convergência com os seus conhecimentos prévios, ou a invalidá-la por a considerarem uma fonte não fidedigna, fazendo essa afirmação sem analisar o seu conteúdo.

Os alunos mostraram muita dificuldade em concluir acerca da razão da divergência das fontes, o que nos leva a pensar que as tarefas que lhes eram propostas regularmente não os confrontavam com esta realidade. É fundamental que os alunos entendam que a convergência e a divergência de informação das fontes são igualmente naturais e que consigam inferir a partir de fontes convergentes e divergentes. 
É importante que os alunos se questionem acerca da razão possível ou provável para a divergência das fontes. Este trabalho não pode continuar a ser adiado e deve ser começado muito cedo e ser progressivamente aprofundado. Mas é muito importante que ao trabalhar a História nesta perspetiva não passemos para os nossos alunos a ideia de relativismo no conhecimento histórico, mas levá-los a compreender as especificidades do conhecimento histórico - a sua incompletude, a sua provisoriedade, a sua objetividade perspetivada.

\section{CONCLUSÃO}

Hoje, graças à formação que me facultou a pioneira da Educação Histórica em Portugal, alterei radicalmente a forma como ensino, e a cada passo procuro fundamentação na investigação para informar a minha prática.

Como formadora de professores, procuro divulgar os resultados das investigações, fazê-los experimentar o modelo Aula-Oficina e planificar estratégias que potenciem um pensamento histórico mais elaborado.

Com a oportunidade de voltar ao ensino superior e agora ter um papel ativo na formação inicial de professores, tenho oportunidade de aumentar o impacto desta linha de investigação já tão consolidada e de desafiar estes novos professores para percursos investigativos que enriqueceram o seu trabalho e a comunidade científica da Educação Histórica.

Saibamos nós, e eles, honrar o esforço de quem antes de nós desbravou este caminho que nos permite formar melhor e de forma mais consciente os nossos alunos para esta sociedade plural e tão exigente.

\section{BIBLIOGRAFIA}

ASHBY, Rosalyn; LEE, Peter (1987) - Discussing the evidence. «Teaching History», n. ${ }^{\circ}$ 48. Londres: The Historical Association, p. 13-17.

BARCA, Isabel (2000) - O Pensamento Histórico dos Jovens: Ideias dos Adolescentes acerca da Provisoriedade da Explicação Histórica. Braga: CEEP/Universidade do Minho.

BARCA, Isabel; SCHMIDT, Maria Auxiliadora, org. (2009) - Educação Histórica: Investigação em Portugal e no Brasil. Actas das 5. ${ }^{a s}$ Jornadas Internacionais de Educação Histórica. Braga: CIEd/Universidade do Minho.

GARD, A.; LEE, Peter (1978) - Educational objectives reconsidered. In DICKINSON, Alaric; LEE, Peter, ed. - History teaching and historical understanding. Londres: Heinemann, p. 21-38.

RÜSEN, Jörn (2001) - A razão da História. Brasília: UniB. (2010) - Experiência, interpretação, orientação: as três dimensões da aprendizagem histórica. In RÜSEN, Jörn - Jörn Rüsen e o Ensino de História. Org. M. A. Schmidt, I. Barca, E. R. Martins. Curitiba: Editora da UFPR, p. 79-91.

SHEMILT, Denis (1980) - History 13-16 Evaluation Study. Edinburgh: Holmes McDougall. (1987) - Adolescent ideas about evidence and methodology in history. In PORTAL, Christopher, ed. The History Curriculum for Teachers. Londres: The Falmer Press, p. 39-61. 
SIMÃO, Ana Catarina Gomes (2007) - A construção da evidência histórica: concepções de alunos do $3 .^{\circ}$ ciclo do ensino básico e secundário. Braga: Universidade do Minho. Tese de doutoramento.

SIMÃO, Ana Catarina Gomes; BARCA, Isabel (2011) - A construção da evidência histórica e as metas de aprendizagem. In BARCA, Isabel, org. - Educação e Consciência Histórica na Era da Globalização. Braga: CIEd/Universidade do Minho; Lisboa: Associação de Professores de História, p. 63-76.

VAN DER DUSSEN, W. J. (1991) - The historian and his evidence. In VAN DER DUSSEN, W. J.; RUBINOFF, Lionel, eds. - Objectivity, method and point of view: essays in the philosophy of history. Leiden, The Netherlands: E. J. Brill, p. 154-169.

WINEBURG, Sam (1991) - Historical problem solving: A study of the cognitive processes used in the evaluation of documentary and pictorial evidence. «Journal of Educational Psychology», vol. 83, n. ${ }^{0}$ 1, p. 73-87. 


\title{
EDUCAÇÃO HISTÓRICA E PATRIMONIAL: PERCURSOS DE INVESTIGAÇÃO
}

\author{
HELENA PINTO*
}

\begin{abstract}
Resumo: O presente texto sintetiza um percurso de investigação em Educação Histórica que, em articulação com a Educação Patrimonial, se realizou, numa parte substancial, com a orientação e marca indelével de Isabel Barca.

Descrevem-se brevemente dois estudos de investigação, um no âmbito de Mestrado em Património e Turismo, e outro no âmbito do Doutoramento em Ciências da Educação. No primeiro caso, o estudo revelou que o contacto direto com o património possibilita aos jovens a expressão de um pensamento histórico sobre as alterações verificadas no património urbano, para além dos limites da sua educação escolar, familiar ou do meio local. No segundo estudo, mais aprofundado, procurou-se clarificar as relações entre Educação Histórica e Educação Patrimonial. Considerou-se que os dados recolhidos ao longo das várias fases do estudo poderiam contribuir para a construção de um modelo conceptual sobre a progressão de inferências históricas de alunos relativamente à interpretação de fontes patrimoniais e de tipos de consciência acerca da relação dialógica entre passado e presente.
\end{abstract}

Palavras-chave: Educação histórica; Educação patrimonial; Pensamento histórico.

Abstract: This text synthesises a research in History Education which, in conjunction with Heritage Education, has been carried out, in a substantial part, with Isabel Barca's guidance and indelible mark.

Two research studies are briefly described, one in the scope of a master in Heritage and Tourism, and the other in the scope of a PhD in Educational Sciences. In the first case, the study revealed that direct contact with heritage enables young people to express a historical thought about the changes in urban heritage, beyond the limits of their school, family or local environment education. In the second, more in-depth study, the relationship between Historical Education and Heritage Education was clarified. It was considered that the data collected during the various phases of the study could contribute to the construction of a conceptual model on the progression of pupils' historical inferences in relation to the interpretation of heritage sources and types of consciousness about the dialogical relationship between past and present. Keywords: History education; Heritage education; Historical thinking.

\section{INTRODUÇÃO}

A entrada da Educação Histórica e da sua «mãe portuguesa», Isabel Barca, no meu percurso académico, profissional e pessoal, fez-se a partir de 2001, através de um projeto e dissertação de Mestrado em Património e Turismo (U. Minho). Sendo licenciada em História pela Faculdade de Letras da Universidade do Porto, e aí tendo feito o estágio profissionalizante, foi o contacto, durante dez anos, com o património arqueológico em diversas campanhas de escavações no norte do país que me entusiasmou não só para uma prática letiva «diferente» nas minhas aulas de História com alunos de $3 .^{\circ} \mathrm{CEB}$ e do Ensino Secundário, mas também para o aprofundamento de uma pesquisa que

* CITCEM/U. Porto. E-mail: mhelenapinto@gmail.com. 
relacionasse as áreas do património e da educação. Era este o tema que pretendia para a dissertação de mestrado. O meu orientador, o Arqueólogo e Professor Francisco Sande Lemos, tendo estabelecido um primeiro contacto com a Educação Histórica, como palestrante convidado nas Primeiras Jornadas de Educação Histórica, que decorreram em 2000 na Universidade do Minho, propôs à Professora Isabel Barca a coorientação da minha dissertação - Guimarães, Centro Histórico: Património Educação. Assim começava uma "parceria» que se traduziu numa profunda aprendizagem e na criação de laços pessoais de amizade que se reforçaram nos anos seguintes, com o projeto Consciência Histórica: Teoria e Práticas II e, sobretudo, com o Doutoramento em Ciências da Educação, especialidade de Educação em História e Ciências Sociais, orientado desta vez apenas por Isabel Barca, entre 2008 e 2011, com a tese intitulada Educação Histórica e Patrimonial: conceções de alunos e professores sobre o passado em espaços do presente ${ }^{1}$.

A Educação Histórica continuou, e continua, em articulação com a Educação Patrimonial, a marcar a escrita de artigos científicos e publicações diversas, assim como a minha participação em congressos nacionais e internacionais, sendo de destacar as Jornadas Internacionais de Educação Histórica, realizadas e organizadas diversas vezes com a minha colaboração e, sempre, com a coordenação tutelar da Professora Isabel Barca.

Tendo regressado à Faculdade de Letras da Universidade do Porto desde finais de 2014, desta vez como Investigadora Integrada do CITCEM (Centro de Investigação Transdisciplinar Cultura, Espaço e Memória), onde foi publicada a versão revista da minha tese de doutoramento ${ }^{2}$, os nossos caminhos voltaram a encontrar-se, com a integração de ambas - assim como de outras investigadoras também orientadas por Isabel Barca, como a saudosa Isabel Afonso, Marília Gago, Mariana Lagarto e Ana Catarina Simão - no Grupo de Investigação «Educação e Desafios Societais», coordenado pelo Professor Luís Alberto Alves, onde se inclui não só a Educação Histórica, mas também a Educação Patrimonial.

\section{DA EDUCAÇÃO PELO PATRIMÓNIO À EDUCAÇÃO HISTÓRICA}

No estudo realizado em sede de Mestrado em Património e Turismo, em que se indagava sobre algumas das possibilidades de Educação Patrimonial através de atividades educativas relacionadas com o património num centro histórico ${ }^{3}$, procurou-se conhecer as conceções de crianças e adolescentes sobre o património em contexto de observação direta, através de um estudo descritivo, de natureza qualitativa, que assumiu

\footnotetext{
${ }^{1}$ PINTO, 2011.

${ }^{2}$ PINTO, 2016.

${ }^{3}$ PINTO, 2003.
} 
características exploratórias em termos de investigação sistemática neste domínio, em Portugal. Com este estudo empírico, pretendeu-se esclarecer as seguintes questões ${ }^{4}$ :

1. Quais as conceções de crianças e adolescentes sobre o património integrado no «Centro Histórico» de Guimarães?

1a. Que níveis conceptuais revelam num contexto de observação direta do património?

1b. Que fontes de conhecimento utilizam?

2. Quais as possibilidades de Educação Patrimonial suscitadas por uma experiência organizada de contacto com o património?

No que respeita às técnicas de investigação a utilizar neste estudo, tomou-se como ponto de partida a sua adequação ao desenho em processo, nomeadamente ao problema e questões de investigação, aos participantes e aos contextos de aplicação dos instrumentos. Assim, teve-se em consideração diversas técnicas utilizadas na investigação em Ciências Sociais e, mais especificamente, em Educação Histórica e Patrimonial: o questionário (proposta de um conjunto de tarefas escritas), a entrevista, como técnica exploratória, ou de seguimento, e, secundariamente, a observação direta (participante), apenas no sentido de obter informações que apoiassem a compreensão das situações observadas com o objetivo de apurar a construção dos instrumentos aplicados ao longo das fases do estudo. Por este motivo, essas últimas informações não foram objeto da análise de dados.

Para a recolha de dados, elaboraram-se instrumentos que foram aplicados numa experiência educativa - um percurso no centro histórico de Guimarães, com 35 participantes, crianças e adolescentes residentes na cidade, divididos em dois grupos: um dos 8 aos 11 anos e outro dos 12 aos 14 anos. Optou-se, neste estudo, por uma análise intensiva de uma amostra de trinta e cinco participantes ${ }^{5}$ (vinte participantes, no estudo final). Para a seleção da amostra, decidiu-se utilizar estas faixas etárias — dos 8 aos 14 anos de idade - como unidades de análise, por corresponderem a idades nas quais a Educação Patrimonial parece ter grande recetividade e que vai, também, ao encontro das intenções expressas nos currículos do Ensino Básico, assim como dos resultados de um estudo europeu ${ }^{6}$. Teve-se, ainda, em conta a literatura existente na linha de pesquisas sobre Cognição Situada em História, que aponta para a possibilidade de crianças (a partir dos 7-8 anos, pelo menos) e adolescentes darem sentido a situações multiperspetivadas e de

\footnotetext{
${ }^{4}$ PINTO, 2003.

${ }^{5}$ Concretizada em duas fases: o estudo-piloto, com seis participantes entre os 12 os 14 anos, num primeiro momento, e nove participantes entre os 8 e os 11 anos, num segundo momento; e o estudo final, com dez participantes de cada grupo etário, também em dois momentos.

${ }^{6}$ PAIS, 1999.
} 
incerteza, desde que se revistam de significado humano 7 . Por outro lado, a observação de jovens de duas faixas etárias permitiria constatar semelhanças e especificidades entre estes dois grupos na vivência de uma experiência idêntica.

Atendendo às características da experiência educativa pretendida, as técnicas aplicadas neste estudo empírico foram a observação naturalista, apoiada na audiogravação das intervenções orais dos participantes, convidados a partilharem com o grupo as suas perceções acerca dos edifícios observados e dos locais que iam percorrendo, as tarefas escritas propostas no instrumento de trabalho, o Guia «À Descoberta do Centro Histórico de Guimarães», progressivamente explorado por cada participante ao longo de um percurso por quatro áreas do centro histórico e um questionário preenchido individualmente no final da atividade, para avaliar o interesse suscitado pela experiência educativa.

Utilizou-se uma metodologia de análise de dados predominantemente qualitativa, que permitiu ensaiar um modelo de categorização, delineado por enunciados teóricos de Educação em Museus ${ }^{8}$ em cruzamento com estudos em Cognição Situada em História ${ }^{9}$, nomeadamente ${ }^{10}$ :

1. Verbalização partilhada com base na apreensão dos elementos observados e na experiência pessoal;

2. Verbalização partilhada com base na observação e na experiência pessoal, apresentando uma contextualização histórica restrita;

3. Reflexão criativa e personalizada, num exercício de síntese a acrescentar às características anteriores.

Os resultados deste estudo mostraram que a exploração educativa do património, de forma sistemática e fundamentada, pode contribuir para o desenvolvimento do pensamento histórico dos jovens, e estes podem atingir níveis conceptuais mais ou menos elaborados em relação ao património - acerca de acontecimentos e personalidades históricas, mudança e continuidade, reconstrução e preservação - sem uma relação absoluta com a faixa etária. Algumas crianças de 8 a 11 anos demonstraram desempenho adequado em tarefas idênticas às dos adolescentes entre 12 e 14 anos, embora uma reflexão criativa e personalizada, no nível definido como representativo de uma maior elaboração em termos de opinião pessoal fundamentada, tenha surgido sobretudo entre os adolescentes.

\footnotetext{
${ }^{7}$ COOPER, 1992; BARCA 2000; BARCA \& GAGO, 2000; LEE, 2001.

${ }^{8}$ AGUILLERA \& VILLALBA, 1998.

${ }^{9}$ LEE \& ASHBY, 2001; SHEMILT, 1987.

${ }^{10}$ PINTO, 2003.
} 
Este estudo ${ }^{11}$ revelou, ainda, que o contacto direto com o património possibilita aos jovens a expressão de um pensamento histórico sobre as alterações verificadas no património urbano, para além dos limites da sua educação escolar, familiar ou do meio local. No entanto, para tal não basta que os educadores apresentem propostas em termos prescritivos e impressionistas, pois a elaboração de materiais educativos, no plano metodológico ou noutro, exige um processo cuidadoso que atente na adequação de aspetos como a formulação de questões, as propostas de tarefas e a duração das atividades, e a avaliação dos materiais, permitindo experiências educativas com intervenientes de níveis etários diferentes, em contextos diversos. Foi nesse sentido que se prosseguiu para a investigação de doutoramento, já no âmbito mais específico das Ciências da Educação, mas continuando a cruzar os contributos da Educação Histórica e da Educação Patrimonial.

\section{CRUZANDO CAMINHOS NUMA INVESTIGAÇÃO DE DOUTORAMENTO}

Posteriormente, a investigação que se traduziu em tese de doutoramento ${ }^{12}$ propôs-se aprofundar a compreensão dos sentidos atribuídos por alunos e por professores a fontes patrimoniais na aprendizagem e no ensino de História. Seguindo uma linha de investigação em Educação Histórica que procura conhecer e compreender o pensamento histórico dos participantes, baseou-se numa metodologia predominantemente qualitativa, fazendo inferências das respostas dos participantes sobre diversos conceitos históricos ${ }^{13}$, de forma a esclarecer o problema central que se explorou neste estudo - De que forma alunos e professores de História interpretam a evidência de um sítio histórico?

Com vista a clarificar as relações entre Educação Histórica e Educação Patrimonial, foi necessário revisitar um debate teórico, enquadrado por diferentes perspetivas relativamente às conceptualizações de património, memória, identidade e de consciência histórica. Este enquadramento teórico implicou não só a articulação com a organização curricular existente em Portugal, nomeadamente no que respeita ao ensino e aprendizagem de História nos níveis básico e secundário, mas também com diversos exemplos de investigação empírica no âmbito da Educação formal ${ }^{14}$ e não formal - nomeadamente de educação em museus e em sítios históricos/arqueológicos - particularmente a pesquisa relacionada com a interpretação de vestígios patrimoniais. Formularam-se as seguintes questões de investigação, relativas a conceções de alunos e de professores ${ }^{15}$ :

\footnotetext{
${ }^{11}$ PINTO, 2003.

12 PINTO, 2011.

${ }^{13}$ ASHBY et al., 2005.

${ }^{14}$ BARCA, 2004.

${ }^{15}$ PINTO, 2011; PINTO, 2016.
} 
- Como usam os alunos de $7 .^{\circ}$ e de $10 .^{\circ}$ anos de escolaridade os sítios histó-ricos - espaços, edifícios e objetos com eles relacionados - enquanto evidência de um passado em mudança?

- Que tipo de pensamento histórico desenvolvem os alunos em ambiente de exploração direta do património?

- Que conceções acerca da exploração do património revelam os professores em contexto de atividades relacionadas com o uso de fontes patrimoniais, no âmbito do currículo escolar?

O processo investigativo compreendeu duas fases preliminares (exploratória e piloto), de ensaios, em termos empíricos, tendo em vista uma possível redefinição conceptual e o afinamento dos instrumentos e procedimentos de investigação, antes da implementação do estudo principal ${ }^{16}$. Procedeu-se à seleção da amostra, à clarificação dos procedimentos a utilizar para a recolha de dados e respetiva análise, enquadrada por literatura específica.

A atividade educativa consistiu num percurso com pontos de paragem para observação de objetos e edifícios selecionados no centro histórico de Guimarães, com base num instrumento elaborado para o efeito. Esse guião-questionário continha a proposta de um conjunto de tarefas escritas a realizar em cada um dos pontos de paragem e em contacto direto com objetos, edifícios ou locais históricos. As questões/tarefas propostas apresentavam grau de dificuldade crescente, sendo o terceiro item de maior exigência cognitiva, pois a pesquisa histórica procede de questões específicas, identificando o que se sabe, o que se pode supor e o que se quer saber ${ }^{17}$. A seleção das fontes patrimoniais a observar e interpretar atendeu a uma lógica de análise de património diversificado, relacionado com a Idade Média, mas tendo em conta a sua historicidade (até ao presente) em várias dimensões da vida em sociedade, nomeadamente pela sua ligação a grupos profissionais, a personalidades, a eventos ou situações de âmbito político-militar e religioso, ou social e económico (como os tanques de curtumes na «Zona de Couros»). Pretendia-se, ainda, ter em consideração a significância ${ }^{18}$ dessas fontes patrimoniais não só no âmbito da história local, mas também como microcosmos indiciador de aspetos da história nacional e, até,

\footnotetext{
${ }^{16}$ No estudo principal utilizou-se uma amostra participante constituída por 87 alunos, sendo 40 do $7 .{ }^{\circ}$ ano e 47 do 10. ${ }^{\circ}$ ano de escolaridade, e os professores de História/História da Cultura e das Artes dos sete grupos de alunos, que se inseriam em turmas heterogéneas no que diz respeito a área de residência (concelho). Os instrumentos de recolha de dados consistiram, no caso dos alunos, num questionário e num guião de entrevistas de seguimento para clarificação de respostas de alguns alunos (33 alunos, sendo 14 de $7 .^{\circ}$ ano e 19 alunos de $10 .^{\circ}$ ano de escolaridade) e, no caso dos professores (três de $7 .^{\circ}$ ano e quatro de $10 .^{\circ}$ ano, sendo um deles comum aos dois anos de escolaridade), num breve questionário aplicado previamente e posteriormente à atividade realizada com os alunos. Os dados foram sistematicamente recolhidos e analisados indutivamente, numa reflexão sustentada nas respostas dos alunos e dos professores aos respetivos instrumentos de pesquisa.

${ }^{17}$ COLLINGWOOD, 2001.

${ }^{18}$ CASTRO, 2006.
} 
europeia. A seleção de fontes diversificadas, a suscitar leituras sob vários ângulos, permitiria aos alunos terem uma ideia de conjunto, e não de objetos isolados, fragmentados ou descontextualizados, quando já não se encontram no espaço original ${ }^{19}$.

Considerou-se que os dados recolhidos ao longo das várias fases do estudo poderiam contribuir para a construção de um modelo conceptual sobre a progressão de inferências históricas de alunos relativamente à interpretação de fontes patrimoniais e de tipos de consciência acerca da relação dialógica entre passado e presente ${ }^{20}$. Este estudo assumiu um método de análise indutiva dos dados, por comparação constante, das respostas escritas ao guião-questionário e entrevistas de seguimento individuais, no caso dos alunos, e das respostas escritas aos questionários prévio e posterior à atividade, no caso dos professores. Para tal, utilizou-se ao longo das várias fases do estudo o método da Grounded Theory ${ }^{21}$ ou Teoria Fundamentada, no sentido de obter modelos de perfis conceptuais de alunos e de professores inspirados em literatura específica na linha de investigação em Educação Histórica e em alguns estudos de Educação Patrimonial, e construir consequentes tarefas a aplicar em contexto de aprendizagem situada.

No sentido de responder às duas primeiras questões de investigação, procurou-se construir gradualmente um modelo conceptual que organizasse as ideias dos alunos participantes segundo níveis de progressão quanto ao modo como concebiam o uso da evidência a partir de fontes patrimoniais e ao tipo de consciência que revelavam quanto à relação entre passado e presente, através da exploração de fontes patrimoniais. Dois construtos foram organizados em vários perfis conceptuais progressivamente sofisticados ${ }^{22}$ :

\section{Uso da evidência:}

- Alternativa;

- Inferência a partir de detalhes concretos;

- Inferência a partir de elementos relacionados com o contexto;

- Problematização.

\footnotetext{
${ }^{19}$ PINTO, 2011; PINTO, 2016.

${ }^{20}$ Paralelamente, e em articulação (respondendo à terceira questão de investigação), permitiria a construção de um modelo de padrões conceptuais de professores que sugerisse como entendem o uso de fontes patrimoniais em atividades de ensino e aprendizagem de História, e até que ponto estão conscientes da importância do uso dessas fontes segundo critérios metodológicos mais rigorosos, com vista ao desenvolvimento da compreensão histórica dos alunos, assim como da sua relação identitária com o património. Neste texto, apenas se inclui a análise referente aos alunos participantes no estudo principal.

${ }^{21}$ STRAUSS \& CORBIN, 1998.

${ }^{22}$ PINTO, 2011; PINTO, 2016.
} 


\section{Consciência histórica:}

- Consciência a-histórica;

- Consciência de um passado fixo;

- Consciência de um passado simbólico;

- Consciência histórica emergente;

- Consciência histórica explícita.

No que concerne ao "uso da evidência», bastantes alunos do $7 .^{\circ}$ ano $(53,3 \%)$, e também do $10 .^{\circ}$ ano $(41,4 \%)$ entenderam as fontes (escritas e patrimoniais) como provedoras diretas de informação, indiciando a ideia de que a fonte permite conhecer o passado tal como aconteceu. Predominaram as descrições reportando informação a partir de alguns elementos das fontes e as conjeturas que os alunos levantaram reportaram-se sobretudo a detalhes factuais.

No entanto, diversos alunos $\left(21,2 \%\right.$ do $7 .^{\circ}$ ano e $28,5 \%$ do $10 .^{\circ}$ ano $)$ pareceram já ter abandonado a noção de fonte como «relato», começando a olhar as fontes como um conjunto e não como fragmentos ${ }^{23}$. Ao longo do percurso e à medida que avançavam nas tarefas, estes alunos mostraram ganhar progressivamente mais confiança em lidar com as fontes como evidência ${ }^{24}$, interpretando-as em contexto a partir de um quadro analítico: descrição de mudanças, questionamento, formulação de conjeturas. Revelaram inferências pessoais, procedendo a uma contextualização da informação em termos sociais, culturais, políticos e económicos, relacionando-a com os seus conhecimentos prévios. As conjeturas levantadas por diversos alunos indiciaram preocupações temporais e sociais na interpretação das fontes, o que permite o reconhecimento da contextualização como ponto de partida para a consideração da evidência histórica.

Alguns alunos (3,5\% do $7 .^{\circ}$ ano e $2 \%$ do $10 .^{\circ}$ ano) revelaram inferências pessoais problematizadoras, formulando questões sobre o contexto em termos de relações temporais, ou questionando a evidência, ou colocando hipóteses à luz de possibilidades diversas. Estes alunos parecem compreender que se pode colocar questões a que as fontes não foram designadas responder e que vejam a História como inferencial, construindo o conhecimento do passado para lá do que estas fontes podem ter sido feitas para rela$\operatorname{tar}^{25}$. Alguns alunos pareceram reconhecer que as fontes disponíveis podem nunca lhes fornecer os «factos» que precisariam para chegar a conclusões firmes, admitindo que são incompletas.

Vários alunos do $10 .^{\circ}$ ano, e também do 7. ano, fizeram suposições válidas a partir dos detalhes observados, por exemplo ao nível do vestuário, usando terminologia

\footnotetext{
${ }^{23}$ LEE, 2005.

${ }^{24}$ ASHBY, 2003; SIMÃO, 2007.

${ }^{25}$ LEE, 2008.
} 
adequada e contextualizada. Como salienta $\mathrm{Chapman}^{26}$, usar hipóteses para avaliar uma interpretação pode ajudar os alunos a progredirem na interpretação e discussão de argumentos históricos. Alguns alunos de ambos os anos de escolaridade questionaram a «verdade» transmitida, levantaram questões acerca da credibilidade ou do estatuto da informação proporcionada, nomeadamente em relação ao «loudel do rei D. João I» exposto no Museu de Alberto Sampaio, indiciando entender a construção do conhecimento histórico a partir da interpretação crítica das fontes, ou seja, em termos de evidência histórica. Pareceram compreender a interação entre o passado e as representações físicas da História, não se limitando ao uso das fontes como informação ou materialização do passado, mas reconhecendo que elas devem ser interpretadas em contexto, tendo consciência da sua historicidade.

Relativamente ao tipo de pensamento que os alunos desenvolvem em situação de exploração direta de fontes patrimoniais, nomeadamente quanto ao sentido dado à relação passado-presente («consciência histórica») a partir da leitura das fontes patrimoniais, num grande número de respostas (58,9\% no $7 .^{\circ}$ ano e $52,6 \%$ no $10 .^{\circ}$ ano) os alunos avaliaram as atitudes das pessoas do passado à luz de valores do presente, ou entenderam o passado, em termos genéricos, como intemporal e, sobretudo, conceberam o passado à imagem do presente para simples conhecimento. Diversas respostas mostraram, a par do vínculo à informação disponível, ideias de compreensão do passado à luz do presente, de «presentismo» quer em termos de significância social quer no que respeita à significância pessoal, expressando ideias de progresso linear de senso comum. Os alunos pareceram referir-se a um passado que é adaptado às necessidades do presente ou assimilado a este ${ }^{27}$. Outras respostas mostraram conceções do passado como intemporal, como um conjunto de acontecimentos estáticos ou ações perenes que as fontes patrimoniais materializam e testemunham.

No entanto, várias respostas $\left(8,9 \%\right.$ no $7 .^{\circ}$ ano e $17,6 \%$ no $10 .^{\circ}$ ano) indiciaram um uso do passado em relação com um presente emocionalmente simbólico; valorizam as fontes patrimoniais no passado e presente pelo seu simbolismo ou monumentalidade, revelando um sentido de identidade local ou nacional menos ou mais acentuado. Alguns alunos centraram-se na valorização dos vestígios patrimoniais como evocação de acontecimentos emblemáticos de um passado «dourado» — assemelhando-se ao tipo de consciência «tradicional» de Rüsen ${ }^{28}$ ou de tipo «monumental» de Seixas e Clark ${ }^{29}$ que dá consistência à identidade local. Outras respostas parecem conceber uma continuidade do passado que pode ser garantida pela preservação do património, constituindo os antepassados, que se sacrificaram pelas gerações seguintes, um modelo para

\footnotetext{
${ }^{26}$ CHAPMAN, 2006.

${ }^{27}$ LEE, 2002.

${ }^{28}$ RÜSEN, 2004.

${ }^{29}$ SEIXAS \& CLARK, 2004.
} 
o presente. Este reconhecimento da obrigação moral de dar continuidade ao legado dos antepassados parece corresponder ao tipo de consciência «exemplar» de Rüsen ${ }^{30}$ ou de tipo «antiquário» de Seixas e Clark ${ }^{31}$, nomeadamente em termos da significância pessoal atribuída às fontes patrimoniais, exprimindo uma relação emocional entre identidade e património local. Em termos de significância social, uma conceção do passado como repositório de exemplos que devem guiar o presente e informar as ações futuras, reconhecendo o património local como símbolo associado a um sentido de identidade nacional, emergiu num número expressivo de respostas. Salientaram principalmente o passado cultural - a cultura forma um continuum entre o passado e o presente - pelo que um objeto ou sítio histórico deve ser preservado como elemento da cultura material e da herança cultural que compõem a identidade. No, entanto, os alunos também tenderam a valorizar fontes patrimoniais relacionadas com a identidade nacional porque consideraram o seu conteúdo historicamente significante em termos políticos, artísticos ou religiosos, parecendo considerar que os vestígios que não memorializam os esforços humanos nessas áreas não são históricos.

Foram raros os alunos que revelaram um pensamento semelhante ao tipo de consciência «crítica» de Rüsen ${ }^{32}$ e de Seixas e Clark ${ }^{33}$, desafiando um passado aceite. Apenas um grupo muito restrito (três alunos) referiu a destruição/realização de obras de modernização do local ou propôs formas de obviar algumas limitações existentes, nomeadamente pelo esclarecimento do público. Várias respostas de alunos do $10 .^{\circ}$ ano $(16,4 \%)$, mas também do $7 .^{\circ}$ ano $(11,4 \%)$, revelaram uma compreensão da relação passado-presente de forma linear relativamente ao uso e função das fontes patrimoniais e características socioeconómicas associadas ao passado ou ao presente, embora procedessem à sua contextualização, revelando uma orientação temporal emergente. Diversos alunos utilizaram um conceito de mudança como desenvolvimento - o que, segundo $\mathrm{Lee}^{34}$, revela um nível de compreensão relativamente elevado - e expressaram ideias de mudança/permanência ou de causa/consequência ligadas a uma noção de progresso linear, embora algumas respostas já indiciem a perceção de diferentes ritmos de mudança. Menos frequentes ( $1,1 \%$ no $7 . .^{\circ}$ ano e $4,6 \%$ no $10 .^{\circ}$ ano) foram as respostas em que o sentido relacional entre passado, presente e futuro revelou a utilização de noções de mudança e permanência como formas de conceptualizar as relações entre fenómenos em diferentes momentos do tempo ${ }^{35}$.

\footnotetext{
${ }^{30}$ RÜSEN, 2004.

${ }^{31}$ SEIXAS \& CLARK, 2004.

${ }^{32}$ RÜSEN, 2004.

${ }^{33}$ SEIXAS \& CLARK, 2004.

${ }^{34}$ LEE, 2002.

${ }^{35}$ LEE, 2003.
} 
Um grupo restrito de alunos revelou consciência histórica explícita no reconhecimento de diversidade na mudança relativamente a características socioeconómicas e ao uso ou função das fontes patrimoniais no passado e no presente. Considerou esse diálogo relacional com base no conhecimento histórico, aplicando, por vezes, conceitos próprios da metodologia da História. Alguns alunos reconheceram diferentes ritmos de mudança, umas mais rápidas e visíveis (nomeadamente as transformações tecnológicas) e outras mais lentas e quase impercetíveis - mudanças na mentalidade e nos comportamentos e permanência de determinadas práticas na atualidade - localizando áreas de continuidade e semelhanças entre o passado e o presente, e até a coexistência, numa determinada época, de realidades distintas.

Saliente-se, finalmente, que os perfis conceptuais que surgiram neste estudo não são fixos, os alunos oscilaram nas suas respostas ao guião-questionário (e mesmo nas entrevistas), em função do tipo de tarefa. Pretendeu-se integrar a abordagem da construção da evidência histórica no âmbito da investigação em Educação Histórica, propondo atividades educativas de exploração de fontes patrimoniais, articulando-as com os currículos de História do $3 .^{\circ}$ ciclo do ensino básico e do ensino secundário, num contexto específico e com vestígios patrimoniais de diferentes épocas.

Em novas investigações, continua a ser de todo o interesse a exploração de outras fontes patrimoniais, similares ou de outras épocas, mais antigas ou mais recentes, e com jovens de outros grupos etários e anos de escolaridade, realizando estudos transversais. Podem propor-se outras tarefas, usando as mesmas questões, mas debruçando-se sobre fontes progressivamente mais complexas, desde um fragmento a fontes com diferentes pontos de vista, no caso de fontes escritas, ou com vestígios de várias épocas num mesmo local, no caso de fontes patrimoniais.

Embora a maioria das situações de ensino tenha lugar na sala de aula, algumas, talvez até mais produtivas em termos da aprendizagem dos alunos, realizam-se no exterior, em sítios históricos, museus e, mesmo, no meio envolvente da escola. Reconhecer este potencial é desafiador para a investigação em Educação Histórica, pois implica que se desenvolvam estudos que atendam à forma como os alunos aprendem em diferentes contextos e ao tipo de abordagem mais adequada para desenvolver, por exemplo, a leitura de vestígios arqueológicos, edifícios, objetos de museus ou narrativas de história oral ou de saber-fazer tradicional, sem perder de vista a sua inserção num processo e envolvendo os alunos na construção do seu conhecimento histórico. 


\section{BIBLIOGRAFIA}

AGUILERA, Carmen; VILLALBA, Maria (1998) — „Vamos al Museo! Guías y recursos para visitar los Museos. Madrid: Narcea S.A. de Ediciones.

ASHBY, Rosalyn (2003) - O conceito de evidência histórica: exigências curriculares e concepções dos alunos. In BARCA, Isabel, org. - Educação Histórica e Museus. Actas das Segundas Jornadas Internacionais de Educação Histórica. Braga: CIEd/Universidade do Minho, p. 37-57.

ASHBY, Rosalyn; LEE, Peter (1987) - Children's concepts of empathy and understanding in history. In PORTAL, Christopher, ed. - The History Curriculum for Teachers. London: The Falmer Press, p. 62-88.

ASHBY, Rosalyn; LEE, Peter; SHEMILT, Denis (2005) - Putting principles into practice: teaching and planning. In DONOVAN, M. Suzanne; BRANSFORD, John D., eds. - How students learn: History in the classroom. Washington, D. C.: The National Academies Press, p. 79-178.

BARCA, Isabel (2000) - O Pensamento Histórico dos Jovens: Ideias dos adolescentes acerca da provisoriedade da explicação histórica. Braga: CEEP/Universidade do Minho.

(2004) - Aula Oficina: do Projecto à Avaliação. In BARCA, Isabel, org. - Para uma Educação Histórica com Qualidade: Actas das IV Jornadas Internacionais de Educação Histórica. Braga: CIEd/Universidade do Minho; Instituto de Educação e Psicologia/Universidade do Minho, p. 131-144.

BARCA, Isabel; GAGO, Marília (2000) - De pequenino se aprende a pensar: Formar opinião na aula de História e Geografia de Portugal. Lisboa: Associação de Professores de História. (Cadernos Pedagógico-Didácticos; 23).

BARTON, Keith (2001) - Ideias das crianças acerca da mudança através dos tempos: resultados de investigação nos Estados Unidos e na Irlanda do Norte. In BARCA, Isabel, org. - Perspectivas em Educação Histórica. Actas das Primeiras Jornadas Internacionais de Educação Histórica. Braga: CEEP/Universidade do Minho, p. 55-68.

CASTRO, Júlia (2006) - A Interculturalidade e o Pensamento Histórico dos Jovens. Braga: Universidade do Minho. Tese de doutoramento.

CHAPMAN, Arthur (2006) - Asses, archers and assumptions: strategies for improving thinking skills in history in years 9 to 13. «Teaching History», n. ${ }^{\circ} 123$, p. 6-13.

CHOAY, Françoise (2000) - A Alegoria do Património. Lisboa: Edições 70.

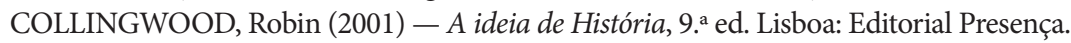

COOPER, Hilary (1992) - The teaching of History. London: David Fulton.

DICKINSON, Alaric; LEE, Peter (1984) - Making sense of History. In DICKINSON, Alaric; LEE, Peter; ROGERS, P., eds. - Learning History. London: Heinemann, p. 117-153.

EGAN, Kieran (1994) - O uso da narrativa como técnica de ensino. Lisboa: Dom Quixote.

LEE, Peter (2001) - Progressão da compreensão dos alunos em História. In BARCA, Isabel, org. - Perspectivas em Educação Histórica. Actas das Primeiras Jornadas Internacionais de Educação Histórica. Braga: CEEP/Universidade do Minho, p. 13-27.

(2002) - «Walking backwards into Tomorrow»: historical consciousness and understanding History. Disponível em <http://www.cshc.ubc.ca>. [Consulta realizada em 10/03/2011].

(2003) - «Nós fabricamos carros e eles tinham que andar a pé»: compreensão da vida no passado. In BARCA, Isabel, org. - Educação Histórica e Museus. Actas das Segundas Jornadas Internacionais de Educação Histórica. Braga: CIEd/Universidade do Minho, p. 19-36.

(2005) - Putting principles into practice: understanding History. In DONOVAN, M. Suzanne; BRANSFORD, John D., eds. - How students learn: History, Mathematics and Science in the classroom. Washington, D. C.: The National Academies Press, p. 31-78.

(2008) - Educação histórica, consciência histórica e literacia histórica. In BARCA, Isabel, org. Estudos de Consciência na Europa, América, Ásia e África. Actas das Sétimas Jornadas Internacionais de Educação Histórica. Braga: CIEd/Universidade do Minho, p. 11-32. 
LEE, Peter; ASHBY, Rosalyn (2001) - Empathy, perspective taking, and rational understanding. In DAVIS, O. L.; YEAGER, Elizabeth; FOSTER, Stuart, eds. - Historical empathy and perspective taking in the social studies. Oxford: Rowman \& Littlefield Publishers, p. 21-50.

LEE, Peter; DICKINSON, Alaric; ASHBY, Rosalyn (1996) - Progression in children's ideas about history. In HUGHES, M., ed. - Progression in learning (BERA Dialogue). Clevedon, Bristol (PA) and Adelaide: Multilingual Matters.

PAIS, José M. (1999) - Consciência histórica e identidade: os jovens portugueses num contexto europeu. Oeiras: Celta Editora.

PINTO, Helena (2003) - Guimarães, Centro Histórico: Património e Educação. Universidade do Minho. Dissertação de Mestrado em Património e Turismo. (2011) - Educação histórica e patrimonial: conceções de alunos e professores sobre o passado em espaços do presente. Braga: Universidade do Minho. Tese de doutoramento. Disponível em $<\mathrm{http} / / /$ repositorium.sdum.uminho.pt/handle/1822/19745>.

— (2016) - Educação histórica e patrimonial: conceções de alunos e professores sobre o passado em espaços do presente. Porto: CITCEM.

RÜSEN, Jörn (2004) - Historical Consciousness: narrative structure, moral function, and ontogenetic development. In SEIXAS, Peter, ed. - Theorizing Historical Consciousness. Toronto: University of Toronto Press, p. 63-85.

SEIXAS, Peter; CLARK, Penney (2004) - Murals as monuments: students' ideas about depictions of civilization in British Columbia. «American Journal of Education», vol. 110, n. ${ }^{\circ}$ 2, p. 146-171.

SHEMILT, Denis (1987) - Adolescent ideas about evidence and methodology in history. In PORTAL, Christopher, ed. - The history curriculum for teachers. London: The Falmer Press, p. 39-61.

SIMÃO, Ana Catarina Gomes (2007) - A construção da evidência histórica: concepções de alunos do $3 .^{\circ}$ ciclo do ensino básico e secundário. Braga: Universidade do Minho. Tese de doutoramento.

STRAUSS, Anselm; CORBIN, Juliet (1998) - Basics of qualitative research: techniques and procedures for developing Grounded Theory. Thousand Oaks: Sage. 


\title{
EDUCAÇÃO HISTÓRICA: PERSPETIVAS DE APRENDIZAGEM DA HISTÓRIA DOS ALUNOS DE ALGUMAS ESCOLAS SECUNDÁRIAS DE BENGUELA/ANGOLA
}

\author{
ANGELINA AGUIARES NGUNGUI*
}

\begin{abstract}
Resumo: A Educação Histórica em Angola constitui um domínio do conhecimento desconhecido, pelo que o trabalho que aqui se apresenta é resultado do programa de doutoramento desenvolvido de 2012 a 2017 na Universidade do Minho, intitulado Construir conhecimento histórico em contexto angolano: um estudo em torno de uma experiência de "aula oficina», que buscou perceber as ideias dos alunos e professores através da metodologia de natureza construtivista social. No ano 2018, o Conselho Científico do Instituto Superior de Ciências da Educação de Benguela aprovou o projeto investigativo denominado Educação Histórica: uma abordagem inovadora para ensinar e aprender História, que envolve estudantes em fase de elaboração das suas monografias de fim de curso. As aulas oficinas desenvolvidas, através da pesquisa-ação, conduziram à emersão de categorias de respostas por parte dos alunos que oscilaram entre «válida» e «memorização com texto em falta».
\end{abstract}

Palavras-chave: Educação histórica; Aula oficina.

Abstract: Historical Education in Angola is a domain of unknown knowledge, so the work presented here is the result of the PhD program developed from 2012 to 2017 at the University of Minho, entitled Building historical knowledge in an Angolan context: a study around a «workshop class» experience, that sought to understand the ideas of students and teachers through the social constructivist methodology. In 2018, the Scientific Council of the Higher Institute of Educational Sciences of Benguela approved the research project called Historical Education: An Innovative Approach to Teaching and Learning History, which involves students in the process of preparing their final monographs. The workshops developed through action research led to the emergence of categories of responses by students who ranged from «valid» to «memorization with missing text».

Keywords: Historical education; Workshop class.

\section{INTRODUÇÃO}

Este trabalho reflete o resultado do programa de doutoramento desenvolvido dos anos 2012 a 2017, na Universidade do Minho, intitulado Construir conhecimento histórico em contexto angolano: um estudo em torno de uma experiência de "aula oficina», que buscou perceber as ideias dos alunos e professores, formulando um problema de investigação que encerrou dois enfoques: «Será possível e de que formas implementar com sucesso uma aula construtivista de História (aula oficina) em contexto angolano?»e "Que tipos de ideias de História (aula oficina) manifestam os alunos no contexto angolano?». Para o efeito, este estudo alicerçou-se fundamentalmente numa metodologia

\footnotetext{
* Instituto Superior de Ciências da Educação de Benguela, Angola. aguiaresa@gmail.com.
} 
qualitativa ancorada na Grounded Theory. Desenvolveu-se ao longo de várias etapas de recolha de dados (estudo exploratório, piloto e final), para refinamento dos procedimentos metodológicos e da análise de dados. Os sujeitos participantes, ao longo do estudo, envolveram um total de 74 alunos das $100^{a}$ e $11 .^{a}$ classes, e 4 professores, em duas escolas de Benguela. Diversos instrumentos foram utilizados: o inquérito por questionário para os alunos, e inquérito por entrevistas e questionários para os professores (estagiários e docentes experientes) e guião de observação de aulas. A análise indutiva das produções dos alunos e dos dados fornecidos pelos professores teve em conta a qualidade do pensamento histórico dos alunos e as conceções dos professores à luz da epistemologia da História e do paradigma construtivista. Dos dados obtidos dos alunos criaram-se categorias de ideias substantivas e de segunda ordem em História, nomeadamente sobre a compreensão acerca da epistemologia da «História da África» e acerca da «Invasão e Partilha da África» nos estudos exploratório e piloto, e sobre a interpretação de fontes acerca da Partilha da África sobretudo no estudo final. No estudo final, gerou-se um conjunto de constructos focados na interpretação de fontes, que vão da interpretação de senso comum à interpretação (histórica) de fontes.

Neste diapasão, após a conclusão do doutoramento, o Conselho Científico do Departamento de Ciências Sociais da especialidade de História do Instituto Superior de Ciências da Educação de Benguela (ISCED-Benguela) da Universidade Katyavala Bwila, Angola, aprovou o projeto investigativo denominado Educação Histórica: uma abordagem inovadora para ensinar e aprender História, inicialmente formada por uma equipa de 5 (cinco) docentes e que atualmente integra apenas a coordenadora do projeto e os estudantes a desenvolverem os seus trabalhos de fim de curso.

Atualmente contam-se cinco trabalhos defendidos no âmbito da abordagem Educação Histórica, realizados por alunos em graduação da Licenciatura em História do ISCED-Benguela, com os seguintes títulos: Aplicabilidade de uma aula com característica construtivista nos alunos da 11. ${ }^{a}$ Classe, do curso de Ciências Económico-Jurídicas da Escola Secundária do II Ciclo do Ensino Geral BG - 1062 Benguela $^{1}$; A aula oficina como forma de elevar a qualidade do processo de ensino aprendizagem na disciplina de História: uma experiência com os alunos da 9. ${ }^{a}$ classe da Escola BG 1000 Bairro 70 Benguela²; A avaliação construtivista: sua influência no processo de ensino-aprendizagem na disciplina de História na 9. ${ }^{a}$ classe no Colégio BG 1000 Bairro 70 Benguela ${ }^{3}$; Constructos históricos dos alunos da 10. ${ }^{a}$ classe da escola secundária do II Ciclo Liceu da Ganda BG 5186, sobre a música "os meninos do Huambo"4; e por fim, Pensamento histórico revelado

\footnotetext{
${ }^{1}$ CHITAI, 2017.

${ }^{2}$ MARTINS, 2019.

${ }^{3}$ CHIMBIRA, 2019.

${ }^{4}$ ISMAEL, 2018.
} 
pelos alunos da escola do ensino secundário do I ciclo do ensino geral do Lobito, sobre a matéria do renascimento da Europa, diante da aula oficina.

Em 2018, foi ministrado um curso curto com a participação de 25 estudantes e 2 docentes no âmbito da extensão universitária à luz do projeto Educação Histórica e perseguiu os seguintes objetivos: definir os termos utilizados no domínio da Educação Histórica; estudar as matérias que permeiam a abordagem em torno da natureza do conhecimento histórico; discutir sobre a questão da metodologia da investigação em Educação Histórica e a possibilidade de elaboração de artigos, periódicos, posters, monografias, entre outras formas de comunicação científica neste domínio. Outrossim, alguns artigos e monografias se têm desenvolvido como resultado desta difusão, embora incipiente, no contexto em foco.

O objetivo central para a ministração do curso curto aos estudantes do $4 .^{\circ}$ ano de Licenciatura em História prendeu-se com o facto de estes se encontrarem em fim de formação, e o seu perfil de saída os convocar a exercerem a sua atividade profissional no ensino secundário; assim com esta formação ocorre a possibilidade de obtenção de conhecimento teórico e metodológico das investigações no âmbito da Educação Histórica, com ênfase nos conceitos de literacia histórica, fonte histórica, conceitos substantivos e epistemológicos, produção de narrativas em aulas de História, tendo como referência autores como Lee ${ }^{6}$, Barca $^{7}$ e Schmidt ${ }^{8}$, entre outros.

Outrossim, esta formação coloca-os diante de uma abordagem desconhecida, porém inovadora, pois nesta realidade mantém-se a visão rígida do ensino da História voltada para a memorização de grandes quantidades de conteúdo, da ideia de que o professor deve elaborar todo o material para o aluno, em suma, dá-se ênfase ao ensino centrado na reprodução de conteúdos em detrimento da pesquisa científica. Observa-se a desmotivação pelo ensino da História, entre outros males evidentes a olhos vivos. Enveredamos por esta trilha alicerçados na ideia de Barca durante as orientações do programa de doutoramento, de que era imperioso promover o entusiasmo entre os professores mostrando a eles como é importante buscar em suas atividades um envolvimento que pode ser feito, por exemplo, através de atividades investigativas.

Resultado das perplexidades e reflexões sobre as mudanças que se devem efetuar na realidade em reportagem, questionamos: que ideias históricas apresentam os alunos inquiridos nos estudos realizados no âmbito do referido projeto?

\footnotetext{
${ }^{5}$ PUTU, 2019.

${ }^{6}$ LEE, 2001.

${ }^{7}$ BARCA, 2006.

${ }^{8}$ SCHMIDT, 2004.
} 
Buscou-se determinar como objetivo específico: analisar que tipologias de ideias históricas manifestam os alunos quando submetidos a tarefas multiperspetivadas durante as aulas oficinas realizadas por Chitai ${ }^{9}$; Ismael ${ }^{10}$; Martins ${ }^{11}$; Chimbira ${ }^{12}$ e Putu ${ }^{13}$.

\section{A AULA OFICINA EM BENGUELA}

Os professores que desenvolveram os projetos, sob os quais os resultados são revelados neste estudo, são maioritariamente professores a lecionarem no ensino secundário com mais de cinco anos de trabalho e atuam dando aulas de História normalmente, exceto uma professora que leciona em regime de monodocência, neste caso lecionando aulas de estudo do meio que integram lições de Geografia e de História.

Como tenho referido em alguns artigos, o processo de ensino e aprendizagem na realidade angolana é predominantemente tradicional, o que sugere que os professores realizam as suas atividades não tendo o aluno como o centro da aprendizagem; e assim é com os professores, quando começam a tomar contacto com a abordagem Educação Histórica; «observa-se o franzir do sobrolho, algumas reticências no ato da planificação... os alunos conseguirão por si só construir a aprendizagem?», questionam-se os professores; sente-se a perda da falta de controle da sala de aula e dos atos aí desenvolvidos, a dificuldade de olhar para o aluno como um ser pensante com ideias próprias e que $\mathrm{o}$ professor precisa considerar, para que se efetive o processo de aprendizagem centrado no aluno... então a questão da prática de fazer a teoria se faz notória, quando se trabalha concretamente a aula oficina considerando os pressupostos teóricos e metodológicos da aula oficina de Isabel Barca ${ }^{14}$. Como advoga muito bem a autora, ensinar História, nessa perspetiva, requer alguns princípios norteadores para a aula de História, entre eles, o de levantar e trabalhar de forma multiperspetivada as ideias prévias que os alunos manifestam tacitamente, alertando também para a necessidade de prestar atenção a essas ideias prévias porque podem ser mais vagas ou mais precisas, mais alternativas à ciência ou mais consentâneas com esta ${ }^{15}$.

\section{METODOLOGIA}

Trata-se de estudos de natureza qualitativa, centrados na obtenção direta dos dados, visando a compreensão de que principais abordagens foram contempladas nos programas utilizados pelas diferentes escolas do ensino secundário, para compreender o que os participantes pensam e dizem nos contextos onde realizam as suas práticas,

\footnotetext{
${ }^{9}$ CHITAI, 2017.

${ }^{10}$ ISMAEL, 2018.

${ }^{11}$ MARTINS, 2019.

${ }^{12}$ CHIMBIRA, 2019.

${ }^{13}$ PUTU, 2019.

${ }^{14}$ BARCA, 2004.

${ }^{15}$ BARCA, 2004.
} 
com a intenção de captar e perceber a realidade e as questões contextuais. Um investigador estranho ao contexto dificilmente obteria tais informações ${ }^{16}$. Trata-se de estudos de natureza descritiva e essencialmente qualitativa, que se preocupam em entender em profundidade o fenómeno em análise, ou seja, compreender o pensamento histórico dos intervenientes na experiência de aula oficina.

Foi privilegiada a interpretação dos dados através de uma análise indutiva inspirada no método da Grounded Theor $y^{17}$ no sentido de uma concetualização que atende ao contexto em estudo.

\section{ANÁLISE DE DADOS}

Para a análise dos dados, destaco as principais categorias de respostas emergidas nos estudos-pilotos realizados pelos autores Chitai $^{18}$ e Ismael ${ }^{19}$ por uma questão de economia de espaço. Os trabalhos de monografia dos quais nos servimos foram realizados através de aulas oficinas em diferentes etapas: Chitai realizou 2 estudos exploratórios e 2 estudos-pilotos; Ismael realizou 1 estudo exploratório e 1 estudo-piloto, tendo em atenção o grau de complexidade da matéria lecionada e o tempo disponibilizado pelas escolas onde decorreram as experiências.

O estudo-piloto realizado por Chitai subordinou-se ao programa da $11 .^{\text {a }}$ classe na Unidade 5: A revolta Anticolonial e a luta de Libertação Nacional (1962-1975), com a Subunidade 5.2.3: O 15 de Março de 1961 e a revolta generalizada no noroeste de Angola. Diante de uma atividade de carácter grupal, em que se convocava os estudantes a observarem e interpretarem as fontes 1 e 2 (em anexo), emergiram nas suas respostas categorias: «Válida» e "Válida sofisticada». Nota-se a diluição da categoria «Inválida», categoria emergida em exercícios anteriores. Assim, as respostas dos alunos foram agrupadas nas seguintes categorias:

Válida: um grupo de alunos revelou as características da fonte, mas de forma superficial, contudo as questões de clareza e objetividade foram notórias.

Válida sofisticada: nota-se, na interpretação do grupo, o estabelecimento de relações entre as fontes e as suas ideias prévias, fazendo relações bem fundamentadas diante da fonte proposta. Este grupo de alunos descreveu características subentendidas que não foram reveladas durante as aulas.

A seguir, apresenta-se a tabela 1, que evidencia os grupos participantes na atividade e as categorias emergidas durante a experiência letiva.

\footnotetext{
${ }^{16}$ BURGESS, 1997.

${ }^{17}$ STRAUSS \& CORBIN, 1998.

${ }^{18}$ CHITAI, 2017.

${ }^{19}$ ISMAEL, 2018.
} 
Tabela 1. Respostas ocorridas durante a atividade grupal

\begin{tabular}{c|c}
\hline Categorias & N.ºs dopos \\
\hline Válida & 4 \\
\hline Válida sofisticada & 1 \\
\hline Total & 5 \\
\hline
\end{tabular}

Fonte: Elaboração própria

Já no estudo-piloto realizado por Ismael, servimo-nos da ministração de uma aula sobre a música «Os meninos do Huambo» do autor Ruy Mingas. Solicitou-se aos alunos a leitura e interpretação da referida música. Com esta orientação, as respostas dos alunos agruparam-se em duas categorias:

Memorização com texto em falta: Os alunos copiaram o conteúdo da música para realização da tarefa orientada, mas copiaram apenas as palavras que lhes interessaram.

Memorização com surgimento de nova ideia: Os alunos copiaram o conteúdo da música, porém acrescentaram algumas ideias que não faziam parte da música.

A tabela 2 revela as categorias de respostas em que se enquadraram os alunos e o número de respostas ocorridas durante a realização do exercício.

Tabela 2. Categorias emergidas no momento de metacognição do estudo-piloto

\begin{tabular}{|c|c|}
\hline Categorias & N. dos Grupos \\
\hline Memorização com nova ideia & 1 Grupo \\
\hline $\begin{array}{c}\text { Memorização com texto em } \\
\text { falta }\end{array}$ & 2 Grupos \\
\hline
\end{tabular}

Fonte: Elaboração própria

Como se constata na tabela 1 , as respostas dos alunos situaram-se ao nível da categoria «Válida», 4 grupos evidenciaram-se a este nível no processo de interpretação de fontes, apenas 1 grupo se situou ao nível da categoria «Válida com sofisticação». Quanto aos resultados alcançados relacionados com a tabela 2, constata-se apenas 1 grupo a incidir as suas respostas na categoria «Memorização com surgimento de nova ideia», enquanto 2 grupos revelam a categoria «Memorização com texto em falta». Houve maior dificuldade em os alunos alcançarem a excelência, o que nos conduz à ideia de que a metodologia não tenha sido apreendida convenientemente, a tipologia de atividades submetidas aos alunos ser mais complexa em detrimento das competências que 
detêm para resolver tarefas desta natureza, em que se exige a utilização do pensamento crítico, o reelaborar das suas ideias prévias, para a sua aplicação em situações novas.

Apelar aos professores a utilização do trabalho em grupo, por tornar as aulas mais prazerosas/atrativas e dinâmicas, pois contribuem para a interação social, a socialização, confiança, autoestima e troca de informações, o que é útil também para a inserção social do aluno hoje adolescente/jovem, amanhã um ser ativo na sociedade em que estiver inserido.

\section{CONSIDERAÇÕES FINAIS}

Após as análises efetuadas aos dados resultantes das aulas oficinas, pode-se depreender que há um longo trajeto a percorrer relacionado com a área da Educação Histórica, conquanto os atores-chave deste processo nos ensaios realizados perceberam ser possível a aplicação de uma metodologia, trabalhosa mas frutuosa, no sentido de que desvela as dificuldades dos alunos em desenvolver um pensamento histórico e concomitantemente as dos professores. Tem-se a consciência de que as dificuldades denotadas podem ser consentâneas com o facto de os alunos estarem acostumados a aulas de outra natureza; com o tipo de música proposta por exemplo; com as fontes utilizadas; ou com o método e a forma de ensinar. A verdade é que esta tipologia de aulas desvela dificuldades que podem constituir um fio condutor para que o professor reflita sobre como ensina determinados conteúdos, e a possibilidade de adaptar as práticas de ensino às dificuldades observadas nos alunos e a sua melhoria continuamente.

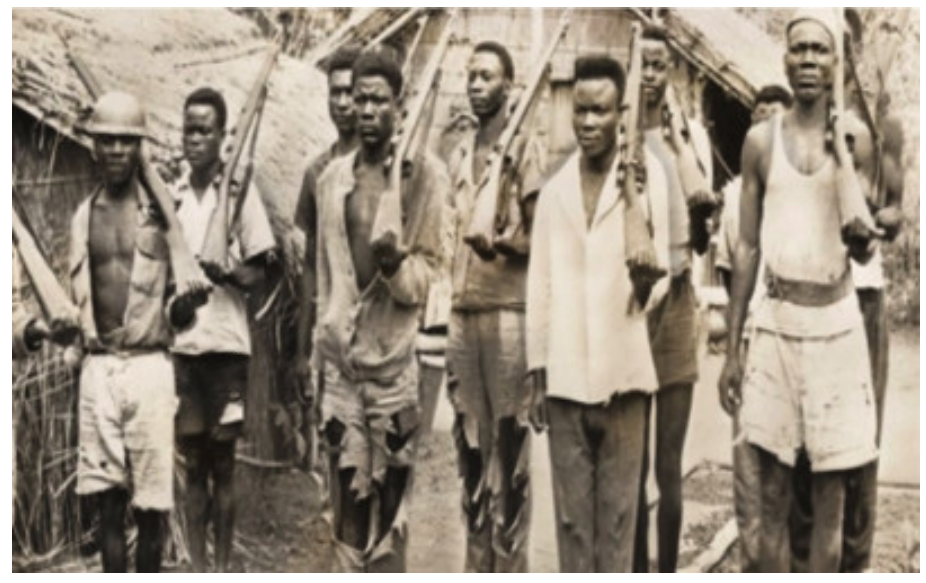

Fig. 1. Homens armados em parada. Fonte: $<$ http://noticias. sapo.ao/info/artigo/1465050. html >. [Consulta realizada em 21/12/2016] 


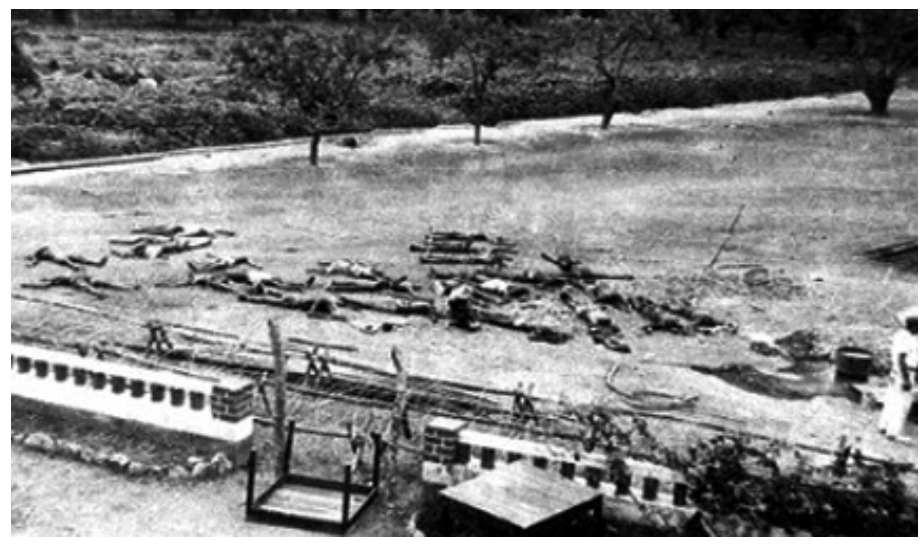

Fig. 2. Cádaveres em campo de batalha. Fonte: <http://noticias. sapo.ao/info/artigo/1465050. html >. [Consulta realizada em 21/12/2016]

\section{BIBLIOGRAFIA}

BARCA, Isabel (2004) - Aula Oficina: do Projecto à Avaliação. In BARCA, Isabel, org. - Para uma Educação Histórica com Qualidade: Actas das IV Jornadas Internacionais de Educação Histórica. Braga: CIEd/Universidade do Minho; Instituto de Educação e Psicologia/Universidade do Minho, p. 131-144. (2006) - Literacia e consciência histórica. «Educar em Revista». Dossiê Especial: Educação Histórica, vol. 22. Curitiba: UFPR, p. 93-112.

BURGESS, Robert (1997) - A Pesquisa no Terreno: uma introdução. 2. ${ }^{\text {a }}$ edição. Oeiras: Celta Editora.

CHIMBIRA, Fonseca (2019) - A avaliação construtivista: sua influência no processo de ensino-aprendizagem na disciplina de História na 9. ${ }^{a}$ classe no Colégio BG 1000 Bairro 70 Benguela. Benguela: Universidade Katyavala Bwila. Monografia de licenciatura.

CHITAI, Benjamim (2017) - Aplicabilidade de uma aula com característica construtivista nos alunos da 11. ${ }^{a}$ Classe, do curso de Ciências Económico-Jurídicas da Escola Secundária do II Ciclo do Ensino Geral $B G$ - 1062. Benguela: Universidade Katyavala Bwila. Monografia de licenciatura.

ISMAEL, Gabriel (2018) - Constructos históricos dos alunos da $10 .^{a}$ classe da escola secundária do II Ciclo Liceu da Ganda BG - 5186, sobre a música «os meninos do Huambo». Benguela: Universidade Katyavala Bwila. Monografia de licenciatura.

LEE, Peter (2001) — Progressão da compreensão dos alunos em História. In BARCA, Isabel, org. - Perspectivas em Educação Histórica: Actas das Primeiras Jornadas Internacionais de Educação Histórica. Braga: CEEP/Universidade do Minho, p. 13-27.

(2016) - Literacia histórica e história transformativa. «Educar em Revista», vol. 32, n. ${ }^{\circ}$ 60. Curitiba: UFPR, p. 107-146.

MARTINS, Edna Laurieta (2019) - A Aula Oficina como forma de elevar a qualidade do processo de ensino aprendizagem na disciplina de História: uma experiência com os alunos da 9. ' classe da escola BG 1000 Bairro 70. Benguela: Universidade Katyavala Bwila. Monografia de licenciatura.

NGUNGUI, Angelina (2017) - Construir conhecimento histórico em contexto angolano: um estudo em torno de uma experiência de «aula oficina». Braga: Universidade do Minho. Tese de doutoramento.

PUTU, Moisés (2019) - Pensamento histórico revelado pelos alunos da escola do ensino secundário do I ciclo do ensino geral do Lobito, sobre a matéria do renascimento da Europa, diante da aula oficina. Benguela: Universidade Katyavala Bwila. Monografia de licenciatura. 
SCHMIDT, Maria Auxiliadora (2004) — História com Pedagogia: a contribuição da obra de Jonathas Serrano na construção do código disciplinar da História no Brasil. «Revista Brasileira de História», vol. 24, n. 48. São Paulo: UFPR, p. 189-211.

STRAUSS, Anselm; CORBIN, Juliet (1998) - Basics of qualitative research: Techniques and procedures for developing grounded theory. 2nd ed. Sage Publications, Inc.

(2008) - Pesquisa qualitativa. 2. edição. Porto Alegre: Artmed. 


\title{
EDUCAÇÃO HISTÓRICA E FORMAÇÃO CONTINNUA (OU DOS PROFESSORES E DAS PRÁTICAS)
}

\author{
MARIANA LAGARTO*
}

Resumo: Neste artigo reflete-se sobre a relação intrínseca entre Educação Histórica e a melhoria das práticas dos professores em torno do desenvolvimento das competências específicas em História propostas no currículo da disciplina desde 2000. Para que essa melhoria se produzisse a formação contínua constituiu-se como veículo, tendo a Associação de Professores de História (APH) promovido congressos, jornadas e ações de formação. Foi assim que esta investigadora, ainda como professora, conheceu Isabel Barca, cujas ideias, nomeadamente a «aula-oficina», foram a inspiração que a levaram a aprofundar experiências de ensino em aula e, mais tarde, a abraçar um projeto de doutoramento sob a sua seminal orientação.

As conclusões desse estudo destacaram um modelo de Desenvolvimento de Competências em História, organizado a partir das intervenções dos alunos em três níveis concetuais (Reprodução, Interpretação e Compreensão) e evidenciaram que as ideias mais sofisticadas decorriam da qualidade dos desafios cognitivos para a promoção de aprendizagens significativas. Da análise de dados emergiram 7 Perfis de Momentos de Docência, influenciados quer pela experiência, quer pela formação dos docentes, sendo o Perfil de maior qualidade, e com melhores resultados de aprendizagem, exibido por um único docente que salientou a importância do conhecimento epistemológico em Educação Histórica obtido por via da formação contínua. Foram estas conclusões que me inspiraram, e inspiram, a construir ofertas formativas orientadas para a mudança de práticas de ensino e de aprendizagem ancoradas na reflexão epistemológica.

Palavras-chave: Educação histórica; Competências em História; Formação contínua; Práticas de ensino e de aprendizagem.

Abstract: This paper is about the intrinsic relationship between Historical Education and the improvement of teachers' practices in developing student's specific competences in History proposed in the curriculum since 2000. Continuous teacher training was essential to produce that change and the APH (History Teachers Association in Portugal) had promoted conferences, scientific journeys and continuous history teacher training courses. That was how this researcher, as a teacher, met Isabel Barca, whose ideas were a major inspiration to lead teaching experiences on class and later to embrace a doctoral project under her seminal orientation.

The results of this study pointed out a model of the Development of Competencies in History grounded on students' interventions that revealed three levels of ideas (Reproduction, Interpretation and Understanding) and evidenced that the most sophisticated ideas are interlinked with the quality of cognitive challenges to promote meaningful learning. Seven Profiles of Teaching and Learning Moments emerged from data, influenced by teachers' experience and training, and the Profile with higher quality and better learning results was performed by a single teacher who stressed the importance of the epistemological knowledge in History Education obtained through continuous teacher training. These conclusions inspired and inspire me to develop continuous history teacher training courses oriented towards the change of teaching and learning practices rooted on epistemological reflexivity.

Keywords: History education; History competencies; Continuous teacher training; History teaching and learning.

\footnotetext{
* CITCEM/FLUP. E-mail: mjslagarto@gmail.com.
} 


\section{DA BUSCA DE MELHORES PRÁTICAS AO ENCONTRO COM A INVESTIGAÇÃO (ATRAVÉS DA FORMAÇÃO)}

Em jeito de introdução, deixarei o meu testemunho de professora, que foi lançada no ensino sem estágio profissional ${ }^{1}$ e, que por isso, sempre procurei colmatar as minhas falhas pedagógicas e didáticas, tanto através de conversas com os docentes mais experientes como aproveitando as oportunidades de formação oferecidas pelas escolas. Entretanto ia fazendo algumas leituras, numa postura autodidata, que só contextualizei devidamente no campo das teorias educativas quando me profissionalizei - o que só aconteceu em 1990.

A procura de formação voltou a tornar-se premente com a reforma educativa até porque à época estava numa escola-piloto. No entanto, a forma como o Despacho n. ${ }^{\circ}$ 162/ME/91 (introdutor da avaliação formativa de tipo construtivista) foi sendo aplicado nas escolas por onde passava e as resistências que suscitava entre os professores levaram-me de novo ao meio académico para aprofundar os meus conhecimentos sobre construtivismo e avaliação: foi assim que realizei um DUECE, na área de Avaliação em Educação/Desenvolvimento Curricular, na Faculdade de Psicologia e Ciências da Educação da Universidade de Lisboa.

O encontro com o construtivismo facilitou-me a leitura, em 2001, do Currículo Nacional do Ensino Básico ${ }^{2}$ e do Programa de História A do ensino secundário, que apresentavam as competências de forma diversa, mas foi no Currículo do Ensino Básico que encontrei a Educação Histórica através das noções de ideias tácitas, de «conceitos substantivos» e de «conceitos de segunda ordem ou metodológicos», entendidos como fundamentais para desenvolver o pensamento histórico dos alunos e a compreensão da natureza do saber histórico. Estas perspetivas de cognição histórica norteavam os três núcleos estruturantes das Competências Essenciais ou específicas em História: «Tratamento de Informação/Utilização de Fontes», «Compreensão Histórica» (no âmbito de temporalidade, espacialidade e contextualização) e "Comunicação em História». Abracei, então, a noção de que não se ensina História sem desenvolver competências e centrei-me mais em práticas de interpretação de fontes para ajudar os alunos a procurar a explicação do real.

Cedo me apercebi de que o trabalho de desenvolver práticas de avaliação construtivista e competências numa lógica emancipadora do raciocínio do aluno provocava uma grande resistência entre a maior parte dos professores, que persistiam nas velhas práticas, continuando a manter o uso de uma avaliação sumativa tradicionalmente balizada por dois testes e a afirmar não ter tempo para praticar uma avaliação formativa de tipo construtivista ou para «dar» competências face a um programa extenso, cujos

\footnotetext{
${ }^{1}$ Em 1982, a licenciatura em História na Faculdade de Letras da Universidade de Lisboa não incluía estágio.

${ }^{2}$ PORTUGAL. Direcção-Geral do Ensino Básico, 2001.
} 
conteúdos se deviam transmitir ${ }^{3}$. Não obstante, havia quem desenvolvesse algumas iniciativas de uma «história ativa» que apostava mais na transformação dos alunos em figurantes de feiras ou mercados do que na investigação inerente a esses papéis. Assim, tornou-se notória a distância da maior parte dos professores face à intencionalidade teórica das reformas, facto agravado, segundo Fernandes ${ }^{4}$, pela escassez da oferta de formação profissional. No entanto, os professores de História podiam encontrar formação na Associação de Professores de História (APH) através de publicações (como o Ensino da História) ou em formação presencial, nomeadamente os congressos. Foi aí que contactei com o meio académico da Educação Histórica em Portugal, nomeadamente com Isabel Barca e outros elementos da sua equipa: Olga Magalhães, Júlia Castro, Marília Gago, Ana Catarina Simão, Isabel Afonso, Helena Pinto e Helena Veríssimo. $\mathrm{O}$ que me agradava neste meio académico era a relação entre epistemologia e práticas de ensino.

O reencontro com Helena Veríssimo, antiga colega da escola a cujo quadro pertenço na Grande Lisboa, criou a oportunidade para aí se realizar, em 2004, em nome da $\mathrm{APH}$, o Encontro Regional «O ensino da História no contexto das reformas educativas», o que me aproximou ainda mais da Educação Histórica, nomeadamente da aula-oficina de Barca ${ }^{5}$. Tal aproximação foi reforçada pelo convite de Helena Veríssimo (estendido também a Miguel Barros) para a elaboração de um manual de História $\mathrm{A}^{6}$ de tipo construtivista.

As mudanças que esperava produzirem-se na minha escola com o Encontro Regional não só não foram assinaláveis, como os meus colegas se sentiram legitimados na defesa do ensino de conteúdos e de desvalorização das competências com a quebra dos resultados no novo modelo de exames nacionais de História A, em 2005, atitude que se revelou como tendência maioritária entre os professores, bem notória no congresso da APH, em Coimbra, em 2007.

Essa polémica suscitou-me a vontade de aprofundar as relações entre as práticas da avaliação formativa construtivista e uma melhor preparação dos alunos para o exame nacional e levou-me de volta à Faculdade de Psicologia e Ciências da Educação da Universidade de Lisboa para realizar um mestrado em avaliação das aprendizagens. Sob a orientação de Domingos Fernandes, aprofundei os meus conhecimentos em avaliação e fui motivada a estreitar laços com a Educação Histórica - foi assim que cheguei às Jornadas de Educação Histórica, no Instituto de Educação e Psicologia da Universidade

\footnotetext{
${ }^{3}$ FERNANDES, 2005; ROLDÃO, 2003.

${ }^{4}$ FERNANDES, 2005.

${ }^{5}$ BARCA, 2004.

${ }^{6}$ História em Construção 10. ${ }^{\circ}$ e 11. ${ }^{\circ}$ anos, editados em 2007 e 2008, e Nova Construção da História 12. ${ }^{\circ}$ ano, editado em 2009, pela ASA.
} 
do Minho, e à leitura integral da tese de Isabel Barca ${ }^{7}$. Entre os resultados do mestrado ${ }^{8}$ salientam-se os relacionados com a Educação Histórica, nomeadamente a evidência de que a dinâmica da aula-oficina (e a discussão dos critérios de avaliação) propiciava aos alunos maior concentração e autonomia, de que a metacognição contribuía para a responsabilização pela aprendizagem e que o uso de tarefas de aprendizagem ativa integradoras de competências, conteúdos e conceitos fomentava a construção de aprendizagens com significado?.

\section{INVESTIGANDO TEORIA E PRÁTICAS DE ENSINO, DE APRENDIZAGEM E DE AVALIAÇÃO}

A ideia de conhecer melhor as práticas de ensino, de aprendizagem e de avaliação no terreno e a relação entre a forma como os professores desenvolviam, ou não, competências no $3 .^{\circ}$ ciclo do ensino básico ${ }^{10} \mathrm{e}$ contribuíam para o pensamento histórico dos jovens foi aflorando durante o mestrado e ganhou contornos mais definidos aquando da minha participação, em Lisboa, na discussão das Metas de Aprendizagem, devido às várias dúvidas que emergiram sobre as práticas docentes. Foi esta ideia que deu origem ao projeto de doutoramento em Educação Histórica, que desenvolvi entre 2011 e 2016, sob a orientação de Isabel Barca, e que motivou a minha aproximação ao meio académico internacional através das HEIRNET (Nova Iorque em 2010 e Braga em 2011) e das Jornadas (Braga em 2011 e Curitiba em 2012 ${ }^{11}$ ).

O diagnóstico do estado do ensino da História foi feito através da observação das práticas letivas de seis docentes, com mais de 15 anos de experiência e escolhidos segundo os critérios de conveniência e variação máxima, respetivamente, o tempo e facilidade de acesso ao campo de estudo e a máxima heterogeneidade nos casos estudados. Estes docentes, que permitiram o acesso às intervenções de um total de 174 alunos, foram ainda entrevistados para se compreender como interpretavam o Currículo de 2001 e o articulavam com o desenvolvimento das competências e a sua avaliação. Daí o título: Desenvolver e avaliar competências em História: um estudo com professores do $3 .^{\circ}$ ciclo do ensino básico ${ }^{12}$ e as três questões de investigação: a) Que aspetos mais influenciam os docentes na preparação do Processo de Ensino e de Aprendizagem?; b) Que práticas de ensino, de aprendizagem e de avaliação se salientam em aula e qual o seu contributo para o Desenvolvimento de Competências em História?; e c) Qual a relação entre as

\footnotetext{
${ }^{7}$ BARCA, 2000.

${ }^{8}$ Dissertação na área de especialização em Avaliação em Educação: Avaliação Formativa e exames nacionais: análise de práticas de ensino e avaliação de uma professora da disciplina de História.

${ }^{9}$ LAGARTO, 2009.

${ }^{10}$ Este é, em Portugal, o último ciclo em que todos os alunos têm História no Currículo.

${ }^{11}$ Ano em que passaram a ser designadas como Jornadas Internacionais de Educação Histórica.

${ }^{12}$ LAGARTO, 2017.
} 
práticas de ensino e de aprendizagem e as conceções de alunos acerca da mudança e/ou continuidade em História?

A investigação desenvolveu-se em estudo exploratório, estudo-piloto e estudo final (os dois últimos englobados no estudo principal).

A metodologia utilizada foi inspirada na Grounded Theory por permitir a articulação das fases de recolha de dados com as da sua análise, o que facilita o ajuste dos instrumentos e procedimentos de recolha nas fases seguintes do estudo, bem como o refinamento constante das categorias ${ }^{13}$.

Os instrumentos de recolha de dados (questionários, guião de entrevista e linhas de registo de observação de aulas) criados para o estudo exploratório foram refinados para o estudo principal, tal como os procedimentos de recolha de dados. Passou-se da observação de aulas em que os docentes atuavam como habitualmente, antecedida de entrevista, para a realização de entrevistas após a observação das aulas e a sugestão de introdução de tarefas (acerca de mudança e/ou continuidade), recolhendo-se as respostas escritas dos alunos.

A Grounded Theory sublinha ainda a importância de enquadrar a ação humana no seu contexto e processo, porque ela não só não acontece no vácuo, como é norteada por intenções e práticas. Por isso, analisaram-se as opções dos docentes ao delinear as aulas (o Contexto) e a forma como estas se desenrolaram (o Processo, neste caso, de ensino e de aprendizagem) para melhor se compreender a Interação em torno da avaliação e do desenvolvimento das competências em História. Assim, as categorias que surgiram foram sendo organizadas em torno dos enfoques Contexto e Processo e foram exibindo Perfis de momentos de docência (e não um Perfil único por docente), que se iam entretecendo com as categorias da análise de dados das intervenções dos alunos resultantes da sua Interação com os professores, o que fez delinear um modelo de Desenvolvimento de Competências em História (adiante DCH). Na definição de categorias, foi frutuosa a comparação teórica dos dados através do constante retorno à literatura científica de referências na Educação Histórica como Ashby, Barca, Chapman, Cooper, Gago, Lee, Magalhães, Rüsen, Shemilt, Seixas, entre outros.

\subsection{Perfis de momentos de docência e Desenvolvimento de Competências em História (DCH)}

Entre os resultados mais salientes desta investigação, destacam-se a emergência de um modelo de DCH (explicado adiante) e de um conjunto de Perfis de momentos de docência (adiante Perfis) construídos a partir do cruzamento dos modelos de Contexto e de Processo e da relação entre as estratégias dos professores com a qualidade das intervenções dos alunos. Estes Perfis (num total de sete) resultaram da constatação de que os

${ }^{13}$ CORBIN \& STRAUSS, 2008. 
professores tendem a usar dois ou três tipos de práticas letivas numa mesma aula. Por um lado, foi notório que os docentes que usavam o Perfil 1 (discurso docente assente na reprodução de informação) tendiam a usar os Perfis 2 (diálogo assente em questões de rotina enquadradoras do discurso docente) e 3 (diálogo aliado a tarefas de resposta única) e, mais raramente, usavam o Perfil 4 (tarefas com várias respostas desde que devidamente justificadas). Por outro lado, os docentes que usavam maioritariamente o Perfil 4 raramente usavam o 3, e tendiam a ir até ao Perfil 6 (tarefas mais sofisticadas, mas sem discussão de resultados). O Perfil 5 correspondia às tarefas com menor grau de sofisticação e o 7 às mais sofisticadas, mas com discussão de resultados. Em todos estes Perfis se usaram fontes históricas, mas de formas quase divergentes. Nos Perfis 1 e 2 eram meras enquadradoras do discurso docente, nos restantes Perfis foram a base de tarefas, cuja complexidade oscilava em função do tipo de questões colocadas e do seu potencial para fomentar a inferência, dado que as fontes só «falam» se forem bem interrogadas ${ }^{14}$.

A análise indutiva revelou ainda que conceções de História e práticas de avaliação mais marcavam os diferentes momentos de docência. Os Perfis 1 a 3 centravam-se no ensino de conceitos substantivos e de factos pouco complexos, apesar de no Perfil 3 ocorrerem algumas situações relativas à aprendizagem da mudança em História. Em termos de práticas de avaliação, os Perfis 1 e 2 eram mais «bloomianos», manifestando o 3 traços de uma avaliação formativa construtivista, mas que se diluíam na exigência de uma resposta única, aspeto comum aos Perfis 1 e 2. Tal revelava uma conceção de História como passado fixo, assente num único quadro explicativo, estimuladora da regurgitação e reprodução de estereótipos ${ }^{15}$.

Os Perfis 4 e 5 assentavam numa conceção de História entendida como processo e possibilitadora de uma compreensão perspetivada da História ${ }^{16}$. As práticas de avaliação dos Perfis 4 e 5 aproximavam-se mais do construtivismo ainda que a metacognição fosse pouco trabalhada e não se explorassem ideias prévias. O Perfil 4 , que pode ser entendido como charneira, correspondeu aos momentos de análise e interpretação de fontes históricas, em grande grupo, em que se concedia tempo aos alunos para argumentar e discutir com os colegas as suas conclusões, passando a correção pelo esclarecimento das ideias menos adequadas em História e pela elaboração de sínteses em que se integravam os contributos válidos. O Perfil 5 (observado num docente do estudo-piloto) norteou-se pelo desafio, a uma turma de alunos muito desmotivados, de perceber a importância das fontes em História. Estes deviam, em grupo/pares, tratar a informação do manual e levantar questões às fontes e responder-lhes, numa aceção próxima do que Ashby, Lee e Shemilt já advogavam nos anos 80 .

\footnotetext{
${ }^{14}$ COOPER \& CHAPMAN, 2009.

${ }^{15}$ ASHBY \& LEE, 1987; ASHBY et al., 2005; SEIXAS \& PECK, 2004.

${ }^{16}$ LEE et al., 1993; SHEMILT, 1980; BARCA, 2000.
} 
Os Perfis 6 e 7 salientaram-se pela maior incidência em tarefas de compreensão do passado como um processo de construção, mas diferenciavam-se entre si pela enunciação das condições das tarefas e pela forma de correção: no Perfil 6 podia não haver discussão dos resultados, enquanto no Perfil 7 tal era fundamental. Outra diferença entre estes Perfis decorria do uso do feedback: nos momentos do Perfil 6 este era emitido apenas pelo docente e observando-se no Perfil 7 grande interação entre pares e uma atitude do docente que protagonizou este Perfil pautada pelo «andaimar» do pensamento histórico dos alunos numa tentativa de potenciar a formação da sua orientação temporal: «Gosto muito mais [...] de lhes andaimar (sinal de aspas) o pensamento no sentido de eles chegarem à sua resposta.» Estes entendimentos repercutiram-se no empenho dos alunos na consecução das tarefas, sendo que os do Perfil 7 revelaram maior cuidado na fundamentação das respostas, recordando uns aos outros: «É preciso explicar, o professor vai pedir para explicar.» Estes alunos sentiam também maior à-vontade na exposição das suas ideias, porque esperavam ser esclarecidos caso estas não fossem adequadas, tal como afirmou o docente: «Eu penso que consigo fazer com que eles sintam que as intervenções deles são valorizadas e que não me recuso a responder às questões deles.» Os Perfis 6 e 7 foram os que revelaram maior aproximação às práticas de avaliação formativa orientadas para a aprendizagem ${ }^{17}$ e foram os que mais contribuíram para o desenvolvimento de competências em História dos alunos e para a sua orientação temporal ${ }^{18}$. Por isso, foi nestes Perfis que se encontraram os níveis mais sofisticados de intervenções dos alunos presentes no modelo de DCH.

O modelo de DCH foi organizado em torno de três níveis concetuais, que se detetaram logo no estudo exploratório: a) o nível A, «Reprodução», abrangia categorias mais básicas de tratamento de informação, desde a simples regurgitação e manifestação de senso comum à seleção de informação sem justificação (próxima da "tesoura e cola» de Lee, Ashby e Dickinson ${ }^{19}$ ); b) o nível B, «Interpretação», englobava categorias de análise das fontes históricas desde a procura de sentido das suas mensagens (assente em estereótipos ou noções de presentismo) até situações de inferência fragmentada ou, menos comum, de inferência fundamentada em conhecimentos prévios ${ }^{20}$; e c) nível C, «Compreensão» ${ }^{21}$, com as categorias de contextualização das fontes no seu conjunto e não como fragmentos e de questionamento para enquadrar o contexto ${ }^{22}$.

\footnotetext{
${ }^{17}$ HARLEN, 2006.

${ }^{18}$ RÜSEN, 2001.

${ }^{19}$ LEE et al., 1993.

${ }^{20}$ SHEMILT, 1980; ASHBY \& LEE, 1987, GAGO, 2007.

${ }^{21}$ A designação deste nível como a do nível de «Interpretação» foram inspiradas na formulação das competências históricas do Currículo Nacional do Ensino Básico de 2001

${ }^{22}$ LEE, 2005.
} 
As categorias do $\mathrm{DCH}$ foram entendidas como níveis de constructos e não como níveis de avaliação sumativa ${ }^{23}$, sendo mais proveitosa para a avaliação das competências em História a adoção de níveis de progressão conceptual «andaimados» pela ação docente, tal como defendem Lee e Shemilt ${ }^{24}$.

$\mathrm{O}$ facto de se terem observado, no estudo exploratório, poucas situações que permitissem aceder ao raciocínio dos jovens acerca da mudança e/ou continuidade em História levou a que se criassem tarefas escritas para o estudo principal. A análise dos dados do estudo-piloto implicou uma «extensão» do modelo de DCH com seis categorias que implicavam a perceção e/ou a compreensão dos sentidos de mudança e/ou de continuidade ou a sua ausência. Estas categorias da "extensão» do modelo foram entretecidas durante a análise dos dados do estudo final com as do modelo principal de DCH por terem emergido em aula categorias conceptuais sobre mudança e continuidade, não observadas nas fases anteriores. Tal reformulação conduziu a um modelo único de DCH em que se mantiveram os três níveis concetuais e se integraram estas novas categorias: a de «mudança e/ou continuidade percecionada», integrada no nível da «Interpretação», por abarcar as ideias de evolução em História como progresso linear ${ }^{25}$, e a de «mudança e/ou continuidade compreendida», integrada no nível da «Compreensão», por incluir a reflexão sobre os sentidos da evolução em História ${ }^{26}$ e a expressão de ideias de mudança próximas de um humanismo intercultural, ainda que num registo de relativismo ingénuo $^{27}$. Apesar de a maior parte das intervenções dos alunos do estudo final se situar nos níveis da «Interpretação» e da "Compreensão», não deixaram de se registar algumas, muito poucas, no nível da «Reprodução", que consolidaram as categorias da reprodução simples de informação das aulas anteriores, do manual, de sites ou a manifestação de ideias de senso comum. Este tipo de intervenções pode ser indicativo de uma certa resistência de alguns alunos face às tarefas propostas nos Perfis 6 e 7 (os maioritariamente observados no estudo final) e poderá ser usado como etapa preparatória de uma estratégia de construção do pensamento histórico.

Na definição de categorias e na revisão de literatura, não posso deixar de destacar a importância das discussões científicas com Isabel Barca, porque, sendo uma «fonte viva» da Educação Histórica, iluminou muitas das minhas dúvidas e enriqueceu o meu conhecimento.

\footnotetext{
${ }^{23}$ ASHBY \& LEE, 1987; BARCA, 2000; SHEMILT, 1980.

${ }^{24}$ LEE \& SHEMILT, 2003.

${ }^{25}$ BARCA, 2015; SEIXAS, 2015.

${ }^{26}$ LEE, 2005.

${ }^{27}$ RÜSEN, 2015.
} 


\subsection{E a Educação Histórica no discurso e nas práticas dos docentes?}

A Educação Histórica observou-se na mudança da dinâmica da aula em que o docente do estudo-piloto que tendia a trabalhar com o Perfil 4 aplicou a tarefa proposta pela investigadora. Para tal contribuiu a explicação dos procedimentos a ter em atenção aquando da sugestão da tarefa de comparação de fontes sobre a democracia ateniense e a atual. A dinâmica adotada potenciou os resultados dos seus alunos face ao que tinha acontecido na aula realizada no registo habitual do docente, registando-se muito mais intervenções orais e escritas nas categorias do nível da "Compreensão», inclusive dos alunos mais fracos. Não obstante, o docente alegou a dificuldade de adotar este tipo de prática devido à escassez de tempo face a um currículo extenso e à (sobre)dimensão das turmas: «não tenho tempo, senão nem a meio do programa fico. [...] Trabalha-se para o tal aluno médio que não existe». Esta argumentação foi também comum entre os docentes que desempenharam os Perfis 1 a 3 , sendo que ainda alegavam que a desmotivação da maior parte dos alunos não valia a aposta noutro tipo de aulas. Curiosamente o mesmo argumento da desmotivação levou os docentes dos Perfis 5 a 7 a criar desafios cognitivos que suscitassem a procura do sentido da História, apostando na capacidade desses alunos para produzirem raciocínios mais sofisticados.

A Educação Histórica observou-se, ainda, nas aulas do docente que protagonizou o Perfil 7 que tinha feito formação contínua na APH, o que lhe aportou o conhecimento epistemológico necessário para compreender as propostas do Currículo e para construir aulas-oficina e tarefas promotoras da orientação temporal dos alunos, procedendo para tal a uma "gestão criteriosa» do Currículo. Curiosamente não houve muitas referências ao uso do Currículo no discurso dos outros docentes e, quando o faziam, identificavam-no com o manual, que tinha grande centralidade nas suas aulas, o que é consentâneo com Afonso ${ }^{28}$.

Sobre a Educação Histórica, o docente do Perfil 7 afirmava que este «é o conhecimento específico que eu devo ter como docente de História, no que diz respeito à didática, e que não tem nada a ver com as noções e os conceitos que tivemos na nossa formação após a licenciatura, na formação profissional». Tal denota a importância da formação contínua para a mudança de práticas, mas esta nem sequer foi referida nas entrevistas dos restantes docentes, que preferiam destacar a influência da formação inicial na sua ação letiva, mesmo com mais de 20 anos de serviço: «[o que faço] é muito da formação inicial [...] e se calhar está um bocado antiquada». A maior parte destes docentes assumiu ainda ter fracos hábitos de leitura sobre inovações pedagógicas e didáticas, não procurando entender os seus pressupostos teóricos e criando «práticas híbridas»: «Não gosto de me apegar a um modelo porque todos eles têm uma parte com que eu concordo e outra que não concordo. Então vou ajustando.»

${ }^{28}$ AFONSO, 2013. 


\section{O COMPROMISSO COM A DIVULGAÇÃO E FORMAÇÃO CONTÍNUA EM EDUCAÇÃO HISTÓRICA}

Depois de tudo o que ficou dito, fácil se torna entender o meu compromisso com a divulgação dos resultados da investigação no meio académico e no meio escolar.

No meio académico passei a ser investigadora integrada do CITCEM, no final de 2017, altura em que também Isabel Barca se juntou a este centro (a que tinha pertencido Isabel Afonso) e onde se encontravam já Helena Pinto e Marília Gago e, mais recentemente, Ana Catarina Simão. Aí fui muito bem acolhida no Grupo de Investigação «Educação e Desafios Societais», coordenado por Luís Alberto Alves, e tenho participado em várias iniciativas e realizado algumas comunicações. Continuo a publicar artigos científicos em revistas nacionais e internacionais, alguns deles relativos à minha participação em eventos científicos como as Jornadas Internacionais de Educação Histórica e a HEIRNET, onde me cruzo com Isabel Barca e onde, sobejas vezes, discutimos com outros investigadores nacionais e internacionais as expetativas de futuro da Educação Histórica.

Ultimamente os meus interesses de investigação em Educação Histórica prendem-se com a orientação temporal dos alunos num mundo em que a diversidade de perspetivas e de informação é crescente e em que se torna premente o desenvolvimento de competências críticas para formar identidades mais humanistas e disponíveis para uma ação consonante com as necessidades deste tempo. Para tal, e seguindo de perto Barca ${ }^{29}$ e Rüsen ${ }^{30}$, criei uma experiência de aprendizagem para o 12. ${ }^{\circ}$ ano em torno das Questões Transnacionais, da qual recolhi dados em 2015 e em 2108 e que estou em fase de análise.

A aposta na formação contínua de professores proveio do facto de esta ter sido o elemento-chave para os melhores desempenhos observados na minha investigação. Assim, e apesar da consciência de que a formação responde sobretudo aos professores interessados em buscar outras formas de fazer aprender ou em aprofundar as suas práticas, tenho desenvolvido formação em Educação Histórica alicerçada na interligação entre investigação, epistemologia e práticas. Como as Aprendizagens Essenciais (AE) e a avaliação formativa construtivista são, neste momento, as maiores preocupações dos professores que têm procurado formação mais ativamente (também devido às oportunidades criadas pelo desbloqueio da progressão na carreira docente), tenho partido desses documentos legais para esclarecer o seu espírito. Nas AE sublinho como a valorização de um núcleo essencial de conceitos e conteúdos permite uma «gestão criteriosa» do currículo. Os docentes, libertos do peso de um currículo extenso, podem criar tarefas promotoras das competências de interpretação e de compreensão, que levem os alunos a olhar para o conhecimento histórico não como algo inerte, mas sim como um processo de construção que tem repercussões nos nossos dias e que, por isso, pode ajudar a construir

\footnotetext{
${ }^{29}$ BARCA, 2015.

${ }^{30}$ RÜSEN, 2015.
} 
cenários de futuro. Nas ações de formação de maior duração desafio ainda os professores para a reflexão epistemológica e para a construção de tarefas onde aliem práticas de avaliação construtivista com práticas de ensino e de aprendizagem que envolvam os alunos na busca da evidência através de um questionamento orientado para a contextualização, a causalidade, a mudança e/ou continuidade ou para a relação passado/presente.

Como balanço final, e mesmo sabendo que nem todos os formandos se vão tornar fervorosos adeptos das práticas da Educação Histórica, não posso deixar de referir que encontrei professores muito motivados para alterar as suas práticas devido ao entusiasmo pelos resultados obtidos, ao lado de outros que vinham «reciclar» e aprofundar o conhecimento nesta área. Pude assim testemunhar que a formação contínua em Educação Histórica, desde a primeira década de 2000, abriu caminhos válidos para alguns professores que estão no terreno e entre os quais se conta o docente do Perfil 7 da minha investigação. Espero que as reflexões desenvolvidas no âmbito da formação contínua ampliem os resultados destes (re)encontros com a Educação Histórica.

\section{BIBLIOGRAFIA}

AFONSO, Isabel (2013) - O papel do manual de História no desenvolvimento de competências: um estudo com professores do ensino secundário. Braga: Universidade do Minho. Tese de doutoramento.

ASHBY, Rosalyn; LEE, Peter (1987) - Children's concepts of empathy and understanding in history. In PORTAL, Christopher, ed. - The history curriculum for teachers. London: The Falmer Press. p. 62-88.

ASHBY, Rosalyn; LEE, Peter; SHEMILT, Denis (2005) - Putting principles into practice: teaching and planning. In DONOVAN, Marie; BRANSFORD, John D., eds. - How students learn: History, Mathematics and Science in the classroom. Washington D. C.: The National Academies Press, p. 79-178.

BARCA, Isabel (2000) - O Pensamento Histórico dos Jovens: Ideias dos Adolescentes acerca da Provisoriedade da Explicação Histórica. Braga: CEEP/Universidade do Minho.

(2004) - Aula Oficina: do Projecto à Avaliação. In BARCA, Isabel, org. - Para uma Educação Histórica com Qualidade: Actas das IV Jornadas Internacionais de Educação Histórica. Braga: CIEd/Universidade do Minho; Instituto de Educação e Psicologia/Universidade do Minho, p. 131-144.

(2015) - History and temporal orientation: the views of Portuguese-speaking students. In CHAPMAN, Arthur; WILSCHUT Arie, ed. - Joined-Up History - new directions in Education History Research. Charlotte, NC: IAP, p. 15-35.

COOPER, Hilary; CHAPMAN, Arthur (2009) - Constructing history 11-19. London: SAGE.

CORBIN, Juliet; STRAUSS, Anselm (2008) - Basics of qualitative research. Techniques and procedures for Developing Grounded Theory. Thousand Oaks, CA: SAGE.

FERNANDES, Domingos (2005) - Avaliação das aprendizagens: desafios às teorias, práticas e políticas. Cacém: Texto Editora.

GAGO, Marília (2007) - Consciência histórica e narrativa na aula de História: concepções de professores. Braga: Universidade do Minho. Tese de doutoramento.

HARLEN, Wynne (2006) - On the Relationship between Assessment for Formative and Summative Purposes. In GARDNER, John, ed. - Assessment and Learning. London: SAGE, p. 103-117.

LAGARTO, Mariana (2009) - Avaliação Formativa e exames nacionais: análise de práticas de ensino e avaliação de uma professora da disciplina de História. Lisboa: Faculdade de Psicologia e Ciências da Educação. Dissertação de mestrado. 
(2017) - Desenvolver e avaliar competências em História: um estudo com professores do $3 .^{\circ}$ ciclo do ensino básico. Braga: Universidade do Minho. Tese de doutoramento.

LEE, Peter (2005) - Putting principles into practice: understanding History. In DONOVAN, M. Suzanne; BRANSFORD, John D., eds. - How students learn: History, Mathematics and Science in the classroom. Washington, D. C.: The National Academies Press, p. 31-78.

LEE, Peter; ASHBY, Rosalyn; DICKINSON, Alaric (1993) - Progression in Children's Ideas about History. Project CHATA (Concepts of History and Teaching Approaches: 7 to 14). Draft. Disponível em $<$ https:// eric.ed.gov/?q=peter+lee+chata\&id=ED388531> [Consulta realizada em 23/07/2014].

LEE, Peter; SHEMILT, Denis (2003) - A scaffold, not a cage: progression and progression models in history. «Teaching History», n.o 113, p. 13-23. Disponível em <https://pt.scribd.com/document/238794367/ Lee-y-Shemilt-A-scaffold-not-a-cage> [Consulta realizada em 26/06/2014].

PORTUGAL. Direcção-Geral do Ensino Básico (2001) - Currículo Nacional do Ensino Básico - Competências Essenciais. Lisboa: DEB.

ROLDÃO, Maria do Céu (2003) - Gestão do Currículo e avaliação de competências - as questões dos professores. Lisboa: Editorial Presença.

RÜSEN, Jörn (2001) - Razão histórica. Brasília: Editora da Universidade de Brasília. (2015) - Humanismo na era da globalização: ideias sobre uma nova orientação cultural. In RÜSEN, Jörn - Humanismo e Didática da História. Org. Maria Auxiliadora Schmidt et al. Curitiba: W. A. Editores, p. 153-161.

SHEMILT, Denis (1980) - History 13-16: Evaluation Study. Edinburgh: Holmes McDougall.

SEIXAS, Peter (2015) - Looking for History. In CHAPMAN, Arthur; WILSCHUT, Arie, ed. - Joined-Up History - new directions in Education History Research. Charlotte, NC: IAP, p. 255-276.

SEIXAS, Peter; PECK, Carla (2004) - Teaching historical thinking. In SEARS, Alan; WRIGHT, Ian, eds. Challenges and prospects for Canadian Social Studies. Vancouver: Pacific Educational Press, p. 109-117. 


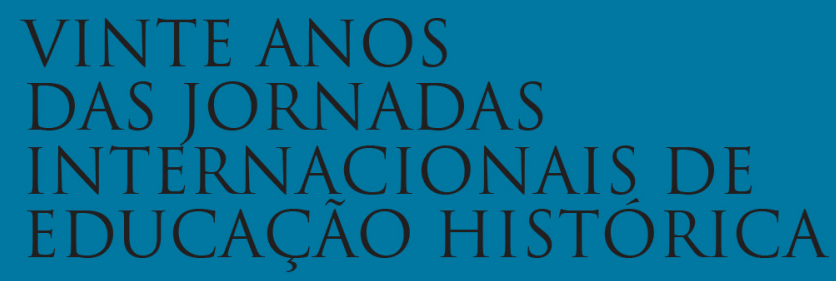

\section{COORD.}

LUIIS ALBERTO MARQUES ALVES

MARÍLIA GAGO

MARIANA LAGARTO 